\author{
UNIVERSIDADE DE SÃO PAULO \\ FACULDADE DE FILOSOFIA, LETRAS E CIÊNCIAS HUMANAS \\ DEPARTAMENTO DE GEOGRAFIA \\ PROGRAMA DE PÓS-GRADUAÇÃO EM GEOGRAFIA FÍSICA
}

\title{
Mineração e preservação ambiental na área natural tombada da Serra do Boturuna, Estado de São Paulo
}

Sandro Francisco Detoni

Dissertação apresentada ao Programa de Pós-Graduação em Geografia Física do Departamento de Geografia da Faculdade de Filosofia, Letras e Ciências Humanas da Universidade de São Paulo, para a obtenção do título de mestre em Ciências. Área de Concentração: Geografia Física

Orientador: Prof. Dr. Yuri Tavares Rocha

São Paulo 2008 


\section{FOLHA DE APROVAÇÃO}

Sandro Francisco Detoni

Mineração e preservação ambiental na área

natural tombada da Serra do Boturuna,

Estado de São Paulo

Dissertação apresentada à Faculdade de Filosofia, Letras

e Ciências Humanas da Universidade de São Paulo para a obtenção do título de Mestre.

Área de Concentração: Geografia Física

Aprovado em:

Banca examinadora

Prof. Dr.

Instituição:

Assinatura:

Prof. Dr.

Instituição:

Assinatura: 


\section{AGRADECIMENTOS}

À Universidade de São Paulo por propiciar as condições necessárias à realização da pesquisa.

Ao Departamento de Geografia, seus professores e seus funcionários que, de forma direta ou indireta, contribuíram para a realização deste trabalho.

Ao Prof. Dr. Yuri Tavares Rocha pela amizade, pela orientação e pelo apoio no decorrer da pesquisa.

Ao Conselho Nacional de Desenvolvimento Cientifico e Tecnológico pela a concessão da bolsa de mestrado.

À Empresa Paulista de Planejamento Metropolitano por disponibilizar importantes dados para a pesquisa.

À Prof. Dra. Ana Marangoni e ao Prof. Dr. Jurandyr Luciano Sanches Ross pelas importantes sugestões no exame de qualificação.

Ao engenheiro de minas Prof. Dr. Marco Antonio Rezende Silva por sua importante contribuição na pesquisa.

Ao Oscar Bras Berreta Pion da Empresa Metropolitana de Águas e Energia por disponibilizar os dados climatológicos.

Aos professores Emerson, Ailton, Raffo e Déborah pelas diversas contribuições no decorrer da pesquisa.

Ao Odair Nigosky da Secretaria de Estado do Meio Ambiente de São Paulo por disponibilizar dados referentes ao ICMS.

Ao Departamento de Avaliação de Impacto Ambiental da Secretaria de Estado de Meio Ambiente de São Paulo por permitir o acesso aos PRADs e pela atenção de seus funcionários.

À geógrafa Lídia do Instituto Geológico por fornecer material de apoio.

À geógrafa Cleide Polleto por suas sugestões e por sua ajuda com os Planos Diretores de Mineração.

Ao coordenador de meio ambiente da Prefeitura de Pirapora do Bom Jesus, Ailton Paulo Pinto, por sanar minhas dúvidas sobre a estrutura administrativa do município.

À minha família, principalmente minha mãe, Maria de Lourdes Detoni, e todos meus familiares no Interior de São Paulo, nos quais sempre tenho prazer pela companhia, porém, o meu envolvimento com a pesquisa fez com que eu ficasse um pouco distante.

A todos meus amigos, em especial aos que estiveram mais próximo neste momento: Marcão, Tatiana, Brunão, Eric, Rita, Paula, lgor, Andressa, Claudiomiro, Stella, Marquinho, Kelly, Rúbia, Fernando, Vanderlei, Flório, Xicko. Aos meus amigos no CRUSP: Ailton, Flávio, Fabiana, Kelly, Leila, Luciano, Luís, Luciana, Márcia, Jader, Vítor, Roberto, Suene.

Provavelmente, faltam muitas pessoas que compartilharam diversos momentos bons comigo, porém, desejo a todos meus sinceros agradecimentos. 
"Ai seu moço, eu só quiria... Vara de anzó, pôca mángua, Pinga boa e bão café... Fumo forte de sobejo, P'ra compretá meu desejo, Cavalo bão - e muié..."

Cornélio Pires (1884 - 1958), Poeta Paulista de Qualidade 


\section{RESUMO}

DETONI, S. F. Mineração e preservação ambiental na área natural tombada da Serra do Boturuna, Estado de São Paulo. 2008. 252 f. Dissertação (Mestrado) - Faculdade de Filosofia, Letras e Ciências Humanas da Universidade de São Paulo, São Paulo, 2008.

O tombamento de áreas naturais constitui-se num importante instrumento jurídico de proteção aos remanescentes florestais e às paisagens de destaque do Estado de São Paulo. Esse pressuposto permitiu o estabelecimento da Área Natural Tombada (ANT) da Serra do Boturuna, localizada próxima à Capital Paulista. Sua estrutura geomorfológica diferenciada a destaca na paisagem regional, juntamente com os atributos vegetacionais. Os remanescentes florestais e a frágil estrutura paisagística da região justificaram a criação da ANT pelo Conselho de Defesa do Patrimônio Histórico, Arqueológico, Artístico e Turístico do Estado de São Paulo (CONDEPHAAT). Na ocasião do tombamento, a principal atividade econômica na Serra relacionava-se à exploração minerária. Apesar do parecer técnico desfavorável a essa atividade, a resolução de tombamento optou por manter as mineradoras no perímetro de tombamento. Entretanto, tal ato constitui-se numa contradição no âmbito da jurisprudência do tombamento. Este trabalho analisou as razões ambientais favoráveis ao tombamento e a eficácia desse instrumento de preservação; a importância mineral da Serra do Boturuna e as propostas de recuperação descritas nos Planos de Recuperação de Áreas Degradadas (PRADs) das mineradoras que atuam na região da Serra. Ao avaliar os principais atributos que conduziram ao tombamento da Serra, é possível afirmar que o ato do tombamento justifica a importância ambiental da região. A análise dos dados sobre a cobertura vegetal demonstrou que o tombamento foi eficaz para a preservação e o restabelecimento da cobertura florestal na área tombada. Porém, o impacto sobre o relevo, fruto da exploração minerária, interfere em outros objetivos do tombamento. O estágio atual da atividade e os métodos de lavra empregados comprometem um dos principais atributos que conduziram ao tombamento da Serra, a topografia. As propostas de recuperação topográfica, dificilmente, atribuirão um padrão paisagístico aceitável para as áreas mineradas na ANT. Porém, alguns PRADs pressupõem que a mineração contribuirá para a recuperação ambiental da região, em virtude do incremento de cobertura vegetal com espécies nativas numa área já degradada. Essa ênfase minimiza os efeitos da alteração topográfica e descaracteriza um dos principais fundamentos do tombamento: a preservação do relevo. Diante dessas características, a preservação ambiental da Serra deve pressupor ações de planejamento e de controle sobre a atividade de exploração mineral.

Palavras-chave: Serra do Boturuna; Área Natural Tombada; Mineração; Paisagem; Preservação Ambiental 


\begin{abstract}
DETONI, S. F. Mining and environment preservation in mountain range of Boturuna nature heritage area, in São Paulo State. 2008. 252 f. Dissertação (Mestrado) - Faculdade de Filosofia, Letras e Ciências Humanas da Universidade de São Paulo, São Paulo, 2008.

The creation of nature heritage area is a lawful form to protect the forest remainders and the landscapes Theses attributes helped to consider the mountain range of Boturuna, in São Paulo State, as a nature heritage. Its geomorphology structure and its vegetation are the condition to prominent of the mountain in the regional landscape. The forest remainders and the landscape structure fragile justified the creation this nature heritage by Conselho de Defesa do Patrimônio Histórico, Arqueológico, Artístico e Turístico do Estado de São Paulo (CONDEPHAAT). When the area was protected, the economic activity main was the mineral exploration. The technical opinion was unfavorable to this activity, by the law opted to maintain the mine companies in the protection area. In the meantime, this is a contradiction in the law. This work analyzed the favorable environment aspects to the establishment this nature heritage area, what was the efficiency this preservation instrument, the importance the mine activity in the mountain, and the suggestions the assessment of mine reclamation procedures. The attributes to the establishment this nature heritage justify the environment importance of region. The action to protect the area was efficient and helped the preservation and the vegetation cover restoration. However, the alteration on relief due to exploration activity mine created interferences in the protection objectives. The exploration methods caused a great deal of damage in the mountain topographic. Some recuperation planes describe that mine exploration will contribute to recuperation of the area, because will contribute to increase in vegetation cover with native species. It affirmation reduce the importance of topographic alteration cause by exploration mine. The mountain range preservation depends on planning actions and miner exploration control.
\end{abstract}

Key-words: Boturuna mountain range; nature heritage; mine; landscape; environment preservation 


\section{LISTA DE MAPAS}

Mapa 1 - Localização da ANT da Serra do Boturuna, Estado de São Paulo 20

Mapa 2 - Espaços Territoriais Especialmente Protegidos: Pirapora do Bom Jesus e Santana de Parnaíba, Estado de São Paulo 39

Mapa 3 - Precipitação Média Anual (1972 a 2002) na Região da ANT da Serra do Boturuna, Estado de São Paulo 52 Mapa 4 -Uso e Ocupação do Solo (1986) na ANT da Serra do Boturuna, Estado de São Paulo

Mapa 5 -Uso e Ocupação do Solo (2002) na ANT da Serra do Boturuna, Estado de São Paulo

Mapa 6 -Geológico de Pirapora do Bom Jesus e de Santana de Parnaíba, Estado de São Paulo

Contexto Hipsométrico Regional da Serra do Boturuna, Estado de São Paulo

Mapa 8 - Hipsométrico da ANT da Serra do Boturuna, Estado de São Paulo __ 101

Mapa 9 - Orientação do Perfil Topográfico 102

Mapa 10 - Clinográfico da ANT da Serra do Boturuna, Estado de São Paulo __ 104

Mapa 11 - Distribuição das Unidades Litoestruturais do Estado de São Paulo __ 110

Mapa 12 - Distribuição Espacial dos Processos no DNPM na Fase de Concessão de Lavra:

Pirapora do Bom Jesus e Santana de Parnaíba, Estado de São Paulo __ 149

Mapa 13 -Poligonais Minerárias na Região da ANT da Serra do Boturuna, Estado de São Paulo

152

Mapa 14 - Mineração Lolli Extrativa de Minerais Ltda. - Imagem Ortorretificada (2002) e

Poligonais Minerárias _ 170

Mapa 15 - Minarca Indústria, Comércio e Mineração Ltda. - Imagem Ortorretificada (2002) e

Poligonal Minerária__ 193

Mapa 16 - Saint-Gobain Argamassas Quartzolit/Hipermix Concreto - Imagem Ortorretificada (2002) e Poligonais Minerárias 207

Mapa 17 -Mineração Armando Angelini - Imagem Ortorretificada (2002) e Poligonais Minerárias

\section{LISTA DE FIGURAS}

Figura 1 -Vertentes da Serra do Boturuna no município de Santana de Parnaíba - SP: Destaque para os remanescentes florestais

Figura 2 -Vertentes da Serra do Boturuna no município de Pirapora do Bom Jesus - SP: destaque para as áreas de mineração e a área do parque industrial em primeiro plano, à direita

Figura 3 -Climatograma da estação pluviométrica de Pirapora (P12-237), série histórica de 30

$\begin{array}{lllllll}1957 \text { a } 2005 & & & & & \\ \text { Figura } 4 \text {-Gradiente } & \text { vegetacional da } & \text { região da } & \text { Serra do Boturuna }\end{array}$

Figura 5 -Bowdichia virgilioides (Leguminosae-Papilionoideae) no topo da Serra do Boturuna

61

Figura 6 -Área do parque industrial: à direita, em segundo plano, a Serra do Boturuna e o componente marcante na paisagem, a mineração

Figura 7 -Coluna estratigráfica esquemática do Sinclinório de Pirapora

82

94

Figura 8 -Estrutura laminar e seqüência rítmica do embasamento quartzítico da Serra do

Boturuna _ 95

Figura 9 - Serra do Boturuna: relevo de destaque na paisagem regional ___ 102

Figura 10 - Perfil topográfico esquemático da região da Serra do Boturuna __ 103

Figura 11 - Frente de mineração lavrada pela CCBE, abandonada e não recuperada _ 190

Figura 12 - Avanço da frente de lavra de quartzito: Processo DNPM n. 2.792/48__ 191

Figura 13 - Aspecto geral da frente de lavra 1, observam-se sedimentos inconsolidados que podem ser conduzidos para a rede de drenagem 200

Figura 14 -Frente de lavra 3: as propostas de reconfiguração topográfica não foram efetuadas 
Figura 15 - Limite oeste da poligonal minerária da Minarca: frentes de lavras exploradas pela Mineração Armando Angelini 203

Figura 16 - ANT da Serra do Boturuna: frentes de lavra na propriedade da Quartzolit (Processo DNPM n. 820.457/1979), à esquerda; frentes de lavras abandonadas da antiga Mineração Mar Paulista, à direita 206

Figura 17 - Mineração Dois Irmãos em 1982 (Processo de tombamento da Serra do Boturuna - CONDEPHAAT n. 22328/82

Figura 18 - Aspecto atual da antiga Mineração Dois Irmãos 209

Outro ângulo do aspecto atual da antiga Mineracão Dois Irmãos

Figura 20 - Organograma do processo de extração mineral 231

Figura 21 - Cava A da Mineração Armando Angelini 236

\section{LISTA DE TABELAS}

Tabela 1 - Evolução da população residente em Santana de Parnaíba - SP _ 26 Tabela 2 - Evolução da população residente em Pirapora do Bom Jesus - SP_ 32

Tabela 3 - Áreas dos municípios e dos espaços territoriais especialmente protegidos 38 Tabela 4 - Distribuição dos espaços territoriais especialmente protegidos em Pirapora do Bom Jesus - SP e em Santana de Parnaíba - SP

Tabela 5 - Abrangência dos espaços territoriais especialmente protegidos em Pirapora do Bom Jesus - SP e em Santana de Parnaíba - SP 42 Tabela 6 - Médias históricas (1972 a 2002) das estações pluviométricas da região da Serra do Boturuna, Estado de São Paulo

Tabela 7 - Uso e ocupação do solo e cobertura vegetal (1986) na ANT da Serra do Boturuna e zona de amortecimento

Tabela 8 - Uso e ocupação do solo e cobertura vegetal (2002) na ANT da Serra do Boturuna e zona de amortecimento

Tabela 9 - Distribuição quantitativa das antigas frentes de lavras identificadas por categorias de uso e ocupação do solo (2002) na ANT da Serra do Boturuna.

Tabela 10 - Abrangência das unidades litológicas 90

Tabela 11 - Distribuição espacial das principais rochas do Grupo São Roque em Pirapora do Bom Jesus e Santana de Parnaíba, Estado de São Paulo 90 Tabela 12 -Distribuição quantitativa das classes clinográficas na ANT da Serra do Boturuna

Tabela 13 -Maiores participações nas operações minerais do Estado de São Paulo (2006)

Tabela 14 -Participação do Estado de São Paulo na produção de alguns bens não metálico (2005) 112 Tabela 15 - Porcentagem de participação da RMSP na produção mineral do Estado de São Paulo (2004 a 2006) 113

Tabela 16 - Porcentagem de participação da produção mineral de Pirapora do Bom Jesus na RMSP (1981)

Tabela 17 - Alíquotas da CFEM

120

Tabela 18 - Distribuição dos recursos provenientes da CFEM __ 129

Tabela 19 - Distribuição dos recursos provenientes do IUM 130

Tabela 20 - Participação do IUM (1975 a 1980) na composição da receita do município de

Pirapora do Bom Jesus - SP 132

Tabela 21 - Participação do CFEM na composição da receita do município de Pirapora do Bom Jesus - SP (1999 a 2005) 134

Tabela 22 - Participação do CFEM na composição da receita do município de Santana de Parnaíba - SP (1999 a 2005) 135

Tabela 23 - Percentuais de repasse de ICMS conforme Lei Estadual n. 8.510/93___ 138

Tabela 24 - Índices de ponderação conforme Lei Estadual n. 8.510/95 139

Tabela 25 - Participação do ICMS ecológico na composição da receita do município de Pirapora do Bom Jesus - SP (1999 a 2005) 143

Tabela 26 - Participação do ICMS ecológico na composição da receita do município de Santana de Parnaíba - SP (1999 a 2005) 143

Tabela 27 - Poligonais minerárias dos municípios de Pirapora do Bom Jesus e Santana de Parnaíba, Estado de São Paulo 146

Tabela 28 - Abrangência das poligonais minerárias 146 
Tabela 29 - Substância mineral e fase do processo minerário 147

Tabela 30 - Concessão de lavra nos municípios de Pirapora do Bom Jesus e Santana de Parnaíba, Estado de São Paulo 150

Tabela 31 - Poligonais minerárias sob regime de concessão de lavra na Serra do Boturuna, Estado de São Paulo 153

Tabela 32 - Participação nas operações minerais de quartzito industrial e friável (Produção estimada conforme recolhimento do CFEM) 159

Tabela 33 - Evolução das reservas de areia industrial, quartzito industrial e quartzito ornamental em Pirapora do Bom Jesus - SP (2001 a 2005) 160 Tabela 34 - Participação nas operações minerais de filito (Produção estimada conforme recolhimento do CFEM) 163

Tabela 35 - Principais municípios na participação das operações minerais de filito no Estado de São Paulo (2006) 164

Tabela 36 - Participação nas operações minerais de calcário dolomítico e dolomito (Produção estimada conforme o recolhimento do CFEM) 167 Tabela 37 - Reserva de leucofilito (filito) no Sítio Itaqueri 192

Tabela 38 - Mineração Armando Angelini: reservas laváveis medidas/indicadas In Situ* 233

\section{LISTA DE QUADROS}

Quadro 1 - Classes de Uso e Ocupação do Solo do Mapeamento de 1986 65

Quadro 2 - Folhas geológicas utilizadas na elaboração do mapa geológico 84

Quadro 3 - Coluna estratigráfica da região da Serra do Boturuna___ 89

Quadro 4 - Litologias predominantes no perfil topográfico _ _ 103

Quadro 5 - Atribuições dos órgãos executores __ 116

Quadro 6 - Procedimentos técnico-institucionais para as áreas de mineração permitida com restricões do CONDEPHAAT

Quadro 7 - Substâncias por grupo 158

Quadro 8 - Substâncias por grupo $\quad 162$

Quadro 9 - Substâncias por grupo __ 166

Quadro 10 - Cronograma das Atividades da Recuperação da Área Degradada___ 201

\section{LISTA DE GRÁFICOS}

Gráfico 1 - Distribuição quantitativa das classes de uso e ocupação do solo na ANT da Serra do Boturuna (1986 a 2002)

Gráfico 2 - Distribuição quantitativa das classes de uso e ocupação do solo na ANT da Serra do Boturuna, em Pirapora do Bom Jesus - SP (1986 a 2002) 77 Gráfico 3 - Distribuição quantitativa das classes de uso e ocupação do solo na ANT da Serra do Boturuna, em Santana de Parnaíba - SP (1986 a 2002) 79 Gráfico 4 - Distribuição quantitativa das classes de uso e ocupação do solo na ANT da Serra do Boturuna, em Araçariguama - SP (1986 a 2002) 80 Gráfico 5 - Evolução da participação do CFEM e do ICMS ecológico na composição da receita de Pirapora do Bom Jesus - SP (1999 a 2005)___ 144 Gráfico 6 - Evolução da participação do CFEM e do ICMS ecológico na composição da receita de Santana de Parnaíba - SP (1999 a 2005) 145 


\section{LISTA DE SIGLAS}

ANT - Área Natural Tombada

APA - Área de Proteção Ambiental

APP - Área de Preservação Permanente

CCBE - Companhia Construtora Brasileira de Estradas

CETESB - Companhia de Tecnologia de Saneamento Ambiental do Estado de São Paulo

CFEM - Compensação Financeira pela Exploração dos Recursos Minerais

COBRAMI - Companhia Brasileira de Mineração

COMGE - Companhia de Mineração Geral

CONAMA - Conselho Nacional de Meio Ambiente

CONDEPHAAT - Conselho de Defesa do Patrimônio Histórico, Arqueológico e Turístico do

Estado de São Paulo

CONSEMA - Conselho Estadual de Meio Ambiente

COSIPA - Companhia Siderúrgica Paulista

CPRM - Companhia de Pesquisa dos Recursos Minerais

DAIA - Departamento de Avaliação de Impacto Ambiental

DEPRN - Departamento Estadual de Proteção de Recursos Naturais

DER - Departamento de Estradas de Rodagem do Estado de São Paulo

DNPM - Departamento Nacional de Produção Mineral

EIA - Estudo de Impacto Ambiental

EMAE - Empresa Metropolitana de Águas e Energia S.A

EMPLASA - Empresa Paulista de Planejamento Metropolitano S. A.

FIPE - Fundação Instituto de Pesquisas Econômicas

FPA - Frente Polar Atlântica

IBGE - Instituto Brasileiro de Geografia e Estatística

ICMS - Imposto Sobre Circulação de Mercadorias e Serviços

IPT - Instituto de Pesquisas Tecnológicas do Estado de São Paulo

IUM - Imposto Único sobre Minerais

MPA - Massa Polar Atlântica

MTA - Massa Tropical Atlântica

MTC - Massa Tropical Continental

PAE - Plano de Aproveitamento Econômico

PCA - Plano de Controle Ambiental

PDM - Plano Diretor de Mineração

PL - Plano de Lavra

PRAD - Plano de Recuperação de Áreas Degradadas

PROSIG - Cadastro Mineral do Sistema de Dados Essenciais sobre Atividade Mineral

RAL - Relatório Anual de Lavra

RCA - Relatório de Controle Ambiental

RAP - Relatório Ambiental Preliminar

RIMA - Relatório de Impacto Ambiental

RMSP - Região Metropolitana de São Paulo

SC - Secretaria de Estado da Cultura

SCM - Sistema Cartográfico Metropolitano

SEADE - Fundação Estadual de Análise de Dados

SIG - Sistema de Informação Geográfica

SISMINE - Sistema de Gestão da Produção Mineral

SMA - Secretaria de Estado do Meio Ambiente de São Paulo

SNM - Secretaria de Estado dos Negócios Metropolitanos

SNUC - Sistema Nacional de Unidades de Conservação

TGCA - Taxa Geométrica de Crescimento Anual

UNESCO - United Nations Educational, Scientific and Cultural Organization

VAF - Valor Adicionado Fiscal

ZEE - Zoneamento Ecológico-Econômico

ZUPI - Zona de Uso Predominante Industrial

ZVS - Zona de Vida Silvestre 
1 INTRODUÇÃO 13

2 OBJETIVOS 17

3 LOCALIZAÇÃo E CARACTERÍSTICAS GERAIS DA ÁREA DE ESTUDO 18

3.1 SERRA DO BOTURUNA 18

3.2 SANTANA DE PARNAÍBA 21

3.3 PIRAPORA DO BOM JESUS 27

4 PAISAGEM E TEORIA GERAL DOS SISTEMAS 32

5 ESPAÇOS TERRITORIAIS ESPECIALMENTE PROTEGIDOS 38

5.1 CONTEXTO MUNICIPAL 38

5.2 ÁREA NATURAL TOMBADA 42

5.3 TOMBAMENTO DA SERRA DO BOTURUNA 46

6 ASPECTOS CLIMÁTICOS DA REGIÃO 49

7 SOLOS NA ANT DA SERRA DO BOTURUNA 53

8 VEGETAÇÃO NA ANT DA SERRA DO BOTURUNA 56

9 USO E OCUPAÇÃO DO SOLO NA ANT DA SERRA DO BOTURUNA E ZONA DE AMORTECIMENTO DE 300M 64

$9.1 \quad$ EM 1986 64

9.2 EM 2002 72

10 CARACTERIZAÇÃO GEOLÓGICA 84

10.1 CONTEXTO GEOLÓGICO REGIONAL 84

10.2 ASPECTOS GEOLÓGICOS DA SERRA DO BOTURUNA 92

11 CARACTERIZAÇÃO E ANÁLISE GEOMORFOLÓGICA 95 11.1 SERRA DO BOTURUNA E O CONTEXTO GEOMORFOLÓGICO REGIONAL 95

11.2 QUESTÃO DOS NÍVEIS DE APLAINAMENTO 105

12 O CONTEXTO MINERÁRIO 108 
12.1 MINERAÇÃO NO ESTADO DE SÃO PAULO 108

12.2 EXPLORAÇÃO MINERAL NA RMSP 112

12.3 CÓDIGO DE MINERAÇÃO E LICENCIAMENTO AMBIENTAL 124

13 TERRITÓRIO E POLÍTICA AMBIENTAL 135

13.1 LEI ESTADUAL N. 8.510/93 - ICMS ECOLÓGICO 137

13.2 COMPARAÇÃO ENTRE ICMS ECOLÓGICO E A CFEM 144

14 QUADRO ATUAL DA MINERAÇÃO EM PIRAPORA DO BOM JESUS E SANTANA DE PARNAÍBA 145

14.1 MINERAÇÃO NA SERRA DO BOTURUNA 151

15 RECUPERAÇÃO DAS ÁREAS DEGRADADAS POR MINERAÇÕES 167

15.1 LOLLI EXTRATIVA DE MINERAIS LTDA. 169

15.2 MINARCA INDÚSTRIA, COMÉRCIO E MINERAÇÃO LTDA. 191

15.3 MINERAÇÃO ARGAMASSAS QUARTZOLIT LTDA. 204

15.4 MINERAÇÃO ARMANDO ANGELINI 228

16 CONSIDERAÇÕES FINAIS 241 REFERÊNCIAS 246 ANEXOS 
A preservação ${ }^{1}$ de remanescentes florestais no Estado de São Paulo inicia-se de forma legal no final da década de 1930 por meio do Decreto Estadual n. 10.877 de 30/11/1939 (substituído pelo Decreto Estadual n. 38.391 de 03/05/1961), que criou o Parque Estadual do Jaraguá. A partir daí, propuseram-se outros importantes parques, entre os quais, o Parque Estadual de Campos do Jordão (1940), o Parque Estadual da Cantareira (1963) e o Parque Estadual Fontes do Ipiranga (1969).

Apesar da criação de diversos e de distintos espaços para a proteção da natureza, a questão ambiental no Estado de São Paulo ganhou maior enfoque no final da década de 1970 e em meados dos anos de 1980. Nesse período, foram discutidos e estabelecidos os instrumentos legais, juntamente com a estrutura estatal, para garantir de forma institucional a preservação ambiental e o controle da poluição no Estado.

$\mathrm{Na}$ década de 1980, a questão da preservação e da conservação ${ }^{2}$ ambiental se manifestou de forma sem precedentes. Tornou-se necessário a revisão de determinadas posturas sobre a exploração dos recursos naturais e sobre a poluição nas mais distintas formas. Problemas ambientais como os ocorridos em Cubatão, no litoral Paulista, demonstraram o descaso com as questões relacionadas à conservação e a garantia da mínima qualidade ambiental. Esse descaso ficou claramente exposto na paisagem da Serra do Mar e nos níveis de poluição industrial daquela região do Estado.

Em 1983, foi criado o Conselho Estadual de Meio Ambiente (CONSEMA), sendo um conselho misto com representantes de todos os

\footnotetext{
${ }^{1}$ Utilizou-se o termo preservação conforme descrito no inciso V da Lei Federal n. 9.985/2000 que estabeleceu o Sistema Nacional de Unidades de Conservação: a preservação ambiental configura-se como o "conjunto de métodos, procedimentos e políticas que visem a proteção a longo prazo das espécies, hábitats e ecossistemas, além da manutenção dos processo ecológico, prevenindo a simplificação dos sistemas naturais."

${ }^{2}$ Utilizou-se o termo conservação conforme descrito no inciso V da Lei Federal n. 9.985/2000 que estabeleceu o Sistema Nacional de Unidades de Conservação: a conservação da natureza envolve "o manejo do uso humano da natureza, compreendendo a preservação, a manutenção, a utilização sustentável, a restauração e a recuperação do ambiente natural, para que possa produzir o maior benefício, em bases sustentáveis, às atuais gerações, mantendo seu potencial de satisfazer as necessidades e aspirações das gerações futuras, e garantindo a sobrevivência dos seres vivos em geral."
} 
órgãos do governo e da sociedade civil que estavam relacionados à questão ambiental. Esse órgão, entre outras atribuições, foi responsável por uma política estadual de meio ambiente. Nesse contexto, com a estruturação de uma política ambiental no Estado, em 1986, de forma pioneira, é criada a Secretaria de Estado do Meio Ambiente (SMA), juntamente com o Sistema Estadual de Meio Ambiente por meio do Decreto Estadual n. 24.932/86. No entanto, antes da elaboração das diretrizes básicas que nortearam 0 estabelecimento das políticas de preservação ambiental no Estado, um dos principais instrumentos jurídicos partiu da Secretaria de Estado da Cultura (SC) por meio do Conselho de Defesa do Patrimônio Histórico, Arqueológico e Turístico do Estado de São Paulo (CONDEPHAAT). Esse órgão estatal utilizou como instrumento legal para a preservação ambiental e cultural o princípio da criação das Áreas Naturais Tombadas (ANTs), ou seja, o tombamento de áreas com relevante interesse ambiental e paisagístico. Destaca-se assim, como um importante ícone desse instrumento de preservação, o tombamento natural da Serra do Mar no Estado de São Paulo.

Apesar da saturação ambiental da Mata Atlântica na região da Serra do Mar ter se manifestado na década de 1980, a base jurídica fundamental para a preservação e a conservação dessa importante reserva florestal surgiu, inicialmente, com a criação do Parque Estadual da Serra do Mar em 1977. Logo, outra importante iniciativa para a sua preservação partiu do CONDEPHAAT com a abertura de seu processo de tombamento, em 1979. O tombamento da Serra do Mar significou a preservação de um dos principais remanescentes florestais contínuos do planeta, juntamente com seu reconhecimento cultural e ambiental.

O CONDEPHAAT passou, assim, a se destacar e a possuir um importante papel na preservação ambiental no Estado de São Paulo. Deve-se destacar que esse órgão havia iniciado esse papel em 1972, por meio do tombamento da Paisagem Envoltória do Caminho do Mar.

Aos poucos, o instrumento jurídico ambiental do tombamento adquiriu força e outras áreas foram tombadas. Sua principal importância estava na relação entre o meio ambiente e a cultura. Assim, além do tombamento de áreas naturais, passam a ser tombados também bairros que possuíssem importância ambiental e cultural. 
Sem dúvida alguma, a principal vantagem do tombamento consiste em garantir a preservação sem a desocupação da área e a posterior indenização, ou seja, o tombamento, sobretudo, o de áreas naturais, não onera o Estado, pois não predispõe desapropriações e indenizações. O principal enfoque do tombamento está na regulação do uso e ocupação do solo $^{3}$, logo, qualquer intervenção na área tombada deve ser submetida à análise do CONDEPHAAT. Contudo, para a eficácia desse instrumento de preservação, tornava-se necessário aperfeiçoar as formas de fiscalização e regulação do uso e ocupação do solo.

Com o propósito da preservação ambiental, paisagística, turística e cultural, diversas e importantes áreas naturais tombadas foram criadas, entre outras, a Área Natural Tombada da Serra do Boturuna.

Pode-se afirmar que essa ANT constitui-se num importante patrimônio ambiental do Planalto Atlântico, em virtude de sua diversidade paisagística, importância histórica e cultural. Apesar de amplo desmatamento, destacam-se na região alguns núcleos com cobertura florestal preservada. $O$ relevo, a litologia, o clima, o solo e a vegetação condicionam determinados padrões de distribuição de unidades paisagísticas de significativa importância ambiental.

Com relação à importância histórica, deve-se mencionar que na região da Serra do Boturuna e na do Morro Jaraguá registram-se as primeiras áreas de mineração de ouro de aluvião do território Paulista. As minerações de ouro, nessas regiões contribuíram para o estabelecimento dos primeiros povoados da então Província de São Paulo. De certa forma, o ouro também estimularia as monções dos Bandeirantes Paulistas para desbravar o sertão, à procura de distintos recursos minerais.

No aspecto paisagístico, a Serra do Boturuna destaca-se como um padrão geomorfológico diferenciado no Planalto Atlântico, sendo um marco na paisagem regional, tanto que sua representação está presente nos brasões municipais de Pirapora do Bom Jesus e Araçariguama (Anexos).

A geomorfologia da região, segundo propõe o Professor Dr. Aziz Nacib Ab'Sáber, pode fornecer um importante testemunho das fases erosivas

\footnotetext{
${ }^{3}$ Seria mais adequado utilizar o termo terra. Porém, optou-se pelo termo solo, segundo a terminologia adotada pela EMPLASA em seus mapeamentos.
} 
ocorridas no Planalto Atlântico. O Boturuna, a Serra do Japi, o Pico do Jaraguá e outros morros com embasamento litológico composto por quartzítico, são responsáveis pelas maiores altitudes da região, logo, se diferenciam na paisagem regional.

O embasamento litológico diferenciado, produto de uma história geológica peculiar, também condiciona a distribuição dos solos na Serra da Boturuna, cujas características influenciam diretamente na distribuição dos tipos florestais. Pode-se notar um padrão de distribuição florestal relacionado, principalmente, à altitude e à estrutura pedológica. Verificam-se assim padrões fitofisionômicos muito semelhantes ao do cerrado, o que, conforme já comprovado, reforça o argumento da relação entre esse domínio e os condicionantes edáficos.

A principal questão que se coloca, atualmente, relaciona-se à atividade mineradora atuante dentro desse espaço natural protegido. Essas mineradoras promovem impacto negativo na paisagem da Serra de difícil recuperação. Cabe ressaltar que não se ponderou esse aspecto no ato de tombamento da Serra, pois permitiram que as mineradoras com histórico na área continuassem suas atividades.

A exploração mineral é de fundamental importância para a sociedade atual e deve ser objeto de planejamento sério e estratégico, para as atuais e para as novas áreas de exploração. No caso da Serra do Boturuna, algumas questões devem ser destacadas: será cabível que uma ANT inclua a exploração mineral como principal atividade econômica dentro dos seus limites? Esse fato não descaracteriza a finalidade do tombamento? Quais os procedimentos para a exploração mineral numa ANT? Os planos de recuperação de áreas degradadas, elaborados pelas mineradoras, seriam suficientes para sanar o ônus da exploração mineral e garantir os atributos de tombamento?

Essas questões fazem parte do contexto ambiental no qual se insere a Serra do Boturuna. Além do conflito inerente entre a preservação ambiental e a exploração dos recursos minerais, a Serra se insere em dois municípios com características econômicas distintas: Pirapora do Bom Jesus e Santana de Parnaíba. Logo, para cada município, a Serra do Boturuna possui uma 
importância distinta e, cada qual, dará uma valoração peculiar ao espaço físico da Serra.

Torna-se importante verificar até que ponto o instrumento jurídico do tombamento foi eficaz para a preservação das estruturas paisagísticas da Serra. Dessa forma, este trabalho analisa as características ambientais da Serra do Boturuna e o contexto que envolve o seu tombamento e os aspectos fundamentais que nortearam a exploração mineral na região.

A caracterização ambiental implica em importantes subsídios para a preservação da Serra do Boturuna. Essa caracterização deve considerar não somente o estágio atual da exploração de seus recursos minerais, assim, torna-se de fundamental importância descrever como ocorreu a apropriação histórica dos recursos naturais da região. Como há argumentos que justificam a preservação ambiental, há determinadas posturas e teses que justificam a mineração e afirmam que é possível reparar determinadas formas de degradação do meio físico. Por isso, é importante investigar como as mineradoras que atuam na região, trabalham com a questão da recuperação da área degradada. Será que os documentos legais de avaliação e recuperação ambiental como os Planos de Recuperação de Áreas Degradadas (PRADs) e os Estudos de Impactos Ambientais - Relatórios de Impactos Ambientais (EIA-RIMAs) são produzidos apenas por formalidade jurídica? Qual a aplicabilidade, no caso da Serra do Boturuna, desses instrumentos de recuperação ambiental? Essas questões justificam a análise da Serra do Boturuna, não somente na avaliação de seus recursos naturais, mas também no contexto econômico da exploração dos recursos minerais.

\section{OBJETIVOS}

Por se tratar de uma temática complexa que envolve tanto a preservação e a conservação ambiental, como a exploração dos recursos minerais dentro da ANT da Serra do Boturuna, considerou-se alguns objetivos.

Como objetivos gerais: caracterização do meio físico da Serra do Boturuna e a inserção desse maciço quartzítico no contexto paisagístico 
regional; análise da atividade minerária nos municípios de Pirapora do Bom Jesus e Santana de Parnaíba.

Como objetivos específicos: avaliação dos impactos causados pela exploração mineral na paisagem da Serra e as formas de mitigação e de recuperação propostas pelas mineradoras; análise da eficácia do tombamento natural da Serra e o grau de importância da atividade minerária para os municípios.

\section{LOCALIZAÇÃO E CARACTERÍSTICAS GERAIS DA ÁREA DE ESTUDO}

\subsection{SERRA DO BOTURUNA}

A Serra do Boturuna, ou Voturuna, é considerado um compartimento geomorfológico diferenciado no Planalto Atlântico, pois faz parte do grupo de serras que possuem como embasamento litológico o quartzito. Essa estrutura permite que esses maciços montanhosos se sobressaiam na paisagem regional em virtude da resistência de suas rochas aos processos erosivos.

A região do Boturuna já foi um dos principais pontos de extração de minérios do Estado de São Paulo. Há registros de exploração aurífera em 1590 realizadas por Affonso Sardinha, que descobriu "ouro de lavagem", ou ouro de aluvião nas proximidades do Morro do Boturuna e no Jaraguá (CAMARGO, 1971). Esse fato, possivelmente, juntamente com outros ensejos, estimulou os Bandeirantes Paulistas para desbravar o Interior à procura desse e de outros bens minerais. A exploração de ouro também contribuiu para 0 estabelecimento dos primeiros povoados da Província de São Paulo.

Verificaram-se também outros registros de exploração de ouro, datados do século XVIII, numa área que também se encontrava nas proximidades da Serra do Boturuna, no local conhecido como Rasgão, nas proximidades onde, atualmente, existe uma usina hidrelétrica com o mesmo nome.

Com relação ao contexto histórico dessas explorações, Saint-Hilaire (1976) chamou atenção para a exploração de ouro na região. A descrição feita por esse importante viajante e botânico sobre o Morro do Jaraguá, em seus 
relatos da viagem realizada em 1819, destaca a importância do ouro para a região:

O pico principal é tão pouco elevado que na região the é dado apenas o nome de morro (Morro de Jaraguá). No entanto, essas pequenas elevações têm, na história do Brasil, uma certa notoriedade, visto que contêm minas de ouro cuja exploração remonta a uma época muito antiga. Sua descoberta ocorre, segundo se diz, em 1590 e foi devida a um certo Afonso Sardinha, que nesse ano teria também verificado a existência de ferro na serra de Arraçoiba. Durante todo o século XVII foram retiradas consideráveis quantidade de ouro nas minas de Jaraguá, tendo elas sido apelidadas - segundo se afirma - de Peru do Brasil. (SAINTHILAIRE, 1976, p. 118).

Em 1820, José Bonifácio de Andrada e Silva e Martin Francisco Ribeiro de Andrada também destacavam a importância mineralógica da região, nos diários da viagem mineralógica na Província de São Paulo.

A vila da Parnaíba, situada quase no centro de um vasto distrito aurífero, entre as minas do Jaraguá, Japí, Penunduba, Montserrate, Alberta, Boturuna, Piedade, Pirapora e outras, é muito própria para se formar um centro metalúrgico e estabelecer uma Administração Geral. Afora o ouro, podiam-se extrair abundantes minerais de ferro hemático, vermelho e branco, excelente ferro magnético da rica mina de Pirapora e é provável que, entre os muitos veios quartzosos que cortam os seus contornos, se achem alguns que encerrem metais úteis. (sic) (SILVA; ANDRADA, 1954, p. 74).

É possível afirmar que a exploração mineral está presente na economia da região desde o estabelecimento dos primeiros colonizadores. Porém, num determinado contexto histórico, essa atividade trouxe significativas alterações na paisagem da Serra do Boturuna. Esse contexto relaciona-se com 0 crescimento urbano da Região Metropolitana de São Paulo (RMSP) e a necessidade de determinados recursos minerais. Isso fez com que o Boturuna, na década de 1980, fosse a principal área de extração de quartzito da RMSP. Nessa época, a Empresa Paulista de Planejamento Metropolitano (EMPLASA) definiu os municípios de Pirapora do Bom Jesus e Santana de Parnaíba como distritos mineradores.

Com relação à localização da ANT da Serra do Boturuna, destaca-se que o maciço quartzítico insere-se como limite físico entre os municípios de Santana de Paranaíba e de Pirapora do Bom Jesus no Estado de São Paulo (Mapa 1). Esses municípios integram e estão a noroeste da RMSP. O perímetro de tombamento inclui os dois municípios em questão, porém, a faixa de amortecimento de $300 \mathrm{~m}$ abrange também uma pequena porção no município de Araçariguama, a sudoeste da ANT. 


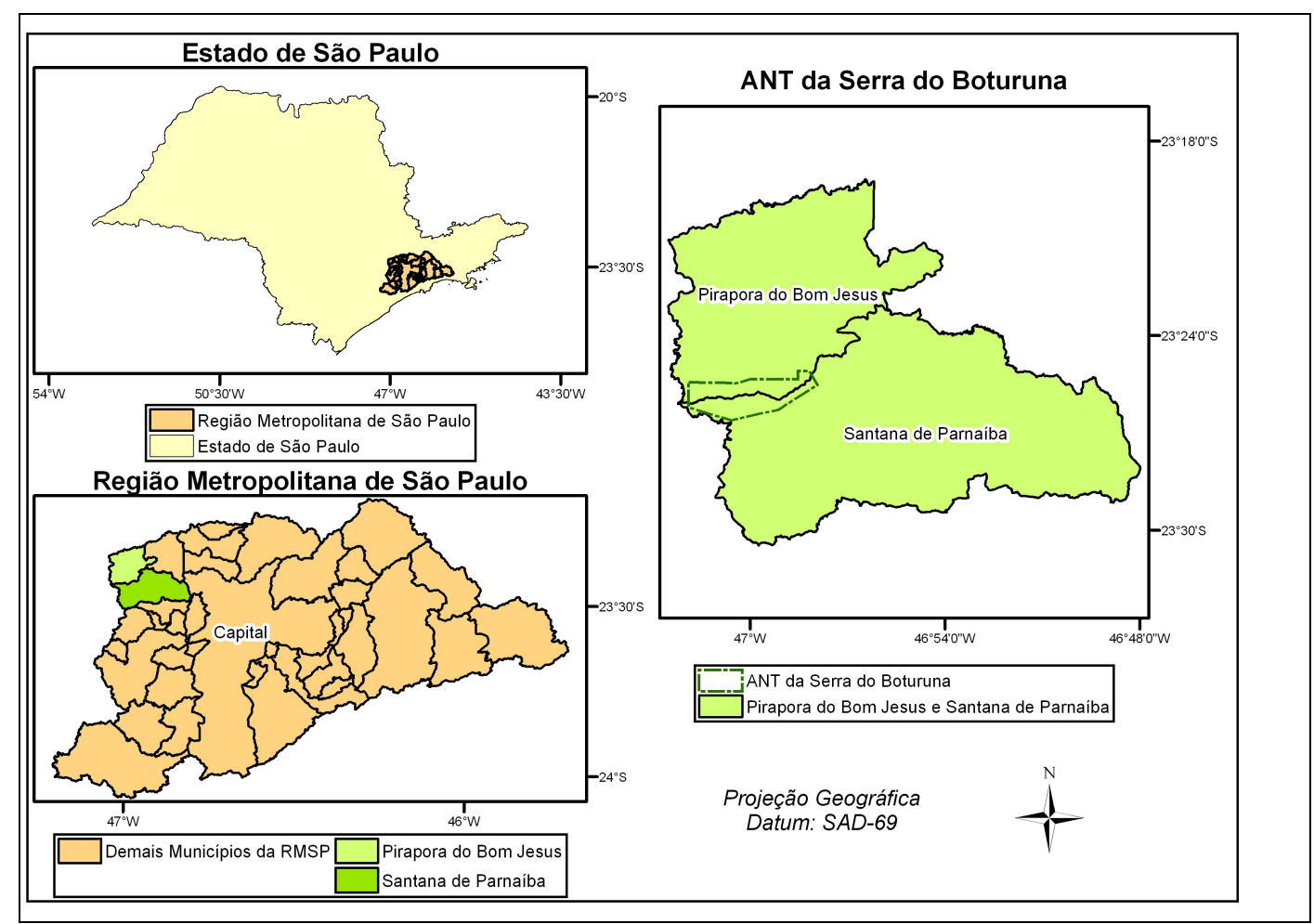

Mapa 1 - Localização da ANT da Serra do Boturuna, Estado de São Paulo

Boturuna é uma palavra do tronco indígena tupi que significa o monte negro (Ybytyr. o monte; o serro - una: preto; negro). A Empresa Paulista de Planejamento Metropolitano S.A. (EMPLASA) utiliza nas bases topográficas da região o topônimo Voturuna, mesma denominação utilizada por outras fontes consultadas para a pesquisa. Nota-se que a palavra indígena Ybytyruna e outras com o mesmo prefixo passaram por diversas alterações, entre as quais, a derivação da letra B para a V. Entretanto, aceitam-se as diversas grafias empregadas nessa palavra e em outras com o mesmo prefixo.

A montanha ou serro elevado diz-se, no tupí, ybyytra, que, como acima dissemos, se decompõe em yby-ityra, isto é, elevação de terra ou terra alta. A alteração metaplasmática desse vocabulo é a mesma dos seus componentes; por isso é frequente encontrarem-se denominações de logares com as graphias do radical: butur, ibitur, bitur, fórmas alteradas de ybytyra, as quaes se não devem confundir com as do vocabulo ybytú. No tupí do Sul, o vocabulo ybytyra, contrahido, de ybyty e, de suas diversas alterações, na composição de outros vocábulos, nasceram as fórmas: ibitú, bitu, botú. Os nomes Ibituruna, Boturuna ou Voturuna, são apenas fórmas diversas de um mesmo vocabulo - ybytyruna, que quer dizer monte. (SAMPAIO, 1928, p. 67 e 68). 
O ponto mais alto da Serra do Boturuna possui $1.206 \mathrm{~m}$ de altitude, porém, o Morro do Boturuna, que determinou a denominação da serra, possui $1.087 \mathrm{~m}$ de altitude.

A Serra do Boturuna é tombada pelo CONDEPHAAT, segundo a Resolução da SC n. 17, de 4 de março de 1983. O tombamento dessa área tem finalidade de proteger a serra quartzítica, os remanescentes da flora e da fauna regional e seus recursos hídricos. De acordo com a resolução de tombamento, os remanescentes florestais dão à Serra um caráter de refúgio forçado da natureza tropical na região.

Nesse sentido, o tombamento deve-se, sobretudo, ao valor ecológico e paisagístico da área, circunscrevendo, segundo o art. $3^{\circ}$. da resolução, "[...] ao acidente topográfico principal, sua cobertura vegetal e torrentes radiais, tendo em vista a necessidade de garantir a preservação de seus patrimônios ambientais, bióticos e paisagísticos."

A seguir descreveram-se as características dos municípios em que a ANT da Serra do Boturuna se insere, ou seja, Santana de Parnaíba e Pirapora do Bom Jesus.

\subsection{SANTANA DE PARNAÍBA}

A expedição realizada em 1561 pelos primeiros colonizadores encontrou um salto $12 \mathrm{~m}$ no rio Tietê, ou Anhembi (Anhemby) - denominação utilizada pelos indígenas - que fora descrito como a Cachoeira do Inferno. Nesse trecho não navegável do imponente paisagem do Tietê foi estabelecido o povoado de Parnaíba (CAMARGO, 1971).

A toponímia Parnaíba fornece importantes informações sobre o rio Tietê e as estruturas geomorfológicas percorridas por esse curso d'água no Planalto Atlântico Paulista. Após a passagem pela Bacia Sedimentar de São Paulo, o Tietê atravessa estruturas litológicas pré-cambrianas e percorre uma seqüência de morros e falhas geológicas que se inicia em Barueri. $O$ rio Tietê encaixa-se a essas estruturas e apresenta certa sinuosidade no seu curso. A adaptação estrutural faz com que a região também apresente diversos saltos e cachoeiras rumo ao Interior. Atualmente, alguns desses desníveis estão encobertos por 
águas, em virtude da construção de barragens para a geração de energia elétrica no seu leito.

Nas primeiras expedições rumo ao Interior o rio Tietê, as cachoeiras representavam um obstáculo para a navegação. De acordo com os relatos históricos, os índios denominavam os trechos encachoeirados do Tietê como Parnaíba, ou seja, lugar onde não se pode navegar. Porém, há diversos significados para esse termo indígena do tupi. Logo, dois significados merecem destaque: "lugar de muitas ilhas", que se refere às ilhas graníticas do Tietê; e "rio ruim ou impraticável", devido à dificuldade de navegar na região (CAMARGO, 1971). O primeiro trecho encachoeirado do Tietê estava, justamente, em Parnaíba.

Parnaíba surgiu da Fazenda Parnaíba de Manoel Fernandes Ramos que se adentrou pelo rio Anhembi e parou nesse primeiro obstáculo, onde estabeleceu roças de vários produtos agrícolas. Nesse sentido, Parnaíba, inicialmente, tornou-se uma região agrícola onde se fixaram populações da Capital (Vila de São Paulo). Um dos primeiros habitantes da região, talvez, tenha sido o Cacique Tibiriçá (CAMARGO, 1971).

No final do século XVI, Suzana Dias, neta de Tibiriçá, esposa de Manoel Fernandes Ramos e que, após sua morte, herdou a sesmaria de Parnaíba, transferiu sua residência para uma casa às margens do rio Tietê. Essa grande sesmaria, herdada por ela, estendia-se até Sorocaba e incluía uma área onde se estabeleceram importantes municípios do Estado como São Roque e Itu. Os filhos que Suzana Dias tivera com Manuel Fernandes Ramos desbravaram as matas da região e formaram as primeiras roças. Os 17 filhos de Suzana Dias formaram famílias e fixaram suas residências em Parnaíba (CAMARCO, 1971). Entretanto, André, Baltasar e Domingos tiveram papel fundamental na história da região e das monções para o Interior.

O povoado cresceu com a família de Suzana Dias. Posteriormente, ela se casou com Belchior Costa que, ao mudar-se para Parnaíba, trouxe seus filhos para a região (CAMARGO, 1971).

Parnaíba cresceu ao redor da Capela de Santana. Deve-se destacar que Suzana Dias e seu filho André Fernandes, além da construção de uma igreja, fizeram grandes doações de terra para a santa Santana, daí deriva o nome atual do município. 
André Fernandes, que substituiu seu pai na chefia do povoado parnaibano, fez diversas entradas para o sertão à procura, sobretudo, de metais preciosos. Essas entradas são acompanhadas do surgimento de novos povoados. Cabe ressaltar que, naquela época, a criação de povoados estava relacionada à fundação de uma capela. Domingos Fernandes estabeleceu uma capela em Itu, assim como Baltasar Fernandes construiu outra capela em Sorocaba (CAMARGO, 1971).

Parnaíba foi o centro irradiador para a formação de diversos povoados. De Parnaíba também partiram diversas bandeiras em direção ao Interior, isso fez com que a região fosse denominada o berço dos bandeirantes. Em Parnaíba, por exemplo, nasceu Bartolomeu Bueno da Silva, o Anhangüera.

No início do povoamento de Parnaíba, houve uma fase de grande progresso derivado, principalmente, da exploração mineral. Custódia Dias, filha de Suzana Dias, casou-se com Geraldo Betting, alemão e minerador profissional que estimulou a exploração mineral aurífera na região. Essa fase perdurou entre 1591 e 1602. A exploração mineral era feita em bateia nos cursos d'água, no Boturuna e num local denominado de Lavras (CAMARGO, 1971).

A exploração mineral atraiu moradores, trouxe certo desenvolvimento à Parnaíba e estimulou a organização de bandeiras para o sertão. O povoado passou a ser um dos principais pontos de partidas de bandeiras para o Interior, pois possuía uma localização estratégica, o que permitiu também o desenvolvimento comercial da Vila.

Em 14 de novembro de 1625, Parnaíba é elevada a Vila e André Fernandes torna-se seu primeiro Capitão-mor, sendo o maior título de uma Vila na época. Isso significava que ele era protetor da ordem e da justiça em sua comarca. Cabe ressaltar que Parnaíba foi uma das primeiras Vilas da Província de São Paulo.

Parnaíba era considerada uma das mais importantes Vilas da Província. Entretanto, a partir da segunda metade do século XVIII, devido à diminuição das bandeiras e à criação de novos povoados, a Vila começou a possuir certo declínio em sua importância. O dinamismo de Parnaíba passa a ser mais acentuado no século XVII com a abertura das vias de comunicação para Sorocaba, Itu e Jundiaí, sem passar pela Vila (MAGNANI, 1984). 
Em 1900, Parnaíba passa por uma nova fase de sua história, relacionada à construção de uma usina hidrelétrica na Cachoeira do Diabo, em empreendimento realizado pela empresa canadense Light. A construção da barragem e da usina movimentou a economia de Parnaíba e atraiu muitas pessoas para a região. A movimentação na Vila foi tão intensa que os agricultores da área rural do município abandonaram suas roças para participar dessa empreitada (CAMARGO, 1971).

Apesar do aumento das atividades comerciais durante os trabalhos de construção da barragem e da usina, ao término da obra tudo voltou à normalidade em Parnaíba. Na ocasião da concessão da obra, a administração pública considerou essa possibilidade, por isso, estabeleceram-se algumas cláusulas contratuais entre a Light e a Vila de Parnaíba para que a região adquirisse certo dinamismo econômico e comercial. Porém, não se cumpriu a maior parte desses dispositivos contratuais. Previa-se, por exemplo, a construção de uma linha de bonde entre Barueri e Pirapora do Bom Jesus, que na época fazia parte de Santana de Parnaíba (CAMARGO, 1971). A Vila tinha a esperança que essa construção traria desenvolvimento para a região, mas tal linha ficou apenas no projeto.

A usina hidrelétrica foi de fundamental importância para o desenvolvimento industrial da Capital, no início do século XX. No período entre 1901 e 1914, grande parte da energia elétrica consumida provinha dessa usina que, em 1949, passou a ser denominada como Edgard de Souza.

Em 1906, Parnaíba é elevada à categoria de cidade, na época já era utilizada a denominação Santana de Parnaíba, porém, oficialmente a cidade fora designada como Parnaíba e somente em 1944 foi oficializada a designação Santana de Parnaíba.

A melhoria das condições da Estrada dos Romeiros (SP-312) e a abertura das rodovias Castelo Branco e Anhangüera promoveram uma nova dinâmica ao município, pois diversas indústrias passaram a se instalar ao longo dessas rodovias. Isso provocou um aumento populacional do município, acompanhado de um processo de especulação imobiliária (MAGNANI, 1984).

Outro fato que contribuiu para 0 crescimento urbano e o desenvolvimento econômico desse município foi o empreendimento Alphaville, que abrange também parte do o município de Barueri. 
O empreendimento Alphaville foi planejado em meados da década de 1970. A idéia inicial consistia na a construção de um centro industrial para empresas não poluentes. Entretanto, incorporaram ao projeto a construção de um condomínio residencial, juntamente com o centro empresarial e comercial. Tal empreendimento, apesar das diversas críticas, trouxe um novo dinamismo ao município e um expressivo aumento populacional.

O aspecto histórico e a dinâmica atual fazem com que Santana de Parnaíba possua distintas fisionomias paisagísticas. Esse fato já era observado em meados da década de 1980:

[...] Parnaíba apresenta hoje, contornos diferenciados: traços de cidade industrial, dormitório e de veraneio coexistem com as características de pequena cidade do interior que mantém ainda um patrimônio cultural diferenciado, produto de quatro séculos de existência. (MAGNANI, 1984, p. 7).

Mesmo com 0 expressivo crescimento populacional, essas características continuam presentes no município.

Santana de Parnaíba, atualmente, possui pouco mais que 98 mil habitantes. Segundo a Fundação Estadual de Análise de Dados (SEADE), o município apresentou taxa de crescimento populacional médio anual de 5,82\% no período de 2000 a 2005. Os dados da Tabela 1 demonstram que o maior crescimento populacional do município aconteceu a partir da década de 1980. 
Tabela 1 - Evolução da população residente em Santana de Parnaíba - SP

\begin{tabular}{|c|c|}
\hline Ano & População \\
\hline 1820 & $2.300^{*}$ \\
\hline 1925 & 7.981 \\
\hline 1960 & 5.122 \\
\hline 1967 & 6.221 \\
\hline 1970 & 5.390 \\
\hline 1975 & 7.104 \\
\hline 1980 & 10.081 \\
\hline 1991 & 37.762 \\
\hline 2000 & 57.299 \\
\hline 2005 & 74.828 \\
\hline
\end{tabular}

Fonte: SILVA; ANDRADA (1954) - Dados de 1820; CAMARGO (1971) - Dados de 1925; MAGNANI (1984) - Dados de 1960, 1967 e 1975; Instituto Brasileiro de Geografia e Estatística (IBGE) - Censos Demográficos de 1970, 1980, 1991 e 2000; IBGE - Estimativa em 1996, segundo a Taxa Geométrica de Crescimento Anual (TGCA); SEADE - Estimativa em 2005, segundo a TGCA. *População da Vila de Parnaíba.

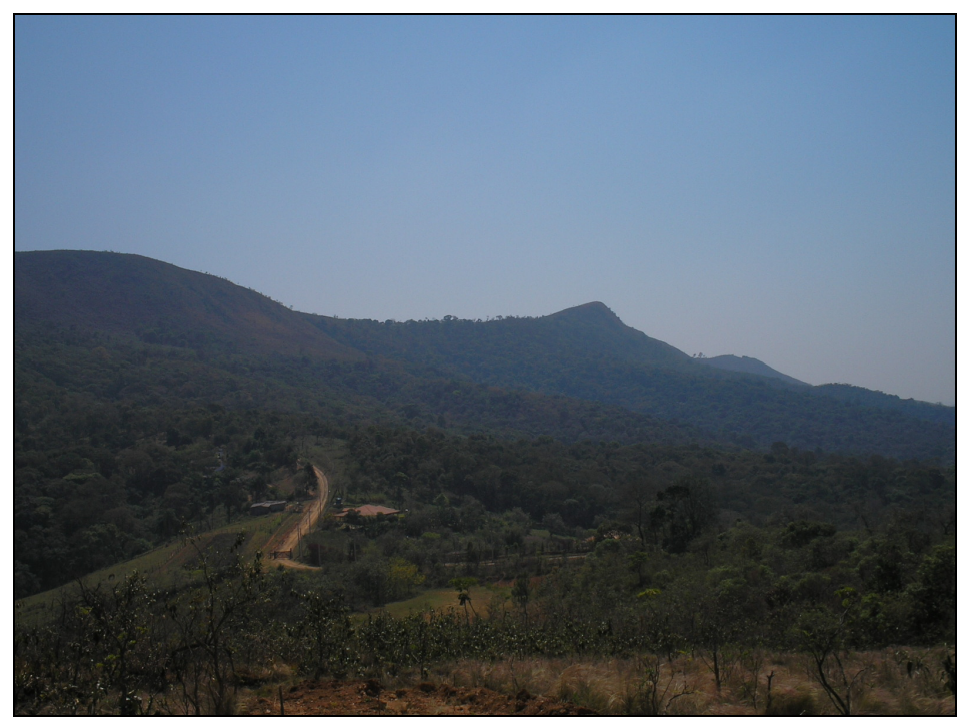

Figura 1 - Vertentes da Serra do Boturuna no município de Santana de Parnaíba - SP: Destaque para os remanescentes florestais (Sandro F. Detoni, setembro de 2006).

O município possui uma área de $180,04 \mathrm{~km}^{2}, 3,16 \%$, ou 569 ha dessa área correspondem a ANT da Serra do Boturuna ${ }^{4}$. A Serra do Boturuna possui ${ }^{4}$ Cálculos efetuados nas cartas na escala 1:10.000 do Sistema Cartográfico Metropolitano
(SCM). 
os maiores índices de remanescentes florestais em Santana de Parnaíba o uso do solo é composto, basicamente, por chácaras de lazer e por condomínios.

\subsection{PIRAPORA DO BOM JESUS}

Antigo bairro e distrito de Santana de Paranaíba, o município de Pirapora do Bom Jesus tem seu desenvolvimento atrelado à função religiosa. Pirapora surgiu de uma pequena fazenda, originada de uma sesmaria concedida em 1625, nas proximidades de um salto do rio Tietê. O termo indígena tupi Pirapora significa lugar onde peixe salta, relacionado aos saltos dos peixes ao passar pelo desnível do Tietê naquela região, o que também demonstra a influência desse importante curso d'água nos nomes de diversos municípios Paulistas.

A região de difícil acesso passa a se destacar somente em 1724 quando se encontrou a imagem do Bom Jesus de madeira tosca num pesqueiro à beira do rio Tietê (CAMARGO, 1971). O encontro "milagroso" da imagem resultou na atração de moradores para as proximidades e culminou com a construção da capela em 1725, assim, o pequeno povoado passa então a adquirir uma função religiosa regional.

Desde o início do povoado, o principal problema de Pirapora foi o isolamento relacionado à dificuldade de circulação e acesso. Num primeiro momento, a dificuldade era imposta pela navegação, pois o Tietê na região de Pirapora era composto por diversas corredeiras que se estendiam até a região de Itu. Esse fato também fez com que os Bandeirantes iniciassem as monções pelo rio Tietê na região de Porto Feliz.

A topografia montanhosa impôs certos limites à abertura de estradas que eram desviadas da região, o que contribuiu para o isolamento do povoado. No entanto, as últimas décadas do século XIX, o desenvolvimento da atividade religiosa trouxe certa integração na circulação regional à Pirapora. Em 1880, foi construída uma ponte de ferro sobre o rio Tietê, próximo ao núcleo urbano do povoado que fora muito importante para o desenvolvimento da cidade como centro de peregrinação religiosa, pois facilitaram os contatos com Cabreúva, Itu, Jundiaí, Piracicaba e Capivari (FRANÇA, 1964). 
A integração viária do povoado melhorou, em 1922, com a construção da Estrada Oficial São Paulo - Mato Grosso. O trecho São Paulo - Itu incluíra a ponte como passagem. Entretanto, a passagem por Pirapora diminui com a abertura, em 1952, da rodovia Marechal Rondon e o estabelecimento do trecho entre a via Anhangüera e Itu.

Uma boa estrada é capaz de fazer captações; foi o que aconteceu quando as principais comunicações por estrada de rodagem para Itu e daí para Oeste e Noroeste do Estado de São Paulo, desviaram-se, passando ao Norte da região de Pirapora. (FRANÇA, 1964, p. 34).

Em 1957, a estrada para Itu que passa por Pirapora foi pavimentada:

Aquela melhoria introduzida na velha via de acesso de São Paulo a Pirapora, compensaria, em grande parte a perda sofrida como centro intermediário de passagem, pois tornou muito mais cômoda a ligação com a Capital, reduzindo para metade do tempo da viagem por carro. Assim, Pirapora consolidaria sua posição satélite de grande centro urbano e poderia desenvolver maior atração, especialmente visitantes de fins de semana. (FRANÇA, 1964, p. 34 e 35).

O município já possuiu uma pequena expressão no setor agrícola. Porém, a degradação de seus solos e as dificuldades impostas pelo relevo não favoreceram esse setor e possibilitaram o povoamento de seu núcleo urbano pelo êxodo rural. Pirapora não possuía áreas favoráveis ao crescimento desse núcleo urbano, que se concentrou, até metade do século $\mathrm{XX}$, na pequena planície aluvial.

Desde o inicio do povoamento, um dos principais focos de atração populacional para Pirapora relacionava-se à atividade de mineração com destaque inicial para a exploração do ouro de aluvião.

O foco atrativo era a mineração, mas efetuada nas redondezas, para extrair os minerais contidos nas rochas cristalofilianas da Série denominada Açungui ou São Roque (Algonquiano). O ouro viria a ser prospectado na Serra do Boturuna, destacado maciço que se ergue ao Sul de Pirapora e na jazida do Cacupé, localizada junto ao Ribeirão Ponunduva. (FRANÇA, 1964, p. 42).

É possível destacar diversas fases de mineração em Pirapora, no entanto, apesar desse aspecto, sua principal função sempre estava relacionada à religião.

No século XIX, ocorreu a primeira fase de decadência econômica em Pirapora, relacionada ao desaparecimento da atividade mineradora e a decadência da agricultura comercial. Contudo, nesse período houve a melhora das condições da circulação regional ligada à importância da exaltação do Santo no momento de decadência. A melhora das vias de acesso não resultou 
no crescimento do município, em virtude da falta de bases econômicas para isso (FRANÇA, 1964).

Em 1892, é criado o distrito de Pirapora e, em 1896, instala-se na região o apostolado belga premonstratense. Esse fato resultou na construção de um seminário em 1905 e na organização dos cultos em novas bases (CAMARGO, 1971). O seminário tornou-se um elemento marcante na paisagem urbana de Pirapora do Bom Jesus e confirmou a função religiosa do local.

O culto ao Bom Jesus foi acompanhado do surgimento das romarias para Pirapora. A primeira romaria organizada foi a de Jundiaí em 1914, a partir dessa data, surgiram diversas outras. Já a primeira festa solene de culto ao Bom Jesus aconteceu em 6 de agosto de 1930 (FRANÇA, 1964).

Esses acontecimentos demonstram toda influência religiosa no povoamento de Pirapora do Bom Jesus. Deve-se destacar a importância do rio Tietê, tanto nas festividades como nas romarias suas águas, atualmente, com altas quantidades de poluentes, eram utilizadas para os rituais religiosos mais diversos. Os romeiros, por exemplo, ao chegarem à Pirapora, banhavam-se no Tietê. Durante a Festa do Bom Jesus, o Tietê era uma atração turística importante, devido aos seus barcos de passeios e às atividades de pesca.

A "[...] atividade religiosa, que se estende a outras das suas instalações e funções, suplanta tôdas as demais e as subordina" (FRANÇA, 1964, p. 50).

A emancipação de Pirapora do Bom Jesus de Santana de Parnaíba aconteceu em 1960. Desde então, a sua base econômica se concentrava no turismo religioso, característica marcante até os dias atuais. O município não possui produção agrícola significativa e a maioria da sua população está na área urbana. Destacam-se as atividades comerciais e as pequenas indústrias.

O município procura diversificar sua base econômica com a implantação de um parque industrial nas proximidades da ANT da Serra do Boturuna, numa área desapropriada pela Prefeitura e doada a um grupo de empresários, que receberam isenções fiscais e são responsáveis pela implantação da infraestrutura local.

O parque industrial será um elemento marcante da paisagem daquele local (Figura 2). Sem contar que é necessário um planejamento com relação à questão habitacional do município, pois um parque industrial, mormente, atrairá novos moradores ao município. Segundo informações da Prefeitura de Pirapora 
do Bom Jesus ${ }^{5}$, o parque será composto por cinco estabelecimentos industriais, sendo quatro indústrias do segmento de plásticos.

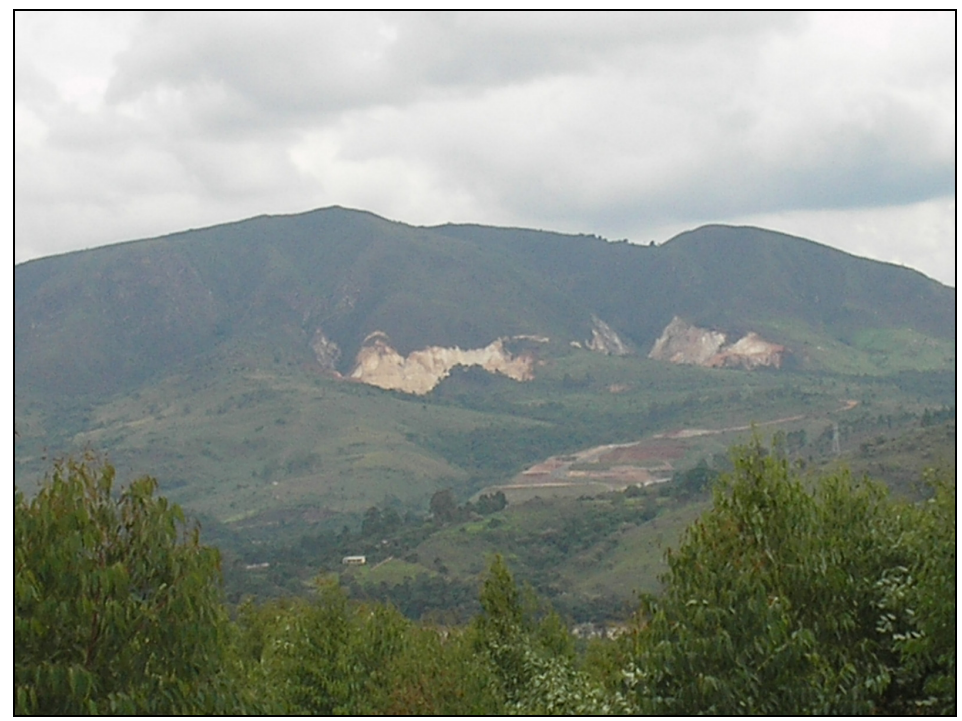

Figura 2 - Vertentes da Serra do Boturuna no município de Pirapora do Bom Jesus - SP: destaque para as áreas de mineração e a área do parque industrial em primeiro plano, à direita (Sandro F. Detoni, dezembro de 2006).

Nas vertentes da Serra do Boturuna voltadas para Pirapora, encontramse os maiores índices de degradação ambiental da ANT. Esse fato se relaciona, sobretudo, ao intenso desmatamento e a exploração minerária.

O rio Tietê já foi uma das principais atrações turísticas de Pirapora. De acordo com França (1964), na década de 1960, "É o turismo, que atrai habitantes da Capital paulista e de outros centros próximos, aos pique-niques e pesca de fim de semana, às margens do rio Tietê." (FRANÇA, 1964, p. 50).

Apesar dos projetos de saneamento e de tratamento de efluentes, 0 Tietê apresenta suas águas poluídas, o que ocasiona um sério problema ambiental para a região. A grande quantidade de matéria orgânica aliada ao pouco oxigênio, decorrente da eutrofização da água, favorece a proliferação de bactérias que produzem sulfetos. Estes gases provocam o mal-cheiro no ar o que resulta em inúmeras doenças respiratórias.

Ao passar pela barragem ${ }^{6}$ de Pirapora, a carga de esgoto doméstico transportado pelo rio Tietê ocasiona a formação de espumas sobre a lâmina d'água. Isso é resultado da presença de detergentes e outros produtos

\footnotetext{
${ }^{5}$ Informação pessoal cedida pelo coordenador de meio ambiente Ailton Paulo Pinto.

${ }^{6}$ A barragem de Pirapora e a Usina Hidrelétrica do Rasgão foram construídas em 1925.
} 
químicos dissolvidos em suas águas. O desnível da barragem faz com que a água se agite o que propicia a formação da espuma. Na época de estiagem, entre os meses de maio e agosto, a concentração dos poluentes é maior e, consequentemente, a quantidade de espuma também tende a aumentar.

As espumas no município de Pirapora do Bom Jesus já atingiram até cinco metros de altura. O Governo do Estado de São Paulo efetuou algumas medidas paliativas com o intuito de diminuir a quantidade de espuma nesse trecho rio Tietê. Porém, a solução depende da concretização dos projetos de saneamento básico relacionados à captação e ao tratamento dos efluentes domésticos na bacia do Alto Tietê.

Conforme demonstram a Tabela 2, até a década de 1960, o crescimento populacional da região apresentou-se, de certa forma, estagnado. No entanto, observa-se que após a emancipação, a partir da década de 1960, observa-se um maior aumento populacional no município. Concomitante, ocorreu um declínio de sua população rural. Em 1957, por exemplo, Pirapora do Bom Jesus apresentava 1.273 hab. na área rural e 871 hab. no perímetro urbano (CAMARGO, 1971).

Atualmente, o município apresenta somente alguns habitantes na área rural $^{7}$, possuindo população predominantemente urbana. As propriedades rurais do município, que não são destinadas ao lazer, possuem uma pequena produção agrícola. Destaca-se também que o município registra a produção de 50 toneladas de mel anuais. Apesar da pouca significância do setor rural, Pirapora do Bom Jesus assemelha-se a muitos pequenos municípios do interior Paulista pela sua tranqüilidade característica.

\footnotetext{
${ }^{7} \mathrm{Na}$ região há muitas chácaras, porém, somente algumas propriedades possuem produção agrícola para a comercialização.
} 
Tabela 2 - Evolução da população residente em Pirapora do Bom Jesus $\mathrm{SP}$

\begin{tabular}{|c|c|}
\hline Ano & População \\
\hline 1832 & 2.486 \\
\hline 1957 & 2.300 \\
\hline 1960 & 2.466 \\
\hline 1970 & 3.709 \\
\hline 1980 & 4.804 \\
\hline 1996 & 7.956 \\
\hline 2000 & 10.499 \\
\hline 2005 & 12.395 \\
\hline
\end{tabular}

Fonte: FRANÇA (1964) - Dados de 1832: Livros de População de Parnaíba Arquivo do Estado; CAMARGO (1971) - Dados de 1957; FRANÇA (1964) Dados de 1960: Estimativa do IBGE; IBGE - Censos Demográficos de 1970, 1980, 1991 e 2000; IBGE - Estimativa em 1996, segundo a TGCA; SEADE Estimativa em 2005, segundo a TGCA.

* Freguesia de Pirapora (Pertencia a Porto Feliz)

Pirapora do Bom Jesus possui uma população estimada de 15 mil habitantes. A ANT da Serra do Boturuna abrange 5,16\% da área total do município que é de 108,44 km², o que corresponde a 559 ha. De acordo com a SEADE, a taxa de crescimento populacional anual médio de Pirapora no período de 2000 a 2005 foi de $4,40 \%$.

\section{PAISAGEM E TEORIA GERAL DOS SISTEMAS}

O conceito de paisagem envolve distintas definições conforme o propósito analítico, por isso, esse conceito dota-se de certo subjetivismo e seu emprego pode variar conforme a ciência e o contexto. Na Geografia, por exemplo, a análise da paisagem e a utilização desse termo pressupõem uma abordagem metodológica e adquire uma conotação científica.

Alexander Von Humboldt foi um dos primeiros autores a definir e a fazer uso desse conceito segundo um princípio metodológico de análise. Esse geógrafo e naturalista alemão procurou decifrar a paisagem por meio das interrelações entre os componentes físicos básicos da natureza, porém, o foco de suas análises estava na interpretação das distintas fisionomias da vegetação 
que se constituiu na base para a elaboração de uma metodologia de análise da paisagem em Geografia.

O diferencial dessa abordagem geográfica da paisagem estava na análise integrada dos componentes da natureza, ou seja, o clima, o relevo, o solo, a litologia e a vegetação. Dessa forma, a paisagem resulta do equilíbrio dinâmico do sistema natural e sua característica dinâmica faz com que sua estrutura seja composta por heranças de processos passados, naturais ou antrópicos. Logo, essa categoria de análise também depende das condições atuais:

A paisagem não é a simples adição de elementos geográficos disparatados. É, numa determinada porção do espaço, o resultado da combinação dinâmica, portanto instável, de elementos físicos, biológicos e antrópicos que, reagindo dialeticamente uns sobre os outros, fazem da paisagem um conjunto único e indissociável, em perpetua evolução. A dialética tipo-indivíduo é o próprio fundamento do método de pesquisa. (BERTRAND, 1971, p. 2).

O pressuposto básico do conceito de paisagem encontra sua fundamentação teórica na Teoria Geral dos Sistemas, sendo uma das principais abordagens teórica utilizadas em Geografia Física.

A Teoria Geral dos Sistemas foi desenvolvida nos Estados Unidos por R. Defay (1929) e Ludwing von Bertalanffy (1932), tendo aplicação inicial nos estudos termodinâmicos e biológicos, por meio de uma perspectiva organística. De forma geral, essa teoria procura entender como as partes e o conjunto que forma a totalidade se relacionam, ou seja, procura entender a inter-relação e a interdependência entre os componentes que formam um sistema, considerado uma totalidade integrada.

Thornes e Brunsden (1977 apud CHRISTOFOLLETI, 1979, p.1) definem os sistemas como o "conjunto de objetos ou atributos e das suas relações, que se encontram organizados para executar uma função particular". Assim, o conjunto é composto por unidades organizadas que possuem inter-relações e geram uma determinada resposta do sistema:

[...] quando decidimos qual será o sistema a ser investigado, definindo os seus elementos e suas relações, torna-se mais fácil delimitá-lo no espaço e distinguir as suas unidades componentes, interligadas pelas relações internas, e estabelecer sistemas ambientais controlantes que atuam sobre os sistemas através das relações externas. (CRHISTOFOLLETI, 1979, p. 4).

A escolha do modelo teórico-metodológico foi condicionada ao objetivo da pesquisa, que foi analisar as variáveis ambientais e econômicas, ou 
antrópicas da região da Serra do Boturuna de forma integrada. Por isso, optouse pelo modelo relacional, pois há a valorização do conjunto com o intuito de decifrar a paisagem e seus condicionantes, sejam naturais ou antrópicos.

Ao aplicar os pressupostos da Teoria Geral dos Sistemas para o estudo do meio físico terrestre, deve ser considerados os fatores externos a determinado sistema, tais fatores são responsáveis pelo fornecimento de matéria e energia, o que estabelece os parâmetros que regulam seu funcionamento. Nesse contexto, trabalha-se com a idéia de transferência de massa e energia entre os subsistemas. No centro desse fluxo de massa e de energia está o conceito de entropia, descritos na segunda lei da termodinâmica, cujo funcionamento de qualquer sistema e de suas partes individuais pressupõe uma distribuição de energia desordenada e desigual, ou seja, vão da ordem para a desordem, logo, ocorre um aumento da entropia.

A entropia consiste em mensurar o grau de desordem de determinado sistema. A energia gerada nesse processo possibilita a realização de trabalho com o objetivo da busca do equilíbrio estacionário do sistema. Cabe ressaltar que isso ocorre somente em sistemas não isolados e em escala temporal restrita (CHRISTOFOLLETI, 1979).

Considera-se que os distintos ambientes da Terra se encontram em equilíbrio dinâmico. Todavia, a alteração no fluxo de massa e de energia pode alterar esse equilíbrio mediante qualquer intervenção nos elementos do sistema, o que faz com ocorra uma nova organização e a sua adaptação a uma nova situação. Isso significa que os diversos ambientes naturais terrestres possuem diferentes graus de suscetibilidade à quebra do equilíbrio.

O sistema, como um todo, possui uma estrutura constituída por seus elementos e as suas respectivas inter-relações. Essa estrutura será expressa pelo arranjo de seus componentes. Christofolleti (1979) definiu os seguintes componentes fundamentais da estrutura do sistema: elemento, tamanho, correlação e causalidade.

Conforme a escala de análise, o elemento é definido como a unidade básica do sistema. Já o tamanho do sistema é determinado pelo número de unidades que o compõem. A correlação é definida pelo modo de relação entre as variáveis. A causalidade está relacionada às variáveis do sistema, que pode 
ser uma variável independente, que controla o sistema, ou uma variável dependente, que é controlada pelo sistema.

$\mathrm{Na}$ análise geográfica, comumente, os sistemas são classificados por meio do critério funcional ou da complexidade estrutural. Este trabalho pressupõe a utilização do critério da complexidade estrutural. Por intermédio desse critério, Chorley e Kennedy (apud CHRISTOFOLLETI, 1979) distinguiram três formas de classificação dos sistemas: os sistemas morfológicos, os sistemas em seqüência e os sistemas de processosrespostas.

Os sistemas morfológicos baseiam-se na associação das propriedades físicas dos fenômenos. Considerados os menos complexos das estruturas naturais, tais sistemas possuem seu enfoque nas formas. Já os sistemas em seqüência são compostos por uma cadeia de subsistemas. Assim, deve-se analisar a entrada (input) e a saída (output) de energia e matéria do sistema. A análise da Serra do Boturuna considerará a combinação de sistemas morfológicos e de sistemas em seqüência, que é denominado sistemas de processos-respostas. A seqüência indica 0 processo e 0 morfológico representa a forma. Com isso, o conjunto da estrutura indica a relação entre os processos e as formas.

Conseqüentemente, pode-se estabelecer um equilíbrio entre o processo e a forma, de modo que qualquer alteração no sistema em seqüência será refletida por alteração na estrutura do sistema morfológico (isto é, na forma), através de reajustamento das variáveis, em vista a alcançar um novo equilíbrio, estabelecendo uma nova forma. Por outro lado, as alterações ocorridas nas formas podem alterar a maneira pela qual o processo se realiza, produzindo modificações na qualidade dos inputs fornecidos ao sistema morfológico. (CHRISTOFOLLETI, 1979, p. 17).

Nesse contexto, a busca do equilíbrio faz com que o sistema possua uma circularidade da ação, denominado mecanismo de retroalimentação (feedback). "O equilíbrio de um sistema representa o ajustamento completo das suas variáveis internas às condições externas [...]" (CHRISTOFOLLETI, 1979, p. 57). A condição de equilíbrio de determinada paisagem depende dessa combinação de variáveis internas, o que resultará em uma determinada fisiologia da paisagem. O estado de estabilidade é atingido quando a importação e a exportação de matéria e energia forem equacionadas por meio 
do ajustamento das formas do próprio sistema. Essa estabilidade permanece constante ao passo que não se alterarem as condições externas.

Em síntese, as trocas de energia se processam por meio das relações de equilíbrio dinâmico. Em virtude disso, uma determinada intervenção no espaço pode alterar a funcionalidade dos ambientes naturais e modificar a velocidade dos processos como ocorre em alguns setores da Serra do Boturuna.

Os ambientes naturais possuem distintos índices de suscetibilidade às intervenções humanas. O relevo constitui um bom indicador do desequilíbrio do sistema terrestre, pois a alteração no fluxo de matéria e de energia dentro do sistema é facilmente percebida na topografia por meio da alteração na estrutura superficial da paisagem. No entanto, a compreensão da estrutura paisagística deve se basear na análise integrada do espaço. "Os estudos integrados de um determinado território pressupõe o entendimento da dinâmica de funcionamento natural com ou sem a intervenção das ações humanas." (ROSS, 1994, p. 64).

Num primeiro momento, a análise da paisagem deve compreender a dinâmica natural da área sem a intervenção humana. Nessa fase, a ênfase está nos componentes físicos e bióticos que contribuem para a funcionalidade do sistema e envolve a integração dos estudos da litologia, do solo, do relevo, da vegetação e do clima. Posteriormente, consideram-se as intervenções por meio da análise do uso e ocupação do solo da área (ROSS, 1994). A análise das variáveis ambientais e antrópicas permitirão a caracterização integrada dos componentes paisagísticos da Serra do Boturuna.

Com relação ao uso e ocupação do solo, a componente histórico permitirá avaliar quais os fatores predominantes na alteração da paisagem regional. As atividades econômicas deixam suas marcas na paisagem. Logo, as características paisagísticas atuais decorrem, muitas vezes, dos modelos econômicos pretéritos. A exploração minerária, as técnicas, os produtos agrícolas cultivados e as forma de se apropriar do território determinaram a evolução da paisagem para os moldes atuais. Por meio da análise histórica, é possível traçar um prognóstico sobre as intervenções espaciais e verificar as tendências de apropriação dos recursos naturais. 
A estrutura paisagística natural possui uma determina função para a sociedade, a qual atribuiu e atribui uma determinada valoração aos recursos naturais disponíveis. Exploram-se os recursos em função do custo de apropriação e da demanda de consumo. Com a diminuição da biodiversidade do planeta, um novo componente passou a ser considerado na exploração indiscriminada dos recursos naturais: a manutenção dos ecossistemas. Convém destacar que, atualmente, o componente natural também possui sua valoração.

No estudo da ANT da Serra do Boturuna, consideraram-se, num primeiro momento, os aspectos naturais e suas dinâmicas no conjunto da paisagem. As formas de apropriação dos recursos naturais da Serra definiram distintas unidades paisagísticas relacionadas ao grau de preservação e degradação ambiental. Assim, o impacto negativo na paisagem condiciona-se, sobretudo, à estrutura econômica e social da região.

A preservação e a conservação ambiental possuem um conjunto de leis específicas e componentes jurídicos que não se relacionam à questão, mas que possuem, muitas vezes, influência direta nessa temática. A aplicação da lei e o estabelecimento de índices de qualidade ambiental eficientes dependem de um sistema organizado de fiscalização. A exploração dos recursos minerais, por exemplo, condiciona-se por distintos instrumentos jurídicos. Além da legislação especifica no âmbito minerário, a atividade deve seguir um conjunto de normas dispostas pela legislação ambiental. A própria resolução de tombamento da Serra do Boturuna, de certa forma, impõe restrições para a atividade no perímetro de proteção. Todavia, como o aparato jurídico envolve interpretação e hierarquização das leis, nem sempre é possível aplicar as disposições legais. As contradições regulatórias também conduzem o conflito entre a exploração dos recursos minerais e a preservação da paisagem da Serra.

A legislação constitui-se num importante mecanismo para o estabelecimento de medidas de preservação ambiental na ANT. Nesse contexto, não é possível realizar a análise ambiental de uma ANT sem o aparato legal que envolve sua proteção, Por isso, essa temática também se constitui numa das análises da pesquisa. 


\section{ESPAÇOS TERRITORIAIS ESPECIALMENTE PROTEGIDOS}

\subsection{CONTEXTO MUNICIPAL}

A questão da preservação e conservação de remanescentes florestais na RMSP é de fundamental importância para a melhoria da qualidade ambiental das suas áreas urbanas. A Serra do Boturuna insere-se numa das regiões mais densamente povoadas da América Latina. A ocupação e a expansão urbana da metrópole Paulista, muitas vezes, orientaram-se sem qualquer planejamento territorial e ambiental. Ao considerar esses aspectos, as áreas onde se destacam as matrizes paisagísticas naturais necessitam de políticas públicas orientadas para a sua preservação.

Antes da análise específica da ANT da Serra do Boturuna, torna-se necessário contextualizá-la no âmbito dos espaços territoriais especialmente protegidos ${ }^{8}$ por lei nos municípios onde a área tombada se insere. Por isso, efetuou-se o levantamento das demais unidades de conservação, ou espaços territoriais especialmente protegidos, presentes em Pirapora do Bom Jesus e em Santana de Paranaíba.

Os municípios envolvidos na pesquisa possuem em seus limites três espaços territoriais especialmente protegidos ${ }^{9}$ : a Área de Proteção Ambiental (APA) da Várzea do Tietê ${ }^{10}$, a Área Natural Tombada da Serra do Boturuna e a Área Natural Tombada da Serra do Japi, ou Serras do Japi, Guaxinduba e Jaguacoara (Tabela 3 e Mapa 2).

Tabela 3 - Áreas dos municípios e dos espaços territoriais especialmente protegidos

\begin{tabular}{|c|c|}
\hline Município e Espaço Territorial Especialmente Protegido & Área (km $\left.\mathbf{~}^{\mathbf{}}\right)$ \\
\hline Santana de Parnaíba & 180,04 \\
\hline Pirapora do Bom Jesus & 108,44 \\
\hline ANT da Serra do Boturuna & 11,29 \\
\hline ANT da Serra do Japi, ou Serras do Japi, Guaxinduba e Jaguacoara & 191,65 \\
\hline APA Várzea do Tietê & 74,00 \\
\hline
\end{tabular}

\footnotetext{
${ }^{8}$ Utiliza-se essa denominação, pois a categoria ANT não faz parte do Sistema Nacional de Unidades de Conservação.

${ }^{9}$ A referência para o cálculo das áreas foram as coordenadas geográficas dos espaços territoriais especialmente protegidos.

${ }^{10}$ Lei Estadual n. 5.598, de 06 de fevereiro de 1987 (Regulamentada pelo Decreto Estadual n. 42.837 de 03 de fevereiro de 1998).
} 
Mapa 2 - Espaços Territoriais Especialmente Protegidos: Pirapora do Bom Jesus e Santana de Parnaíba, Estado de São Paulo

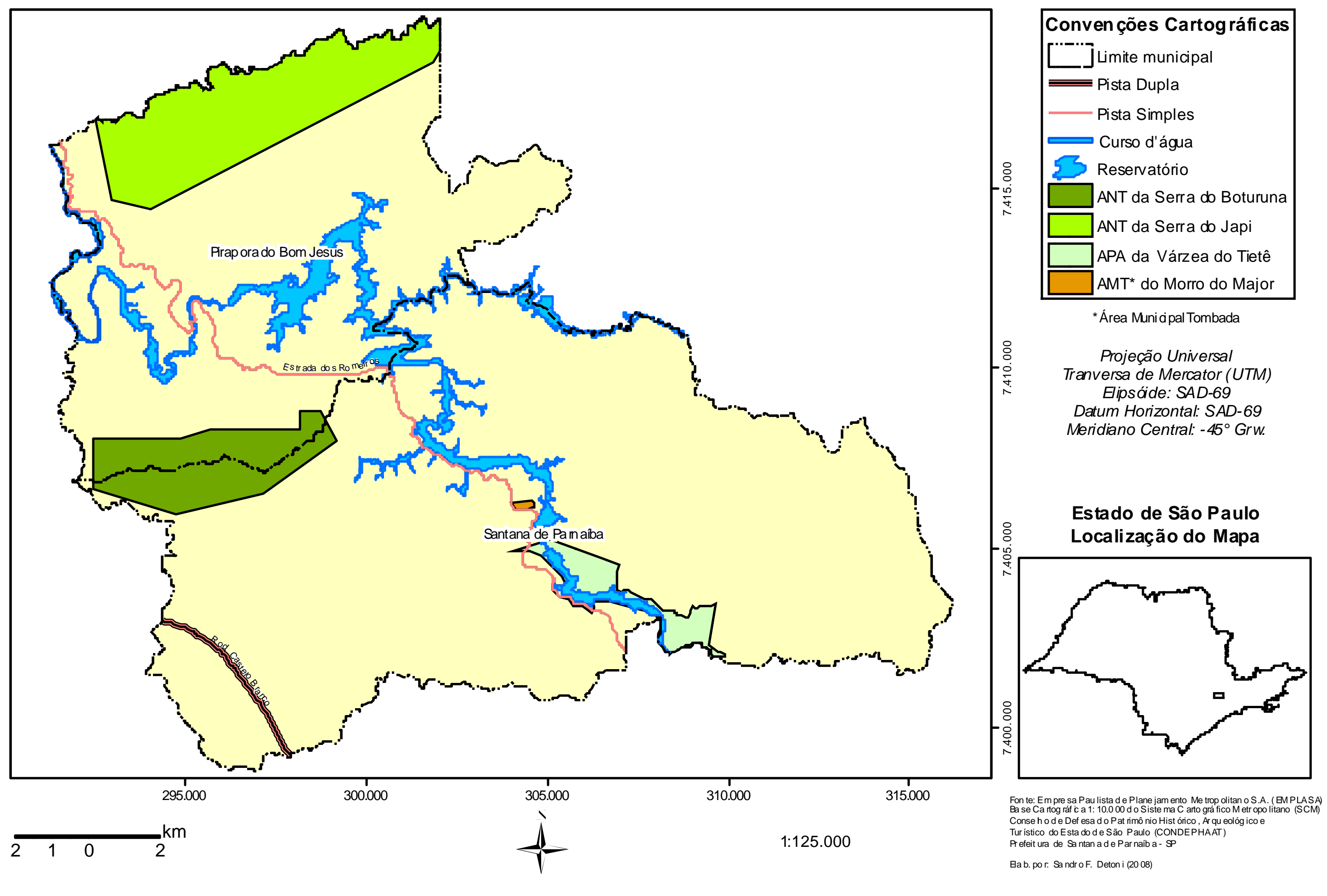


Convém destacar que parte do setor oeste da APA da Várzea do Tietê localiza-se no município Santana de Paranaíba, nas margens do Reservatório Edgard de Souza, porém, o setor oeste da APA também inclui os municípios de Osasco, Barueri e Carapicuíba. A área total dessa APA é de $74 \mathrm{~km}^{2}$, cuja área de $4,58 \mathrm{~km}^{2}$ localiza-se em Santana de Parnaíba e corresponde a 3,54\% da área do município ${ }^{11}$. Ao excluir área aproximada da bacia de acumulação de água do Reservatório Edgar de Souza, a área da APA apresenta em torno de $3,52 \mathrm{~km}^{2}$, ou seja, aproximadamente, $1,96 \%$ da área do município ${ }^{12}$.

A ANT da Serra do Boturuna, em Santana de Parnaíba, abrange 5,69 $\mathrm{km}^{2}$, ou seja, esse valor corresponde a $3,16 \%$ da área do município, conforme a Tabela 4. Nesse sentido, os espaços territoriais especialmente protegidos Estaduais ocupam 5,71\% da área do município (Tabela 5).

Santana de Parnaíba também possui uma área natural tombada municipal, denominada Morro do Major, ou do Cruzeiro, que foi criada pela Lei Municipal n. 1.840/94. O Morro do Major constitui-se num pequeno remanescente florestal próximo ao centro histórico de Santana de Parnaíba com aproximadamente 11 ha, em parte composto por construções e arruamentos. A área é considerada o mirante de Santana de Parnaíba e na década de 1920, fornecia água para o abastecimento da população, em virtude da construção de uma caixa d'água no sopé do morro para o aproveitamento da água da denominada biquinha.

Em Pirapora do Bom Jesus, a ANT da Serra do Boturuna envolve 5,59 $\mathrm{km}^{2}$, sendo $5,16 \%$ do seu território (Tabela 4). O município também possui parte da ANT da Serra do Japi, que se constitui como um dos principais remanescentes florestais de Pirapora do Bom Jesus.

A ANT da Serra do Japi foi criada pela Resolução Estadual n. 11 de 08/03/1983. Com uma área total de $191,65 \mathrm{~km}^{2}$, seu perímetro abrange se estende pelos municípios de Jundiaí, de Cabreúva, de Cajamar e de Pirapora do Bom Jesus. Considerado um importante remanescente florestal do Planalto Atlântico Paulista, a ANT da Serra do Japi serviu como referência para que as

\footnotetext{
${ }^{11}$ Cálculos efetuados sobre a base cartográfica digital dos limites da APA, obtida junto à Prefeitura de Santana de Parnaíba - SP.

12 Deve-se ressaltar que os cálculos se basearam na delimitação do reservatório obtida nas cartas 1: 10.000 do SCM, sem considerar a bacia de acumulação na vazão máxima.
} 
regiões rurais e urbanas dos municípios de Jundiaí ${ }^{13}$, de Cabreúva $^{14}$ e de Cajamar $^{15}$ fossem declaradas APAs. Somente as APAs de Jundiaí e de Cabreúva são regulamentadas, logo, estabeleceram-se para essas áreas as normas e as diretrizes de uso e ocupação do solo que envolve o zoneamento ambiental e a constituição de um colegiado gestor.

Em Pirapora do Bom Jesus, a ANT da Serra do Japi abrange $20,55 \mathrm{~km}^{2}$, o que corresponde a $18,95 \%$ do espaço territorial do município. A Tabela 5 demonstra que o município possui $24,11 \%$ do seu território compreendidos por Áreas Naturais Tombadas.

Deve-se destacar que o cálculo da ANT não considerou o perímetro de $300 \mathrm{~m}$, referente à zona de amortecimento, o que incluiria um pequeno setor no município de Araçariguama.

O Plano Diretor do município de Pirapora do Bom Jesus, que foi elaborado em 2004 em parceria com a EMPLASA, propõe, como principal diretriz na área ambiental, a criação da APA Pirapora Sul, na Serra do Boturuna, e da Pirapora Norte, na Serra do Japi, juntamente com o estabelecimento do Zoneamento Ecológico-Econômico (ZEE), conforme a Resolução n. 10/88 do Conselho Nacional de Meio Ambiente (CONAMA). Contudo, a Prefeitura de Pirapora do Bom Jesus, por intermédio do coordenador de meio ambiente Ailton Paulo Pinto, declarou que não há cronograma, nem perspectiva para a implantação dessas APAs.

Tabela 4 - Distribuição dos espaços territoriais especialmente protegidos em Pirapora do Bom Jesus - SP e em Santana de Parnaíba - SP

\begin{tabular}{|c|c|c|c|}
\hline $\begin{array}{c}\text { Espaço Territorial Especialmente } \\
\text { Protegido }\end{array}$ & $\begin{array}{c}\text { Área } \\
\mathbf{( k m}^{2} \mathbf{)}\end{array}$ & $\begin{array}{c}\text { Porcentagem no Espaço } \\
\text { Territorial Especialmente } \\
\text { Protegido }\end{array}$ & $\begin{array}{c}\text { Porcentagem } \\
\text { da Área no } \\
\text { Município }\end{array}$ \\
\hline $\begin{array}{c}\text { ANT da Serra do Boturuna em } \\
\text { Santana de Parnaíba }\end{array}$ & 5,69 & $50,44 \%$ & $3,16 \%$ \\
\hline $\begin{array}{c}\text { ANT da Serra do Boturuna em } \\
\text { Pirapora do Bom Jesus }\end{array}$ & 5,59 & $49,56 \%$ & $5,16 \%$ \\
\hline $\begin{array}{c}\text { ANT da Serra do Japi em Pirapora } \\
\text { do Bom Jesus }\end{array}$ & 20,55 & $10,72 \%$ & $18,95 \%$ \\
\hline $\begin{array}{c}\text { APA Várzea do Tietê em Santana } \\
\text { de Parnaíba }\end{array}$ & 4,58 & 6,19 & $2,54 \%$ \\
\hline
\end{tabular}

\footnotetext{
${ }^{13}$ Lei Estadual n. 4.095 de 12 de junho de 1984 (Regulamentado pelo Decreto Estadual n. 43.284 de 03 de julho de 1998)

${ }^{14}$ Lei Estadual n. 4.023 de 22 de maio de 1984 (Regulamentado pelo Decreto Estadual n. 43.284 de 03 de julho de 1998)

${ }^{15}$ Lei Estadual n. 4.055 de 04 de junho de 1984
} 
Tabela 5 - Abrangência dos espaços territoriais especialmente protegidos em Pirapora do Bom Jesus - SP e em Santana de Parnaíba - SP

\begin{tabular}{|c|c|c|}
\hline Municípios & Área $\left.\mathbf{( k m}^{\mathbf{2}}\right)$ & $\begin{array}{c}\text { Porcentagem da Área no } \\
\text { Município }\end{array}$ \\
\hline Santana de Parnaíba & 10,27 & $5,71 \%$ \\
\hline Pirapora do Bom Jesus & 26,14 & $24,11 \%$ \\
\hline
\end{tabular}

Apesar de Santana de Parnaíba possuir maior extensão territorial, ao comparar os dois municípios, verifica-se que Pirapora do Bom Jesus possui uma maior área de espaços territoriais especialmente protegidos. Isso significa que, se a legislação fosse aplicada por completo, haveria restrições no uso e ocupação do solo em, aproximadamente, $25 \%$ do território desse município.

\section{2 ÁREA NATURAL TOMBADA}

A etimologia do termo tombamento remonta ao sistema jurídico português que atribui o verbo tombar ao ato de tombar, registrar, ou inventariar bens. Em Portugal, os bens de importância histórica, cultural e paisagística eram registrados no livro localizado na Torre do Tombo (MACHADO, 2004). Por isso, convencionou-se inscrever o bem tombado no Livro Tombo existente na repartição pública que efetua 0 processo de tombamento, no caso do Estado de São Paulo, o Conselho de Defesa do Patrimônio Histórico, Arqueológico, Artístico e Turístico do Estado de São Paulo (CONDEPHAAT).

O art. 261 da Constituição do Estado de São Paulo dispõe que:

O Poder Público pesquisará, identificará, protegerá e valorizará o patrimônio cultural paulista, através do Conselho de Defesa do Patrimônio Histórico, Arqueológico, Artístico e Turístico do Estado de São Paulo - CONDEPHAAT, na forma que a lei estabelecer. (Art. 261 da Constituição do Estado de São Paulo).

A legislação de tombamento é autônoma e concorrente, ou seja, cada nível de gestão possui a sua legislação especifica. No Estado de São Paulo, a Lei Estadual n. 10.247/68 atribui ao CONDEPHAAT, órgão vinculado à SC, a competência para propor às autoridades competentes o tombamento, ou seja, o CONDEPHAAT não realiza o ato de tombamento, mas elabora o processo e pode opinar previamente sobre a matéria.

De acordo com o art. 14 do Decreto Estadual n. 13.426/79, o Conselho mantém cinco Livros de Tombo. $\mathrm{O}$ tombamento de áreas naturais é registrado 
no Livro I, denominado Livro do Tombo Arqueológico, Etnográfico e Paisagístico.

A criação de uma área natural tombada deve-se, prioritariamente, ao seu valor paisagístico. De acordo com Ab'Sáber (2004), pode-se estabelecer alguns critérios para o tombamento natural de uma área, entre os quais: as áreas de criticidade múltipla, em que haja interesse de uma proteção integrada dos tecidos ecológicos regionais; a distinção entre paisagens reconhecidamente banais e paisagens reconhecidamente de exceção, por exemplo, os morros testemunhos, as topografias ruiniformes, as pedras-tortas, os campos de matacões, os canyons, as feições cársticas, etc; os remanescentes primários de áreas topograficamente banais, porém, ecologicamente e bioticamente críticas com relação ao banco de germoplasmas e amostras intocáveis de ecossistemas primários em vias de extinção; e as áreas de introdução ou reintrodução de espécies, por exemplo, os velhos hortos.

O tombamento da área significa que a mesma está sujeita a um determinado ordenamento territorial. Do ponto de vista jurídico, no caso do tombamento da Serra do Boturuna, implica na proteção natural da Serra, pois restringe seu uso para a manutenção, sobretudo, de suas características paisagísticas, turísticas e científicas, ou seja, consiste na limitação do direito de propriedade. Assim, o tombamento é um instrumento ordenador do Estado que possui o objetivo principal de restringir o exercício sobre bens de seu domínio e sobre os direitos de utilização por parte do proprietário. A área tombada não necessita ser desapropriada, ou seja, não impede o uso do bem, mas restringe determinadas alterações que passam a depender de autorização do órgão competente no caso, o CONDEPHAAT. O tombamento também garante os direitos adquiridos sobre instalações e usos já implantados, todavia, os mesmos devem estar regularmente aprovados.

A relevância cultural ou natural do bem tombado faz com que o órgão responsável pelo seu tombamento garanta a sua preservação. $O$ ato de tombar um bem é precedido pelo processo de tombamento com a definição do tombamento provisório do bem. Entretanto, o tombamento provisório se equipara ao definitivo, sendo descrito no art. 146 do Decreto Estadual n. 13.426/79. Dessa forma, a abertura de um processo de tombamento 
automaticamente implica na preservação do bem. Isso faz com que o tombamento seja uma das formas mais rápidas para garantir a preservação.

As Áreas Naturais Tombadas, se considerado os critérios técnicos, não se constituem em unidades de conservação. A Lei Federal n. 9.985/2000, que instituiu o Sistema Nacional de Unidades de Conservação (SNUC), dividiu as categorias de unidades de conservação em dois grupos específicos: as unidades de proteção integral e as unidades de uso sustentável. Porém, em nenhuma das categorias está incluída as ANTs.

Convém destacar que, a Lei Estadual n. 9.509/97, que dispõe sobre a Política Estadual de Meio Ambiente, definiu no art. $3^{\circ}$., inciso VII, as seguintes unidades de conservação: Parques, Florestas, Reservas Biológicas, Estações Ecológicas, Áreas de Relevante Interesse Ecológico, Monumentos Naturais, Jardins Botânicos, Jardins Zoológicos e Hortos Florestais, e outras definidas em legislação específica. Entretanto, não há legislação específica que defina as Áreas Naturais Tombadas como unidades de conservação.

O tombamento é realizado via resolução do secretário da cultura no momento da manifestação favorável do colegiado. Nesse sentido, o secretário da cultura também possui poderes para rejeitar o pedido de tombamento.

O reconhecimento da excepcionalidade e da aplicabilidade do estatuto do tombamento - em cotejo com outros instrumentos de preservação - dependerá sempre do consenso obtido pelo aconselhamento responsável das comunidades científicas, técnicas e culturais. Nada feito, se a linguagem dos técnicos e dos cientistas não tiver suficiente força e abrangência para sensibilizar intelectuais, ambientalistas, governos e público em geral. (AB'SÁBER, 2004, p. 379).

Os proprietários que apresentarem uma impugnação ao processo de tombamento podem, caso aprovado o ato de tombamento, solicitar um recurso ao governador para contestar a medida. Verifica-se que tal possibilidade não é possível no ato de criação de uma unidade de conservação, em virtude de sua configuração como ato legislativo. No entanto, como o tombamento envolve a publicação de uma resolução da Secretaria da Cultura, somente outra resolução, elaborada pelo colegiado, pode cancelar esse instrumento de preservação.

A principal característica jurídica do tombamento consiste na restrição dos direitos de utilização da propriedade privada. "Entretanto, sobre o bem 
privado passa a haver um regime jurídico de tutela pública." (MACHADO, 2004, p. 894).

O ato de tombamento de uma área ou de uma edificação atinge as propriedades públicas, privadas, físicas ou jurídicas. Assim, o Poder público deve gerir o bem tombado. No caso de propriedade pública o bem se torna inalienável. Esses aspectos definem o bem privado como de interesse público.

Diversas teorias jurídicas têm sido expostas para caracterizar tal regime jurídico: limitação administrativa da propriedade privada, servidão administrativa, propriedade coletiva dominial, domínio eminente estatal, bem cultural como bem imaterial, propriedade privada com função social, bem de interesse público. (MACHADO, 2004, p. 894).

A proteção e a manutenção do bem tombado tornam-se, assim, responsabilidade do CONDEPHAAT. Nesse sentido, esse órgão deve garantir recursos para a sua manutenção e prever os danos que, no caso de áreas naturais tombadas, estão relacionados à degradação ambiental.

Não só o proprietário da coisa tombada é responsável pela sua conservação e reparação, Invocável a co-responsabilidade do Poder público que tenha tombado a coisa, desde que se comprovem dois requisitos: que não tenha sido o proprietário o causador do dano e que a reparação seja necessária. (MACHADO, 2004, p. 898).

A institucionalização de uma área natural deve-se as suas características naturais ou produzidas pela ação humana. Assim, "O apelo ao recurso do tombamento somente é aplicável a uma área ou gleba que, por razões paisagísticas, ecológicas, hídricas ou ambientais, seja reconhecidamente uma área necessitada de proteção integral." (AB'SÁBER, 2004, p. 379).

Semelhante ao que ocorre com as unidades de conservação descritas no SNUC, a legislação de tombamento também fixa uma área de entorno com o objetivo de garantir a visibilidade do objeto tombado, ou seja, um tampão de defesa ecológica (zona de amortecimento), ou Ecological buffer zone. O art. 137 do Decreto Estadual $n^{\circ}$. 13.426/79 dispõe que:

Nenhuma obra poderá ser executada na área compreendida num raio de 300 (trezentos) metros em torno de qualquer edificação ou sítio tombado, sem que o respectivo projeto seja previamente aprovado pelo Conselho, para evitar prejuízo à visibilidade ou destaque do referido sítio ou edificação. (DECRETO ESTADUAL N. 13.426/79).

Alterou-se a redação desse artigo por meio do Decreto Estadual $\mathrm{n}$. 48.437/2003, no qual impôs maior flexibilidade às restrições de entorno. Assim, prevê-se o estabelecimento de uma área de entorno quando a ocupação e o 
uso revelarem-se aptos a prejudicar a qualidade ambiental do bem sob preservação. Com isso, a dimensão da área envoltório deve ser definida caso a caso. Apesar dessa alteração, na ANT da Serra do Boturuna incide-se a jurisprudência anterior.

Apesar de um importante instrumento de preservação ambiental, verifica-se que a legislação de tombamento abrange mais os aspectos relacionados ao bem imóvel e às edificações do que, propriamente, a uma ANT. Assim, em determinados casos, os dispositivos estabelecidos na forma da lei possuem pouca aplicabilidade num espaço natural protegido.

\subsection{TOMBAMENTO DA SERRA DO BOTURUNA}

A iniciativa do tombamento natural da Serra do Boturuna partiu dos moradores do Condomínio Voturuna, localizado em Santana de Parnaíba. Em 1982, foi encaminhado ao CONDEPHAAT um abaixo-assinado que solicitava a abertura do processo de tombamento. $O$ documento assinado por proprietários e residentes do município de Santana de Parnaíba, nos arredores da Serra do Boturuna apresentava oito fatores, ou justificativas, que conduziam ao pedido de tombamento da Serra. Esses fatores destacavam, sobretudo, a importância dos atributos físicos da Serra do Boturuna. O documento também enfatizou sobre a atuação de mineradores clandestinos na região, o que comprometeria a preservação desse maciço quartzítico.

A abertura do processo de tombamento conduziu o CONDEPHAAT a desenvolver um parecer técnico sobre a Serra. Tal parecer, elaborado pelo geógrafo, e na época presidente e conselheiro do CONDEPHAAT, Professor Doutor Aziz Nacib Ab'Sáber, destacava, sobretudo, as características geológicas e geomorfológicas da região, juntamente com uma análise preliminar da atividade minerária, conforme descrição a seguir:

Num dos setores mais elevados da Serra do Boturuna (1200m) uma exploração mineral, totalmente irracional, faz talhados profundos nas altas simeiras laterais da Serra. Por sua vez, o material de escolho é desviado por gravidade para as bordas do Pico, por ente as florestas que no passado atingiram continuamente as altas encostas da Serra. Os caminhos deixados nas áreas preferenciais de desligamento dos blocos, rejeitados pela exploração mineral, fazem estragos lineares irreversíveis no entremeio das florestas que até há pouco garantiam estabilidade nas vertentes mais elevadas da Serra. Para se explorar 
um mineral pobre, que pode ser encontrado em outras áreas de ocorrência, acabou-se por estragar parcialmente a integridade física e ecológica de uma paisagem, das mais pitorescas e características das Serranias de Jundiaí - Parnaíba - Cabreúva. (AB'SÁBER, 1982).

Apesar da menção ao principal problema ambiental da Serra do Boturuna, o parecer não apresentou uma solução técnica viável para a atividade mineral, sobretudo, para as mineradoras legalizadas que há anos exploravam os recursos minerais da Serra. De acordo com o parecer, a pressão ambiental sobre a Serra, à época, efetuava-se por meio de duas formas distintas:

De um lado a Serra está sendo pressionada pelas expectativas de alguns loteadores que não mediram esforços para tentar comerciar os íngremes espaços da Serra e do seu topo. Da outra banda, ela está sendo agredida pela destruição injustificável de alguns pontos mais característicos de sua paisagem, por explorações minerais de baixo nível de economicidade e alta capacidade de desmonte de rochas. Apesar disso tudo, os espaços da Serra propriamente dita, não pertencem a ninguém, devendo ser preservado para todo o sempre como um componente integrado da natureza tropical do Planalto Atlântico Paulista. Ninguém será prejudicado pelo seu tombamento, já que as áreas lotadas a partir dos patamares baixo e piemontes, tende a funcionar como cinturão de áreas residenciais de algo nível, em que o moradores serão os principais interessados em garantir a integridade da moldura paisagística e ecológica. (AB'SÁBER, 1982).

De forma geral, a mineração foi interpretada como um uso incompatível para a preservação da Serra, o que, certamente, é justificável, devido aos objetivos do tombamento. Entretanto, não houve o encaminhamento para a elaboração de diretrizes mínimas para a mineração na Serra e, no momento da edição da resolução, essa atividade econômica, que fora mencionada no parecer como incompatível, é autorizada com pequenas restrições.

O parecer ainda propunha alguns usos compatíveis com o estatuto do tombamento. Entre os quais:

Os loteamentos, sítios, chácaras e campins (sic) que envolvem a Serra pelo seu piemonte serão respeitadas pelo estatuto do tombamento, cabendo ao seu proprietário zelar pelo bem tombado como componente de um cinturão de defesa da Serra perante ações predatórias e atividade por ventura incompatíveis. (AB'SÁBER, 1982).

De acordo com o Parecer, as diretrizes fixadas no tombamento do Boturuna seriam similares, mas não idênticas, àquelas elaboradas pelo CONDEPHAAT para a Serra do Japi. 
Após a submissão do parecer aos conselheiros, o egrégio colegiado o aprovou por unanimidade e conduziu os procedimentos legais para a elaboração da resolução.

A resolução de tombamento descreveu os objetivos do tombamento da Serra, as tipologias de uso e ocupação do solo que eram compatíveis e a delimitação da área tombada.

A criação da ANT da Serra do Boturuna inclui o estabelecimento de contradições de natureza jurídica no ato de seu tombamento, relacionada à manutenção da atividade mineradora na Serra. Ao considerar a interpretação de Machado (2004), o Decreto-lei Federal n. 25/37, no art. 17, primeira parte, determina que as coisas tombadas não poderão, em caso nenhum, ser destruídas, demolidas ou mutiladas. Assim, a manutenção da atividade numa ANT ocorre contrariamente ao que dispõe a lei, o que institui uma antinomia jurídica por parte da resolução de tombamento. Para Machado (2007),

As florestas ou outras formas de vegetação e o solo que integrem um sítio tombado não poderão, portanto, ser destruídos pela exploração de recursos minerais, ainda que se proponha uma futura recuperação. O sítio privado ou público que for tombado merece a integral proteção naquilo que ele contém atualmente, que não pode ser modificado antropicamente, a não ser para cuidados $\mathrm{e}$ manutenção. (MACHADO, 2004, p. 638).

A resolução de tombamento não poderia conter dispositivos que contrariam as diretrizes gerais das leis superiores. Fica claro que 0 estabelecimento de mineradoras numa ANT impõe uma situação de conflito jurídico com relação à hierarquia das leis sobre essa temática. Todavia, devese considerar também que a regulamentação de uma atividade minerária inclui um Decreto de Lavra, o que pode ser interpretado, por parte dos mineradores, como um direito adquirido. Inclui-se também que tais decretos são anteriores ao processo de tombamento da Serra do Boturuna.

Observaram-se também algumas contradições entre o Decreto Estadual, que regulamenta a matéria e a resolução de tombamento da ANT da Serra do Boturuna. $\mathrm{O}$ art. 3ํ. da Resolução, por exemplo, define uma área envoltória na ANT de 300m sob discreto critério de controle de organização espacial, por parte do CONDEPHAAT. Contudo, o termo discreto deixa margem para muitas interpretações e, de certa forma, contraria o art. 137 do Decreto Estadual n. 13.426/79 que dispõe que nenhuma obra poderá ser executada nessa faixa sem o respectivo projeto aprovado pelo CONDEPHAAT. 


\section{ASPECTOS CLIMÁTICOS DA REGIÃO}

A análise dos aspectos climáticos da região da Serra do Boturuna tem o objetivo de fornecer um panorama geral de duas variáveis climatológicas: a precipitação e a temperatura. As médias mensais dessas variáveis se condicionam pela dinâmica da atmosfera, em virtude da maior atuação de determinado sistema atmosférico.

A região possui influência de sistemas extratropicais e intertropicais. Com destaque para a atuação de três sistemas atmosféricos: a Massa Polar Atlântica (MPA), a Massa Tropical Atlântica (MTA) e a Massa Tropical Continental (MTC). A MPA, que dinamiza processos frontogenéticos da Frente Polar Atlântica (FPA), possui forte influência na gênese das chuvas na região em todos os períodos do ano. Porém, apresenta relevância fundamental na ocorrência da precipitação nos meses considerados secos.

A ANT da Serra do Boturuna não possui estações meteorológicas em seu perímetro, assim, utilizou-se como referência o climatograma da estação meteorológica da Usina de Pirapora, a estação mais próxima da ANT. O climatograma da Figura 3 demonstra os valores médios mensais de precipitação e de temperatura na estação pluviométrica de Pirapora, operada pela Empresa Metropolitana de Águas e Energia S.A. (EMAE), segundo os dados da série histórica do período de 1957 a 2005. 


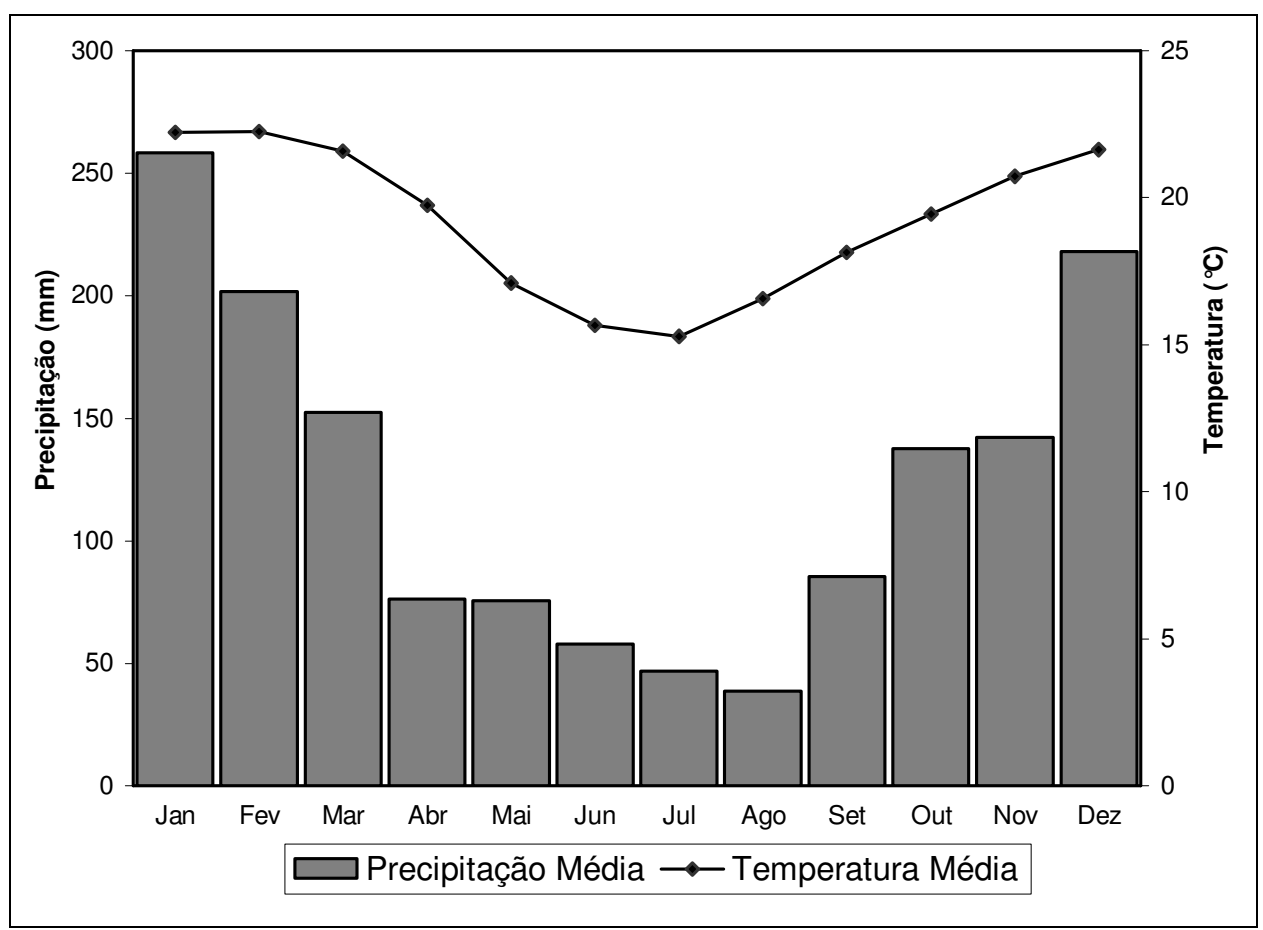

Figura 3 - Climatograma da estação pluviométrica de Pirapora (P12-237), série histórica de 1957 a 2005 (Fonte: EMAE; estimativa de temperaturas)

Observa-se que o período mais úmido concentra-se entre os meses de outubro a março. Nesse sentido, entre os meses de abril a setembro ocorre diminuição nas precipitações, com valores médios mínimos no inverno. A intensidade pluviométrica no período inverno relaciona-se à freqüência de ação da MPA e o contraste térmico das massas de ar. Essas características condicionam os invernos secos ou úmidos. Logo, as incursões da MTA no inverso caracterizam estabilidade atmosférica, devido ao efeito do resfriamento basal (MONTEIRO, 1973).

Entre os meses de novembro e de março, todas as correntes atmosféricas condicionam pluviosidade. $O$ período destaca-se pela predominância quantitativa das ondas de leste e noroeste. O aquecimento basal e a instabilização da MTA, juntamente com as perturbações frontais ocasionadas pela FPA determinam índices pluviométricos médios mensais superiores a $250 \mathrm{~mm}$. Nesse período, a FPA apresenta-se com maior umidade e dinamizada, logo, a oposição da MTA ocasiona alta intensidade das precipitações. No entanto, o enfraquecimento da MPA faz com que as chuvas, muitas vezes, relacionam-se às condições locais. 
O efeito orográfico também influencia na distribuição espacial dos índices pluviométricos. No período úmido, o avanço da MTA provoca o aumento dos valores de precipitação a barlavento. Convém destacar que a diminuição da temperatura nas maiores altitudes ocasiona a diminuição dos índices pluviométricos em função da remoção da umidade.

Os períodos intermediários, entre os meses mais secos e os mais úmidos, caracterizam-se pela diversificação da gênese das pluviosidades. $\mathrm{O}$ Mapa 3 representa a distribuição da precipitação média anual com bases nas estações meteorológicas da Tabela 6 que descreve a série histórica de 1972 a 2002. Entre as estações pluviométricas, destaca-se a de Ponunduva, em Cajamar - SP, com precipitações médias anuais acima de $2.000 \mathrm{~mm}$.

Tabela 6 - Médias históricas (1972 a 2002) das estações pluviométricas da região da Serra do Boturuna, Estado de São Paulo

\begin{tabular}{|c|c|c|c|c|c|c|c|c|}
\hline \multicolumn{4}{|c|}{ Dados da Estação Pluviométrica } & \multicolumn{5}{c|}{ Médias (mm) } \\
\hline Município & Cód. & Estação & Operadora & Alt. & $\begin{array}{c}\text { Período } \\
\text { Seco }\end{array}$ & $\begin{array}{c}\text { Período } \\
\text { Umido }\end{array}$ & Mensal & Anual \\
\hline Cajamar - SP & $\begin{array}{c}\text { E3- } \\
233\end{array}$ & Ponunduva & DAEE & 740 & 106,69 & 232,34 & 169,51 & $2.034,16$ \\
\hline $\begin{array}{c}\text { Santana de Parnaíba } \\
- \text { SP }\end{array}$ & $\begin{array}{c}\text { E3- } \\
020\end{array}$ & $\begin{array}{c}\text { Santana } \\
\text { de } \\
\text { Parnaíba }\end{array}$ & DAEE & 720 & 67,36 & 183,69 & 125,53 & $1.506,32$ \\
\hline $\begin{array}{c}\text { Santana de Parnaíba } \\
- \text { SP }\end{array}$ & $\begin{array}{c}\text { P12- } \\
108\end{array}$ & $\begin{array}{c}\text { Barragem } \\
\text { Edgard de } \\
\text { Souza }\end{array}$ & EMAE & 719 & 63,32 & 179,17 & 121,25 & $1.454,96$ \\
\hline $\begin{array}{c}\text { Pirapora do Bom } \\
\text { Jesus - SP }\end{array}$ & $\begin{array}{c}\text { P12- } \\
115\end{array}$ & $\begin{array}{c}\text { Usina de } \\
\text { Rasgão }\end{array}$ & EMAE & 651 & 70,12 & 188,02 & 128,54 & $1.542,51$ \\
\hline $\begin{array}{c}\text { Pirapora do Bom } \\
\text { Jesus - SP }\end{array}$ & $\begin{array}{c}\text { P12- } \\
237\end{array}$ & Pirapora & EMAE & 698 & 69,15 & 187,94 & 129,07 & $1.548,84$ \\
\hline
\end{tabular}

Fonte: EMAE, DAEE

Devido à indisponibilidade de estações com sensor de temperatura, obtiveram-se os valores médios mensais de temperatura por meio da Estimativa das Temperaturas Médias Mensais do Estado de São Paulo em Função de Altitude e Latitude (PINTO, ORTOLANI; ALFONSI, 1972). Os valores decorrem de cálculos de regressão múltipla para todos os meses e baseiam-se no método dos quadrados mínimos.

De acordo com os autores, o resultado do trabalho sugere que as variações de temperatura no Planalto Paulista, realmente, ocorrem em função de latitude e altitude. Confirmou-se essa hipótese por meio do o coeficiente de determinância $\left(R^{2}\right)$. 


\section{Mapa 3 - Precipitação Média Anual (1972 a 2002) na Região da ANT da Serra do Boturuna, Estado de São Paulo}

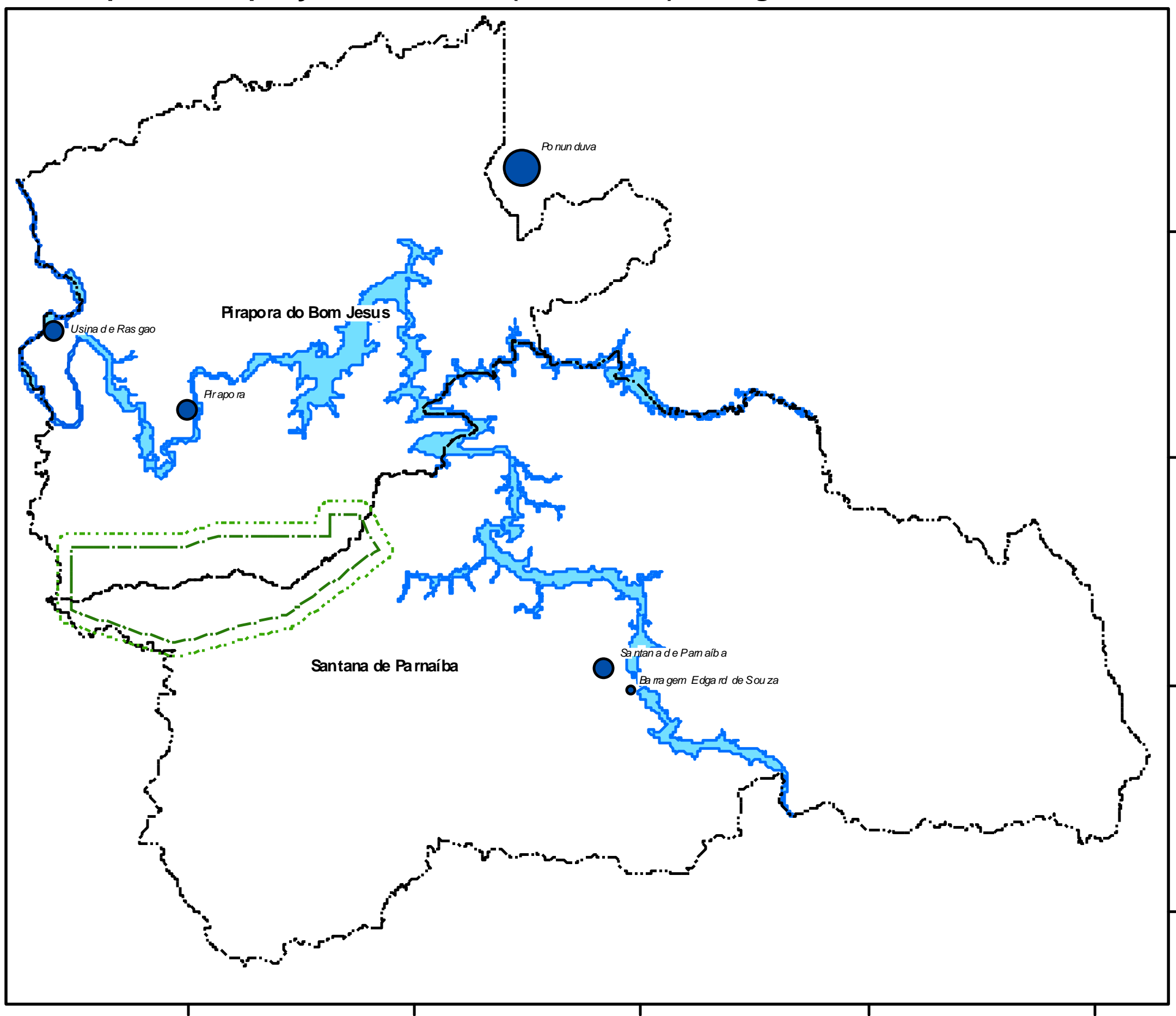

Convenções Cartográficas

Curso dágua

53 Reservatório

[.......... L Limite municipal

ANT da Serra do Boturuna ....... Limite 300m da ANT

Precipitação Média Anual

- $\quad 1.416$ a $1.500 \mathrm{~mm}$

O $1.501 \mathrm{a} 2.000 \mathrm{~mm}$

2001 a $2.034 \mathrm{~mm}$

Projeção Universal

Tranversa de Mercator (UTM) Elipsóide: SAD-69

Datum Horizontal: $S A D-69$

Meridiano Central: $-45^{\circ}$ Grw.

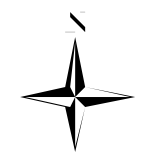

1:118.000

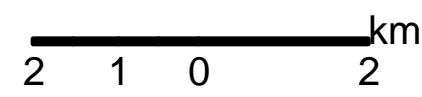

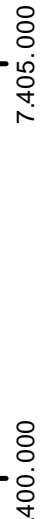

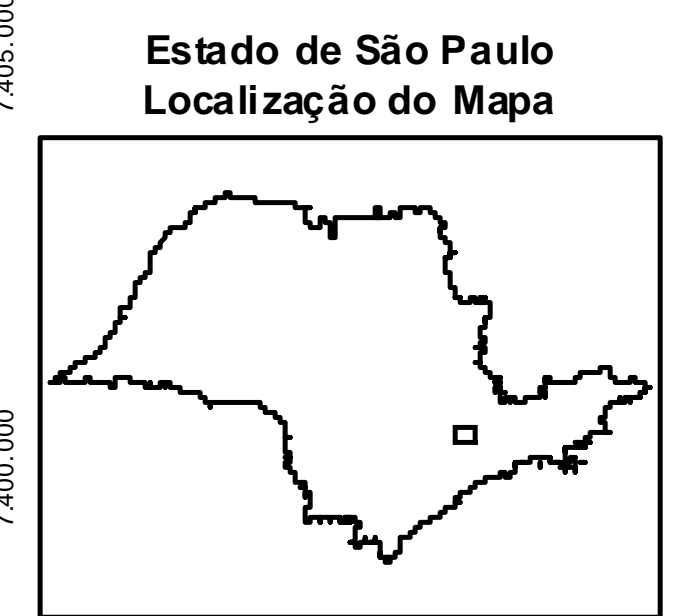

Fonte: EMAE DAEE, ANA

Eab. por: Sa norr F. Detoni (20 08) 
Nos meses de julho, observou-se o menor $\mathrm{R}^{2}$, atribuiu-se que por volta de $74 \%$ da variação da temperatura nesse mês relacionava-se à altitude e à latitude; assim, apenas $26 \%$ relacionavam-se a outros parâmetros. No entanto, a comparação com dados oficiais demonstrou que, muitas vezes, essa diferença condiciona-se à má localização de algumas estações meteorológicas, que possuem influência dos efeitos topoclimáticos.

Os cálculos efetuados para a estação pluviométrica de Pirapora, que se encontra numa altitude de $698 \mathrm{~m}$, sugerem uma temperatura média no mês mais quente de $22,2^{\circ} \mathrm{C}$ e, no mês mais frio, de $15,27^{\circ} \mathrm{C}$. Como a Serra do Boturuna, encontra-se numa altitude superior a $1.000 \mathrm{~m}$, supõe-se que esses valores médios mensais sejam menores.

No contexto geral, a região da Serra do Boturuna possui verão com média de temperaturas amenas com predomínio de altos índices pluviométricos. Caracteriza-se o inverno como frio e seco. Com base na análise das médias históricas, sugere-se que a região possua características de clima tropical sem estação seca. Porém, o estabelecimento da estação seca depende dos avanços da MPA, logo, o período caracterizado como seco perdura de um a dois meses. Se considerado o Sistema Internacional de Classificação de W. Köppen, a região apresenta características de clima temperado com inverno menos seco (Cfb).

\section{SOLOS NA ANT DA SERRA DO BOTURUNA}

Os aspectos pedológicos possuem fundamental importância na distribuição das tipologias vegetacionais na ANT da Serra do Boturuna. A topografia e a litologia condicionam a ocorrência das tipologias de solo, pois definem as características químicas e físicas do perfil pedológico. Dentre os aspectos físicos do solo destacam-se: a textura, a estrutura, a plasticidade, o grau de coesão de suas partículas e a profundidade (espessura) dos horizontes superficiais e subsuperficiais. Além de diferenciar o tipo de solo, essas características definem o seu grau de erodibilidade, sendo um importante parâmetro para definir as suscetibilidades do ambiente. 
Os solos bem drenados, porosos e profundos com horizonte B latossólico, que caracteriza uma distribuição homogênea de argila no perfil (mais argilosos), possuem baixa erodibilidade. Com relação à topografia, esses solos tendem a ocorrer em relevos que variam de ondulado a suave ondulado.

A variação granulométrica e a distribuição de argila no perfil pedológico determinam o aumento da erodibilidade do solo. Assim, os solos que apresentam horizonte B textural, por exemplo, possuem maior suscetibilidade aos processos erosivos, pois o horizonte $B$ apresenta maior quantidade de argila em relação ao horizonte $A$. Os solos com horizonte $B$ textural tendem a ser encontrados em relevos mais montanhosos, o que favorece o transporte de argila no perfil pedológico.

Os solos rasos, arenosos e com ausência de horizonte B apresentam altos índices de erodibiliade, ou seja, são mais suscetíveis aos processos erosivos. Nessa categoria, incluem-se os solos predominantes nas maiores altitudes do no maciço quartzítico do Boturuna.

Os diferentes graus de suscetibilidade dos solos aos processos erosivos também se relacionam à tipologia do escoamento superficial. Segundo Ross (1994), deve-se ponderar quanto ao escoamento superficial difuso e ao concentrado. Um escoamento concentrado pode ocasionar maior erodibilidade em solos com horizonte $B$ latossólico do que em solos com horizontes B textural.

A região da ANT da Serra do Boturuna não possui uma caracterização pedológica detalhada. Contudo, a relação entre o relevo e a litologia se constituiu na base elementar para a diferenciação das principais tipologias de solo na ANT.

No mapeamento dos solos do Estado de São Paulo realizado pelo IAC/EMBRAPA (OLIVEIRA, et al., 1999) na escala 1: 500.000, identificou-se, de forma muito generalista, como solo predominante na região da ANT da Serra do Boturuna o Argissolo Vermelho-Amarelo (PVA-42). Essa nomenclatura confere a esse tipo de solo o caráter distrófico com textura argilosa, encontrado em relevo forte ondulado ou montanhoso.

De acordo com esse levantamento, as áreas de relevo montanhoso e escarpado, associam-se aos Cambissolos Háplicos distróficos com textura 
argilosa. Essas duas tipologias de solos possuem horizontes superficiais "A" moderado.

Ross e Moroz (1997) identificaram para o Planalto de Jundiaí, compartimento geomorfológico onde se localiza a região da Serra do Boturuna, os seguintes solos: Cambissolos, Podzólicos (Argissolos) Vermelho-Amarelos com textura média arenosa, Latossolos Vermelho-Amarelo com textura média arenosa e Areias Quartzosas (Neossolos Quartzarênicos).

Ao detalhar a escala de análise, é possível afirmar que os níveis morfológicos, as declividades e o embasamento litológico são os principais condicionantes da distribuição das tipologias pedológicas da região da ANT. Logo, a complexidade litológica e as diferenças topográficas fazem com que os solos da região se caracterizem por associações, exceto nas altas declividades com embasamento quartzítico e no topo da Serra do Boturuna, conforme descrito na caracterização dos solos apresentada no PRAD da Mineradora Lolli.

O maciço quartzítico do Boturuna se caracteriza pela ocorrência de Afloramentos Rochosos e dos Neossolos Litólicos, condicionados pela alta declividade (acima de $30 \%$ ) e pela pequena profundidade do perfil pedológico. A matriz litológica desses solos varia conforme a rocha predominante (o quartzito e o filito). Destaca-se que o quartzito na Serra do Boturuna possui estrutura laminar com intercalações de filitos. Com nível morfológico acima dos $900 \mathrm{~m}$, os Afloramentos Rochosos e os Neossolos Litólicos influenciam a estrutura pedológica do entorno. Entretanto,

[...] os terrenos tidos como proterozóicos, pertencentes às séries metamórficas, em geral dão origem a solos paupérrimos, tanto do ponto de vista químico, quanto ao seu comportamento físico. As massas de quartzitos da série São Roque, assim como as extensas faixas de filitos dessa mesma série cristalofiliana paulista, dão origem a solos extremamente pobres, incapazes de suportar atividades agrícolas demoradas e impróprios até mesmo para se transformarem em pastos. Daí a maior parte deles ter sido relegados a um reflorestamento na base de eucaliptos, que é uma das raras espécies vegetais capazes de se enraizar e viver no meio desses solos. Deve-se observar que, no interior da própria área geográfica da série São Roque, há ilhotas de solos bastante aproveitáveis, representados principalmente por alguns calcáreos metamórficos e anfibolitos. (AB'SÁBER, 2004, p. 44).

Devido à complexidade litológica e ao aporte de materiais entre os níveis morfológicos, a distribuição dos solos das áreas subjacentes ao maciço quartzítico caracteriza-se por associações pedológicas (LOLLI, 2004). 
.A associação entre Latossolo Vermelho-Amarelo e Argissolo VermelhoAmarelo ocorre, sobretudo, nas declividades entre 12 e $24 \%$ e num nível morfológico que varia de $700 \mathrm{~m}$ até $900 \mathrm{~m}$, sendo subseqüente ao grupo de solos do maciço quartzítico. As cores mais avermelhadas desses solos indicam a ocorrência de ferro.

O Latossolo Vermelho-Escuro associado ao Latossolo VermelhoAmarelo se distribui nas áreas com declividades entre seis e $12 \%$, o que corresponde a um nível morfológico de até $700 \mathrm{~m}$. A matriz litológica desses solos se compõe de ferro, assim, a cor vermelha indica o teor de ferro.

O Argissolo Vermelho-Amarelo em associação com o Latossolo Vermelho-Amarelo ocorre em relevo ondulado e áreas mais montanhosas, porém, com características litológicas especificas. Num contexto mais amplo, essa tipologia de solo encontra-se em áreas de embasamento litológico composto por anfibolitos.

Há também pequenos setores com Neossolos Flúvicos (Solos Aluviais). Entretanto, a estrutura geomorfológica da região faz com que essa tipologia de solo seja menos comum.

Apesar da distribuição pedológica diferenciada, a característica fundamental de grande parte dos solos da região da ANT da Serra do Boturuna, advém do caráter distrófico, pobres em nutrientes e com elevada acidez, tais propriedades condicionaram a distribuição dos compartimentos de vegetação na Serra.

\section{VEGETAÇÃO NA ANT DA SERRA DO BOTURUNA}

Conforme descrito, a distribuição da vegetação na região da Serra do Boturuna condiciona-se aos fatores climáticos, aos geomorfológicos, aos pedológicos, aos litológicos e, sobretudo, à influência antrópica.

De acordo com a classificação proposta por Ab'Sáber (2003), a Serra do Boturuna localiza-se no Domínio Morfoclimático dos Mares de Morros. O autor utiliza o termo morfoclimático para destacar o caráter sistêmico da paisagem. Entretanto, em cada domínio morfoclimático, há um sistema de inter-relação entre os componentes morfológicos, pedológicos, climáticos e vegetacionais. 
Esses fatores associados compõem, assim, uma determinada fisionomia de paisagem.

No Domínio Morfoclimático dos Mares de Morros, o relevo, que é caracterizado pelo planalto, juntamente com a atuação de sistemas atmosféricos, determinam uma tipologia geomorfológica e climática do domínio em questão. De forma geral, o relevo e o clima também condicionam a fitofisionomia predominante nesse domínio, o que constitui, mais amplamente, uma cobertura vegetal de Mata Atlântica. Todavia, há distintas características locais que podem condicionar a distribuição desse tipo florestal.

O macro-compartimento geomorfológico do Domínio Morfoclimático dos Mares de Morros é o Planalto Atlântico. Entretanto, constata-se que o padrão de distribuição da vegetação não ocorre de forma homogênea e apresenta alguns compartimentos diferenciados, em virtude dos condicionantes locais, fato também observado na distribuição dos compartimentos geomorfológicos. De acordo com o Mapa de Vegetação do Brasil (IBGE, 2004), no Planalto Atlântico, há o predomínio da Floresta Ombrófila Densa. O termo ombrófila caracteriza a ausência de um período seco ou, quando ocorrer, envolve dois meses. O critério para a elaboração desse mapa considerou a distribuição fitoecológica pautada na disponibilidade de água, na tipologia dos solos e no clima. Entretanto, supõe-se que em algumas áreas do Planalto Atlântico, a vegetação original fosse formada por campos naturais, por exemplo, nos terrenos Cenozóicos como os da Bacia Sedimentar de São Paulo. Essa característica peculiar está relacionada, em especial, aos solos da região.

Além da floresta ombrófila densa e dos campos naturais, é possível identificar alguns enclaves de cerrado e até mini-enclaves de cactáceas, que se relacionam à hipótese de fatores paleoclimáticos e paleogeográficos.

Por meio de um maior detalhamento da escala, é possível destacar distintas formações florestais, cuja distribuição se relaciona à atividade climática, ou às condições pedológicas impostas. Nesse sentido, de acordo com o critério da sazonalidade e com base nos critérios de classificação climática do IBGE (2004), a área de estudo pode ser classificada como Floresta Estacional Semidecidual, sendo possível observar na região duas tipologias climáticas: uma fria e seca e outra quente e úmida. A característica estacional decorre do déficit hídrico da estação fria e seca, caracterizada pela queda das 
folhas de algumas espécies florestais. Logo, as tipologias florestais identificadas na região compõem-se por espécies decíduas e semidecíduas ${ }^{16}$. Além desses fatores, a estrutura topográfica ainda permite inserir a área de estudo no grupo de formações vegetais Montana ${ }^{17}$. Porém, não há homogeneidade nesse tipo florestal, pois a distribuição da vegetação condiciona-se, sobretudo, aos aspectos pedológicos.

A Floresta Estacional Semidecidual Montana, não possui uma formação florestal tão fechada, conseqüentemente, não forma uma camada contínua de vegetação (IBGE, 2004). A altitude e as características dos solos fazem com que determinadas áreas da Serra do Boturuna possuam características fisionômicas da vegetação próximas a um campo de altitude ou algo muito semelhante a um campo cerrado. É possível também verificar um gradiente vegetacional entre sopé e o topo da Serra (Figura 4).

A florística das florestas de altitude apresenta diferenças quantitativas e qualitativas em relação às florestas de regiões mais baixas, com algumas espécies exclusivas e outras que demonstram claras preferências por ambientes mais altos. Estas condições são basicamente representadas por solos mais pobres e ácidos, fortemente erodidos, no geral bem mais rasos e presença muito freqüente de densos nevoeiros. (LEITÃO-FILHO, 1992, p. 45).

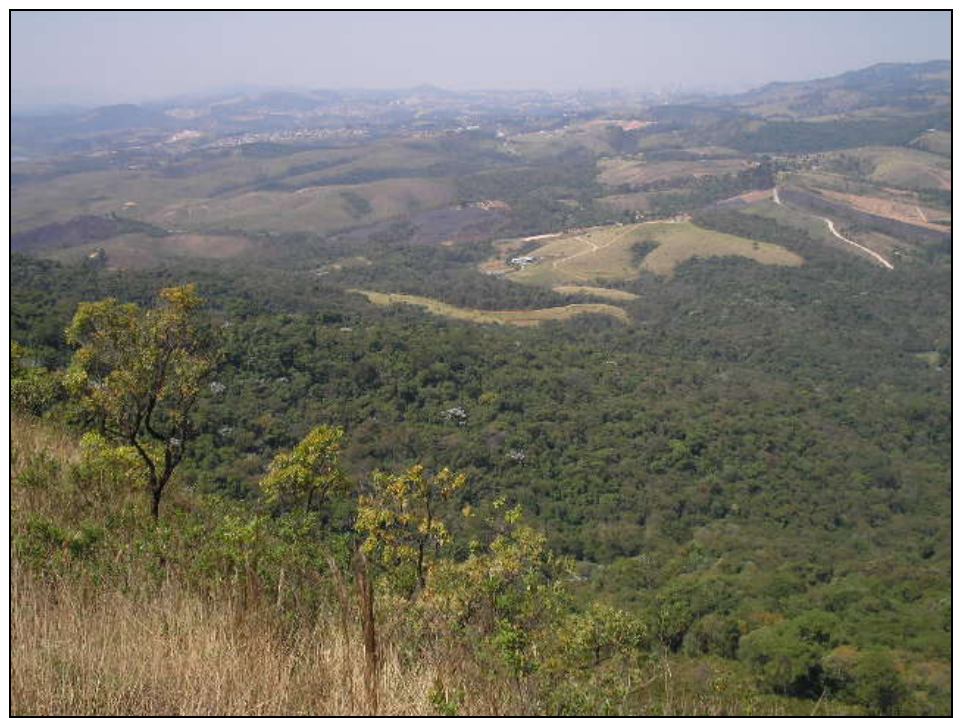

Figura 4 - Gradiente vegetacional da região da Serra do Boturuna (Sandro F. Detoni, setembro de 2006)

\footnotetext{
${ }^{16}$ As espécies semidecíduas perdem 20 a 50\% das folhas no período seco (IBGE, 2004).

${ }^{17} \mathrm{O}$ grupo de formação vegetacional Montana, entre as latitudes $16^{\circ}$ e $24^{\circ}$, caracteriza-se por altitudes entre 500 e $1.500 \mathrm{~m}$.
} 
Observou-se a ocorrência de algumas espécies típicas de cerrado, sobretudo, nas áreas onde solo advém do embasamento quartzítico. Tal fato conduz a hipótese que essa fisionomia vegetal condiciona-se a baixa disponibilidade nutricional dos solos, características de primeira grandeza na cobertura pedológica na Serra do Boturuna.

As deficiências nutricionais impediriam a síntese de proteínas a partir dos carboidratos, os quais tenderiam a se acumular nas plantas do cerrado que, não tendo água, luz, $\mathrm{CO}_{2}$, nem outros fatores limitando a fotossíntese, os sintetizariam em excesso sobre o que seria consumido por respiração ou por crescimento. Tal excesso é que seria utilizado nas estruturas que dão à planta os aspecto xeromorfo e que, freqüentemente é devido à falta de água. No caso dos cerrados, porém, esse xeromorfismo, que não é devido à falta de água (em geral, é um falso xeromorfismo, devido à escassez de nutrientes no solo). Trata-se, muitas vezes, de escleromorfismo oligotrófico. (FERRI, 1979, p.35).

O grau de fertilidade dos solos e sua influência sobre a disponibilidade de nutrientes para as plantas do cerrado advêm da combinação de distintos fatores. Assim, a característica oligotrófica dos solos do cerrado resulta de sua acidez e das suas altas concentrações de alumínio, o que produz uma deficiência mineral. Além dos solos pobres em nutrientes formados a partir dos quartzitos, verifica-se na Serra do Boturuna áreas onde o embasamento compõe-se de rochas calcárias. As concentrações de alumínio dessas rochas, possivelmente, favoreceram o estabelecimento de espécies vegetais de cerrado. A hipótese da ocorrência de fitofisionomias semelhantes à do cerrado no topo da Serra do Boturuna se fundamenta na seguinte descrição:

Formação de fisionomia peculiar caracterizada por apresentar indivíduos de porte atrofiado (que podem atingir aproximadamente 6 metros de altura), enfezados, de troncos retorcidos (tortuosos), cobertos por casca espessa e fendilhada, de esgalhamento baixo e copas assimétricas, folhas na maioria grandes e grossas, algumas coriáceas, de cules e ramos encortiçados, com ausência de acúleos e espinhos, bem como epífitas e lianas. (SÃO PAULO, 2005, p. 14).

Destaca-se que a Serra do Boturuna apresenta características de um campo cerrado, que se constitui em campos com pequenas árvores e arbustos esparsos, disseminados num substrato graminóide (SÃO PAULO, 2005).

Os solos formados em arenitos, em xistos e em outras rochas sedimentares, sob condições de lixiviação, ou seja, que contribui para a mobilidade da sílica, tendem a favorecer o estabelecimento dos cerrados. No entanto, os aspectos pedológicos necessitam de acondicionamento de fatores que inibem ou acionam outros fatores numa reação cíclica. 
Existe um considerável grau de interação entre os fatores, dentre os quais tanto há aqueles que acionam outros fatores quanto aqueles que os inibem. Ademais, as plantas apresentam uma reação que se prende mais ao conjunto dos fatores do que propriamente a um desses fatores em si. (GOODLAND, 1979, p. 142).

Nesse sentido, para Goodland (1979), a aplicação da hipótese do xeromorfismo aluminotóxico nos solos de cerrado depende de alguns fatores: os solos devem ser ácidos para que o alumínio esteja presente sob a forma iônica sólida com alta lixiviação, que permitirá o acúmulo de alumínio iônico em quantidade móvel e fará com que os solos do cerrado sejam pobres em nutrientes. O autor ainda destaca que, mormente, os cerrados ocorrem em latossolos vermelhos submetidos a profundo intemperismo, sendo solos profundos, uniformes, ácidos, pobres em bases trocáveis e ricos em óxidos de alumínio e ferro.

Encontram-se esses aspectos em muitos setores na região da Serra do Boturuna. É possível destacar que o gradiente de vegetação varia conforme a altitude e o tipo solo. No topo da Serra, verificou-se uma fisionomia das paisagens que mistura elementos de campos de altitude e do cerrado. Tornase necessário um melhor detalhamento do ambiente, pois a atividade antrópica na Serra foi muito intensa. Todavia, nas áreas recobertas por vegetação rasteira, notou-se uma ampla cobertura de samambaias, o que indica a alta acidez daqueles solos. Por isso, deve-se destacar que nas áreas elevadas da Serra, os solos apresentam-se como distróficos, com pH baixo, o que sugere maiores teores de alumínio e maior acidez.

No topo da Serra, também verificou a ocorrência de grotões de vegetação mais densa e áreas de turfeira, semelhantes a brejos. Ab'Sáber (1992) interpreta que os brejos sugerem a coexistência regional das caatingas com as matas (refúgios de florestas tropicais).

A Figura 5 demonstra uma espécie típica de cerrado encontrada no topo da Serra, a Bowdichia virgilioides (Leguminosae-Papilionoideae), conhecida como sucupira-do-cerrado, ou sucupira-do-campo, caracterizada por ser uma espécie típica de cerrado. "A família das Leguminosae é tão importante para vegetação quanto para a flora. A quarta árvore mais importante é a leguminosa Bowdichia." (GOODLAND, 1979, p. 62). Essa espécie ocorre em todos os tipos de cerrado e seu aspecto fisionômico varia conforme o tipo de cerrado, ou seja, condiciona-se a disponibilidade de nutrientes. 
Trata-se no cerradão de uma grande árvore, e no campo sujo de uma arvoreta. Apresenta uma \% de ocorrência mais ou menos idêntica em todos os tipos de cerrado. Esta versatibilidade é demonstrada por seu vasto âmbito geográfico, visto que esta espécie constitui um dos vegetais mais importantes entre os das savanas do México, da América Central e das Guianas, os dos "llanos" da Colômbia e da Venezuela e os da maior parte das áreas de cerrados do Brasil. Além do mais, trata-se de apreciada madeira de lei nas florestas existentes dentro da sua área de ocorrência. (GOODLAND, 1979, p. 85).

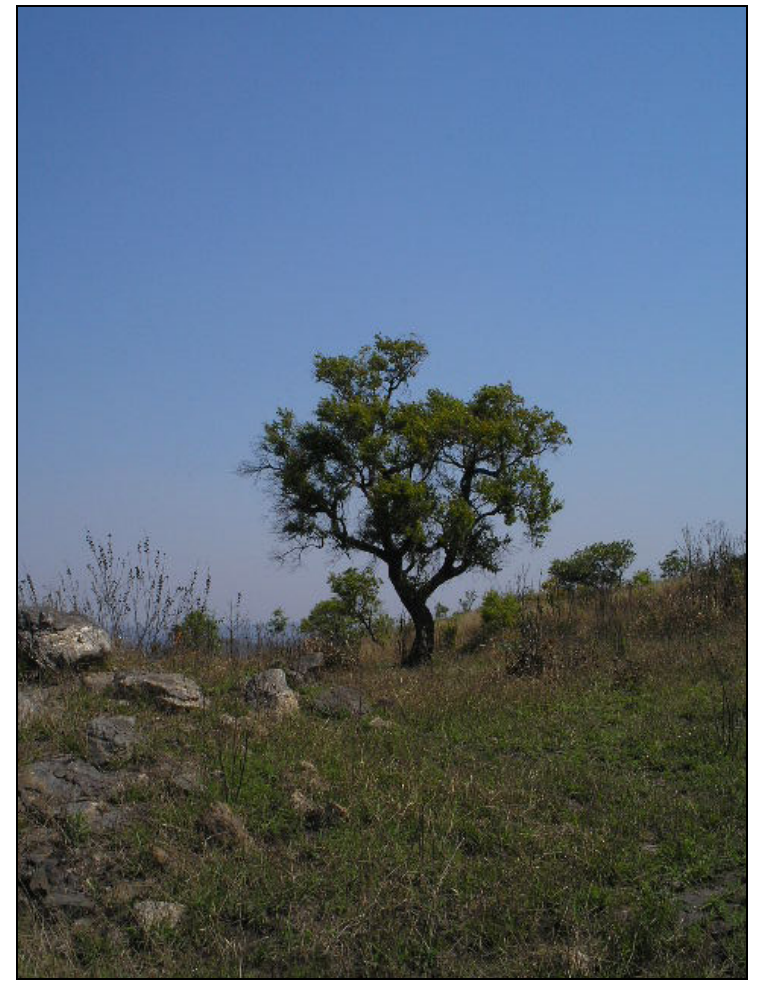

Figura 5 - Bowdichia virgilioides (Leguminosae-Papilionoideae) no topo da Serra do Boturuna (Sandro F. Detoni, setembro de 2006)

Os aspectos descritos demonstram a complexidade vegetacional na Serra do Boturuna. Por isso, a resolução de tombamento dispõe que os remanescentes florestais fazem com que a região possua caráter de refúgio forçado da natureza tropical. Além dessa característica, talvez seja possível identificar, nessa região, mini-enclaves de cactáceas, pois ela possui uma estrutura paisagística de certa forma com alguma similaridade à da Serra do Japi. Ao se considerar a corrente teórica dos refúgios, esse ecossistema também poderia ser encontrado nas maiores altitudes da Serra. Cabe ressaltar que por causa da semelhança da estrutura paisagística com a Serra do Japi pressupõe-se a existência dessa formação vegetacional na região, sendo 
necessário um levantamento de campo mais detalhado para a confirmação dessa hipótese. Porém, o forte desmatamento que ocorreu, sobretudo, nas vertentes orientadas para o norte da Serra do Boturuna, talvez possa dificultar essa identificação.

Considerado um ecossistema especializado, a suposta presença de coberturas vegetais adaptadas a determinadas condições de equilíbrio relaciona-se à atuação no último período glacial de clima seco.

Ab'Sáber (2003), ao seguir o princípio da teoria dos redutos florestais, denomina esses enclaves como rupestrebioma ${ }^{18}$. Já Bertand (1968) utiliza a terminologia geótopo em virtude do tamanho da escala de análise.

O recuo florestal, com a atuação de climas secos, combinado com as características paleogeográficas, propiciou a expansão desse tipo de vegetação na região. A atuação de climas úmidos permitiu a re-expansão das florestas. Porém, os enclaves foram mantidos em virtude das características altimétricas, litológicas e pedológicas da Serra do Boturuna. Para Ab'Sáber (2003),

[...] as "ilhas" de vegetação exóticas encontradas dentro das áreas core dos diferentes domínios morfoclimáticos e geobotânicos só podem ser explicadas pela existência local de fatores de exceção, de ordem litológica, hidrológica, topográfica e paleobotânica. (AB'SÁBER, 2003, p. 28).

Ab'Sáber (2003) estabelece o conceito de área core para definir uma área nuclear onde há um arranjo integrado de feições de relevo, tipos de solos, formas de vegetação e condições climático-hidrológicas que formam um complexo, até certo ponto, homogêneo e extensivo. Essa área serve de suporte para a definição de distintos domínios morfoclimáticos. Porém, questiona-se o seguinte aspecto:

O problema que se propõe, a partir de uma discussão iniciada por Jean Tricart, é os de se saber qual a correlação ecológica mais provável: o "chão pedregoso" teria siso recoberto por vegetação arbustiva de caatingas ou por uma cobertura de cerrados naturalmente degradados? (AB'SÁBER, 1992, p. 19).

Como a sazonalidade das precipitações no cerrado e na caatinga possuem características muito semelhantes, o fato que se coloca para a ocorrência de um ou de outro ecossistema advém da regularidade e da quantidade de precipitação (AB'SÁBER, 1992). Entretanto, ao partir do

\footnotetext{
${ }^{18}$ Cabe observar que o termo bioma é utilizado numa escala de análise global.
} 
pressuposto teórico que a ocorrência de cerrado relaciona-se, principalmente, às condições edáficas, sugere-se como cobertura original primitiva da Serra do Boturuna o mosaico de cerrados com campos rupestres.

O embasamento quartzito ajuda a compreender o caráter peculiar da vegetação em determinados setores do Planalto Atlântico. Essa característica condiciona a existência de determinadas especificidades regionais na cobertura da vegetal da Serra do Boturuna e do Japi.

O fato de dominarem quartzitos no conjunto do Japi, comportando exposições rochosas quase extensivas nas cimeiras e encostas mais íngremes, dificultou 0 desenvolvimento de coberturas vegetais extensivas no topo aplainado da Serra. A incidência de climas subúmidos - de subquentes a temperados - na cimeira do pequeno maciço, incluindo retenção de águas em résteas de solos, tornou possível a permanência de relictos descontínuos de matas. Um tipo de floresta Montana nem muito densa, nem muito alta, entremeada ou envolvida por manchas de campos rupestres. Nos setores mais rochosos ou sub-rochosos ocorriam cactáceas no entremeio dos campos ou em vazios ou clareiras intersticiais das matas secas. (AB'SÁBER, 1992, p. 21).

A caracterização da vegetação na Serra do Boturuna permite aferir importantes argumentos para a preservação da paisagem desse nível morfológico diferenciado. Os solos rasos com baixas quantidades de nutrientes dificultam o estabelecimento da cobertura vegetal. Todavia, as áreas com cobertura vegetal preservada se encontram na condição de equilíbrio paisagístico, pois as características pedológicas impõem que os nutrientes absorvidos pelas espécies vegetais retornem ao solo por meio da serapilheira e são solubilizados pela ação dos decompositores. Os nutrientes tendem a se concentrarem na camada superficial do solo o que caracteriza uma ciclagem rápida e superficial.

O seu solo pobre, raso e pedregoso, é instável e a vegetação depende, para a sua nutrição, de uma fina camada de raízes superficiais. A ciclagem rápida de nutrientes significa que a retirada da floresta nativa resultará em uma paisagem pobre e depauperada, dominada por pastagens. (MORELLATO, 1992, p. 106).

$\mathrm{Na}$ Serra do Boturuna, as características descritas encontram-se nas vertentes orientadas para o norte. A retirada da cobertura vegetal ocasionou 0 desequilíbrio ambiental dessas áreas que se constituem, atualmente, por pastagens degradadas. Logo, o restabelecimento de uma cobertura vegetal mais densa de porte arbóreo torna-se muito restritivo, devido às características do meio físico. 


\section{USO E OCUPAÇÃO DO SOLO NA ANT DA SERRA DO BOTURUNA E ZONA DE AMORTECIMENTO DE 300M}

O pressuposto fundamental do tombamento natural da Serra do Boturuna vincula-se, principalmente, à proteção do nível morfológico regional, juntamente com sua estrutura litológica. Entretanto, a resolução de tombamento também dispõe que essas características condicionam solos pobres e densas florestas de encostas fragilmente implantadas, entre outros recursos naturais. Dessa forma, o instrumento jurídico constituído também atende às necessidades da preservação desses remanescentes de vegetação.

Nessa etapa do trabalho, verificou-se a eficácia ou influência do ato jurídico imposto pela resolução de tombamento, principalmente, sobre a cobertura vegetal. Para isso, analisaram-se os dados sobre a evolução do uso e ocupação do solo e da cobertura vegetal na ANT da Serra do Boturuna e sua área de amortecimento de $300 \mathrm{~m}$ em dois períodos.

A análise baseou-se nos mapeamentos de uso e ocupação do solo referente aos anos de 1986 e de 2002 efetuados pela EMPLASA. Optou-se por estruturar a legenda conforme o mapeamento de 2002. No entanto, convém destacar que se efetuou uma nova interpretação das imagens do Satélite Ikonos com o intuito de ajustar o produto cartográfico aos objetivos da pesquisa.

Os dados adquiridos por tais mapeamentos foram manipulados num Sistema de Informação Geográfica (SIG), no qual se geraram as informações qualitativas sobre a evolução do uso do solo e da cobertura vegetal para a ANT.

\subsection{EM 1986}

Para verificar as principais mudanças, principalmente, na cobertura vegetal, após o estabelecimento do tombamento natural da Serra, partiu-se da análise do uso e ocupação do solo de 1986 na ANT da Serra do Boturuna e no perímetro de $300 \mathrm{~m}$, que corresponde à zona de amortecimento. Para isso, utilizou-se o levantamento do uso e ocupação do solo da grande São Paulo, 
elaborado pela EMPLASA, baseado interpretação de fotografias aéreas na escala 1: 10.000, em recobrimento aerofotogramétrico realizado em 1986/89 pela Terra Foto Aerolevantamentos.

Deve-se destacar que, na elaboração desse mapeamento, a EMPLASA compilou diversas fontes para a obtenção dos conceitos das categorias de uso e ocupação do solo. Contudo, as bases conceituais fundamentais constituíramse pelo Levantamento da Cobertura Vegetal Natural e do Reflorestamento no Estado de São Paulo ${ }^{19}$, realizado em 1974, e pelos trabalhos realizados pela pesquisadora Dora de A. Romariz ${ }^{20}$.

O Quadro 1 apresenta as categorias presentes no mapeamento de uso e ocupação do solo e cobertura vegetal da ANT da Serra do Boturuna. Posteriormente, efetuou-se a análise conceitual das categorias relacionadas à cobertura vegetal.

Quadro 1 - Classes de Uso e Ocupação do Solo do Mapeamento de 1986

\begin{tabular}{|c|}
\hline Categorias de Uso e Ocupação do Solo \\
\hline Mata \\
\hline Capoeira \\
\hline Campo \\
\hline Campo Sujo \\
\hline Reflorestamento \\
\hline Hortifrutigranjeiro \\
\hline Movimento de Terra/Solo Exposto \\
\hline Chácara \\
\hline Área Urbanizada \\
\hline Loteamento Desocupado \\
\hline Mineração Em Atividade \\
\hline Mineração Abandonada \\
\hline
\end{tabular}

Fonte: Adaptado de EMPLASA (1986)

\subsubsection{Mata}

O critério de interpretação das áreas de matas considerou a junção de distintas conceituações. Segundo a classificação da UNESCO (1973), refere-se

\footnotetext{
${ }^{19}$ SERRA FILHO, R. et al. Levantamento da Cobertura Vegetal Natural e do Reflorestamento no Estado de São Paulo. São Paulo: Instituto Florestal, 1971. 53 p. BoletimTécnico do Instituto Florestal n. 11.

${ }^{20}$ Informações adquiridas por meio de pesquisas realizadas nos arquivos da EMPLASA. Destaca-se o seguinte trabalho: Reconhecimento de Alguns Padrões de Vegetação nas Áreas das Bacias Hidrográficas Referentes às Represas Billings e Guarapiranga, elaborado em 1974.
} 
ao tipo de vegetação constituído por árvores de porte superior a cinco metros cujas copas se toquem (no tipo mais denso) ou que propiciem uma cobertura de, pelo menos, $40 \%$ (nos tipos mais abertos). No entanto, esse conceito é muito amplo e envolve os diversos tipos de matas, sendo importante um detalhamento.

No Levantamento da Cobertura Vegetal Natural e do Reflorestamento no Estado de São Paulo, o conceito de mata refere-se à formação vegetal inteiramente dominada por árvores de estrutura complexa, que apresenta grande riqueza de espécies e que possui três estratos distintos:

- Estrato superior: relativamente pouco denso é formado por indivíduos de 15 a $20 \mathrm{~m}$ de altura de troncos cilíndricos e com esgalhamento médio a alto;

- Estrato intermediário: com alta densidade é constituído por indivíduos de 10 a 15m com copas mais fechadas;

- Estrato inferior: constituído por ervas e arbusto de até três metros de altura.

Romariz definiu quatro padrões de matas: tipos 1, 2, 8 e C. O padrão de mata proposto para o mapeamento de 1986 enquadra-se no tipo 1 e 2 . No padrão do tipo 1, as copas das árvores formam um dossel bastante fechado, 0 que propicia uma cobertura superior a $80 \%$. Esse tipo de mata, também apresenta um estrato arbóreo mais baixo e, por vezes, até um arbustivo, o que faz com que a cobertura vegetal torne-se mais densa. Nas matas do tipo 2, as copas das árvores mais altas não formam um dossel tão fechado, quanto às do tipo 1, o que permite a passagem de maior quantidade de luz. No geral, a cobertura florestal varia entre 50 a $60 \%$ e até $80 \%$. As árvores são superiores a $10 \mathrm{~m}$, mas seus troncos, em média, possuem um diâmetro entre 20 e $40 \mathrm{~cm}$. A maior incidência de luz faz com que ocorra o desenvolvimento de estratos arbustivos e subarbustivos.

\subsubsection{Capoeira}

De acordo com Ab'Sáber (1978), as capoeiras e os capoeirões são termos utilizados na linguagem rural Paulista, sendo uma herança do tronco 
indígena tupi. Esses termos significam matas em recomposição e possuem relação com o longo período de pousio em solos agrícolas. A capoeira, segundo o Levantamento da Cobertura Vegetal Natural e do Reflorestamento no Estado de São Paulo, é definida como uma vegetação secundária que sucede à derrubada da floresta. Essa vegetação é constituída, em especial, por indivíduos lenhosos de segundo crescimento. Sua composição florestal apresenta, em sua maioria, espécies da floresta anterior e espécies espontâneas, que invadem as áreas devastadas. Assim, os estratos da capoeira variam do porte arbustivo até o arbóreo com árvores finas e compactamente dispostas.

Ao seguir os critérios de classificação propostos por Romariz, as capoeiras enquadram-se nas matas do tipo 8. Esse tipo de mata possui uma ampla variação fisionômica. No geral, as árvores de maior porte ocorrem em número menor e o distanciamento das copas é maior, o que forma uma cobertura florestal entre $40 \%$ e $50 \%$. As árvores possuem, normalmente, diâmetro inferior a $30 \mathrm{~cm}$, casca lisa, muito ramificada e com altura que pode atingir de oito a $10 \mathrm{~m}$. A maior incidência de luz no estrato arbustivo resulta em seu maior desenvolvimento, diferente do que acontece nas matas do tipo 2 . Quando apresentarem um estrato arbóreo bem desenvolvido, as matas do tipo 8 podem ser denominadas como capoeirão, sendo um estágio muito próximo de uma floresta primária.

\subsubsection{Campo Sujo}

$\mathrm{Na}$ classificação proposta por Romariz, definiu-se essa vegetação como do tipo C, caracterizado pela predominância de arbustos e subarbustos, sem a presença de árvores altas, apenas algumas muito baixas que variam no máximo de seis a sete metros. O diâmetro médio das espécies é de $10 \mathrm{~cm}$, com troncos lisos e claros. No geral, a altura média dessa classe de cobertura vegetal varia entre cinco e seis metros. Considerada uma transição entre campo e capoeira, o aspecto fisionômico dessa categoria aproxima-se mais da categoria capoeira do que campo. 


\subsubsection{Campo}

Esse tipo de vegetação possui como característica uma cobertura vegetal graminóide e herbácea, sem a presença de árvores. Assim, a categoria campo possui apenas o estrato herbáceo.

\subsubsection{Reflorestamento}

Segundo o Levantamento da Cobertura Vegetal Natural e do Reflorestamento no Estado de São Paulo, os reflorestamentos são formações disciplinadas e homogêneas quanto às essências, plantadas em forma de maciços para o suprimento industrial e em talhões isolados, geralmente para o consumo interno dos estabelecimentos rurais. Normalmente, os reflorestamentos apresentam limites regulares e carreadores (caminhos) definidos.

\subsubsection{Avaliação da situação da cobertura vegetal e do uso e ocupação do solo na ANT da Serra do Boturuna e zona de amortecimento em 1986}

A Tabela 7 e o Mapa 4 apresentam a distribuição do uso e ocupação do solo e cobertura vegetal na ANT da Serra do Boturuna e no perímetro de 300m, em 1986. Com relação à Tabela 7, optou-se também por representar a distribuição dessas classes conforme os municípios. Destaca-se que Araçariguama possui pequenos compartimentos na faixa de $300 \mathrm{~m}$ que equivalem a, apenas, 1,40\% da área total do mapeamento. Nesse sentido, as áreas da ANT e seu perímetro de 300m incluem-se, em quase sua totalidade, nos municípios de Pirapora do Bom Jesus e de Santana de Parnaíba.

Apesar do período de análise ser um pouco posterior ao ato de tombamento, é possível demonstrar, por meio das informações, a situação do recobrimento vegetal na Serra do Boturuna a partir de sua constituição como um espaço natural protegido. 
Tabela 7 - Uso e ocupação do solo e cobertura vegetal (1986) na ANT da Serra do Boturuna e zona de amortecimento

\begin{tabular}{|c|c|c|c|c|}
\hline \multirow{4}{*}{$\begin{array}{l}\text { Categorias de Uso e } \\
\text { Ocupação do Solo }\end{array}$} & \multirow{3}{*}{$\begin{array}{l}\text { ANT da Serra do } \\
\text { Boturuna }(300 \mathrm{~m})\end{array}$} & Araçariguama & $\begin{array}{l}\text { Pirapora do } \\
\text { Bom Jesus }\end{array}$ & $\begin{array}{c}\text { Santana de } \\
\text { Parnaíba }\end{array}$ \\
\hline & & $\begin{array}{c}\text { \% de Área na } \\
\text { ANT }\end{array}$ & $\begin{array}{c}\text { \% de Área na } \\
\text { ANT }\end{array}$ & $\begin{array}{c}\text { \% de Área na } \\
\text { ANT }\end{array}$ \\
\hline & & $1,40 \%$ & $49,16 \%$ & $49,43 \%$ \\
\hline & \% de Área & \% de Área & \% de Área & \% de Área \\
\hline Campo & $40,66 \%$ & $0,05 \%$ & $76,12 \%$ & $23,84 \%$ \\
\hline Campo Sujo & $11,69 \%$ & $0,00 \%$ & $48,07 \%$ & $51,93 \%$ \\
\hline Capoeira & $21,67 \%$ & $6,35 \%$ & $17,38 \%$ & $76,28 \%$ \\
\hline Hortifrutigranjeiro & $0,20 \%$ & $0,00 \%$ & $36,63 \%$ & $63,37 \%$ \\
\hline $\begin{array}{l}\text { Loteamento } \\
\text { Desocupado }\end{array}$ & $1,58 \%$ & $0,00 \%$ & $73,84 \%$ & $26,16 \%$ \\
\hline Mata & $15,74 \%$ & $0,00 \%$ & $13,33 \%$ & $86,67 \%$ \\
\hline Mineração Abandonada & $0,82 \%$ & $0,00 \%$ & $100,00 \%$ & $0,00 \%$ \\
\hline Mineração Em Atividade & $3,05 \%$ & $0,00 \%$ & $94,17 \%$ & $5,83 \%$ \\
\hline $\begin{array}{l}\text { Movimento de } \\
\text { Terra/Solo Exposto }\end{array}$ & $0,04 \%$ & $0,00 \%$ & $0,00 \%$ & $100,00 \%$ \\
\hline Reflorestamento & $4,55 \%$ & $0,16 \%$ & $39,58 \%$ & $60,26 \%$ \\
\hline & Composição da & Categoria Capo & & \\
\hline $\begin{array}{c}\text { Campo Sujo e } \\
\text { Capoeira }\end{array}$ & $33,36 \%$ & $4,12 \%$ & $28,13 \%$ & $67,75 \%$ \\
\hline
\end{tabular}

A área total da ANT e o perímetro de $300 \mathrm{~m}$ compunham-se de, aproximadamente, $41 \%$ por campos degradados, concentrados em Pirapora do Bom Jesus $(76,12 \%)$ As áreas de matas distribuíam-se em apenas $15 \%$ do espaço protegido. Entretanto, a vegetação florestal também estava distribuída de forma desigual conforme o município, assim, por volta de $87 \%$ das matas se concentrava, em Santana de Parnaíba.

O mapeamento distinguiu a cobertura vegetal composta por campos sujos e capoeiras. Convém destacar que dessas duas categorias apresentamse como um continuum, assim, pode-se considerar o campo sujo um estágio inicial de capoeira. É importante destacar que no topo da Serra do Boturuna, a vegetação predominante se constituía de campo cerrado ou campo de altitude. A Tabela 7 também descreve as duas tipologias e uma composição que inclui as porcentagens conjuntas. A análise do conjunto que inclui o campo sujo e a capoeira demonstrou que essa fisionomia vegetacional se constituía no segundo recobrimento mais presente na ANT e no perímetro de $300 \mathrm{~m}$. Todavia, Santana de Parnaíba representava, aproximadamente, de $68 \%$ da 
dessa cobertura no mapeamento. As áreas do perímetro de $300 \mathrm{~m}$ que se inserem em Araçariguama apresentavam, em sua maioria, o recobrimento vegetal composto por capoeiras.

As áreas de reflorestamento também encontravam as maiores representatividades em Santana de Parnaíba. No conjunto da ANT, essa cobertura apresentava-se em, aproximadamente, $5 \%$ do espaço protegido, por volta de $60 \%$ dos reflorestamentos estavam em Santana de Parnaíba.

A extensão das áreas de mineração contribuía em cerca de $5 \%$ da área protegida. As minerações abandonadas e em atividade localizavam-se de forma predominante em Pirapora do Bom Jesus. Destaca-se uma mineração em Pirapora do Bom Jesus que suas frentes de lavras avançaram em Santana de Parnaíba. Esse fato fez com que o município participasse por volta de $6 \%$ das áreas de mineração.

Por meio desses dados é possível traçar o perfil do uso e ocupação do solo na ANT e no perímetro de 300m conforme o município. Dessa forma, a ANT em Pirapora do Bom Jesus constituía-se por campos degradados (63\%) e minerações abandonadas ou em atividades (8\%).

Em Santana de Parnaíba, a ANT da Serra do Boturuna justificava a importância do ato de tombamento. Além de três grandes compartimentos composto por matas (28\%), que incluíam parte das encostas e as menores altitudes da Serra, havia diversas áreas com cobertura secundária composta por campo sujo e capoeira (45\%), o que, em determinadas áreas, pressupunha um estágio de sucessão de vegetação. A vegetação de campo concentrava-se nesse município nas maiores altitudes da Serra do Boturuna. 


\subsection{EM 2002}

O mapa de uso e ocupação do solo de 2002 para a ANT da Serra do Boturuna e perímetro de $300 \mathrm{~m}$ partiu da interpretação, em tela, de composições coloridas de imagens de alta resolução do satélite lkonos. O apoio fundamental desse mapeamento foi o mapa de uso e ocupação do solo da Região Metropolitana de São Paulo e Bacia do Alto Tietê, também elaborado com essas imagens pela EMPLASA. Entretanto, procurou-se detalhar a interpretação ao analisar as áreas com indícios de antiga atividade de exploração mineral e a delimitação de todos os compartimentos das categorias capoeira e mata.

De forma geral, utilizou-se a mesma base conceitual das categorias de uso e ocupação do solo do mapeamento realizado pela EMPLASA. Contudo, as categorias de cobertura vegetal, interpretadas como mata e campo, passaram por algumas generalizações, o que tornou a interpretação dessas tipologias de recobrimento mais abrangente.

A caracterização das matas ocorreu com base no conceito da UNESCO (1973). O conceito considera que tal fisionomia vegetal é composta por árvores com porte superior a cinco metros ou menos de cinco metros em formações que propiciem uma cobertura de $40 \%$. Ao seguir esse pressuposto, as coberturas florestais menores que $40 \%$ e entre 40 e $50 \%$, que possuem árvores de menor porte, incluem-se na categoria capoeira. Com isso, atribui-se a essa categoria o porte arbustivo alto e o porte florestal baixo. Uma importante modificação com relação ao mapeamento de 1986, consistiu-se na inclusão da categoria campo sujo como capoeira. Assim, a caracterização das categorias de uso e ocupação do solo partiu dos seguintes conceitos:

\subsubsection{Mata}

Baseou-se no conceito da UNESCO (1973) que considera as áreas que possuem cobertura florestal maior que $40 \%$. Nesta categoria, incluem-se os capoeirões. 


\subsubsection{Capoeira}

Considerou-se a transição entre campo e mata. A capoeira possui cobertura florestal, portanto, as árvores apresentam menor porte. Incluiu-se também, nesta categoria, o campo sujo.

\subsubsection{Campo}

O campo possui gramíneas com altura que varia entre 10 e $15 \mathrm{~cm}$, subarbustos e, raramente, arbustos distanciados um do outro. A cobertura pode ser contínua ou com trechos de solo descoberto.

\subsubsection{Reflorestamento}

Caracterizados por formações arbóreas e homogêneas, cultivadas com fim econômico, por exemplo, espécies do gênero eucalyptus ou do gênero pinus.

\subsubsection{Hortifrutigranjeiro}

Correspondem às culturas de ciclo longo: árvores ou arbusto de espécies frutíferas, arroz, trigo, milho, entre outras; horticulturas representadas por hortaliças e flores; e, granjas caracterizadas por suas instalações de avicultura e produção de ovos.

\subsubsection{Movimento de terra/solo exposto}

Identificadas pelas seguintes características: áreas de soloplanagem; solo exposto preparado para o plantio; áreas com ausência de cobertura vegetal; e as áreas com o estabelecimento de processos erosivos. 


\subsubsection{Mineração em atividade e abandonada}

Caracterizaram-se as minerações em atividade conforme a situação no Departamento Nacional de Produção Mineral (DNPM). Assim, se a área identificada na imagem como mineração, não havia poligonal ativa registrada nesse órgão, optou-se por considerá-la como mineração abandonada. Deve-se também destacar que a área de mineração abandonada pode se referir às explorações clandestinas.

\subsection{8 Área Urbanizada}

Constituem-se de áreas com arruamento, ocupadas por uso residencial, comercial ou serviços.

\subsubsection{Chácara}

Correspondem aos loteamentos de chácaras de lazer ou residencial, identificadas por meio das suas sedes, dos pomares, das hortas, do solo preparado para o plantio, dos lagos, dos bosques, das quadras, das piscinas, entre outros (pomares e hortas enquadram-se nesta categoria quando possuem a função de subsistência).

\subsubsection{Lagoa}

Determinadas pelos corpos d'água que resultam do represamento de córrego ou ribeirões. 


\subsubsection{Avaliação das mudanças na cobertura vegetal e no uso e ocupação do solo na ANT da Serra do Boturuna e zona de amortecimento}

A Tabela 8 e o Mapa 5 representam o contexto do uso e ocupação do solo na ANT da Serra do Boturuna e do perímetro de $300 \mathrm{~m}$, em 2002. Por meio desses dados, é possível aferir qual o resultado prático do ato de tombamento, em relação à proteção da cobertura vegetal da Serra do Boturuna após, aproximadamente, 20 anos da institucionalização da ANT.

A cobertura vegetal nesse espaço protegido ainda se compõe, predominantemente, por campos. Apesar de muitas dessas áreas constituírem o aspecto primitivo da vegetação na ANT (topo da Serra), tal recobrimento vegetal, sobretudo, na área da ANT em Pirapora do Bom Jesus, decorre na retirada da cobertura florestal para o estabelecimento de pastagens ou de minerações.

A análise do Mapa 5, juntamente com os dados da Tabela 8, demonstra que a maior representatividade das reservas de matas se mantém em Santana de Parnaíba (80,38\%). Entretanto, verifica-se que o percentual de participação desse recobrimento na ANT referente à Pirapora do Bom Jesus aumentou de $15,75 \%$ para $17,80 \%$. Atribui-se o aumento da cobertura de mata na ANT, em Pirapora do Bom Jesus, em grande parte, pela recomposição das matas ciliares. No contexto geral da ANT, a cobertura de mata, em 2002, correspondeu a, aproximadamente, 32\%. O Gráfico 1 comprova que a área desse recobrimento dobrou em relação a 1986. Ao analisar os dados da cobertura de mata no contexto dos municípios, os Gráficos 1, 2 e 3 demonstraram o aumento dessa cobertura para todos os municípios. 
Tabela 8 - Uso e ocupação do solo e cobertura vegetal (2002) na ANT da Serra do Boturuna e zona de amortecimento

\begin{tabular}{|c|c|c|c|c|}
\hline \multirow{4}{*}{$\begin{array}{c}\text { Categorias de Uso } \\
\text { e Ocupação do } \\
\text { Solo }\end{array}$} & \multirow{3}{*}{$\begin{array}{l}\text { ANT da Serra do } \\
\text { Boturuna }(300 \mathrm{~m})\end{array}$} & Araçariguama & $\begin{array}{l}\text { Pirapora do } \\
\text { Bom Jesus }\end{array}$ & $\begin{array}{c}\text { Santana de } \\
\text { Parnaíba }\end{array}$ \\
\hline & & $\begin{array}{c}\text { \% de Área na } \\
\text { ANT }\end{array}$ & $\begin{array}{c}\text { \% de Área na } \\
\text { ANT }\end{array}$ & $\begin{array}{c}\text { \% de Área } \\
\text { na ANT }\end{array}$ \\
\hline & & $1,40 \%$ & $49,16 \%$ & $49,43 \%$ \\
\hline & \% de Área & \% de Área & \% de Área & \% de Área \\
\hline Área Urbanizada & $0,23 \%$ & $0,00 \%$ & $100,00 \%$ & $0,00 \%$ \\
\hline Campo & $41,08 \%$ & $0,51 \%$ & $68,83 \%$ & $30,66 \%$ \\
\hline Capoeira & $13,66 \%$ & $2,31 \%$ & $40,55 \%$ & $57,14 \%$ \\
\hline Chácara & $1,37 \%$ & $0,00 \%$ & $56,63 \%$ & $43,37 \%$ \\
\hline Hortifrutigranjeiro & $0,01 \%$ & $0,00 \%$ & $0,00 \%$ & $100,00 \%$ \\
\hline Lagoa & $0,12 \%$ & $0,00 \%$ & $78,49 \%$ & $21,51 \%$ \\
\hline Mata & $31,57 \%$ & $1,82 \%$ & $17,80 \%$ & $80,38 \%$ \\
\hline $\begin{array}{c}\text { Mineração } \\
\text { Abandonada }\end{array}$ & $0,11 \%$ & $0,00 \%$ & $100,00 \%$ & $0,00 \%$ \\
\hline $\begin{array}{l}\text { Mineração Em } \\
\text { Atividade }\end{array}$ & $5,75 \%$ & $0,00 \%$ & $95,09 \%$ & $4,91 \%$ \\
\hline $\begin{array}{c}\text { Movimento de } \\
\text { Terra/Solo Exposto }\end{array}$ & $1,37 \%$ & $0,00 \%$ & $100,00 \%$ & $0,00 \%$ \\
\hline Reflorestamento & $4,73 \%$ & $6,40 \%$ & $35,54 \%$ & $58,06 \%$ \\
\hline
\end{tabular}

Gráfico 1 - Distribuição quantitativa das classes de uso e ocupação do solo na ANT da Serra do Boturuna (1986 a 2002)

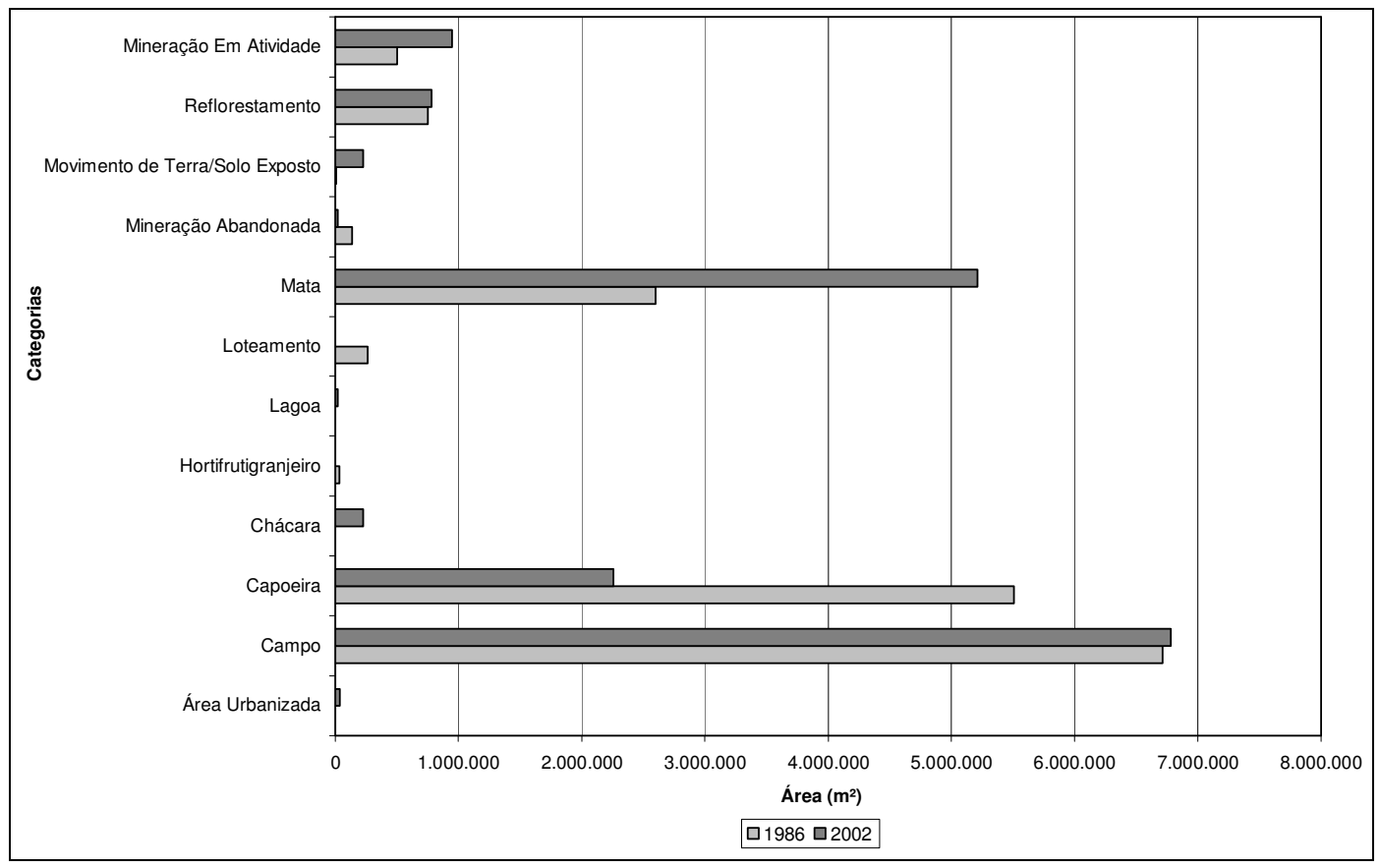

O aumento do recobrimento vegetal por matas atrela-se à diminuição das áreas com capoeiras. A participação dessa cobertura na ANT passou de 33,36\% (capoeira e campo sujo), em 1986, para 13,66\%, em 2002. 
Possivelmente, tais informações demonstrem a sucessão vegetacional que as áreas de capoeira apresentaram. Santana de Parnaíba possui a maior participação das áreas de capoeiras na ANT com 57,14\%.

No período de análise, o recobrimento vegetal por campos manteve-se estável em, aproximadamente, $41 \%$. Porém, constatou-se o aumento da participação dessa cobertura por Santana de Parnaíba, que oscilou de $23,84 \%$, 1986, para 30,66\%, em 2002. O Gráfico 5, que apresenta o contexto municipal do uso e da ocupação do solo na ANT, confirma o aumento da cobertura por campo na área natural tombada no município. Convém destacar que o maior detalhe do mapeamento de 2002 e a dificuldade na classificação do campo sujo contribuem para a diminuição da precisão desses dados.

Gráfico 2 - Distribuição quantitativa das classes de uso e ocupação do solo na ANT da Serra do Boturuna, em Pirapora do Bom Jesus - SP (1986 a 2002)

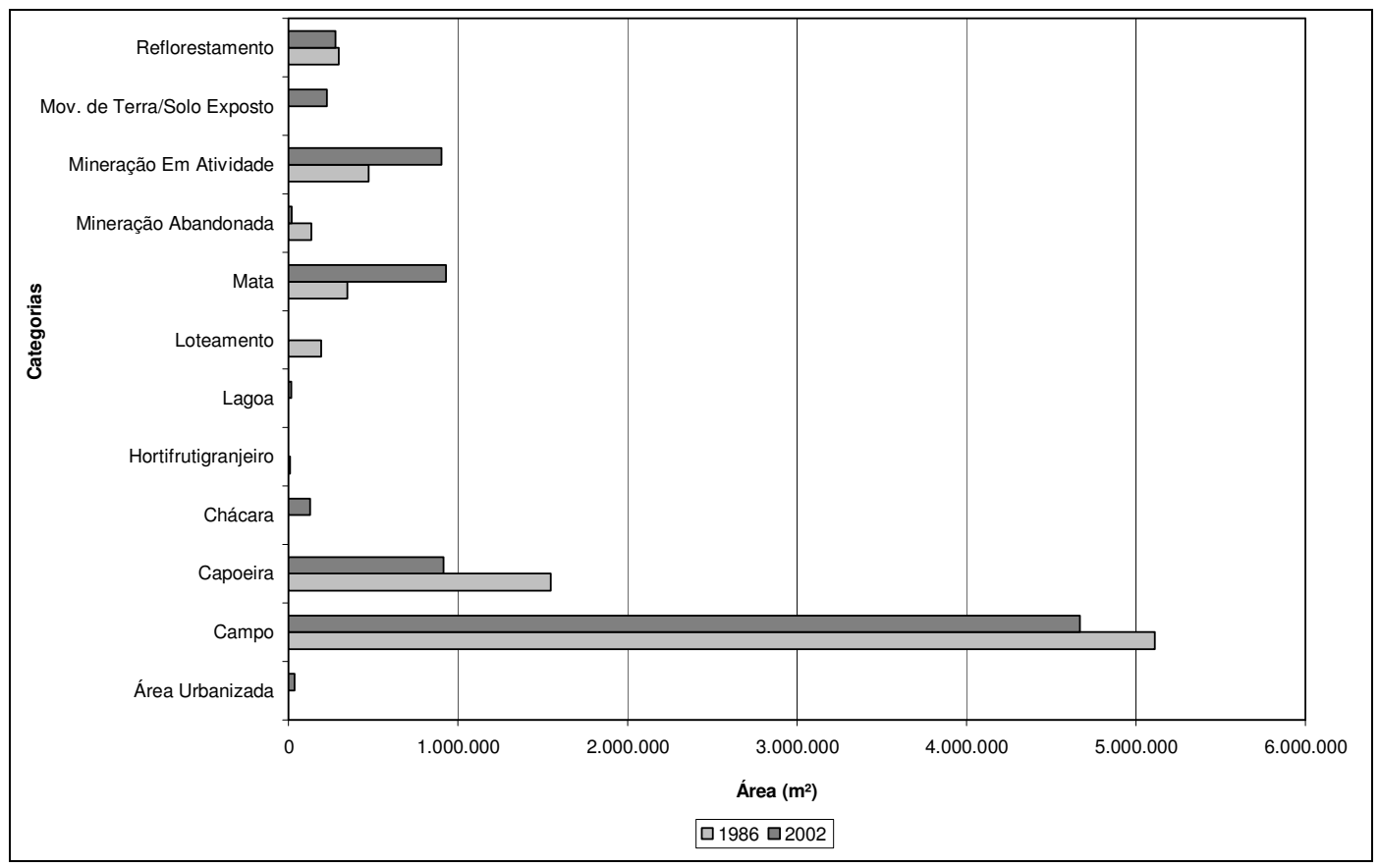




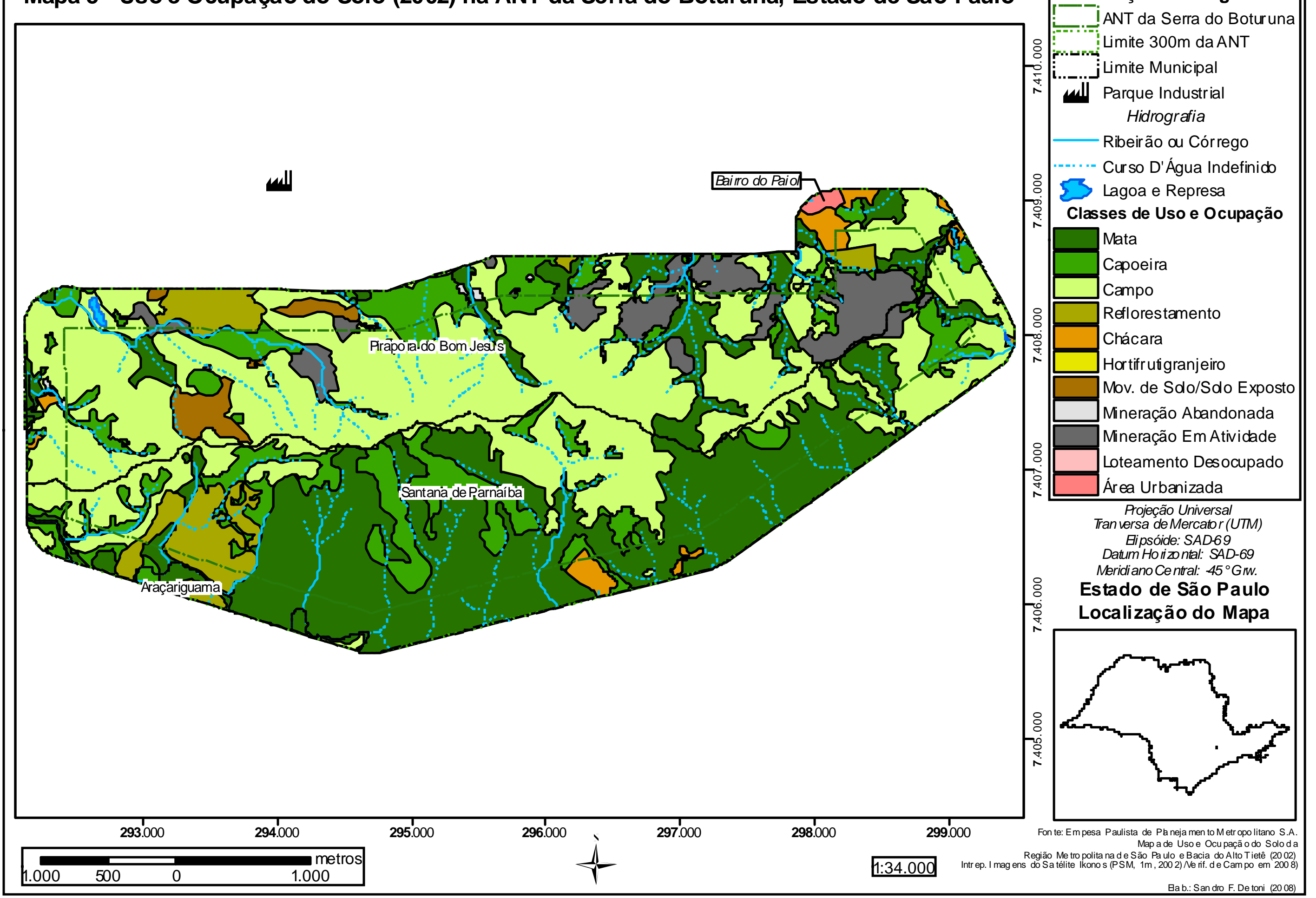


Gráfico 3 - Distribuição quantitativa das classes de uso e ocupação do solo na ANT da Serra do Boturuna, em Santana de Parnaíba - SP (1986 a 2002)

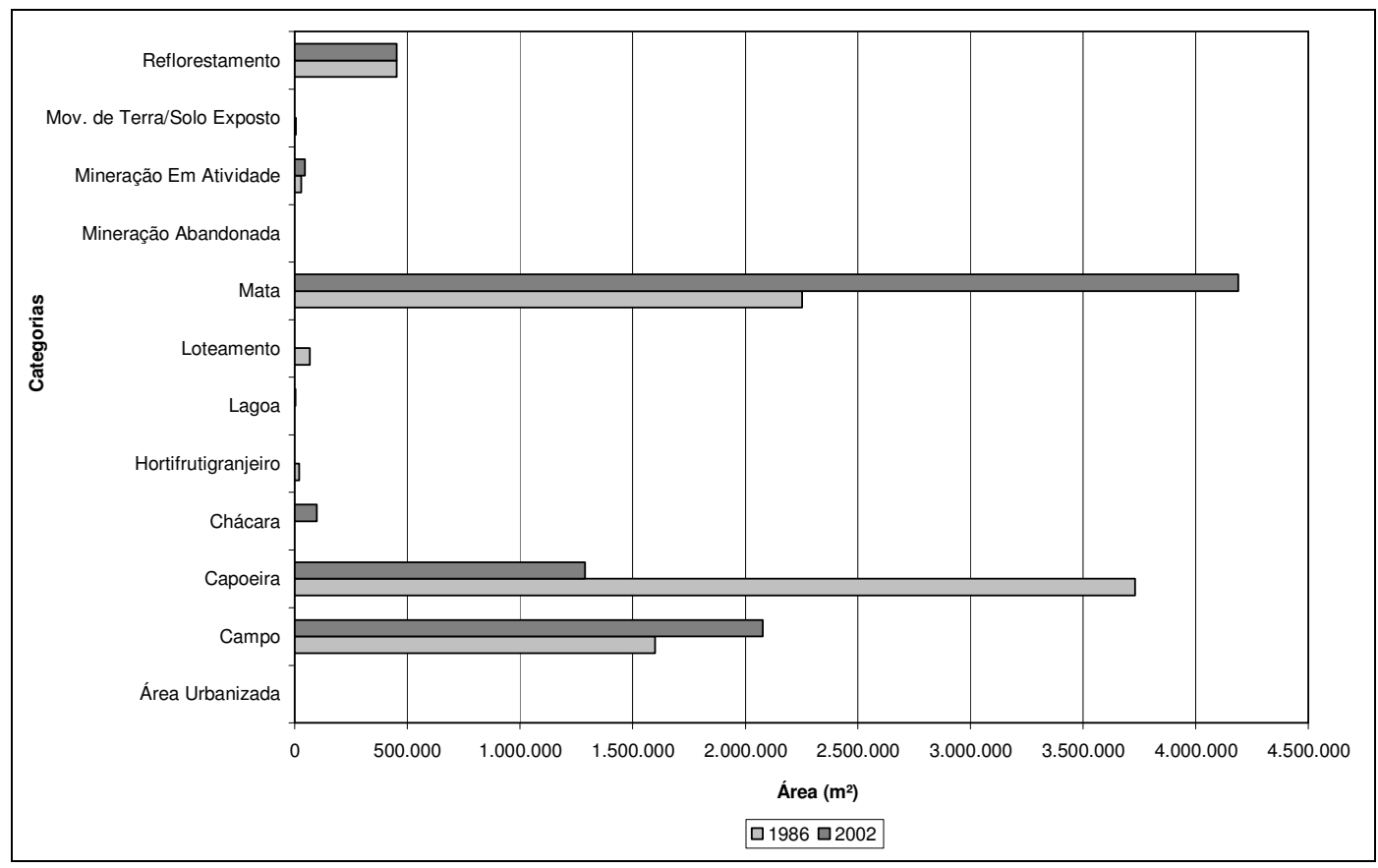

As áreas de reflorestamento também se mantiveram estáveis no período de análise. O percentual de recobrimento dessas áreas se conservou em torno de $4,5 \%$ da ANT. O Gráfico 4 demonstra um aumento significativo dessa cobertura em Araçariguama. Contudo, como a participação desse município na ANT corresponde somente a pequenas porções na zona de amortecimento de $300 \mathrm{~m}$, tal aumento possui reflexo insignificante no contexto geral da ANT.

Com relação à atividade de mineração, o recobrimento espacial das lavras aumentou no período, a somatória das áreas em atividade e das áreas abandonadas, corresponde a, aproximadamente, $6 \%$ da área total da ANT. Convém destacar que, em virtude das características locais, sobretudo pelo estabelecimento de processos erosivos, caracterizaram-se duas áreas de mineração abandonadas como movimento de terra/solo exposto. Ressaltar-se também que, apesar do processo de cessão de direitos minerários, incluiu-se a lavra da Quartzolit como mineração em atividade. 
Gráfico 4 - Distribuição quantitativa das classes de uso e ocupação do solo na ANT da Serra do Boturuna, em Araçariguama - SP (1986 a 2002)

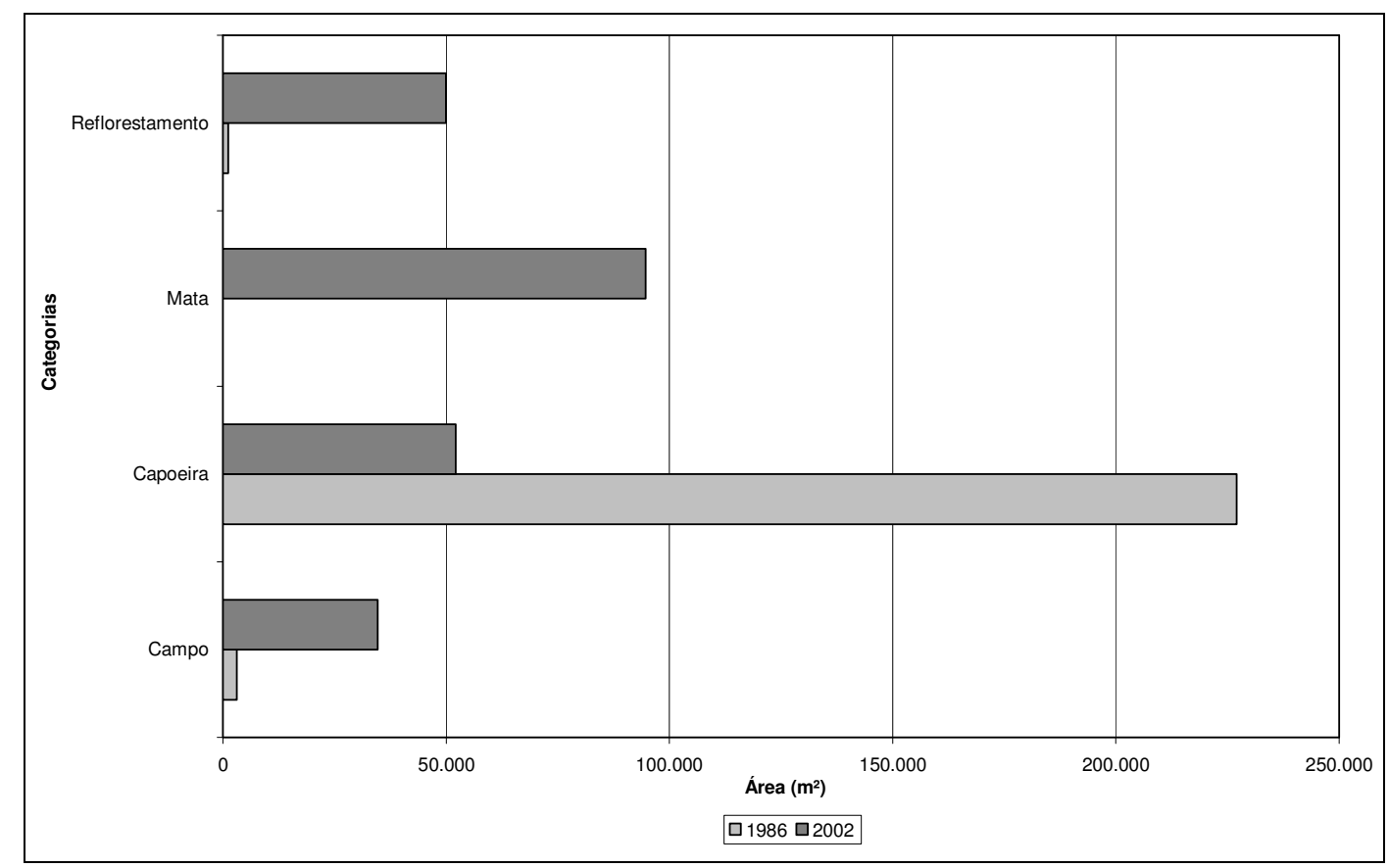

A participação de Pirapora do Bom Jesus na composição total das áreas de lavra de mineração na ANT é majoritária. Dessa forma, o quadro da representatividade da distribuição dessa cobertura entre os municípios apresentou-se pouco alterado.

Devido à boa resolução espacial das imagens do satélite Ikonos, foi possível identificar antigas áreas de mineração na ANT e que, em 2002, possuíam algum tipo de cobertura vegetal (campo ou capoeira) ou onde se estabeleceram processos erosivos, sendo mapeadas como movimento de terra/solo exposto. Tais áreas correspondem a aproximadamente $2 \%$ da ANT e do perímetro de $300 \mathrm{~m}$. Porém, ao considerar somente a abrangência da ANT em Pirapora do Bom Jesus, as antigas áreas de mineração correspondiam a, aproximadamente, $4 \%$ da área de tombamento no município. A Tabela 9 representa o percentual espacial das antigas frentes de lavra nas categorias capoeira, campo e movimento de terra/solo exposto. Nas áreas mapeadas como movimento de terra/solo exposto, por volta de 95\%, constituía-se de antigas frentes de lavra abandonadas. 
Essas áreas não passaram por processos de recuperação, sendo abandonadas. Logo, o estabelecimento da cobertura vegetal foi espontâneo. As áreas de movimento de terra/solo exposto localizam-se, muitas vezes, em setores da Serra do Boturuna com embasamento quartzítico, onde não foi possível a colonização espontânea por espécies vegetais, em virtude das características pedológicas ou com estabelecimento de fortes processos erosivos.

Tabela 9 - Distribuição quantitativa das antigas frentes de lavras identificadas por categorias de uso e ocupação do solo (2002) na ANT da Serra do Boturuna.

\begin{tabular}{|c|c|}
\hline Categorias de Uso e Ocupação do Solo & \% das Antigas Frentes de Lavra \\
\hline Capoeira & $1,67 \%$ \\
\hline Campo & $1,09 \%$ \\
\hline Movimento de Terra/Solo Exposto & $95,07 \%$ \\
\hline
\end{tabular}

Outra importante questão que se coloca é o estabelecimento de uma área urbanizada nos limites da ANT e no perímetro de $300 \mathrm{~m}$. O mapeamento de 2002 demonstra a consolidação como área urbanizada do loteamento Paiol, em Pirapora do Bom Jesus. No Mapa 5, é possível verificar o loteamento, localizado a nordeste da ANT, juntamente com o avanço desse núcleo urbana para os limites da área tombada.

Os dados demonstram que as maiores extensões de coberturas florestais preservadas encontram-se, sobretudo, nas vertentes da Serra do Boturuna orientadas para o sul. Dessa forma, como o processo da retirada da cobertura vegetal original foi mais intenso nas vertentes orientadas para 0 norte, a ANT no município de Pirapora do Bom Jesus apresenta-se, consideravelmente, degradada em relação ao recobrimento vegetal e com o predomínio de campos degradados, compostos de vegetação herbácea e alguns núcleos de vegetação arbustiva.

Sugere-se que a proximidade da Serra do Boturuna com o núcleo urbano de Pirapora do Bom Jesus e a base econômica do município incluemse como fatores determinantes para que o desmatamento fosse maior nas vertentes da Serra nesse município.

A Serra do Boturuna é um elemento marcante na paisagem de Pirapora do Bom Jesus. Num primeiro momento, a retirada da cobertura vegetal natural 
atrelava-se à atividade agropecuária desorientada, caracterizada pelo emprego de práticas rudimentares como a limpeza dos pastos por meio de queimadas anuais. Realizam tal prática também com o intuito de evitar o estabelecimento de vegetação secundária. Outro fator que contribuiu para o desmatamento relaciona-se à atuação da atividade de extração mineral, que incluiu também a extração clandestina.

Conforme se mencionou, o Plano Diretor municipal apresentava como proposta para a Serra do Boturuna, a criação da APA Pirapora Sul. No entanto, em levantamento realizado junto a Secretaria de Obras desse município, verificou-se nenhum procedimento para concretizar a diretriz ambiental sugerida.

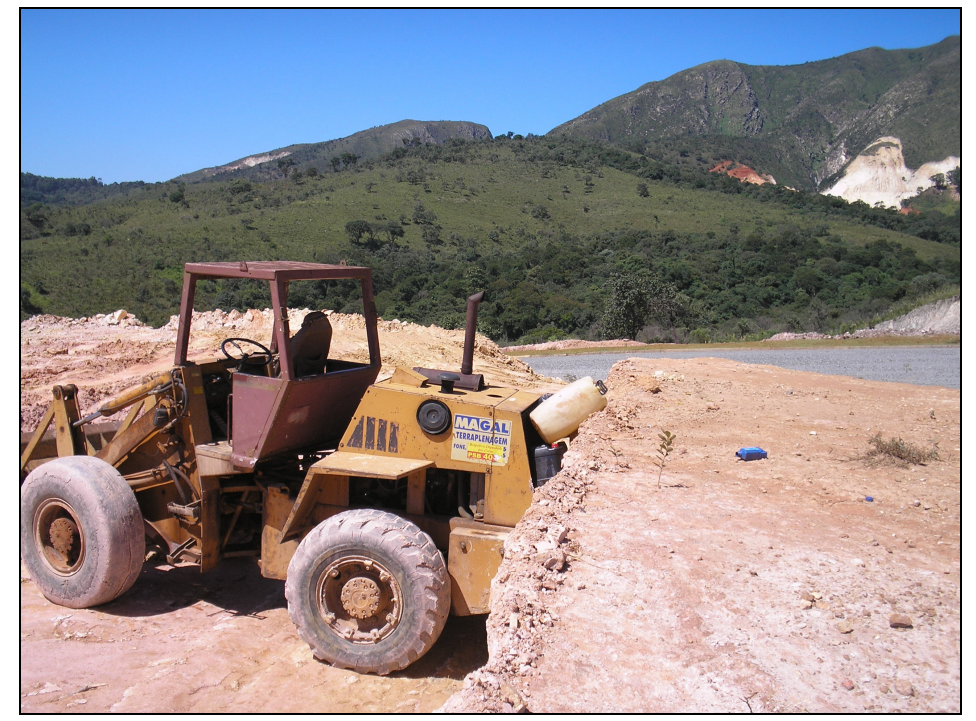

Figura 6 - Área do parque industrial: à direita, em segundo plano, a Serra do Boturuna e o componente marcante na paisagem, a mineração (Sandro F. Detoni, abril de 2008)

Apesar da localização fora dos limites do tombamento e do perímetro de $300 \mathrm{~m}$, deve-se considerar na análise do uso e ocupação do solo, o projeto do Parque Industrial de Pirapora do Bom Jesus. A área desse Parque Industrial fica a, aproximadamente, um quilômetro do perímetro de tombamento da Serra. Dessa forma, esse empreendimento causará um sensível impacto na paisagem regional. 
De acordo com informações junto à Secretaria de Desenvolvimento Urbano $^{21}$, o terreno, cedido a um grupo de empresários da indústria plástica, decorre de uma desapropriação efetuada pela prefeitura.

$\mathrm{Na}$ área, efetuaram-se somente as obras de terraplanagem e asfaltamento das ruas. Todavia, segundo o contrato de cessão do terreno, a instalação das indústrias deve ocorrer até o início de 2009, caso contrário, o grupo de empresários perderá o direito sobre a área. Na visita a região, realizada em junho de 2008, ainda não havia sido realizada a construção dos galpões industriais. Apesar da aprovação das licenças ambientais junto à Companhia de Tecnologia de Saneamento Ambiental do Estado de São Paulo (CETESB), denota-se que as obras antecederam a lei, pois a área não possui a regulamentação de Zona de Uso Predominante Industrial (ZUPI) aprovada pela Assembléia Legislativa do Estado de São Paulo. Esse procedimento possui seus dispositivos legais na Lei Estadual n. 1.817/1978.

O impacto sobre a paisagem regional é muito forte. O local é uns dos mirantes mais belos de Pirapora. Além da visão da Serra do Boturuna, é possível contemplar o rio Tietê. $\mathrm{O}$ impacto na paisagem, possivelmente, pode ocorrer de forma conjunta ao impacto urbano no município, pois um parque industrial atrai trabalhadores e ocupação urbana. Convém destacar que Pirapora do Bom Jesus possui poucas áreas favoráveis a essa expansão.

Em Santana de Parnaíba, a Serra do Boturuna, aparentemente, não adquiriu muita importância econômica, há somente algumas áreas de silvicultura, chácaras e condomínios residenciais. Provavelmente, esse fato, possa se relacionar à expansão do núcleo urbano dessa cidade. No geral, o crescimento urbano desse município orientou-se para o limite com o município de Barueri, local onde está localizado o condomínio Alphaville. Assim, na região da Serra do Boturuna, a cobertura vegetal se encontra preservada ou em estágio de recuperação.

\footnotetext{
${ }^{21}$ Informação pessoal do coordenador de meio ambiente Ailton Paulo Pinto
} 


\section{CARACTERIZAÇÃO GEOLÓGICA}

\subsection{CONTEXTO GEOLÓGICO REGIONAL}

A caracterização geológica da região da Serra do Boturuna envolve dois aspectos fundamentais: a análise de seu potencial mineralógico e a ênfase sobre o atributo que destaca a Serra na paisagem regional, ou seja, o embasamento litológico. Esses aspectos se configuram como os principais conflitos de interesses existentes atualmente nessa ANT.

A presença de uma atividade mineradora determina-se em virtude das condições de aproveitamento econômico de um determinado tipo de rocha ou mineral Conforme se mencionou, o embasamento litológico da Serra condicionou sua formação geomorfológica diferenciada no Planalto Atlântico. $O$ aspecto topográfico contribuiu como um dos principais atributos para 0 tombamento da Serra junto ao CONDEPHAAT. Contudo, as características litoestruturais da região, sobretudo da Serra do Boturuna, também permitiram o amplo desenvolvimento da atividade mineradora, em especial, para a exploração do quartzito, dos calcários e do filito. Destaca-se que a Serra do Boturuna já foi um dos principais pólos, na RMSP, de exploração de algumas dessas substâncias minerais. Nesse contexto, com o intuito de verificar o panorama geológico que envolve a Serra, partiu-se da análise regional dessa temática com destaque para os municípios de Pirapora do Bom Jesus e de Santana de Parnaíba.

Além da bibliográfica básica, que envolveu os diversos aspectos geológicos da região, elaborou-se um mapa geológico digital de Pirapora do Bom Jesus e de Santana de Parnaíba por meio do mapeamento básico da EMPLASA. Para isso, utilizaram-se as folhas geológicas 1: 50.000 descritas no Quadro 2.

Quadro 2 - Folhas geológicas utilizadas na elaboração do mapa geológico

\begin{tabular}{|c|c|}
\hline Folhas & Índice de Nomenclatura \\
\hline Cabreúva (14) & SF.23-Y-C-II-4 \\
\hline Osasco (23) & SF.23-Y-C-IV-1 \\
\hline Santana de Parnaíba (24) & SF.23-Y-C-III-3 \\
\hline
\end{tabular}


Com relação à estrutura litológica, em Pirapora do Bom Jesus e em Santana de Parnaíba predominam as litologias do Pré-Cambriano, caracterizado por rochas antigas submetidas a distintos ciclos de dobramentos, que permitiu a denominação como Região de Dobramentos do Sudeste.

Essa região possui distintas faixas de dobramentos que foram setorizadas por meio da identificação dos sistemas de falhas existentes. Dessa forma, os municípios em questão estão sobre a Faixa de Dobramento do Ribeira que, por sua vez, subdivide-se nos Sistemas de Dobramentos de Apiaí e de São Roque, delimitados pela Falha transcorrente, ou Zona de Cisalhamento de Taxaquara. Nesse sentido, Pirapora do Bom Jesus e Santana de Parnaíba estão sobre o Sistema de Dobramento de São Roque, mais especificamente, encontram-se no Bloco São Roque (ALMEIDA, 1976).

As delimitações do Bloco São Roque decorrem de um sistema de falhas transcorrentes com as seguintes denominações: ao norte localiza-se a falha de Jundiuvira, ao sul a falha de Taxaquara e a leste e a oeste localizam-se, respectivamente, as falhas de Mairinque e de Mandaqui. Destaca-se que a Serra do Boturuna localiza-se no setor Juqueri do Bloco São Roque (HASUI et al. 1969 apud IPT, 1984).

A partir dessas informações, observa-se que a morfogênese da região relaciona-se, sobretudo, ao estabelecimento de uma compartimentação estrutural em blocos e ao sistema de falhas transcorrentes.

A evolução geológica associa-se, num primeiro momento, à sedimentação geossinclinal por meio da deposição de seqüências sedimentares dos Grupos São Roque e Açungui, no Pré-Cambriano Superior. (HASUI, 1975b). A intensa atividade tectônica posterior favoreceu a formação de metassedimentos pelíticos e pesamíticos, alguns metaconglomerados e dolomitos (HASUI; SOARES; CSORDAS, 1978).

A consolidação da Plataforma Sul-americana resulta dos processos geosinclinal e tecto-orogenético que se iniciaram c.a. $1.000 \mathrm{Ma}$ e cessaram-se entre o final do Pré-Cambriano e o CambroOrdoviciano, incluídos o Ciclo Brasiliano. - tradução nossa ${ }^{22}$ (ALMEIDA, 1967 apud ALMEIDA, HASUI, NEVES, 1976, p. 47)

\footnotetext{
${ }^{22}$ The South American Platform consolidated as a result of the geosynclinal and tecto-orogenic processes which began ca. 1000 m.y. and ceased between the end of the Precambrian and the Cambro-Ordovician, included in Brasiliano Cycle
} 


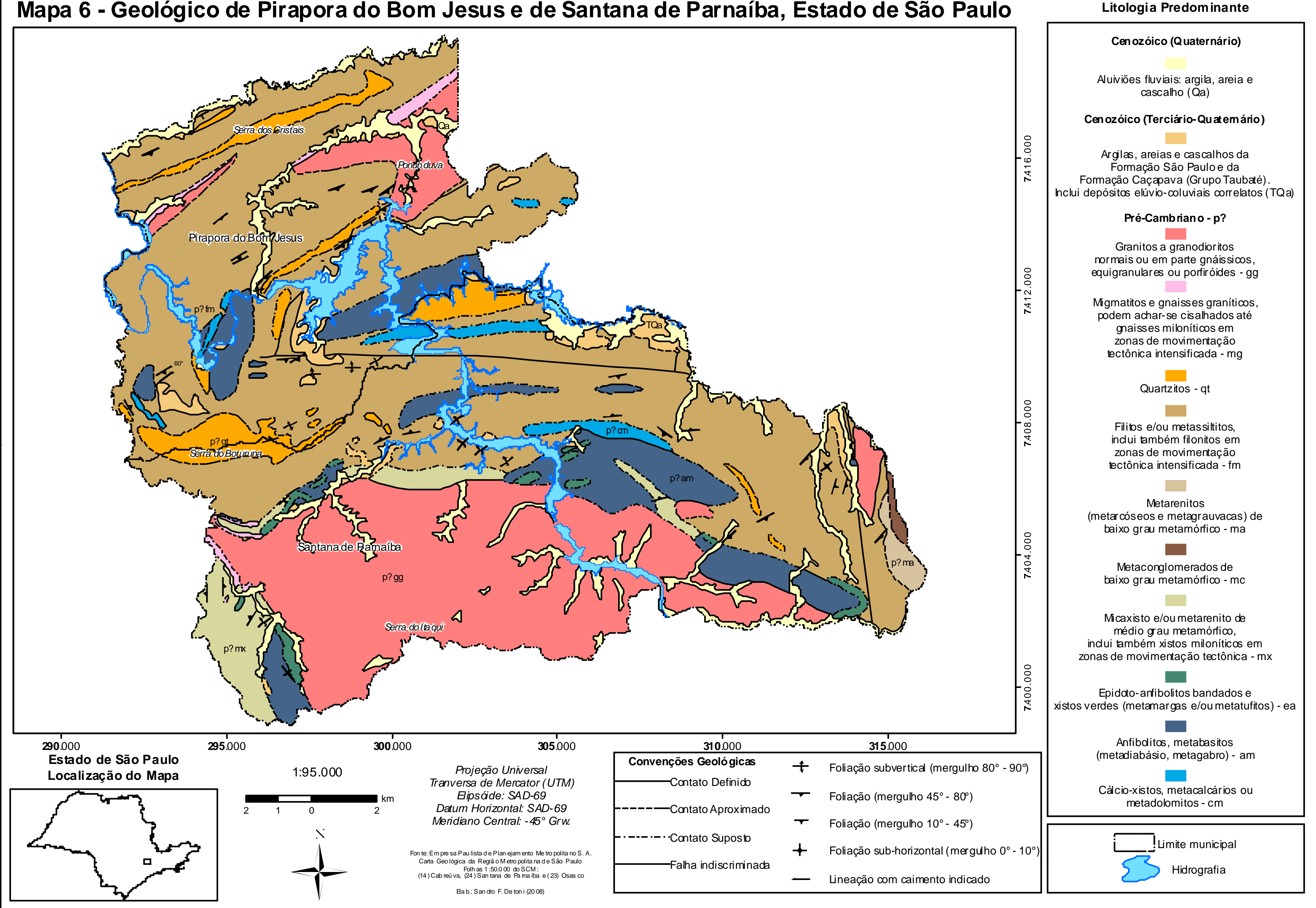


Assim, a complexidade litológica advém de uma seqüência metavulcanossedimentar depositada numa escala de tempo da ordem de 1,8 $\mathrm{Ga}^{23}$, que passou por uma evolução tecto-metamórfica relacionada aos eventos do Ciclo Brasiliano. Destacam-se também a possibilidade de evento orogênico no Proterozóico Médio e o estabelecimento de suítes graníticas no final do Proterozóico Superior (TASSINARI et al., 1988, apud HACKSPACHER; GODOY; OLIVEIRA, 1993).

Hasui (1976a) ressalta que o caráter polifásico do Pré-Cambriano na região decorre dos eventos de magmatismos (básico pré-tectônico, granitóide sin e tardi-tectônico, granitóide pós-tectônico), de metamorfismos (regional, dois de contato, retrógrado e cataclástico) e de deformação (um ou dois de dobramento, um de crenulação e transposição, um de transcorrência). Esses eventos se vinculam ao Ciclo Brasiliano $\left(650-450 \mathrm{Ma}^{24}\right)$. "A reativação PréCambriana atingiu grandes áreas da plataforma anteriormente consolidada, o que ativou bacias de antepaís, relacionadas à evolução do cinturão geosinclinal." - tradução nossa ${ }^{25}$ - (ALMEIDA, HASUI, NEVES, 1976, p. 47).

A relação genética com os eventos do Ciclo Brasiliano faz com que a região também possua grande mergulho com orientação geral ENE. O dobramento que afetou o Grupo São Roque alinhou as estruturas principais, especialmente, em planos axiais na direção NE-SW (COUTINHO, 1972)

Os eventos descritos atribuem às rochas do Grupo São Roque distintos graus de metamorfismos, sendo também entremeadas por maciços e por batólitos de granitóides. Ao sul e a oeste de Santana de Parnaíba destacam-se, respectivamente, os batólitos de Itaqui e de São Roque, a noroeste ocorre o stock granítico de Tico-Tico e a nordeste, o do Ponunduva. Destaca-se que os limites norte e sul do Grupo São Roque possuem contatos com o Complexo Cristalino.

A análise do sistema de dobras maiores permite incluir os corpos graníticos como estruturas de anticlinórios. Coutinho (1972), ao analisar o padrão estrutural da região afirmar que: "O levantamento permitiu definir, para

\footnotetext{
${ }^{23} 1 \mathrm{Ga}=10^{9}$ (um bilhão) de anos

${ }^{24} 1 \mathrm{Ma}=10^{6}$ (um milhão) de anos

${ }^{25}$ The regenerations of the Upper Precambrian saved large areas of the formerly consolidated platform, which acted as the forelands with relation to the geosynclinal belts and regions evolved since then.
} 
- Grupo São Roque, na área estudada, uma estrutura sinclinal em dobra, do tipo similar e simétrico com plano axial orientado próximo a norte-sul e eixo caindo para norte em valores variáveis." (COUTINHO, 1972, p. 7).

O caráter polifásico e mesmo policíclico relacionados à deformação, ao metamorfismo e ao magmatismo fazem com as rochas do Pré-Cambriano no Grupo São Roque se constituam, essencialmente, de metapelitos (HASUI, SADOWSKI; CARNEIRO, 1976).

Para Hasui (1975b), a ocorrência de magmatismo básico acompanhou ou seguiu a sedimentação Pré-Cambriana, devido à identificação de metamorfismo nas rochas básicas junto com os sedimentos.

Hasui; Soares; Csordas (1978) propõem uma fase de metamorfismo regional no Ciclo Transamazônico, por volta de $2.000 \mathrm{Ma}$ que abrangeu a região da Serra do Japi. "Desse modo, a Serra do Japi e adjacências traduz uma evolução polifásica e policíclica, em eventos atribuíveis aos Ciclos Tansamazônicos e Brasiliano" (HASUI; SOARES, CSORDAS, 1978, p. 23).

No entanto, para o Grupo São Roque, identificou-se somente a fase de metamorfismo regional sintectônico do Ciclo Brasiliano que transformou os corpos de rochas básicas em fácies xisto verde a anfibolito. Nessa fase, também se estabeleceu o dobramento principal do conjunto sedimentar.

Ainda sob a dinâmica genética dos dobramentos, porém, posterior ao metamorfismo regional, o conjunto São Roque submeteu-se às intrusões de granitóides tardi-tectônicas e intrusões pós-tectônicas. Assim, a seqüência metassedimentar ectinítica se acha penetrada por vários corpos granitóides. (HASUI, 1975a; HASUI, 1975b). "Os corpos granitóides sintectônicos têm idades em torno de 600 m.a. e os pós-tectônicos, ao redor de 540 m. a." (HASUI, 1975b, p.161).

Nota-se assim que a região se caracteriza pelo estabelecimento de diversos eventos metamórficos. É possível destacar que, além do metamorfismo em fáceis xistos verde a anfibolito, identificam-se metamorfismos de contato, relacionados aos corpos granitóides, metamorfismos de contato, devido às intrusões, metamorfismos retrógrados (não definido, porém, associado ao reaquecimento durante o magmatismo) e o metamorfismo cataclástico relacionado às falhas transcorrentes. "No conjunto São Roque, o caráter anticlinorial é traduzido pela presença de faixas de 
rochas de metamorfismo regional de graus cada vez mais elevados à medida que se aproxima das intrusões." (HASUI, 1976a, p. 102). O Quadro 3, baseado no trabalho de Hasui (1978) para a Serra do Japi, procura de forma simplificada demonstrar a seqüência dos depósitos sedimentar da região.

Em síntese, de acordo com o IPT (1984), a evolução geológica do Grupo São Roque pode ser sistematizada da seguinte forma: deposição, sedimentação, metamorfismo regional e magmatismo básico, deformações dos pacotes rochosos associados ao metamorfismo e ao magmatismo ácido.

Quadro 3 - Coluna estratigráfica da região da Serra do Boturuna

\begin{tabular}{|c|c|c|}
\hline Unidade Cronogeológica & Unidade Litoestratigráfica & Características Litoestruturais \\
\hline Quaternário & - & $\begin{array}{c}\text { Depósitos fluviais em aluviões, } \\
\text { terraços e zonas de inundação. }\end{array}$ \\
\hline Terciário & - & $\begin{array}{c}\text { Depósitos fluviais semelhantes } \\
\text { aos da formação São Paulo }\end{array}$ \\
\hline \multirow{2}{*}{$\begin{array}{c}\text { Cambro-Ordoviciano Pré- } \\
\text { Cambriano Superior }\end{array}$} & $\begin{array}{c}\text { Rochas cataclásticas } \\
\text { associadas a falhas } \\
\text { transcorrentes. }\end{array}$ \\
\cline { 2 - 3 } & Grupo São Roque & $\begin{array}{c}\text { Corpos graníticos discordantes } \\
\text { petasedimentos pelíticos e } \\
\text { psáticos, alguns }\end{array}$ \\
\cline { 2 - 3 } & metaconglomerados e dolomitos \\
\hline
\end{tabular}

Fonte: adaptado de HASUI (1978)

Outro aspecto importante com relação à geologia regional decorre da distinção entre os Grupos São Roque e Açungui. Para Hasui; Sadowski; Carneiro (1976), apesar das semelhanças de litologia, de metamorfismo e da geocronologia, a divisão entre esses Grupos advém da estratigrafia diferenciada.

Essas duas unidades são separadas pela Falha de Taxaquara, que afetou os metassedimentos e rochas associadas ao fim do Ciclo Brasiliano com movimentos transcorrentes. O grande porte dos deslocamentos é atestado não só pela espessa faixa cataclástica, como pelas notáveis inflexões impostas às estruturas dos metassedimentos. (HASUI; SADOWSKI; CARNEIRO, 1976, p. 108).

Conforme o esquema apresentado é possível distinguir três unidades litológicas para a região: os metamorfitos do Grupo São Roque, os granitóides e os sedimentos Cenozóicos.

Os metamorfitos do Grupo São Roque abrangem a maior parte dos municípios, segundo os dados da Tabela 10, essas rochas predominam em, aproximadamente, $66 \%$ da área dos municípios, sendo compostos pelas 
seguintes litologia de Idade Brasiliana: xistos, filitos, quartzitos, metarenitos, metacórseos, metaconglomerados, metabasitos, calcários e dolomitos.

Sua parte central é atravessada, no sentido ENE, por ampla faixa, atingindo o rio Jundiaí, de filitos que passam localmente a micaxistos, rochas a que se associam corpos mais ou menos volumosos de quartzitos, mármores e matabasitos. Poderosas instruções granítiticas e menores corpos de anfibolito penetram nessas rochas. (ALMEIDA, 1974, p. 43).

Tabela 10 - Abrangência das unidades litológicas

\begin{tabular}{|c|c|}
\hline Unidade Litológica Predominante & \% da Área \\
\hline Grupo São Roque & $65,68 \%$ \\
\hline Granitóides & $25,35 \%$ \\
\hline Sedimentos Cenozóicos & $8,98 \%$ \\
\hline
\end{tabular}

Tabela 11 - Distribuição espacial das principais rochas do Grupo São Roque em Pirapora do Bom Jesus e Santana de Parnaíba, Estado de São Paulo

\begin{tabular}{|c|c|}
\hline Litologia Predominante & $\%$ da Área \\
\hline $\begin{array}{c}\text { Filitos e/ou metassiltitos, inclui também } \\
\text { filonitos em zonas de movimentação tectônica } \\
\text { intensificada }\end{array}$ & $45,66 \%$ \\
\hline $\begin{array}{c}\text { Anfibolitos, metabasitos (metadiabásio, } \\
\text { metagabro) }\end{array}$ & $8,78 \%$ \\
\hline $\begin{array}{c}\text { Quartzitos e Metarenitos (metarcóseos e } \\
\text { metagrauvacas) de baixo grau metamórfico }\end{array}$ & $5,22 \%$ \\
\hline Cálcio-xistos, metacalcários ou metadolomitos & 1,46 \\
\hline
\end{tabular}

O Mapa 6 demonstra que os quartzitos, ou metapsamitos, distribuem-se em pequenas unidades pelos municípios representados. Essas rochas apresentam-se em lâminas ou camadas com espessuras métricas. As lâminas podem constituir-se de seqüências rítmicas, ou a alternância de camadas quartzíticas e lâminas ou camadas metapelíticas que se alternam (HASUI, 1975b). As áreas destacadas no Mapa 6 possuem faixas com predomínio de quartzitos, com larguras de centenas de metros e extensões de alguns quilômetros, como no caso da Serra do Boturuna e na faixa de quartzitos que corresponde à Serra dos Cristais. Apesar da semelhança litológica entre os quartzitos e os metarenitos, o mapa demonstra somente uma pequena unidade de metarenitos a sudoeste de Santana de Parnaíba. A Tabela 11 evidencia que os grandes corpos de quartzitos e de metarenitos abrangem pouco mais que $5 \%$ da área dos municípios.

Os filitos, ou metapelitos, apresentam-se como a principal litologia do Grupo São Roque e abrangem a maior parte dos municípios de Pirapora do Bom Jesus e de Santana de Parnaíba. A Tabela11 demonstra que mais de 
$45 \%$ das áreas dos municípios possuem como embasamento litológico predominante os filitos. Contudo, convém destacar que, normalmente, essas rochas se encontram num nível superior aos dos quartzitos, que aparecem encaixados aos filitos sob a forma de lentes. "Muito comum é a sucessão de camadas ou lâminas de quartzito ou quartzo-filito e filito ou filito grafitoso." (HASUI, 1975b, p. 162). Destaca-se também que próximo aos granitóides os filitos cedem lugar aos xistos, resultado do metamorfismo de contato.

Os granitóides, que abrangem, por volta de $25 \%$ das unidades litológicas mapeadas nos municípios de Pirapora do Bom Jesus e Santana de Parnaíba são resultados de processos magmáticos que ocorreram em dois períodos geológicos distintos. A Suíte Granítica de Itaqui, por exemplo, faz parte da Fácies Cantareira, que se constitui num amplo batólito formado em concomitância com as rochas metamórficas, por isso, esse batólito é concordante à estrutura das rochas metamórficas do entorno. Na região também há suítes graníticas pós-tectônicas, sendo representada pelo Morro do Botucavuru, a leste de Santana de Parnaíba. Esses batólitos possuem dimensões menores e se configuram de forma discordante às estruturas, pois foram intrudidos após a formação da seqüência metamórfica e pertence ao grupo de batólitos da Fácies Itu.

Alguns estudiosos têm procurado ver nessa seqüência montanhosa da borda sul da Serrania de São Roque uma continuação da Serra da Mantiqueira. Não nos parece justificável tal interpretação, por se tratar de regiões de estrutura e origem inteiramente diversas: uma origina-se da exumação de granitos e metassedimentos da Série São Roque com o entalhe da superfície Japi, enquanto que outra é um elevado degrau de origem tectônica e estrutura predominantemente gnáissica do Complexo Brasileiro. (ALMEIDA, 1976, p. 44).

O mapa geológico de Pirapora do Bom Jesus e Santana de Parnaíba também representa a distribuição de alguns setores de cobertura Cenozóica (Terciária e Quaternária), que se distribuem em pequenas unidades nas planícies fluviais. Tais coberturas compõem, por volta de, $9 \%$ das unidades litológicas mapeadas. 


\subsection{ASPECTOS GEOLÓGICOS DA SERRA DO BOTURUNA}

A ANT da Serra do Boturuna possui como litologia predominante os metamorfitos do Grupo São Roque. Estruturalmente, a Serra é formada por lentes de quartzitos intercaladas às faixas de xistos/filitos com maior espessamento da camada de quartzito na parte central da Serra. A formação desse maciço Pré-Cambriano decorre da subsidência e espessamento de antigas faixas de areias em bacia geossinclinal. Os processos epimetamórficos transformaram essas faixas de areias em quartzitos. As fases de dobramentos associam-se com a formação de batólitos e stocks de rochas magmáticas que permitiram o espessamento dos sedimentos da bacia geossinclinal. Destaca-se que entre o início do Paleozóico até o final do período Devoniano-Carbonífero, a cordilheira formada nas fases de dobramento passou por fases de dissecação. No Pós-Cretáceo, os maciços quartzíticos formados na região foram soerguidos.

Dessa forma, a evolução geológica da região do Boturuna passa pelo estabelecimento do Sinclinório de Pirapora, relacionado às diversas fases de dobramentos ocorridas no Grupo São Roque. Bergmann (1988 op. cit. JULIANI, 1992) identificou cinco fases de dobramento superimpostas.

Já o IPT (1984) reconheceu apenas três fases de dobramentos: a primeira fase foi de milonitização associada às falhas de caráter transcorrentes, sendo uma fase pouco conhecida, composta de dobras localizadas e dobras intrafoliais preservadas. De forma geral, essas dobras variam de fechadas a cerradas e, possivelmente, isoclinais de ápices espessados. A transposição nos estágios finais de formação dessas dobras, possivelmente, destruiu grande parte dos seus ápices o que pode explicar sua baixa ocorrência. Essa fase de dobramento possibilitou o aparecimento da clivagem ardosiana e da xistosidade das rochas, ocorrendo também o processo de recristalização do quartzo, da mica branca e dos opacos em metapelitos, além do aparecimento de diversos minerais. Posteriormente, ocorreu uma fase milonítica Pré-São Roque, gerando perfis abertos e fechados de ápices arredondados a subangulares em geral espessados. Essa segunda fase de metamorfismo, provavelmente, ocasionou o bandamento diferenciado como resultado da pressão. A terceira fase de dobramento caracterizou-se pelas dobras suaves a 
abertas, variando de isópacas a localmente anisópacas. Nessa fase, há formação de clivagem de crenulação plano-axial e de auréolas de metamorfismo de contato em corpos granitóides, desenvolvendo hornfels cálcio-silicáticos e xistos termometamórficos. Há evidências de que, na última fase de metamorfismo, ocorreu metamorfismo dinâmico, ou cataclástico afetando rochas metamórficas e ígneas. Pressupõe-se que os diferentes graus de moagem decorrente do aumento intensivo da cataclase geraram protomilonitos e milonitos, processo metamórfico que ocorreu, sobretudo, nas brechas tectônicas.

Pode-se também estabelecer algumas unidades litoestratigráficas específicas dentro do Grupo São Roque. Bergmann (1988 apud HACKSPACHER; GODOY; OLIVEIRA, 1983) identificou nesse grupo metassiltitos e metarritmitos pelíticos da Formação Estrada dos Romeiros, quartzitos da Formação Boturuna e metacalcários e metabásicas da Formação Pirapora.

Bergmann (1988) reconheceu, fundamentalmente os mesmos
litotipos na região do Sinclinório de Pirapora, onde caracterizou a
Formação Pirapora, basal, constituída por corpos vulcânicos e
subulcânicos de composição básica, com rochas vulcanoclásticas,
dolomitos e cálcio-filitos associados. A disposição anelar de rochas
carbonáticas com estromatólitos e brechas estromatolíticas ao redor
de um corpo vulcânico básico, com estruturas do tipo pillow lavas
(Figueiredo et al. 1982) permitiu a interpretação de tratar-se
originalmente de ilha vulcânica em ambiente marinho. Superposta a
esta ocorre a Formação Estrada dos Romeiros, formada pelos
membros arenoso e pelítico (pelitos, do grego pelos, lama), em
contato transicional com o membro carbonático da Formação
Pirapora, e sobre ela está a Formação Boturuna, grauváquica e
ortoquartzítica, com corpos de metavulcância amigdaloidal de
composição intermediária. Estas unidades foram definidas por
Bergmann (1990) em Unidade Vulcanossedimentar Basal, Unidade
Clástica Turbidítica e Unidade Clástica Alóctone. (JULIANI, 1992, p.
14).

Convém ressaltar que a Serra do Boturuna é uma dos principais fáceis do Sinclinório de Pirapora. Para Hasui (1976), esse sinclinório é delimitado pelos batólitos de São Roque e do Itaqui. As áreas periféricas desses batólitos apresentam fácies anfibolito que, pelo menos em parte, integram o Grupo São Roque e demonstram uma passagem gradativa para os metamorfitos de fácies xisto verde.

Hasui (1976) propõe que o Grupo São Roque admite duas unidades litológicas: uma unidade inferior, denominada Formação Boturuna que se caracteriza pelos filitos sericíticos, pelas intercalações de quartzito em forma de 
lentes na base e pelas rochas carbonáticas no topo. Uma outra unidade superior, que o autor designa como Formação Piragibu e apresenta como litologia básica os filitos rítmicos ou alternância de filitos e quartzitos.

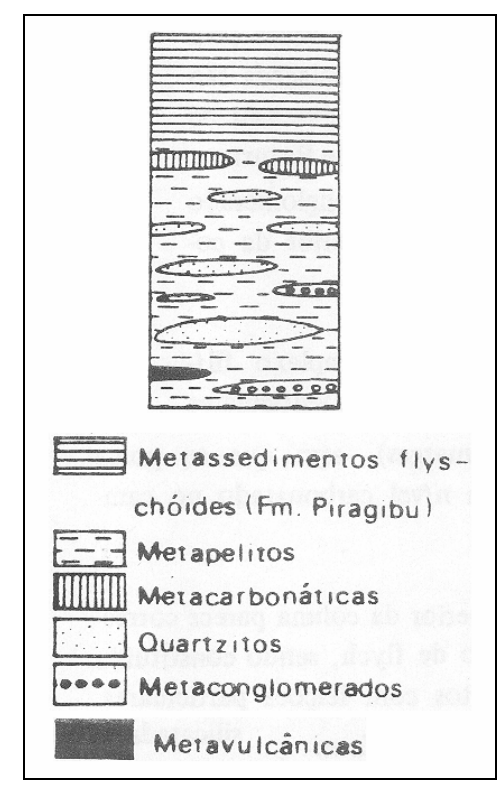

Figura 7 - Coluna estratigráfica esquemática do Sinclinório de Pirapora (Fonte: HASUI; SADOWSKI; CARNEIRO, 1976, p. 109)

A coluna estratigráfica esquemática proposta por Hasui (1976), demonstra que o Sinclinório de Pirapora na parte inferior apresenta uma base de metapelitos representados por filitos sericíticos com intercalações de quartzitos e metaconglomerados.

$\mathrm{Na}$ parte inferior existem filitos sericíticos, muito uniformes, com intercalações de quartzitos, localmente arcosianos ou ferríferos, às vezes com estratificação cruzadas. Essas intercalações são ocasionalmente muito potentes e extensas de vários quilômetros, como na Serra do Boturuna. (HASUI, SADOWSKI; CARNEIRO, 1976, p.109).

A parte superior apresenta metarritmitos que possuem características de depósitos de flysch, sendo constituído de metassedimentos com feições particulares. No conjunto, tem-se a impressão de existir uma alternância de camadas ou lâminas de diferentes composições. (HASUI, 1975b). Há, dessa forma, uma estrutura gradual que evolui de parte arenosa ou siltosa na base para uma estrutura argilosa no topo. "A recristalização metamórfica transformou essas camadas em quartzitos e filitos sericíticos, que simulam uma alternância rítmica." (HASUI, SADOWSKY, CARNEIRO, 1976, p. 109). 


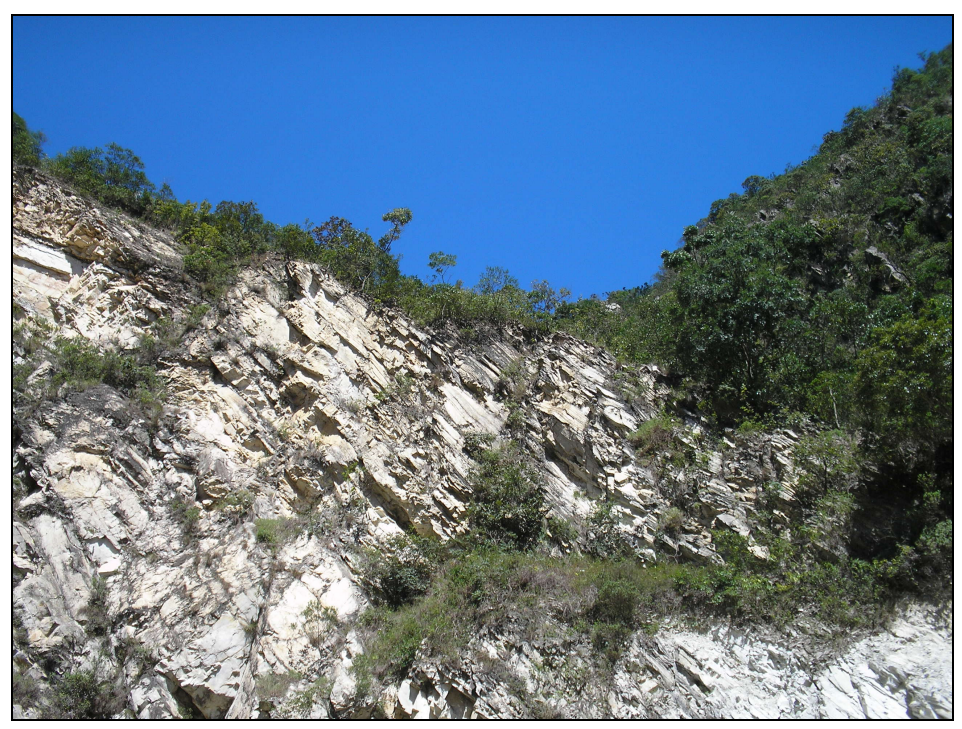

Figura 8 - Estrutura laminar e seqüência rítmica do embasamento quartzítico da Serra do Boturuna (Sandro F. Detoni, abril de 2008)

Num contexto mais amplo, caracteriza-se a Formação Boturuna pela ocorrência de metarenito arcoseano que possui gradação para metasiltito, metagrauvaca e intercalações de quartzito, quartzito feldspático e metaconglomerados.

As características geológicas demonstram a complexidade litológica da região da Serra do Boturuna. Assim, o embasamento litológico da Serra traz informações sobre a história geológica do planeta, o que também pode se constituir num importante atributo para a sua preservação.

\section{CARACTERIZAÇÃo E ANÁLISE GEOMORFOLÓGICA}

\subsection{SERRA DO BOTURUNA E O CONTEXTO GEOMORFOLÓGICO REGIONAL}

O padrão geomorfológico diferenciado faz com que a Serra do Boturuna possua uma posição de destaque na paisagem regional. A evolução das suas formas de relevo é fruto de distintos processos morfoestruturais e morfoesculturais que permitem individualizar esse compartimento geomorfológico numa escala de análise local. Porém, a contextualização geomorfológica partiu da análise regional com base na formação da macrocompartimentação do relevo no Estado de São Paulo. 
A compartimentação geomorfológica do Estado de São Paulo proposta por Almeida (1974) inclui a Serra do Boturuna na Província Geomorfológica do Planalto Atlântico. A complexidade estrutural conduz ao estabelecimento de distintas fisionomias morfológicas dentro dos macro-compartimentos propostos pelo autor. Assim, nessa proposta de compartimentação do relevo, subdividiuse o Planalto Atlântico em diferentes zonas geomorfológicas, em função das suas características morfoestruturais, o que permite incluir a Serra do Boturuna na zona geomorfológica da Serrania de São Roque.

Apesar do papel fundamental dos processos morfoestruturais na individualização e caracterização genética das formas relevo, é importante também se ater aos aspectos que conduzem o seu modelado. Para isso, Ross e Moroz (1997), na elaboração do Mapa Geomorfológico do Estado de São Paulo, utilizaram uma abordagem teórico-metodológica Germano-Russo, que dispõe sobre a utilização dos conceitos de morfoestrutura e morfoescultura, ou seja, a compartimentação do relevo não incluiu somente a correlação entre a estrutura e a forma, mas também os processos esculturais que atuaram e atuam em determinado compartimento geomorfológico.

Ao considerar a metodologia de compartimentação geomorfológica proposta por Ross e Moroz (1997), o Planalto Atlântico se insere na Unidade Morfoestrutural Cinturão Orogênico do Atlântico. De natureza poliorogênica, essa unidade morfoestrutural possui diversas fases de metamorfismo regional, falhamentos e intrusões, em decorrência dos diversos ciclos de dobramentos ocorridos na região e já expostos neste trabalho. De forma geral, o Cinturão Orogênico do Atlântico é caracterizado por um escudo cristalino Précambriano, constituído por terrenos arqueados. Deve-se destacar que na região da Serra do Boturuna, as Falhas de Jundiauvira e de Taxaquara foram muito ativas no fim do Ciclo Brasiliano. Entretanto, os relevos mais altos desse compartimento geomorfológico resultam, sobretudo, da erosão diferencial, fruto de características litológicas peculiares, tal fato faz com que determinadas áreas sejam mais resistentes ao desgaste erosivo.

Nesse sentido, após as fases orogênicas da era Pré-Cambriana, a região passou por alguns ciclos erosivos. Convém destacar que entre os períodos Pós-Cretáceo e Terciário médio, o processo epirogenético, que soergueu a Plataforma Sul-americana e reativou antigos falhamentos, produziu 
escarpas e fossas tectônicas. A formação dessas feições geomorfológicas decorre dos diversos movimentos ascensionais do escudo cristalino no PósCretáceo. Esses movimentos, denominados diastrofismo epirogenético, ocasionaram uma mudança do nível de base local e os processos erosivos tornam-se mais vigorosos. Os produtos dessa erosão acumulam-se nas chamadas bacias sedimentares que, por sua vez, passaram por processos de subsidência. De acordo com Almeida (1974), os depósitos continentais carboníferos passam a ficar a mais de $4.000 \mathrm{~m}$ de profundidade sob o mar no extremo oeste. Com isso, as depressões ajudam a demonstrar a importância e o vigor dos processos erosivos sobre a configuração do modelado do relevo nas áreas circunvizinhas, ou seja, os Planaltos.

Para Ross e Moroz (1997), os Planaltos são formas residuais circundados por extensas áreas de depressões, logo, os relevos mais altos dessa compartimentação resultaram da erosão diferencial que os distintos embasamentos litológicos se submeteram. Assim, determinadas áreas possuíram maior resistência à ação química do intemperismo.

Em função dessas características, Ross e Moroz (1997) individualizaram os Planaltos existentes na faixa de dobramento do Cinturão Orogênico do Atlântico por meio da seguinte denominação: Planaltos em Cinturões Orogênicos, comumente descrito como Planalto Atlântico. Conforme se mencionou, a gênese morfoestrutural desse Planalto resulta dos resíduos de estruturas dobradas, resultado de diversos ciclos de dobramentos, metamorfismos regionais, falhamentos e extensas intrusões.

Para Ross e Moroz (1997), a diversidade na estrutura superficial da paisagem do Planalto Atlântico condiciona-se também aos diversos ciclos erosivos Pré e Pós-Cretáceo, o que permitiu o estabelecimento de algumas unidades do relevo regional. A estrutura heterogênea e os aspectos paleoclimáticos geraram uma grande diversidade de formas topográficas fisionômicas regionais, possíveis de serem subdividas com base nas características geotectônicas, litológicas, estruturais e esculturais. Nesse sentido, Ross e Moroz (1997), assim como Almeida (1974), em suas propostas de individualização do relevo, subdividiram o Planalto Atlântico em subunidades. Contudo, na proposta de subdivisão de Almeida (1974), atribui-se um peso maior às características morfológicas dos compartimentos. Nessa 
proposta, individualizou-se o relevo função da fisionomia das formas topográficas. Essa delimitação considera, predominantemente, os aspectos da estrutura geológica. Todavia, na compartimentação proposta por Ross e Moroz (1997) se considerou conjunto dos processos que configuraram o modelado atual do relevo. Assim, a Serra do Boturuna apresenta-se como um dos compartimentos da unidade do Planalto de Jundiaí. Deve-se destacar que a proposta de Almeida (1974), considerou que o Planalto de Jundiaí fazia parte do conjunto da zona Geomorfológica da Serrania de São Roque.

O Planalto de Jundiaí localiza-se a noroeste da Região Metropolitana de São Paulo. Os processos denudacionais condicionam um modelado de relevo composto por colinas e morros baixos com topos convexos e morros altos com topos aguçados. É possível distinguir dois níveis altimétricos na região: um nível alto com altimetrias ente 900 e $1.200 \mathrm{~m}$ e declividades predominantes entre 30 e $40 \%$, com possibilidade de vertentes com até $60 \%$ e outro nível altimétrico médio que varia entre 700 e $800 \mathrm{~m}$ e com declividade predominantes entre 20 e 30\%. O nível alto se condiciona pelo embasamento litológico composto por quartzitos e granitos. De acordo com Almeida (1974), o recuo erosivo da cobertura paleozóica também expõe o granito porfírico, rosado e muito quartzoso, logo, com alta resistência aos processos erosivos.

O Mapa 7 demonstra a distribuição dos níveis morfológicos na região da Serra do Boturuna. Destaca-se a relação entre as altitudes e o embasamento litológico. A Serra do Japi, por exemplo, com altitudes superiores a $1.000 \mathrm{~m}$, possui o topo sustentado por quartzitos e a base composta por granitos e se constitui num nível morfológico diferenciado. A decomposição rasa do espinhaço quartzítico da Serra do Boturuna fez com esse perfil topográfico também se destacasse na paisagem regional. Dessa forma, é possível afirmar que a adaptação topográfica na região relaciona-se, sobretudo, à estrutura litológica do embasamento, onde se destacam algumas serras e morros na paisagem regional. 


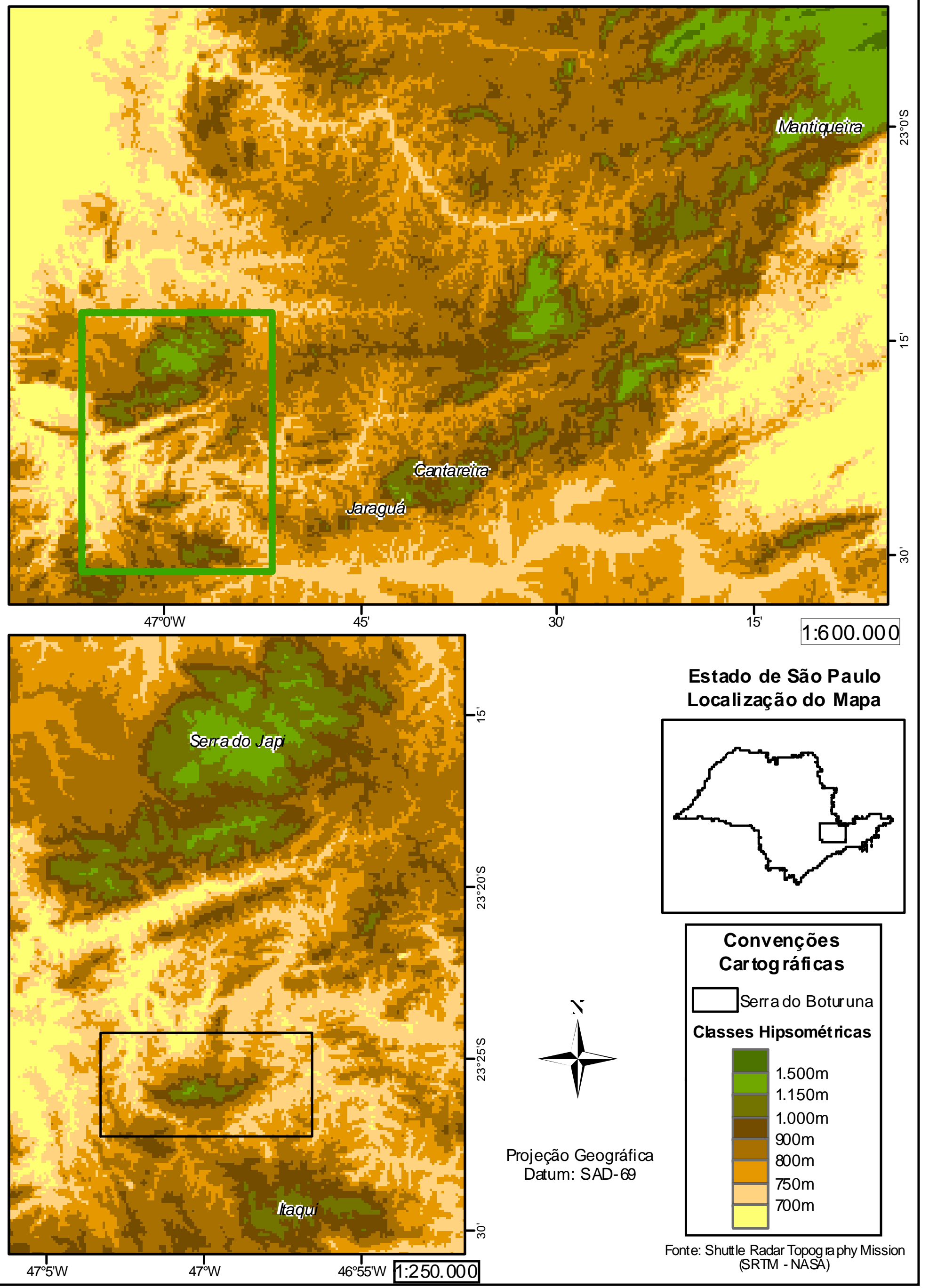


Conforme se mencionou, a distribuição dos níveis morfológicos condiciona-se à adaptação topográfica da região. De forma geral, as menores altitudes relacionam-se às coberturas sedimentares Terciárias e Quaternárias que abrangem pequenas porções nos municípios de Pirapora do Bom Jesus e de Santana de Parnaíba.

Adaptando-se rigorosamente ao basculamento dos blocos falhados e às diferenças litológicas, apenas porções exíguas aqui e ali são sedimentadas. Não houve na área condições para o desenvolvimento de largas várzeas; somente quando cursos d'água concentram sua confluência é que ocorrem pequenos alvéolos. Num desses alvéolos, logo após um dos cotovelos em ângulo reto desenhado pelo rio, alojou-se apertadamente o núcleo urbano, que se concentrou inicialmente na planície alveolar e dali se bifurcou acompanhando a margem do rio. (FRANÇA, 1975, p. 292 e 293).

A rede de drenagem da região se adaptou às estruturas do embasamento litológico. De forma geral, verifica-se que a hidrografia submetese às macroformas do relevo e possui alta capacidade de evacuar detritos de erosão, conseqüentemente, a região apresenta escassez de planícies aluviais. Quando o embasamento litológico é mais suscetível aos processos de intemperismo, a hidrografia apresenta um padrão denso que determina uma fisionomia de topos arredondados e vertentes convexas com segmentos côncavos.

Ao observa-se em maior detalhe, tanto a organização da rede de drenagem, quanto à morfologia dos morros, verifica-se que as drenagens de segunda, terceira e quarta ordens geralmente instalam-se aproveitando linhas de fraqueza que facilitam a penetração/infiltração vertical das águas pluviais, bem como encontram nessas linhas de fraqueza maior facilidade de escoamento das águas de superfície. (ROSS, 1998, p. 689).

O Mapa 8, que representa a hipsometria na ANT da Serra do Boturuna com maior detalhamento, demonstra um setor na Serra com altitudes superiores a $1.100 \mathrm{~m}$. Destaca-se que o ponto culminante da Serra possui $1.206 \mathrm{~m}$ de altitude. Por meio desse mapa, é possível diferenciar alguns compartimentos morfológicos dentro da ANT: um nível alto (acima dos 950m metros), um nível intermediário (entre 850 e 950m) e um nível baixo (entre 690 e $850 \mathrm{~m})$.

O perfil topográfico representado pelo Mapa 9 e pela Figura 10 apresenta a distribuição das altitudes, conforme o tipo de rocha do embasamento. Essa figura demonstra a situação topográfica de destaque da Serra do Boturuna e correlacionam os gradientes topográficos às litologias existentes. 


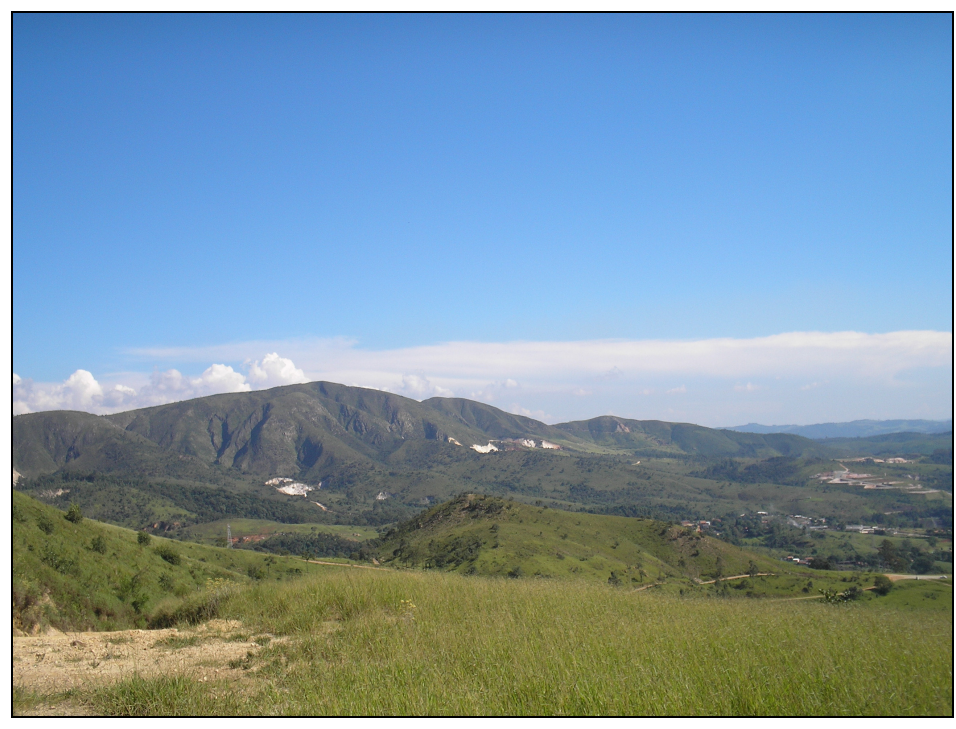

Figura 9 - Serra do Boturuna: relevo de destaque na paisagem regional (Sandro F. Detoni, abril de 2008)

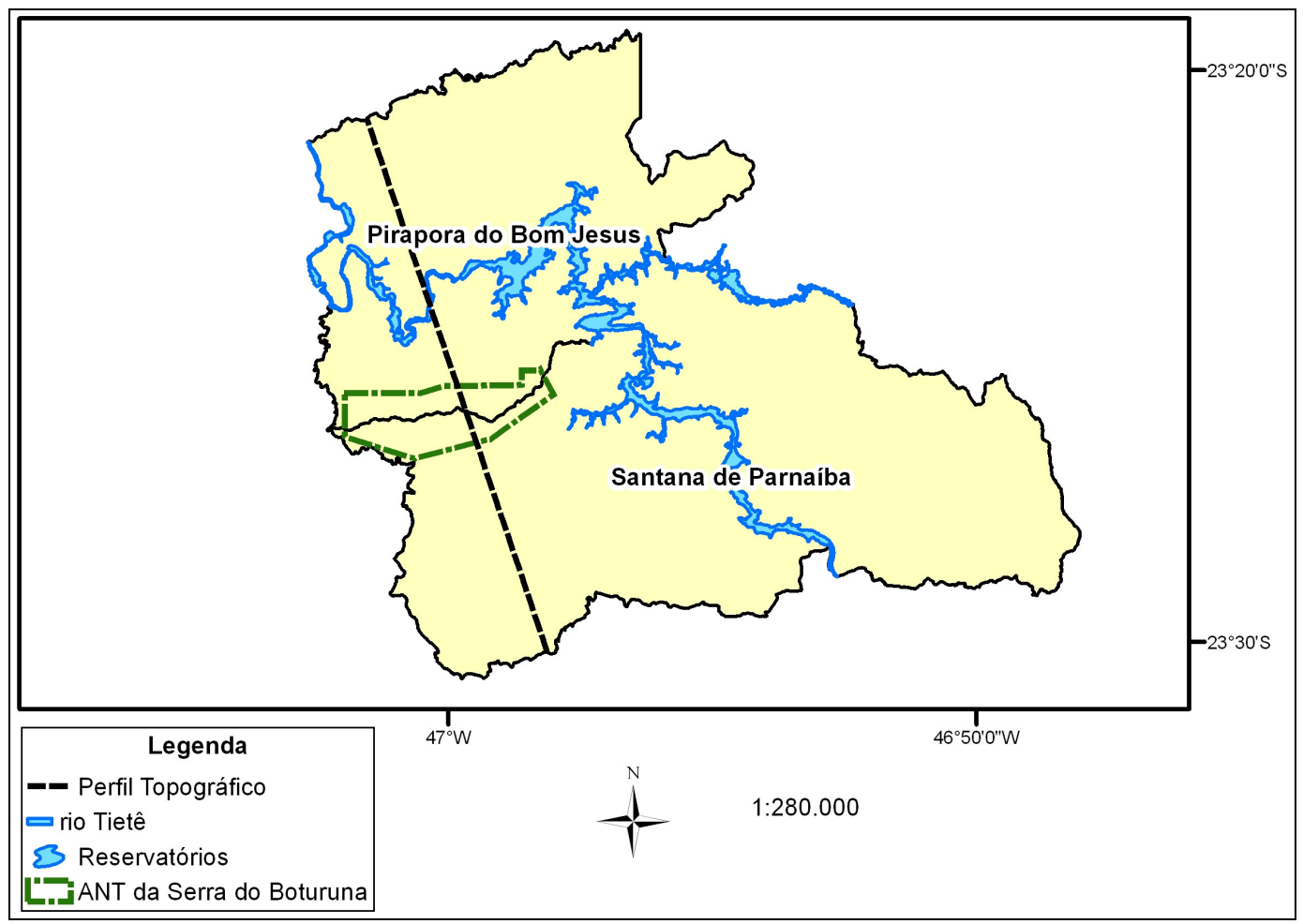

Mapa 9 - Orientação do Perfil Topográfico 


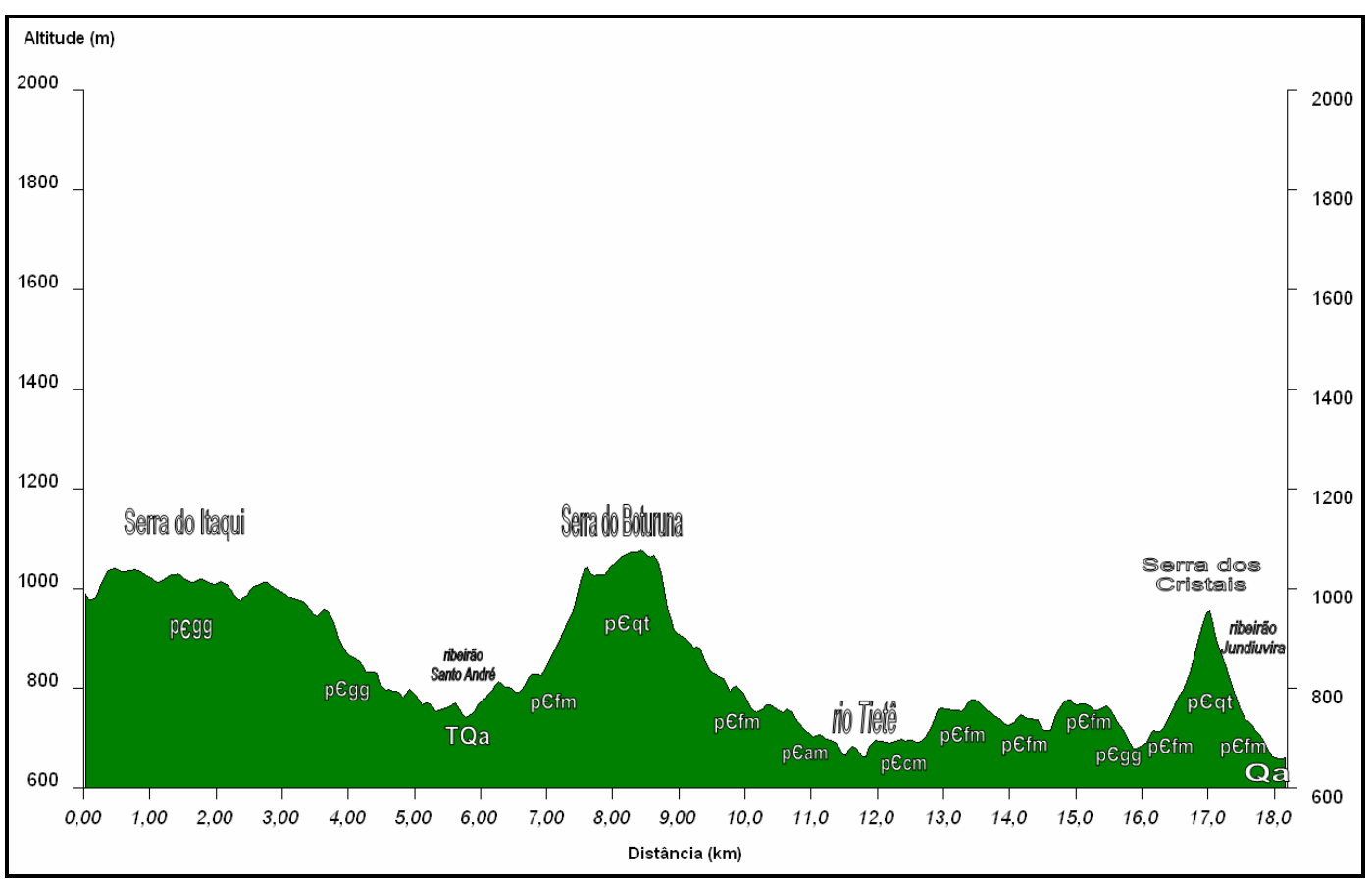

Figura 10 - Perfil topográfico esquemático da região da Serra do Boturuna

Quadro 4 - Litologias predominantes no perfil topográfico

\begin{tabular}{|c|c|}
\hline Sigla & Litologias Predominantes \\
\hline $\mathrm{Qa}$ & Aluviões fluviais: argila, areia e cascalho \\
\hline TQa & $\begin{array}{c}\text { Argilas, areias e cascalhos da Formação São Paulo e da Formação Caçapava (Grupo } \\
\text { Taubaté). Inclui depósitos elúvio-coluviais correlatos. }\end{array}$ \\
\hline p€gg & Granitos a granodioritos normais ou em parte gnáissicos, equigranulares ou porfiróides. \\
\hline pEqt & Quartzitos \\
\hline $\mathrm{p} € \mathrm{fm}$ & $\begin{array}{l}\text { Filitos e/ou metassiltitos, inclui também filonitos em zonas de movimentação tectônica } \\
\text { intensificada }\end{array}$ \\
\hline p€am & Anfibolitos, metabasitos (metadiabásio, metagabro) \\
\hline $\mathrm{p} \epsilon \mathrm{cm}$ & Cálcio-xistos, metacalcários ou metadolomitos \\
\hline
\end{tabular}

As colinas e os morros com menores altitudes e declividades possuem, geralmente, como embasamento litológico os filitos, calcários ou sedimentos Terciários e Quaternários. Essas litologias correspondem ao nível morfológico baixo. Convém destacar que a altitude tende a baixar gradualmente em direção as coberturas carboníferas no contato com a Depressão Periférica 


\section{Mapa 10 - Clinográfico da ANT da Serra do Boturuna, Estado de São Paulo}

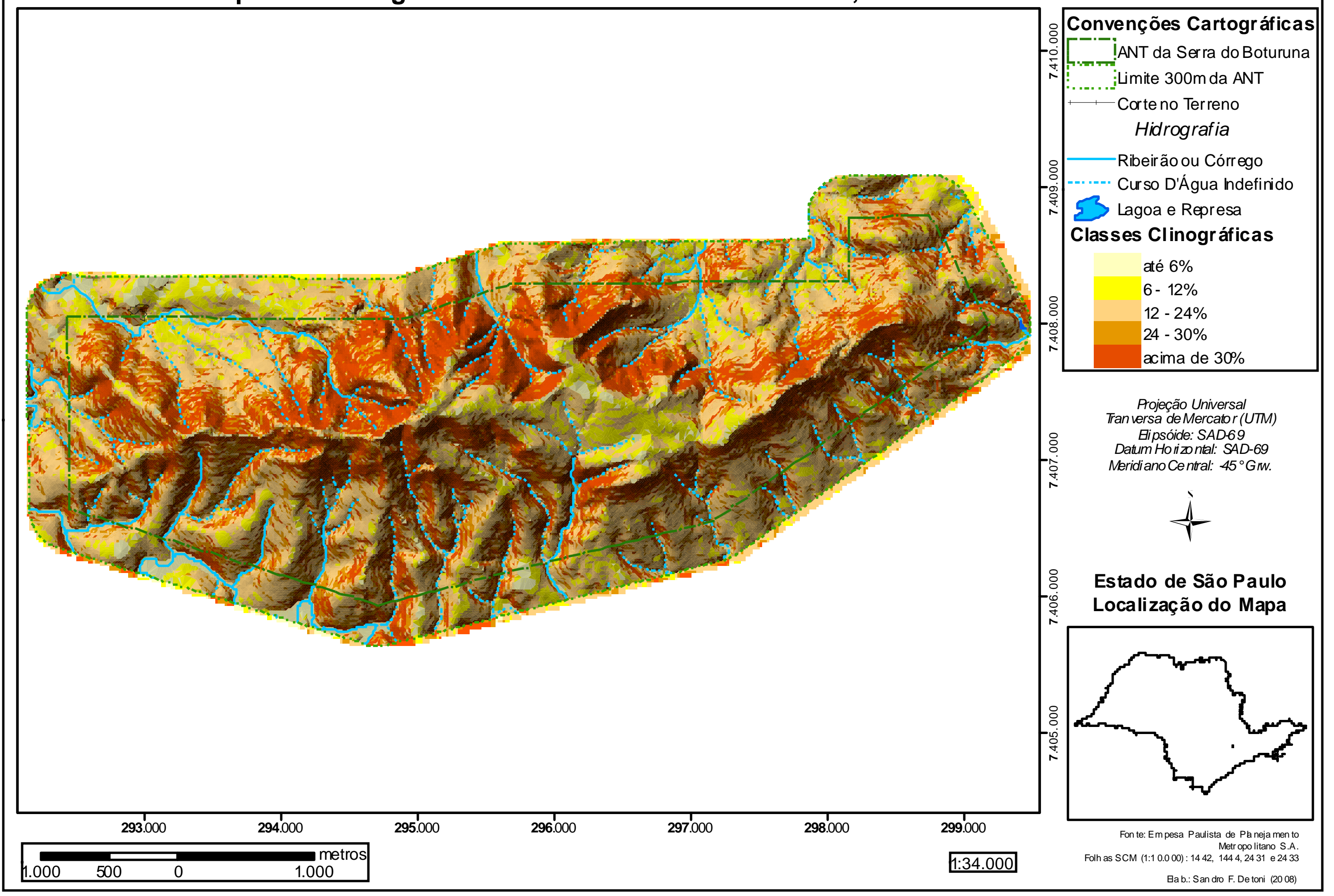


O gradiente altimétrico da Serra do Boturuna também permite o estabelecimento de altos valores clinográficos. O Mapa 10 indica que as vertentes orientadas para o norte concentram uma maior distribuição de classes clinográficas acima de $30 \%$, diferente da face sul da Serra, onde a distribuição das classes tende a ser mais homogênea. Tal fato relaciona-se ao caimento das camadas de quartzito. Possivelmente, essa característica geológica favoreceu a mineração na face norte da Serra.

Com relação à distribuição espacial das classes clinográficas, a Tabela 12 descreve que mais de $35 \%$ da área possui índices clinográficos superiores a $30 \%$, o que condiciona o estabelecimento de determinados processos geomorfológicos que implica em restrições no uso e ocupação do solo.

Tabela 12 - Distribuição quantitativa das classes clinográficas na ANT da Serra do Boturuna

\begin{tabular}{|c|c|}
\hline Classes Clinográficas & \% da Área na ANT \\
\hline Até 6\% & $5,3 \%$ \\
\hline de 6 a 12\% & $7,6 \%$ \\
\hline de 12 a 24\% & $35,2 \%$ \\
\hline de 24 a 30\% & $16,7 \%$ \\
\hline acima de 30\% & $35,3 \%$ \\
\hline
\end{tabular}

\subsection{QUESTÃO DOS NÍVEIS DE APLAINAMENTO}

Pode-se também propor que os níveis morfológicos identificados no Planalto Atlântico decorrem de diferentes fases, ciclos ou superfícies de erosão. Almeida (1974) considerou a Serrania de São Roque como uma feição típica de Planalto Cristalino. De acordo com esse pesquisador, essa feição geomorfológica é o mais típico entre os Planaltos Cristalinos Paulistas, em razão da diversidade na sua forma e na sua estrutura. $O$ autor atribui sua formação às superfícies de aplainamento do Itaguá, ou Pré-Permiana e do Japi, ou das Cristas Médias associada ao Terciário Inferior.

No contexto geral, o Planalto Atlântico constitui-se por topos convexos e pequenos maciços montanhosos altos e irregulares que conservam indícios de antigas superfícies de aplainamento, por exemplo, a superfície de aplainamento do Japi, da qual faz parte a Serra do Boturuna. 
Ao analisar as unidades regionais do relevo do Planalto Atlântico, tornase útil considerar outras concepções teóricas sobre a formação dos níveis morfológicos. As feições atuais do relevo no Planalto Atlântico resultam do soerguimento diferenciado da superfície do Japi e do seu posterior processo de erosão diferencial. O processo de intemperismo, que atuou de forma mais eficaz nas rochas menos resistentes como o xisto, fez com que a massa de quartzitos sobressaísse na paisagem local. Tal processo pode sugerir a identificação na região algumas fases de aplainamento.

[...] vários autores reconheceram regiões de cimeira subniveladas, cada qual interpretadas como vestígios de um ciclo de aplainamento. Coube a Almeida (1964) mostrar que todas compunham uma única superfície, desnivelada por falhamentos escalonados no que mais tarde reconheceu como a Antéclise da Serra do Mar. (ALMEIDA, 1975 apud IPT, 1981, p. 23).

A literatura sobre o tema destaca três ou quatros fases de aplainamento.

Além das fases mencionadas, propõem-se ainda a Superfície de Campos (Cretácea) e a Neogênica, ou do Alto Tietê, ou ainda Superfície de São Paulo (Terciário Superior e Quaternário Inferior).

As superfícies de aplainamento (superfícies de erosão ou níveis de erosão) podem ser de diversas origens e podem envolver processos poligênicos tais como flutuações climáticas e deformações tectônicas Cenozóica. Considera-se que a superfície de aplainamento do Japi, por exemplo, é de origem Pós-Cretácea e possui relação com as movimentações tectônicas Terciárias, denominadas reativação Wealdeniana. Almeida (1955 apud IPT, 1984) atribuiu a formação da Bacia Tectônica de São Paulo como reflexos das movimentações de caráter normal de bloco de falha ao longo da Serra da Cantareira. "A Superfície do Japi, que nivelou os cimos mais altos da região da Serra da Mantiqueira, foi deformada durante a evolução da Antéclise da Serra do Mar, cujo eixo maior tem direção NE-SW." (IPT, 1981, p. 43). Para Almeida (1974), a deformação ocasionada pela tectônica Cenozóica na Superfície do Japi permitiu o estabelecimento de superfícies mais altas (Mantiqueira e Bocaina). Dessa forma, o autor destaca que a Superfície do Alto Tietê possui sua morfogênese relacionada ao rebaixamento por erosão da Superfície do Japi.

Para Ross (1992), não se pode estabelecer uma relação direta e absoluta entre as superfícies de aplainamento, os diferentes níveis 
morfológicos ou topográficos e as idades das formas. É possível generalizar para algumas regiões, que os níveis aplainados ou retinilizados dos topos e cinturões orogênicos são testemunhos de fases erosivas antigas (PréCenozóico), diferente das depressões e das superfícies embutidas nas bordas das grandes bacias sedimentares que são de idades mais recentes (Terciário e Quaternário). Ab’Sáber (2003) propõe que a intensidade dos processos morfogenéticos ligados aos ciclos erosivos ocorridos na região dificulta a identificação das superfícies aplainadas, ou intermontanas, patamares de pedimentação e eventuais terraços.

Nesse sentido, os níveis morfológicos podem ser considerados produtos da diferença de velocidade do rebaixamento/escuturação do relevo, juntamente com as deformações de caráter tectônico. Tal hipótese se baseia da pouca expressividade dos depósitos Cenozóicos em volume e extensão. Dessa forma, há correntes metodológicas que atribuem aos processos esculturais químicos a responsabilidade pela morfogênese exógena dos morros e serras do leste Paulista. "Os processos tectônicos, pós e pré-cretáceos foram determinantes no condicionamento estrutural da faixa leste do Estado, e esta por conseqüência são altamente condicionadoras da configuração das formas do relevo." (ROSS, 1998, p. 688).

Os processos tectônicos Cenozóicos representam um importante papel na configuração dos níveis morfológicos atuais, devido às mudanças do nível de base em distintas escalas de abrangência. Contudo, a complexidade litoestrutural do Planalto Atlântico impõe certos limites para a identificação dos ciclos de erosão.

É possível estabelecer que o alinhamento dos topos possua relação com as fases erosivas do Pré-Cenozóico, em função das variações litológicas e de seus arranjos estruturais, o que determinou significativas diferenças altimétricas, condicionadas pelo rebaixamento desigual do terreno. 


\section{O CONTEXTO MINERÁRIO}

\subsection{MINERAÇÃO NO ESTADO DE SÃO PAULO}

Ao considerar que os principais impactos negativos sobre a paisagem da Serra do Boturuna relacionam-se aos empreendimentos minerários instalados na região, efetuou-se a análise desse setor econômico com o intuito de verificar as correlações entre a exploração dos recursos minerais, a preservação de áreas naturais e o contexto da mineração no âmbito metropolitano.

Junto com a obrigação legal em recuperar as áreas degradadas, destaca-se a importância estratégica do setor minerário. O art. 214, inciso IV, da Constituição do Estado de São Paulo, dispõe que compete ao Estado:

Fomentar as atividades de mineração, de interesse sócio-econômico para o Estado, em particular de cooperativas, pequenos e médios mineradores, assegurando o suprimento de recursos necessários ao atendimento da agricultura, da indústria de transformação e da construção civil do Estado, de maneira estável e harmônica com as demais formas de uso e ocupação do solo e atendimento à legislação ambiental. (Constituição do Estado de São Paulo, Seção III, Art. 214, Inciso IV).

A estrutura econômica diversificada e os distintos compartimentos litológicos permitem que o Estado de São Paulo exerça uma posição de destaque na produção mineral nacional. Com relação ao potencial minerário, o Estado possui dois grandes domínios litoestruturais: o Complexo Cristalino e a Bacia do Paraná (Mapa 11). Tais domínios são compostos de distintas litologias formadas em diferentes períodos da evolução geológica da Terra.

A estrutura litológica do Complexo Cristalino possui as rochas mais antigas do Estado, compostas por unidades litológicas formadas no Arqueano, no Proterozóico e no Eo-Paleozóico. Algumas áreas estão encobertas por sedimentos Terciários e Quaternários. Encontram-se também pequenas intrusões mesozóicas distribuídas por esse domínio litoestrutural.

Já, a coluna estratigráfica da Bacia do Paraná é composta, essencialmente, por unidades sedimentares Fanerozóicas do Devoneano, do Permo-Carbonífero, do Cretáceo e do Triássico. Além das unidades sedimentares, esse domínio litoestrutural também possui unidades vulcânicas e instrusivas mesozóicas. 
No Complexo Cristalino encontram-se uma parcela significativa dos empreendimentos minerários do Estado. As características litológicas desse setor condicionam uma grande diversidade mineralógica e importante potencial de exploração mineral com destaque para as rochas do Grupo Açungui e do Grupo São Roque.

O Grupo Açungui pode ser subdividido no Complexo Embu e no Complexo Pilar. Conforme descrito, as litologias presentes nesse Grupo formaram-se no Proterozóico Superior, sendo representadas, sobretudo, por migmatitos, migmatitos gnáissicos, quartzitos, micaxistos e metarenitos. Porém, tal grupo, "Constitui-se de filitos e xistos essencialmente, com intercalações de rochas calcárias (calcários, dolomitos, rochas calcossilicáticas e calcoxistos), quartzitos, metaconglomerados, metabasitos, gnaisses e formação ferrífera." (SÃO PAULO, 1981, p. 18).

Um dos principais bens minerais do Grupo Açungui é o chumbo sob a forma de galena. Esse mineral apresenta-se associado com o zinco (blenda), cobre (calcopirita, calcosina e covelina), estibnita, arsenopirita, pirita e pirrotita, prata e ouro. No Grupo Açungui também há faixas de rochas calcárias com intensa exploração (SÃO PAULO, 1981).

O Grupo São Roque é constituído, sobretudo, por filitos e xistos. Essas rochas são intercaladas por quartzitos, rochas calcárias (calcários, dolomitos, rochas calcossilicáticas e calcoxistos), metaconglomerados, metarcóseos, metabasitos, anfibolitos e metavulcânicas (SÃO PAULO, 1981). Esse grupo também apresenta alguns bens metálicos. Na região de Pirapora do Bom Jesus, por exemplo, há magnetita em forma de veio encaixada em filitos e quartzitos adjacentes ao stock metabásico. Destaca-se também o ouro em veios de quartzo com sulfetos associados, além do cobre e manganês.

Entre o fim do Proterozóico e o Eo-Paleozóico desenvolveram-se no Complexo Cristalino os granitóides, ou suítes graníticas sintectônicas, e as rochas cataclásticas, que se relacionam às falhas geológicas desse domínio litoestrutural. Os granitóides fornecem a maior parte da brita produzida no Estado. Um aspecto importante sobre a exploração dessas suítes graníticas relaciona-se ao fato de que grande parte das explorações minerárias dessas rochas encontram-se na RMSP. 


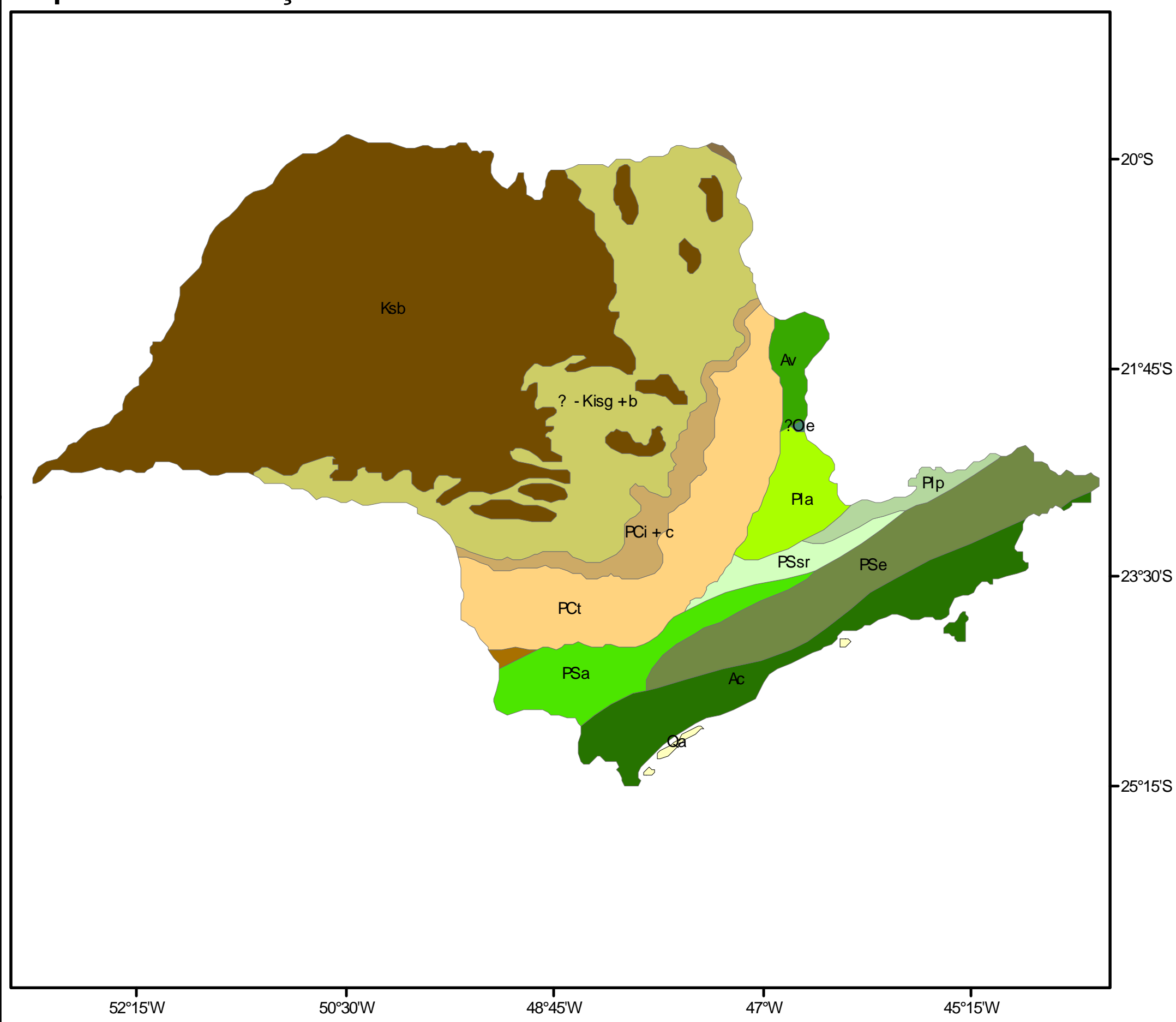

Unidades Litoestrutruais

Bacia do Paraná

Grupo Bauru - Ksb

Grupo Canastra

Grupo Paraná

Grupo Passa-Dois - PCi + C

Grupo São Bento - ? - Kis g + b

Grupo Tubarão - PCt

Complexo Cristalino

Complexo Costeiro - Ac

Complexo Embu - PSe

Complexo Varginha - Av

Formação Eleutério - ? Oe

Grupo Açungüi - PSa

Grupo Amparo - Pla

Grupo Paraíba do Sul - PIp

Grupo São Roque - PSsr

Sedimentos Quatemários

Depósitos Costeiros - Qa

Não foram representados os diques diabásicos, as intrusões alcalinas e as unidades cenozóicas

(exceto alguns depósitos costeiros)

Projeção Geográfical Datum Ho izo ntal: SAD-69 Meridiano Central: $45^{\circ} \mathrm{Gm}$.

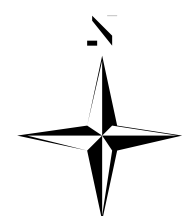

Escala Aproximada

$1: 5.000 .000$

Fonte: Ma pa de Jazidas e Ocorrências Mne ra is do Estado de São Paulo Pró-Minério/Promoceti São Paulo (1981) 
Essas características demonstram o importante potencial minerário do Estado. De acordo com o anuário mineral do DNPM, em 2005, o Estado de São Paulo obteve a quarta maior produção mineral comercializada no país. (DNPM, 2006). A representatividade da produção Estadual é dada, principalmente, pelas substâncias não metálicas que são utilizadas nas mais diversas demandas, com destaque na produção de insumos minerais utilizados na construção civil.

Entre outros bens minerais, o Estado de São Paulo destaca-se pela produção bruta de areias, sendo o maior produtor nacional, rochas britadas, cascalhos e calcários (Tabela 13). O crescimento da metrópole e a conseqüente necessidade de recursos minerais utilizados na produção industrial e na construção civil permitiram o forte desenvolvimento do potencial minerário do Estado. Os dados da Tabela 13 demonstram a importância da exploração mineral dos minerais não metálicos.

Conforme mencionado, a maioria das rochas britadas é obtida pela exploração dos granitóides (granitos, gnaisses e migmatitos). Tais formações rochosas estão presentes no Embasamento Cristalino, sendo encontradas, sobretudo, nas Suítes Graníticas, no Grupo São Roque e no Grupo Açungui. Já a areia é obtida por meio da exploração de distintos tipos litológicos. A exploração de tal substância possui diversos empreendimentos na RMSP.

A areia para utilização na construção civil é explorada na região da
Grande São Paulo a partir de diversos tipos litológicos, sendo as
principais fontes os sedimentos de rios, sedimentos da Formação
São Paulo, produtos de alteração de rochas graníticas e afins e
sedimentos dos leitos atuais dos rios. (EMPLASA, 1981, p. 15).

A maioria da produção mineral beneficiada das substâncias empregadas na construção civil fica no próprio Estado. Deve-se destacar que essas substâncias possuem menor valorização econômica no mercado dos minérios. Assim, o interesse fundamental da exploração desses recursos minerais atrelase ao seu amplo mercado consumidor com suas demandas relacionadas à expansão urbana. Nesse sentido, essas jazidas, mormente, concentram-se próximos aos centros de consumo, ou seja, os municípios com altos índices de urbanização, especialmente, os que compõem a RMSP. 
Tabela 13 - Maiores participações nas operações minerais do Estado de São Paulo (2006)

\begin{tabular}{|c|c|c|}
\hline Posição & Substância Mineral & Participação \\
\hline 1 & Areia & $22,92 \%$ \\
\hline 2 & Granito & $20,36 \%$ \\
\hline 3 & Calcário & $13,20 \%$ \\
\hline 4 & Basalto & $10,21 \%$ \\
\hline 5 & Água Mineral & $5,82 \%$ \\
\hline 6 & Argila & $4,76 \%$ \\
\hline 7 & Areia de Fundição & $3,66 \%$ \\
\hline 8 & Gnaisse & $3,13 \%$ \\
\hline 9 & Caulim & $2,61 \%$ \\
\hline 10 & Dolomito & $2,52 \%$ \\
\hline 11 & Areia para Vidro & $2,20 \%$ \\
\hline 12 & Diabásio para Brita & $2,19 \%$ \\
\hline 13 & Calcário Dolomítico & $1,05 \%$ \\
\hline 14 & Quartzito & $0,74 \%$ \\
\hline 15 & Saibro & $0,56 \%$ \\
\hline 16 & Filito & $0,54 \%$ \\
\hline 17 & Areia Quartzosa & $0,53 \%$ \\
\hline 18 & Argila Refratária & $0,38 \%$ \\
\hline 19 & Minério de Alumínio & $0,36 \%$ \\
\hline 20 & Areia Industrial & $0,26 \%$ \\
\hline \multicolumn{2}{|c|}{ Outras Substâncias } & $2,00 \%$ \\
\hline
\end{tabular}

Fonte: DNPM <www.dnpm.gov.br>. Acesso em: 2007

Tabela 14 - Participação do Estado de São Paulo na produção de alguns bens não metálico (2005)

\begin{tabular}{|c|c|}
\hline Substância & Porcentagem da Produção Nacional \\
\hline Areia & $36,89 \%$ \\
\hline Areia Industrial & $63,86 \%$ \\
\hline Calcário & $15,56 \%$ \\
\hline Rochas (Britadas) e Cascalho & $42,87 \%$ \\
\hline
\end{tabular}

Fonte: DNPM (2006)

\subsection{EXPLORAÇÃO MINERAL NA RMSP}

A constituição das regiões metropolitanas surge da necessidade de suprir os vazios de competências e procedimentos que envolviam os serviços comuns de âmbito metropolitano. Entre outros dispositivos gerais, considerouse de competência metropolitana o uso e ocupação do solo. Para isso, elaboraram-se instrumentos legais de planejamento e gestão que consideraram as seguintes temáticas: as áreas de proteção ambiental, as áreas de preservação para a garantia da produção rural, as áreas de preservação do acervo cultural e paisagístico regional e as áreas de expansão urbana. 
Entretanto, a atividade minerária também influiu nas formas de uso e ocupação da região metropolitana e necessitou de políticas públicas para a organização do setor.

A mineração na RMSP possui um papel fundamental na composição do quadro da produção mineral do Estado. A Tabela 15 demonstra que a participação média da região metropolitana, entre 2004 e 2006, representa, em torno, de $20 \%$ da produção Estadual. A representatividade dos números faz com que os conflitos entre a mineração e o uso e ocupação do solo ainda sejam latentes, principalmente, quando há o confronto entre a mineração e a preservação ambiental, como é o caso da Serra do Boturuna.

Tabela 15 - Porcentagem de participação da RMSP na produção mineral do Estado de São Paulo (2004 a 2006)

\begin{tabular}{|c|c|}
\hline Ano & Participação da RMSP \\
\hline 2006 & $20,51 \%$ \\
\hline 2005 & $18,11 \%$ \\
\hline 2004 & $18,51 \%$ \\
\hline
\end{tabular}

Fonte: DNPM (2004; 2005; 2006)

Nos arredores da cidade de São Paulo se estabeleceram os primeiros núcleos mineradores do Estado. Este trabalho já expôs que o início de tal atividade foi com a exploração aurífera, no século XVI, com os registros dessas explorações na região do Jaraguá, na Capital. "Achamos mais provável que as principais ocorrências de ouro tenham sido descobertas entre os anos de 1588 e 1887, sendo que algumas destas ocorrências já eram conhecidas antes dessa data." (KNECHT, 1950, p. 25).

Apesar da pouca expressividade, após a fase aurífera, exploraram-se os minérios de ferro em alguns municípios que hoje compõem a região metropolitana. No século XIX, Silva e Andrada, ao analisarem o potencial mineral da Província de São Paulo, destacaram a importância da exploração do minério de ferro, principalmente na região de Santana de Parnaíba.

Uma suposta terceira fase de exploração mineral nos municípios que compõem a RMSP está relacionada à exploração de minerais não metálicos, empregados, sobretudo, nos diversos segmentos industriais e na construção civil. Conforme mencionado, a expansão urbana da RMSP criou uma crescente demanda pela exploração dos seus recursos minerais. Por isso, 
estabeleceram-se uma grande quantidade de empreendimentos minerários, nas proximidades da Capital Paulista. Posteriormente, esses empreendimentos passaram a concorrer com outros usos e ocupações do solo da RMSP. "A localização das jazidas nas proximidades de São Paulo, poupando sensivelmente o agravo do transporte, permite a adoção de técnicas poucos usuais no aproveitamento de bens minerais de baixa densidade econômica." (SÃO PAULO, 1981, p. 22).

Para se ter uma idéia da importância adquirida pela proximidade na exploração de brita, segundo a EMPLASA (1981), o frete estimado em 1979 representava $40 \%$ do custo de produção para as jazidas situadas entre 40 e 50 km da Capital.

Nesse sentido, é possível afirmar que o crescimento urbano, que fez surgir uma forte demanda por recursos minerais, e o baixo custo com 0 transporte permitiram o amplo desenvolvimento e exploração do potencial mineral da RMSP. Porém, o crescimento do setor, a falta de fiscalização e a utilização de determinadas técnicas criaram distintos conflitos.

O crescimento da metrópole fez surgir o conflito entre a atividade mineradora como as demais categorias de uso e ocupação do solo, o que envolveu também questões relacionadas à degradação do meio físico, poluição e os conflitos entre o crescimento urbano e a atividade.

Nas primeiras décadas do século $X X$, a exploração mineral era realizada, principalmente, nas áreas rurais. Contudo, a metrópole cresceu e as áreas urbanas avançaram na direção das áreas de exploração mineral. Cabe ressaltar que muitos empreendimentos contavam com uma infra-estrutura mínima para alocar seus funcionários, o que facilitou a composição de diversos bairros. Atualmente, muitos empreendimentos localizam-se em áreas urbanas ou próximas aos perímetros urbanos dos municípios que compõem a região metropolitana.

Com a disputa por espaços para o crescimento urbano e a especulação imobiliária, tornou-se necessária a criação de mecanismos de gestão para determinadas atividades na RMSP, entre outras, as relacionadas à exploração mineral.

Do ponto de vista territorial a mineração, além de produzir alterações ambientais que se estendem espacialmente além dos limites da área de extração, apresenta contradições quanto à "propriedade" do 
território pois os direitos de pesquisa e lavra, pela legislação brasileira, incidem sobre o subsolo de uma determinada área mas inviabilizam o uso do solo nesse local; (EMPLASA, 1981, p. 13).

No entanto, a análise da estrutura da mineração na RMSP não deve ser pautada somente nos impactos ambientais causados por tal setor, é necessário ressaltar a importância das minerações para o crescimento e desenvolvimento da infra-estrutura urbana da metrópole. Assim, qualquer política territorial deve ponderar a mineração e a proteção ambiental como atributos de interesse metropolitano.

Com base nesse pressuposto, na década de 1970, os setores de planejamento buscavam uma forma para regulamentar a atividade mineral na RMSP, por meio do ordenamento e do disciplinamento dessa atividade. Para isso, necessitava-se de um estudo detalhado sobre esse setor para planejá-lo e controlá-lo, no qual o objetivo seria interagir a mineração com as demais atividades econômicas da região.

Ao considerar a atividade minerária, o planejamento metropolitano integrado encontrava um problema de ordem jurídica, pois, na época, as distintas jurisprudências do setor possuíam seus instrumentos de controle somente por legislação específica da União. Entretanto, em setembro de 1976 foi estabelecido um convênio entre o DNPM e a Secretaria de Estado dos Negócios Metropolitanos (SNM) para elaboração do Plano Diretor de Mineração da Região Metropolitana de São Paulo. Entre outros intuitos, esse plano buscava compatibilizar os planos diretores municipais com as normas e diretrizes do planejamento metropolitano. Esse objetivo tinha a intenção de harmonizar as diretrizes de uso e ocupação do solo com a exploração mineral na região metropolitana (EMPLASA, 1981).

O Plano Diretor de Mineração (PDM) culminou com um diagnóstico do setor minerário e suas relações com as demais atividades sócio-econômicas da RMSP. Foram apresentadas algumas diretrizes básicas que envolviam a mineração, o uso do solo e o controle da poluição na RMSP.

Além da SNM e do DNPM, a execução das atividades do PDM também contou com o apoio técnico da EMPLASA, na época denominada como Empresa de Planejamento da Grande São Paulo, e a Companhia de Pesquisa dos Recursos Minerais (CPRM). A estrutura de execução das atividades e os órgãos executores do PDM estão descritas no Quadro 5. 
Quadro 5 - Atribuições dos órgãos executores

\begin{tabular}{|c|c|}
\hline Órgão executor & Atribuicõos \\
\hline \multirow{3}{*}{ CPRM } & Levantamento da Produção Mineral \\
\hline & Levantamento do Potencial Mineral \\
\hline & Levantamento do Consumo Mineral \\
\hline \multirow{7}{*}{ EMPLASA } & $\begin{array}{c}\text { Leis e Diretrizes de Uso do Solo } \\
\text { Metropolitano: }\end{array}$ \\
\hline & Lei de Proteção aos Mananciais de Água \\
\hline & Lei do Zoneamento Industrial \\
\hline & Diretriz da Expansão Urbana \\
\hline & Diretriz da Produção Rural \\
\hline & Diretriz da Proteção Ecológica \\
\hline & Diretriz da Proteção ao Acervo Histórico \\
\hline \multirow{3}{*}{$\begin{array}{c}\text { CPRM } \\
\text { EMPLASA }\end{array}$} & Matriz Mineração x Planejamento Urbano \\
\hline & $\begin{array}{c}\text { Mapa de Diretrizes para a Atividade de } \\
\text { Mineração }\end{array}$ \\
\hline & $\begin{array}{c}\text { Considerações sobre Lavra e Métodos de } \\
\text { Recuperação do Solo Minerado }\end{array}$ \\
\hline $\begin{array}{c}\text { DNPM/SNM } \\
\text { CPRM/EMPLASA }\end{array}$ & $\begin{array}{l}\text { Proposições do Plano Diretor de Mineração } \\
\text { para Região Metropolitana de São Paulo }\end{array}$ \\
\hline
\end{tabular}

Fonte: EMPLASA (1981)

O convênio estabelecido para a elaboração do PDM permitiu o desenvolvimento de instrumentos técnicos, jurídicos e institucionais para o setor mineral. De certo modo, a ampliação desses instrumentos de controle ocasionou a transferência de empreendimentos minerários para outras regiões administrativas do Estado. Nesse sentido, o PDM constituía-se apenas na primeira etapa da gestão da atividade mineradora na RMSP. Entre outras etapas, foram apresentadas algumas propostas de estudos e projetos necessários ao suporte técnico-administrativo do PDM, tais como, os programas de apoio financeiro para que o minerador execute um plano de extração visando à recomposição do solo ou da paisagem, os estudos técnicos destinados ao estabelecimento de normas para a recomposição do solo e o projeto de ordenação dos núcleos minérios com problemas críticos.

O levantamento minerário, econômico, territorial e ambiental da RMSP resultou na elaboração do mapa de potencialidade mineral da região. Por meio desse levantamento também foi possível estabelecer as diretrizes para a mineração por meio do estabelecimento de uma matriz normativa que compatibilizasse a mineração com os demais usos e ocupações do solo. Devese destacar que o PDM e seus instrumentos de controle não proibiram a mineração em grande parte do território metropolitano, mas desenvolveram condicionantes técnicos para a sua execução. 
Antes da elaboração do PDM, alguns instrumentos jurídicos já procuravam estabelecer diretrizes para o uso e ocupação do solo da RMSP. As principais jurisprudências que incidiam sobre o uso do solo metropolitano na época eram: a Lei de Proteção aos Mananciais e o Zoneamento Industrial Metropolitano. Apesar da importância, o aparato legal desses instrumentos não colocavam restrições significativas à atividade mineral.

A legislação de proteção aos mananciais de água, embora atingindo grande extensão (perto de $50 \%$ da Região Metropolitana de São Paulo), praticamente não impede, senão nas áreas de 1⿳亠丷a. Categoria, a atividade mineral. A legislação industrial, por sua vez, à discrição das leis municipais, abre a possibilidade de localização de minerações em quaisquer das zonas industriais, com exceção das ZEI. (EMPLASA, 1981, p. 40).

Assim, as figuras jurídicas e ou situações de controle existentes até então não implicavam numa imposição de normas para a mineração na maior parte do território metropolitano. Quando a área de mineração se enquadrasse em alguma categoria mais restritiva dessas figuras jurídicas, os instrumentos restritivos utilizados implicavam nos parâmetro de controle da urbanização com a incidência de aspectos genéricos do assentamento urbano relacionados à densidade bruta, cotas consideradas no dimensionamento dos serviços e outros indicadores, ou seja, não excluíam a mineração de forma qualitativa (EMPLASA, 1981).

Por isso, o PDM desenvolveu estudos para a elaboração de novas figuras jurídicas. Foram criadas algumas situações de uso do solo metropolitano, segundo os quais, o estabelecimento de empreendimentos minerários seria condicionado a estudos mais aprofundados. Essas áreas foram:

- Áreas de proteção ambiental;

- Áreas de preservação para a garantia da produção rural;

- Áreas de preservação do acervo cultural e paisagístico regional;

- Áreas de expansão urbana metropolitana.

Já a extensão e os controles das áreas de proteção ambiental, de garantia da produção rural e de expansão urbana tendem a impor à atividade mineradora nelas contida restrições mais fortes. As áreas de preservação do acervo cultural e paisagístico, embora via de regra de menor extensão, podem, pelo alto grau de especificidade e detalhamento dos controles de nível metropolitano que pressupõem, no caso de sobreposição em áreas de jazidas, interferir na atividade mineradora até em nível excludente. (EMPLASA, 1981, p. 40). 
As figuras jurídicas propostas definiam alguns critérios para 0 estabelecimento da mineração nessas áreas específicas, consideradas de interesse metropolitano. Apesar de um importante instrumento de planejamento e gestão, essas figuras jurídicas, ou situações de incidências de controle metropolitano, não foram transformadas em lei, sendo sempre tratada como diretrizes de planejamento.

Esse Plano, cujo objetivo básico era criar condições para o
desenvolvimento da atividade de maneira integrada ao planejamento
metropolitano, visava, principalmente, assegurar o suprimento de
matérias-primas para construção civil, amenizando as seqüelas
próprias da atividade. Para tanto, indicava quais medidas
precisariam ser instituídas imediatamente, e quais estudos seriam
necessários ao estabelecimento e aprimoramento de normas a
serem definidas pelo poder público, nas quais se incluíam, de forma
inovadora no país, a obrigatoriedade da recuperação da área
degradada pela atividade e o prazo para os trabalhos de lavra, além
da exigência do parecer da CETESB como pré-requisito para a
expedição das licenças municipais. (POLETO, 2006, p. 186).

A pressão do setor minerário para romper o convênio foi um dos principais entraves para a criação dos instrumentos normativos. A base jurídica necessitava da constituição de um Conselho Diretor de Mineração que nunca foi implantado plenamente. A valorização dos aspectos ambientais em detrimento aos aspectos técnicos fez com que o órgão de planejamento metropolitano diminuísse sua participação sobre a legislação mineral. Assim, a Secretaria do Meio Ambiente passou a exercer um maior papel em relação ao licenciamento e o controle ambiental da atividade mineral. Mesmo com a estrutura institucional montada, o convênio foi cancelado na década de 1990 e os procedimentos de licenciamento da atividade mineral passaram a ser executados, exclusivamente, pela CETESB.

Como o PDM é considerado um instrumento de planejamento e gestão, para a análise da atividade minerária nos municípios de Pirapora do Bom Jesus e Santana de Parnaíba, utilizou-se as seguintes temáticas desse Plano: potencialidade minerária, diretrizes para a mineração e preservação ambiental. Procurou-se utilizar as informações e os mapas do PDM com o intuito de verificar o quadro mineral da RMSP e como a Serra do Boturuna e os municípios em questão inserem-se no contexto minerário da época da elaboração do PDM.

De acordo com PDM, Pirapora do Bom Jesus e Santana de Parnaíba eram considerados núcleos mineiros com problemas críticos. Os problemas 
que envolviam ou envolvem esses núcleos eram de ordem técnico-operacional e de ordem legal. Por isso, o Plano propusera a organização desses núcleos por meio de Projetos de Ordenação de Núcleos Mineiros.

Tais projetos estariam voltados basicamente ao estudo de todos os problemas que envolvem esses núcleos, sendo seus resultados importantes na definição de mecanismos de apoio a serem adotados pelo Poder Público. Surgem de imediato, como áreas merecedoras de estudos dessa natureza, a região compreendida entre Pirapora do Bom Jesus e Santana de Paranaíba e região sul de Mauá. (EMPLASA, 1981, p. 59)

Conforme descrito, a atividade de exploração mineral em Pirapora do Bom Jesus e Santana de Parnaíba possuía problemas críticos relacionados à gestão e ao controle legal. Portanto, o crescimento metropolitano, a necessidade de preservar os remanescentes paisagísticos e a execução de instrumentos jurídicos ambientais mais rigorosos expôs, de forma mais clara, os conflitos e os distintos problemas relacionados à atividade minerária.

A Serra do Boturuna torna-se um dos exemplos de situação conflituosa que envolve a exploração mineral e a preservação ambiental, pois, da mesma forma que o Boturuna possui importantes atributos ambientais e paisagísticos, também possui alto potencial minerário.

Com relação a esse potencial, segundo o PDM da RMSP, o Boturuna apresenta um potencial efetivo para os quartzitos, para as rochas silicificadas e cataclásticas e para os metarenitos, que incluem também os metasiltitos.

De acordo diretrizes para a atividade mineral, na maior parte do Boturuna a mineração era permitida. Entretanto, há alguns núcleos em que tal atividade não foi permitida, sobretudo, na porção Sul da Serra, em Santana de Parnaíba. Interpreta-se que essa restrição relacionava-se à vegetação, ao tipo de uso e ocupação do solo e aos problemas de ordem técnica. Deve-se ressaltar que o PDM da RMSP foi elaborado antes do tombamento da Serra do Boturuna. Considerados pela EMPLASA como distritos mineradores, Pirapora do Bom Jesus e Santana de Parnaíba contaram com PDM específicos. 


\subsubsection{Plano diretor de mineração para o município de Pirapora do Bom Jesus - SP}

Em alguns municípios da RMSP, optou-se pelo detalhamento da atividade minerária por meio da elaboração de um plano diretor de mineração no âmbito municipal.

Dentre os municípios considerados prioritários para a elaboração de um Plano Diretor de Mineração Municipal, inclui-se Pirapora do Bom Jesus. A existência de grandes áreas com potencial mineral, (quartzito, calcário, filito) sua localização dentro de um tradicional centro de produção de minérios, a importância relativa da produção mineral no fornecimento de recursos minerais para a RMSP $(26 \%$ de quartzito; $63 \%$ de filito; $30 \%$ de calcário), são pontos que justificam a necessidade de detalhamento do PDM - RMSP. (EMPLASA, 1982, p. 01).

Outro fator que justificaria a elaboração de um instrumento de planejamento e de gestão da atividade minerária foram os diversos conflitos inerentes a essa atividade no município, principalmente, os relacionados à clandestinidade do setor.

Assim, em 1982, concluiu-se o PDM para o município de Pirapora do Bom Jesus, ou seja, tal instrumento de planejamento também foi elaborado anteriormente ao tombamento da Serra do Boturuna pelo CONDEPHAAT. Segundo descrito, naquele momento, a produção mineral desse município concentrava-se na exploração de quartzito, calcário e filito, com grande participação na produção dessas substâncias minerais na RMSP, conforme a Tabela 16.

Tabela 16 - Porcentagem de participação da produção mineral de Pirapora do Bom Jesus na RMSP (1981)

\begin{tabular}{|c|c|}
\hline Substância Mineral & Participação de Pirapora do Bom Jesus \\
\hline Quartzito & $26 \%$ \\
\hline Filito & $63 \%$ \\
\hline Calcário & $30 \%$ \\
\hline
\end{tabular}

Fonte: EMPLASA (1982)

O PDM de Pirapora do Bom Jesus destacava que a produção mineral no município possuía problemas da ordem técnico-operacional e de ordem legal. Os principais problemas relacionados à mineração eram os seguintes: comprometimento da qualidade da água que abastecia a população local; 
impactos ambientais e sociais causados pela utilização de explosivos próximos às áreas urbanas e o desenvolvimento desordenado da atividade.

O Plano destacava que as propostas e diretrizes para a atividade de mineração possuíam caráter dinâmico e não se constituíam como uma solução definitiva dos problemas detectados naquele momento, ou seja, o plano se constituía como uma etapa inicial do processo de planejamento da atividade.

Com relação às diretrizes para a atividade mineral na Serra do Boturuna, ao contrário do PDM para a RMSP, o plano propunha que, em grande parte da região da Serra, a mineração seria permitida com restrições técnicas. Delimitou-se também uma área que a mineração não foi permitida, por questões, relacionadas, sobretudo, ao abastecimento de água.

\subsubsection{Plano diretor de mineração para o município de Santana de Parnaíba - SP}

Com os mesmos objetivos dos demais planos diretores de mineração, em 1985, conclui-se o PDM de Santana de Parnaíba, ou seja, o plano é posterior ao tombamento da Serra do Boturuna pelo CONDEPHAAT.

Diferente do que ocorria no município de Pirapora do Bom Jesus, onde a atividade de exploração mineral concentrava-se, em grande parte, na região da Serra do Boturuna. Em Santana de Parnaíba, as minerações localizavam-se, sobretudo, na porção Sul, no batólito granítico do Itaqui, e nas áreas de ocorrência de filito, próximo aos limites da divisa municipal entre Pirapora do Bom Jesus e Cajamar.

De acordo com o PDM de Santana de Parnaíba, o Itaqui se configurava como uma das maiores áreas potenciais para a exploração de brita. "O batólito granítico da Serra de Itaqui, com uma área de aproximadamente $115 \mathrm{~km}^{2}$, constitui uma das maiores reservas de granito para brita da Grande São Paulo, sendo atualmente explorada por diversas pedreiras de grande porte." (EMPLASA, 1985, p. 30). A principal mineradora que explorava e ainda explora o granito do Itaqui é o Grupo Constran.

O Plano descreve que no município há inúmeras pequenas lentes de ocorrência de quartzito, porém, apenas algumas foram definidas como áreas 
potenciais para a exploração dessa rocha, entre as quais, destacam-se as da Serra do Boturuna.

Outra ocorrência definida como área potencial para extração de quartzito, situa-se na divisa de Santana com Cajamar (Polvilho). Neste local o quartzito apresenta-se foliado, com bandas friáveis ricas em feldspato (estéril) e bandas resistentes ricas em quartzo, que são extraídas e usadas para revestimento. (EMPLASA, 1985, p. 34).

Assim, ao contrário do que ocorria em Pirapora do Bom Jesus, os pontos de extração de quartzito, em Santana de Parnaíba, localizavam-se nesta última área. Na ocasião, havia nessa região quatro pontos de extração que produziam 200 t./mês de quartzito para revestimento (EMPLASA, 1985).

Além do quartzito e do filito, Santana de Parnaíba configurava-se como uma das principais áreas de ocorrência de calcário na RMSP. Com relação à distribuição espacial dessa substância mineral, "[...] essas ocorrências caracterizam-se por se apresentarem espalhadas ao norte do município, de maneira pontual como pequenas lentes encaixadas em meio a filitos." (EMPLASA, 1985, p. 35). Segundo Knecht (1950), esse corpo litológico de calcário ao norte de Santana de Parnaíba, já foi intensamente lavrado na década de 50, quando então produzia 60.000 sacos de cal por mês. Com relação ao contexto da atividade na década de 1980,

Através do mapeamento das áreas de mineração, pode-se
constatar a existência de oito empresas de mineração atuando no
município, explorando minerais regulamentados pelos regimes de
licenciamento e autorização de pesquisa e concessão de lavra.
Verificou-se uma empresa devidamente licenciada para extração
de brita; uma detentora de quatro decretos de lavra para extração
de filito e quartzitos; uma minerando com requerimento de
pesquisa para quartzito; uma extraindo filitos em área de terceiros
com Decreto de lavra e Alvará de Pesquisa; e quatro áreas de
extração de quartzito e filito sem qualquer processo junto ao
DNPM. (EMPLASA, 1985, p. 38).

$\mathrm{Na}$ elaboração das diretrizes para a atividade mineral em Santana de Parnaíba e, em especial na Serra do Boturuna, considerou-se o tombamento da Serra pelo CONDEPHAAT. O Boturuna foi descrito como uma área potencial para a extração de quartzito e de filito. Contudo, o plano faz menção que a instalação de novas minerações deveriam se submeter à apreciação conjunta do DNPM e do CONDEPHAAT.

O mapa de diretrizes para a atividade mineral deveria ser utilizado pela Prefeitura Municipal como um instrumento orientador para o desenvolvimento dessa atividade e serviria de base para a emissão de licença específica 
referente ao Regime de Licenciamento (Lei Federal n. 6.567/78) ou para a elaboração de pareceres técnicos nos regimes de Autorização de Pesquisa e Concessão de Lavra.

A proposta de zoneamento mineral está restrita às áreas que têm indicação de potencial efetivo (áreas onde podem existir reservas minerais que justifiquem economicamente a extração). As demais áreas do município, não abrangidas por este Zoneamento, deverão ser enquadradas na categoria "Caso Especial Fora do Potencial", onde se recomenda um estudo mais detalhado, com a participação da Emplasa, para análise da viabilidade de instalação dos empreendimentos minerais. (EMPLASA, 1985, p. 62).

Entre as propostas e as recomendações específicas, o PDM de Santana de Parnaíba contava com uma tabela que estabelecia os procedimentos técnico-institucionais a serem empregados em determinadas situações. $\mathrm{Na}$ Serra do Boturuna, por se tratar de uma área permitida com restrições do CONDEPHAAT, deveriam ser utilizados os procedimentos descritos no Quadro 6. Tais procedimentos indicavam, assim, uma participação efetiva do CONDEPHAAT para o controle da atividade de exploração mineral na Serra e se configurava como um instrumento de gestão do espaço natural. 
Quadro 6 - Procedimentos técnico-institucionais para as áreas de mineração permitida com restrições do CONDEPHAAT

\begin{tabular}{|c|c|}
\hline Situações & Procedimentos Técnico-Institucionais \\
\hline \multirow[t]{2}{*}{$\begin{array}{l}\text { Regime de licenciamento (Lei Federal } n \text {. } \\
6.567 / 78 \text { ) }\end{array}$} & $\begin{array}{c}\text { - conceder licença específica municipal } \\
\text { somente após: } \\
\text { a) manifestação do CONDEPHAAT } \\
\text { autorizando a lavra; } \\
\text { b) vistoria ao local. }\end{array}$ \\
\hline & $\begin{array}{l}\text { - assessoria SNM/EMPLASA da análise } \\
\text { dos pedidos. }\end{array}$ \\
\hline \multirow[t]{3}{*}{$\begin{array}{l}\text { Pedidos dentro do regime de Autorização } \\
\text { de Pesquisa e Concessão de Lavra }\end{array}$} & $\begin{array}{l}\text { - quando solicitada manifestação da } \\
\text { Prefeitura Municipal vincular a } \\
\text { autorização a um parecer do } \\
\text { CONDEPHAAT sobre a possibilidade } \\
\text { da lavra; }\end{array}$ \\
\hline & - visita ao local obrigatória; \\
\hline & - assessoria SNM/EMPLASA. \\
\hline Na existência de lavra em operação & $\begin{array}{l}\text { - contato junto ao DNPM para } \\
\text { verificação da situação legal, ao } \\
\text { CONDEPHAAT para avaliar a } \\
\text { pertinência desta atividade e à } \\
\text { CETESB sobre os aspectos } \\
\text { ambientais, objetivando: } \\
\text { a) regularização da situação legal a } \\
\text { partir de manifestação positiva do } \\
\text { CONDEPHAAT; } \\
\text { b) adequação dos aspectos técnicos de } \\
\text { operação se a lavra estiver causando } \\
\text { danos, segundo determinações do } \\
\text { CONDEPHAAT. }\end{array}$ \\
\hline
\end{tabular}

Fonte: EMPLASA (1985)

Para as áreas de mineração não permitida, o PDM de Santana de Parnaíba sugeriu a criação de um sistema EMPLASA/Prefeitura Municipal para a realização de vistorias periódicas para evitar o surgimento de lavras clandestinas.

\subsection{CÓDIGO DE MINERAÇÃO E LICENCIAMENTO AMBIENTAL}

O Código de Mineração em vigência foi atribuído pelo Decreto-lei Federal n. 227 de 1967. A principal alteração desse código foi dada pela Lei Federal n. 9.314/1996. Entre outros dispositivos tal lei especifica os diferentes regimes necessários para o aproveitamento de substâncias minerais: os regimes de concessão, de autorização, de licenciamento, de permissão e de monopolização. Deve-se destacar que qualquer exploração mineral é 
precedida pelo requerimento de autorização de pesquisa mineral. Essa etapa consiste em requerer a execução dos trabalhos necessários para a definição da jazida, sua avaliação e a determinação da exeqüibilidade do seu aproveitamento econômico. A autorização da pesquisa mineral é outorgada pelo DNPM que avaliará, entre outros documentos, o plano de pesquisa mineral. Após a realização da pesquisa é apresentado, junto ao DNPM, um relatório para o parecer desse órgão. A aprovação do relatório demonstra a existência de jazida e o minerador poderá requerer a concessão de lavra. Assim, dependendo da esfera administrativa ou órgão competente, a extração mineral necessita da permissão, da concessão ou da licença.

Com relação às restrições ambientais, 0 art. 16 da Lei Federal $n$. 73.805/1989 dispõe que a concessão de lavra depende do licenciamento prévio do órgão ambiental competente. No entanto, para requerer uma pesquisa mineral em áreas de conservação, também se torna necessária a prévia autorização do órgão ambiental que as administre. Assim, tal dispositivo determina que, no caso de uma Área Natural Tombada, o CONDEPHAAT emita um parecer.

Para Machado (2004), a expressão "área de conservação" merece ser entendida na sua acepção constitucional de espaço territorial especialmente protegido.

A atividade de exploração mineral provoca distintos impactos ambientais que se relacionam, sobretudo, ao tipo de substância explorada. Entre os principais impactos ambientais, há a retirada da cobertura vegetal, a alteração da topografia local, o rebaixamento de lençol freático, a contaminação de recursos hídricos, entre outros.

Destaca-se que os Estados possuem competência concorrente com a União para legislar sobre o meio ambiente e controle da poluição. Logo, qualquer exploração mineral deve possuir licenciamento do órgão ambiental Estadual.

A fase de autorização para Pesquisa Mineral não previu a obrigatoriedade da realização do EIA, que inclui a avaliação do impacto ambiental e a proposição de medidas mitigadoras a serem adotadas. Porém, a Resolução CONAMA 9/90 dispõe que a licença ambiental seja composta dessa avaliação e medida. Essa resolução exige o EIA para o exercício das 
atividades de lavra e/ou beneficiamento mineral das Classes I, III, IV, V, VI, VII, VIII e IX.

Para os minerais de Classe II, de emprego imediato na construção civil, aplica-se a normas contidas na Resolução CONAMA 10/90. Tal resolução dispõe que a apresentação do EIA e do respectivo EIA-RIMA está condicionada aos critérios do órgão ambiental competente. Se o empreendedor for dispensado apresentação do EIA-RIMA, a licença para a exploração mineral condiciona-se à elaboração de um Relatório de Controle Ambiental (RCA), de acordo com as diretrizes impostas pelo órgão ambiental competente. De acordo com o art. $3^{\circ}$.:

A critério do órgão ambiental competente, o empreendimento, em função de sua natureza, localização, porte e demais peculiaridades, poderá ser dispensado da apresentação dos Estudos de Impacto Ambiental - EIA e respectivo Relatório de Impacto Ambiental - RIMA. Para Machado (2004): (Art. $3^{\circ}$. da Resolução CONAMA 10/90).

A dispensa do EIA/RIMA não é automática, pois necessita de motivação do órgão ambiental, explicitando a natureza, a localização e o porte do empreendimento. Note-se que a introdução do RCARelatório de Controle Ambiental não foi, ainda normatizada pelo CONAMA, ficando esse procedimento, até agora, nas mãos exclusivas de diretrizes dos órgãos administrativos. (MACHADO, 2004, p. 647).

A aplicabilidade desses dispositivos jurídicos depende da eficácia do monitoramento e da auditoria ambiental das áreas de mineração. Além da clandestinidade inerente ao setor, tais instrumentos de controle, normalmente, não são aplicados, assim, as sanções descritas na legislação não são impostas.

No Estado de São Paulo, a Resolução SMA n. 51/2006 disciplina o licenciamento ambiental das atividades minerárias no Estado, integrado os procedimentos dos órgãos públicos responsáveis. De acordo com o art. 6․ da resolução, o licenciamento ambiental para as extrações minerais de até 20 ha, com volume de extração de até $5.000 .000 \mathrm{~m}^{3}$ (in situ), que implique na supressão nativa de até 20 ha, entre outros aspectos, ocorre mediante a apresentação do RCA e do Plano de Controle Ambiental (PCA), o que dispensa o EIA-RIMA.

Apesar de um dispositivo específico para as áreas tombadas, deve-se destacar que, muitas vezes, uma área de mineração possui várias poligonais minerárias com tamanho inferior a 20 ha. No tocante ao volume de extração, no 
caso de uma frente de lavra de quartzito, a extração de volumes inferiores a $5.000 .000 \mathrm{~m}^{3}$, em virtude do método de lavra, pode provocar um impacto significativo na paisagem regional, como ocorre em muitos setores da Serra do Boturuna. Essas questões, possivelmente, devem fazer parte da avaliação do órgão ambiental, antes da dispensa do EIA-RIMA.

A solicitação da licença ambiental deve ser encaminhada ao Departamento de Avaliação de Impacto Ambiental (DAIA) da SMA, quando da dúvida de impacto ambiental significativo. Ao receber a consulta o DAIA poderá manifestar a exigência do Relatório Ambiental Preliminar (RAP), do EIA-RIMA ou, ainda, remeter à análise da CETESB e do Departamento Estadual de Proteção de Recursos Naturais (DEPRN), no caso da ausência de significativo impacto.

Com relação às ANTs, o parágrafo 1ํ․ do art. 3‥, dispõe que:

A pesquisa mineral a ser realizada em áreas tombadas, Áreas de Proteção Ambiental ou áreas inseridas em Zona de Amortecimento de Unidades de Conservação de Proteção Integral, ou nos seus limites, dependerá de prévia emissão de Assentimento para Pesquisa Mineral. (Resolução SMA 51/2006, Art. 3ำ, $§ 1^{\circ}$ )

Entende-se que, no caso de uma ANT, o assentimento decorre autorização do CONDEPHAAT, que poderá solicitar o EIA-RIMA e o respectivo PRAD para outorgar a licença da atividade.

Ao considerar incompatível a atividade minerária dentro de um ANT, o Ministério Público Federal interveio na questão. Dessa forma, o CONDEPHAAT recomendou ao DNPM que indeferisse qualquer requerimento de pesquisa dentro do perímetro das áreas de tombamento ${ }^{26}$. No perímetro da ANT da Serra do Boturuna, em 2007, solicitou-se um novo requerimento de pesquisa que aguarda o cumprimento de algumas exigências por parte do minerador. Logo, possivelmente, o DNPM não considerou a recomendação do CONDEPHAAT neste caso.

Ainda com relação à resolução SMA n. 51/2006, o art. 13, parágrafo 4ํ․, dispõe que o PRAD deverá ser apresentado na forma de capítulos dos instrumentos aplicados no licenciamento ambiental.

\footnotetext{
${ }^{26}$ Informação pessoal cedida pelo engenheiro Dalmo José Rosalém do CONDEPHAAT.
} 


\subsubsection{Compensação Financeira pela Exploração dos Recursos Minerais (CFEM)}

Apesar da competência privativa da União para administrar e permitir a exploração dos recursos minerais, a Constituição Federal, no art. 20, assegura aos Estados e aos municípios a participação no resultado financeiro da exploração de distintos recursos naturais, entre os quais, os bens minerais. Tal dispositivo encontra sua aplicação por meio do instrumento da compensação financeira.

A Compensação Financeira pela Exploração dos Recursos Minerais (CFEM) substituiu o antigo Imposto Único sobre Minerais (IUM), sendo instituída pela Lei Federal n. 7.990/89. O CFEM constitui-se num instrumento jurídico-financeiro, no qual as empresas mineradoras recolhem um imposto pela exploração ou extração de recursos minerais, ou seja, é um imposto sobre a retirada de substâncias minerais da jazida, mina ou outro depósito mineral que envolva seu aproveitamento econômico. A CFEM é gerada na saída por venda do produto mineral das jazidas, na utilização do produto mineral, na transformação industrial do produto mineral ou, ainda, no seu consumo por parte do minerador. Entretanto, o fato gerador incide apenas em uma das etapas. A base de cálculo desse imposto é o faturamento líquido (com a dedução dos demais impostos, das despesas com transporte e do seguro) sobre o valor da venda do produto mineral. Se o próprio minerador for o consumidor do produto mineral, a CFEM é calculada sobre a soma das despesas diretas ou indiretas que foram efetuadas até o momento da utilização do produto mineral.

A Lei Federal n. 8.001/90 definiu os percentuais da distribuição da compensação financeira. De acordo com a substância mineral, é aplicada uma alíquota sobre o faturamento líquido, conforme o quadro a seguir: 
Tabela 17 - Alíquotas da CFEM

\begin{tabular}{|c|c|}
\hline Substância Mineral & Alíquota do CFEM \\
\hline Minério de Alumínio, Manganês, Sal-Gema e Potássio & $3 \%$ \\
\hline Ferro, Fertilizante, Carvão e Demais Substâncias & $2 \%$ \\
\hline $\begin{array}{c}\text { Pedras Preciosas, Pedras Coráveis Lapidáveis, } \\
\text { Carbonados e Metais Nobres }\end{array}$ & $0,2 \%$ \\
\hline Ouro & $1 \%$ \\
\hline
\end{tabular}

Fonte: Lei Federal n. 8.001/90

Segundo a Lei, para os produtos explorados nos municípios de Pirapora do Bom Jesus e de Santana de Parnaíba, é a aplicada uma alíquota de 2\% sobre o faturamento líquido referente à CFEM.

Ainda, segundo a Lei Federal n. 8.001/90, a distribuição dos recursos proveniente da CFEM ocorre conforme o Tabela 18, que se refere às substâncias de emprego direto na construção civil, ou no beneficiamento de matéria-prima para a indústria e produção de fertilizantes.

Tabela 18 - Distribuição dos recursos provenientes da CFEM

\begin{tabular}{|c|c|}
\hline Esfera Administrativa de Governo & Cota-Parte do CFEM \\
\hline União & $12 \%$ \\
\hline Estado & $23 \%$ \\
\hline Município Produtor & $65 \%$ \\
\hline
\end{tabular}

Fonte: Lei Federal n. 8.001/90

O município produtor é onde ocorre a extração mineral, contudo, se a extração abranger mais de um município, torna-se obrigatória o preenchimento de uma guia para especificar a proporcionalidade da produção efetivamente ocorrida em cada município.

Nos Estados e municípios, as receitas relativas à CFEM devem ser aplicadas em projetos, que direta ou indiretamente, tenha relação com a região da exploração mineral. Assim, os recursos repassados deveriam ser utilizados na melhoria da infra-estrutura, da qualidade ambiental, da saúde e da educação. Possivelmente, a maior parte das prefeituras não possui o controle do repasse da cota-parte do CFEM, que compõe o montante dos demais repasses. Logo, também não há um controle sobre a aplicação desses recursos nas áreas supramencionadas. 


\subsubsection{Imposto Único sobre os Minerais (IUM)}

O IUM, que foi substituído pela CFEM em 1989, representava uma parcela significativa na composição das receitas dos municípios de Pirapora do Bom Jesus e Santana de Parnaíba, nas décadas de 1970 e de 1980.

O IUM advém da Lei Federal n. 4.425/64 (com regulamentação pelo Decreto Federal n. 55.928/65 e pelo Decreto-Lei Federal n. 1.038/69), era o principal tributo sobre a exploração mineral, na época. Os principais propósitos do imposto consistiam em estimular o desenvolvimento do setor e evitar a bitributação (bis in idem) sobre um mesmo fato gerador, pois, anteriormente, tanto os Estados como os municípios possuíam a prerrogativa na tributação sobre a exploração mineral. O IUM definia que as cotas-parte seriam distribuídas conforme o Tabela 19. A distribuição das cotas-parte considerava critérios proporcionais de produção de minerais, da superfície territorial e da população.

O Decreto-Lei Federal n. 1.172/71, que alterou as normas do IUM, dispôs para a maior parte das substâncias minerais a alíquota de $15 \%$. Se o destino dessas substâncias fosse a exportação a alíquota seria de 4\%. Devese destacar que se estabeleceu a alíquota de $1 \%$ para os metais nobres, para as pedras preciosas, para os carbonatos, entre outras substâncias minerais.

Tabela 19 - Distribuição dos recursos provenientes do IUM

\begin{tabular}{|c|c|}
\hline Esfera Administrativa de Governo & Cota-Parte do IUM \\
\hline União & $10 \%$ \\
\hline Estado & $70 \%$ \\
\hline Munićpio Produtor & $20 \%$ \\
\hline
\end{tabular}

Fonte: Lei Federal n. 4.425/64

Apesar da cota-parte municipal do IUM ser menor que a do CFEM, 20\% e $65 \%$, respectivamente, a considerável participação do IUM nas receitas de Pirapora do Bom Jesus demonstrava a importância do setor mineral para o município. Contudo, essa importância era acompanhada de distintos problemas de ordem técnica e ambiental.

Por outro lado, este setor é um dos principais geradores de empregos no município, tanto na atividade extrativa, como no 
beneficiamento de minérios, além de ser responsável por uma parcela significativa do Imposto Único sobre Minerais (IUM) na composição da receita municipal. (EMPLASA, 1982, p. 04).

$\mathrm{Na}$ época da elaboração do PDM de Pirapora do Bom Jesus, segundo o DNPM, 150 pessoas estavam ligadas diretamente ao setor extrativo mineral no município. Esse número referia-se somente às empresas que recolhiam o IUM. Porém, nesses dados não estavam computados os empregos relacionados ao beneficiamento ou às indústrias que utilizavam os insumos minerais produzidos no município (EMPLASA, 1982).

A prefeitura possuía um cadastro das indústrias que recolhiam uma taxa anual de licença de funcionamento para o município, que era fixada em função do número de empregados existentes. Segundo esse cadastro, trabalhavam com o beneficiamento de minério no município 30 empresas, que empregavam, aproximadamente, 250 pessoas (EMPLASA, 1982).

Pela análise desses dados, é possível verificar a importância do setor mineral no município de Pirapora do Bom Jesus, em meados da década de 1980. Esse setor era responsável pela absorção de, aproximadamente, $8 \%$ da população local. No entanto, o retorno financeiro do setor para o município não era proporcional, devido, principalmente, à clandestinidade da atividade.

A cota-parte do Imposto Único sobre Minerais (IUM) que retorna
atualmente ao município, não está correspondendo a real
dimensão da atividade mineral existente, embora sua participação
na composição da receita municipal seja, relativamente, uma das
maiores da RMSP. A queda contínua do IUM, a partir de 1978, e o
aumento das jazidas em atividade, leva a concluir que está
aumentando o número de extrações clandestinas. (EMPLASA,
1982, p. 18).

A Tabela 20 apresenta, entre outros dados, a participação do IUM na composição da receita de Pirapora do Bom Jesus. Esses resultados, juntamente com as interpretações do PDM de Pirapora do Bom Jesus, denotam que, no período de 1975 a 1980, ocorre a diminuição da participação do IUM no montante da receita municipal. A Tabela 20 também demonstra a variação anual das receitas municipais e do IUM. Assim, tornou-se possível analisar até que ponto houve uma diminuição real da arrecadação do IUM, pois a variação da arrecadação do IUM pode ser comparada com a variação da receita municipal.

O PDM de Pirapora do Bom Jesus atribuiu que a diminuição da arrecadação do IUM relacionava-se à fragilidade na fiscalização. Tal fato é amplamente aceitável, principalmente, diante do quadro da ilegalidade do 
setor. Entretanto, os dados também pressupõem que, em determinados períodos, o aumento da arrecadação do IUM ultrapassa 100\% e a receita municipal não acompanha esse percentual. Logo, em 1980, quando se registrou a menor participação do IUM na receita municipal, a receita municipal obteve maior variação (145,49\%). Deve-se também destacar que a participação do IUM na receita Municipal, em 1978, apresenta um valor que difere do descrito no PDM da RMSP (7,04\%), o que impõe certa cautela na utilização desses dados.

Tabela 20 - Participação do IUM (1975 a 1980) na composição da receita do município de Pirapora do Bom Jesus - SP

\begin{tabular}{|c|c|c|c|}
\hline Ano & $\begin{array}{c}\text { Variação da Receita Municipal } \\
\text { Referente ao Período Anterior }\end{array}$ & $\begin{array}{c}\text { Variação do IUM } \\
\text { Referente ao Período } \\
\text { Anterior }\end{array}$ & $\begin{array}{c}\text { Participação na } \\
\text { Reeita } \\
\text { Municipal }\end{array}$ \\
\hline 1975 & - & - & $4,07 \%$ \\
\hline 1976 & $26,97 \%$ & $115,16 \%$ & $6,90 \%$ \\
\hline 1977 & $37,15 \%$ & $26,48 \%$ & $6,36 \%$ \\
\hline 1978 & $50,37 \%$ & $165,17 \%$ & $11,22 \%$ \\
\hline 1979 & $113,12 \%$ & $-23,20 \%$ & $4,04 \%$ \\
\hline 1980 & $145,49 \%$ & $46,87 \%$ & $2,42 \%$ \\
\hline
\end{tabular}

Fonte: Balanços financeiros dos municípios (1975 a 1980) - in: EMPLASA (1982)

Os dados também demonstram que a cota-parte do imposto referente à atividade mineral, em Pirapora do Bom Jesus, gradativamente, diminuiu sua participação na composição da receita municipal. Contudo, a característica principal da mineração no município ainda era a irregularidade. O PDM de Pirapora do Bom Jesus diagnosticava que a exploração mineral ilegal presente no município relacionava-se aos problemas estruturais do setor, ou seja, tornava-se necessário uma ação conjunta por parte do poder público, além da definição plena das atribuições dos órgãos envolvidos.

A fragilidade da fiscalização, tanto por parte do DNPM como da prefeitura, facilita a instalação e exploração ilegal. Embora a Prefeitura Municipal tenha feito esforços no sentido de controlar com mais rigor a saída de substâncias minerais do município, este esforço não surtiu nenhum efeito, pois este órgão não dispõe de apoio legal para exercer fiscalização e portanto, autuar a atividade clandestina de mineração. Tal atribuição compete ao DNPM e à Receita Federal. Somente a prática de uma fiscalização sistemática pelos órgãos competentes e/ou uma maior autonomia municipal, que eventualmente Ihe venha ser outorgada através de convênios ou alterações legais, faria aumentar significativamente a 
arrecadação do IUM, refletindo assim o peso real que o setor mineral tem no município. (EMPLASA, 1982 p. 19 e 20).

O Cadastro Mineral do Sistema de Dados Essenciais sobre Atividade Mineral (PROSIG), que tinha a função de fornecer informações fundamentais sobre o quadro da exploração mineral, registrava 57 processos minerários existentes em Pirapora do Bom Jesus (16 requerimentos de pesquisa; 23 alvarás de pesquisa e 18 decretos de lavra). Constata-se que esse quadro era muito diferente do atual, inclusive com relação ao destino da produção, pois, no cadastro, não constava nenhum processo sobre regime de licenciamento de minerais de Classe II, de emprego imediato na construção civil (Lei Federal n. $6.567 / 78)$.

Segundo o PDM de Pirapora do Bom Jesus, a maior parte das substâncias existentes no município pertence à Classe VII, que se constituem de jazidas de minerais industriais, não incluídas nas Classes precedentes. Atualmente, é possível constatar que o perfil mineral do município, sobretudo, na Serra do Boturuna, inclui a exploração de minerais de Classe II.

A exploração mineral em Santana de Parnaíba na região da Serra do Boturuna não se comparava ao quadro existente em Pirapora do Bom Jesus. As poucas lavras existentes em Santana de Parnaíba na Serra localizavam-se na divisa com Pirapora do Bom Jesus e suas frentes se iniciavam nesse município. A situação dos produtos que mais contribuíam para a arrecadação do IUM em Santana de Parnaíba era, completamente, diferente da situação de Pirapora do Bom Jesus. "A atividade mineral que mais contribui para as arrecadações de IUM no município é a extração de brita, por apresentar maiores valores de produção e por ser esta atividade melhor controlada." (EMPLASA, 1985, p. 36). Porém, na ocasião da elaboração do PDM de Santana de Parnaíba, o município já estava em processo de diversificação de sua economia.

O IUM constituía uma parcela significativa da arrecadação tributária de Santana de Parnaíba, na década de 1970. Segundo o PDM da RMSP, em 1978, o IUM representou $12,05 \%$ da receita do município, que possuía oito áreas de extração mineral (EMPLASA, 1981). Ao considerar a mesma cotaparte do CFEM (65\%), o IUM participaria em, aproximadamente, $40 \%$ da receita do município. Porém, a arrecadação do IUM não era maior em virtude 
do pequeno volume de minério extraído, do seu baixo valor comercial e das diversas explorações ilegais.

\subsubsection{Representatividade atual do CFEM na composição das receitas municipais}

A situação atual da participação do CFEM na composição da receita total do município de Pirapora Bom Jesus demonstra que o setor minerário não possui a mesma contribuição que a verificada na década de 1970 e em meados da década de 1980. Convém destacar, mais uma vez, que nesse período, a cota-parte do IUM para os municípios era somente de $20 \%$, diferente do atual CFEM que apresenta cota-parte municipal de 65\%. Dessa forma, os dados demonstram que o setor mineral contribui, cada vez menos, na composição das receitas de Pirapora do Bom Jesus, com participações inferiores a $1 \%$ (Tabela 21).

Por meio da análise da Tabela 22, observou-se essa característica também para o município de Santana de Parnaíba. No entanto, torna-se necessário enfatizar que esse município possui economia muito diversificada e a mineração, atualmente, não se constitui num setor importante para o município, apesar da intensa exploração na Serra do Itaqui.

Os dados também demonstram certa irregularidade nos valores de recolhimento do imposto. Essa característica pode se relacionar à demanda de produção ou às inconsistências dos dados.

Tabela 21 - Participação do CFEM na composição da receita do município de Pirapora do Bom Jesus - SP (1999 a 2005)

\begin{tabular}{|c|c|c|c|}
\hline Ano & $\begin{array}{c}\text { Variação da Receita } \\
\text { Municipal Referente } \\
\text { ao Período Anterior }\end{array}$ & $\begin{array}{c}\text { Variação do } \\
\text { CFEM Referente } \\
\text { ao Período } \\
\text { Anterior }\end{array}$ & $\begin{array}{c}\text { Participação do CFEM na Receita do } \\
\text { Município }\end{array}$ \\
\hline 1999 & & & $0,14 \%$ \\
\hline 2000 & $5,14 \%$ & $15,89 \%$ & $0,16 \%$ \\
\hline 2001 & $66,82 \%$ & $-17,02 \%$ & $0,08 \%$ \\
\hline 2002 & $45,44 \%$ & $36,02 \%$ & $0,07 \%$ \\
\hline 2003 & $-3,94 \%$ & $175,74 \%$ & $0,21 \%$ \\
\hline 2004 & $22,93 \%$ & $-16,20 \%$ & $0,14 \%$ \\
\hline 2005 & $19,01 \%$ & $-16,47 \%$ & $0,10 \%$ \\
\hline
\end{tabular}

Fonte: DNPM - <www.dnpm.gov.br>. Acesso em: 2008 
Tabela 22 - Participação do CFEM na composição da receita do município de Santana de Parnaíba - SP (1999 a 2005)

\begin{tabular}{|c|c|c|c|}
\hline Ano & $\begin{array}{c}\text { Variação da } \\
\text { Receita Municipal } \\
\text { Referente ao } \\
\text { Período Anterior }\end{array}$ & $\begin{array}{c}\text { Variação do } \\
\text { CFEM Referente } \\
\text { ao Período } \\
\text { Anterior }\end{array}$ & $\begin{array}{c}\text { Participação do CFEM na Receita do } \\
\text { Município }\end{array}$ \\
\hline 1999 & & & $0,09 \%$ \\
\hline 2000 & $22,72 \%$ & $-29,07 \%$ & $0,05 \%$ \\
\hline 2001 & $24,49 \%$ & $-13,04 \%$ & $0,04 \%$ \\
\hline 2002 & $28,88 \%$ & $-16,06 \%$ & $0,02 \%$ \\
\hline 2003 & $29,43 \%$ & $16,41 \%$ & $0,02 \%$ \\
\hline 2004 & $27,79 \%$ & $20,65 \%$ & $0,02 \%$ \\
\hline 2005 & $15,95 \%$ & $1,34 \%$ & $0,02 \%$ \\
\hline
\end{tabular}

Fonte: DNPM - <www.dnpm.gov.br>. Acesso em: 2008

\section{TERRITÓRIO E POLÍTICA AMBIENTAL}

A preservação e a conservação de espaços naturais são regulamentadas por distintos instrumentos jurídicos, determinados, muitas vezes, pela legislação ambiental. Tal legislação torna-se política ambiental que atua na organização do território e impõe determinadas restrições e diretrizes de ocupação.

$\mathrm{Na}$ ciência geográfica, o conceito de território possui relação entre o espaço e o poder, assim, o território pode ser definido como um espaço de atuação de um determinado poder. Essa componente política, juntamente com os aspectos naturais, culturais, sociais e econômicos, define esse espaço e sua territorialidade. O território torna-se objeto de ação política que, muitas vezes, ocorre em espaços diferenciados.

Uma política pública ambiental permite elaborar formas de preservar determinadas porções do espaço, o que a difere de uma política territorial, cujo objetivo é reestruturar o território de acordo como o modelo econômico atuante. Nesse caso, o território torna-se objeto de reprodução do modelo econômico.

A exploração territorial em busca de recursos naturais fez com que espaços naturais se convertessem em espaços antrópicos. Deve-se destacar nessa alteração a quebra do equilíbrio do ambiental, que fora descrita na proposta metodológica desta pesquisa.

O crescimento urbano e agrícola é acompanhado pela diminuição de biodiversidade de ambientes naturais. Esse crescimento é, sobretudo, 
conseqüência da inovação tecnológica e do aumento da produção e exploração dos recursos naturais. Logo, a concentração urbana veio acompanhada do alto consumo de matérias-primas e de energia. $O$ custo ambiental dessa essência começou a ser colocado em questão, o que criou um aparato de proteção à natureza por meio medidas de controle ambiental e da criação de espaços naturais protegidos.

Além dos aspectos jurídicos relacionados à legislação ambiental, a preservação de espaços naturais, de certa forma, também depende de políticas tributárias. Políticas que, mormente, estão relacionadas à compensação financeira aos municípios que possuem determinada unidade de conservação, que se caracteriza como um mecanismo econômico para garantir a preservação.

A criação de espaços naturais protegidos faz com que os municípios possuam certas restrições à utilização de determinados espaços de seus territórios. No entanto, na lógica da produção, esses espaços podem se tornar ônus econômico, pois, dependendo da tipologia de proteção, não há possibilidade para a exploração de seus recursos naturais.

Uma política pública de proteção ambiental pode assim gerar um problema social e econômico. Há, assim, uma interface entre as políticas territoriais e ambientais. Por isso, optou-se por compensar as perdas produtivas econômicas que tal política exerce sobre o território por meio de um aparato jurídico tributário compensatório.

Dentro dos ramos do direito que deverão estar engajados nessa nova filosofia, o direito tributário tem certamente importância vital, devendo a tributação ambiental ser utilizada como instrumento eficaz, tanto para canalizar recursos para a prestação de serviços públicos ambientais, como para induzir comportamentos não degradadores. (SÃO PAULO, 1998, p. 13).

O estabelecimento de uma política ambiental e sua componente compensatória torna-se um dos fundamentos mais importantes da ação pública para manter o equilíbrio ecológico. Nesse sentido, o governo canaliza recursos providos da tributação fiscal e aplicados numa política ambiental. A tributação torna-se um instrumento de combate à degradação ambiental e estímulo à preservação ambiental. Entre os instrumentos econômicos e financeiros para a garantia do equilíbrio ecológico estão os sistemas de alíquotas, de isenções e 
de restituições utilizados em processos produtivos não poluidores ou como estímulo à preservação de áreas naturais.

Com relação à preservação e gestão ambiental, destacam-se três mecanismos tributários: a tributação diferenciada, que atua como um mecanismo de estímulo aos processos produtivos não poluidores, os mecanismos de compensação financeira, relacionados à limitação do uso e ocupação do solo, e os impostos ambientais, sendo aplicados ao uso de determinado recurso natural, por exemplo, a água. Nesse mecanismo, a tributação passa a ser um mecanismo controlador atuante na gestão ambiental dos recursos.

No Estado de São Paulo, uma das principais leis que prevêem compensação financeira aos municípios em função das limitações impostas pela necessidade de proteção ambiental é a Lei Estadual n. 8.510/93, denominada ICMS ecológico.

\subsection{LEI ESTADUAL N. 8.510/93 - ICMS ECOLÓGICO}

O Imposto sobre Circulação de Mercadorias e Serviços (ICMS) constituise num dos principais tributos Estaduais. A Constituição Federal prescreve no art. 158 , inciso IV que $25 \%$ do produto da arrecadação desse imposto devem ser repassados aos municípios. A Lei Complementar n. 63/90, entre outras disposições, define os critérios de transferência desses recursos.

Conforme 0 art. $3^{\circ}$., inciso I, efetua-se a distribuição desse recurso financeiro segundo o Valor Adicionado Fiscal (VAF), que estabelece que três quartos, no mínimo, do repasse são relativos à participação do município na geração dessa receita para o Estado, ou seja, a transferência de 75\% da cota ICMS que pertence aos municípios é distribuída de acordo com as operações relativas à circulação de mercadorias e prestação de serviço realizado dentro do município.

É a diferença positiva entre o valor das saídas de mercadorias e das prestações de serviços, por alienação, e o valor das entradas de mercadorias e das prestações de serviço, por aquisições. $O$ valor adicionado de cada município paulista é a soma dos valores adicionados ocorridos nos estabelecimentos inscritos no respectivo território. (SÃO PAULO, 1998 p. 40). 
$\mathrm{O}$ art. $3^{\circ}$., inciso II, prescreve que até um quarto é repassado de acordo com os critérios definidos pelo Estado. Dessa forma, a Lei Estadual $\mathrm{n}$. 3.201/81, com redação dada pela Lei Estadual n. 8.510/93, determina que o valor de participação dos municípios, segundo o VAF seja de $76 \%$. Entretanto, $24 \%$ são distribuídos segundo os critérios relacionados ao percentual entre a população de cada município e a população do Estado, à relação tributária entre os municípios, à área cultivada do município em relação à área total cultivada no Estado, às áreas de reservatórios de água inseridas no município, aos espaços territoriais especialmente protegidos, entre outros.

Até a redação da Lei Estadual n. 8.510/93, o valor do VAF era de $80 \%$. No entanto, com o intuito de incentivar algumas políticas territoriais, esse valor foi reduzido para $76 \%$ e inseridos alguns critérios para a distribuição da cotaparte do ICMS aos municípios, entre os quais, a presença de espaços territoriais especialmente protegidos, descritos no inciso VI da lei. Esse inciso dispõe que $0,5 \%$ da cota-parte distribuem-se para os municípios que possuem espaços territoriais especialmente protegidos. Definiu-se essa política tributária como ICMS ecológico, pois possui o objetivo de manter a qualidade ambiental desses espaços. A Tabela 23 apresenta os percentuais de repasse de ICMS, segundo a legislação sobre a matéria.

Tabela 23 - Percentuais de repasse de ICMS conforme Lei Estadual $n$. $8.510 / 93$

\begin{tabular}{|c|c|}
\hline Componente & Porcentagem \\
\hline Valor adicionado & $76 \%$ \\
\hline População & $13 \%$ \\
\hline Receita tributária própria & $5 \%$ \\
\hline Área cultivada & $3 \%$ \\
\hline Componente percentual fixo & $2 \%$ \\
\hline Espaços territoriais especialmente protegidos & $0,5 \%$ \\
\hline $\begin{array}{c}\text { Reservatórios de água destinados à geração } \\
\text { de energia elétrica }\end{array}$ & $0,5 \%$ \\
\hline
\end{tabular}

A Lei Estadual n. 9.509/97, que dispõe sobre a Política Estadual de Meio Ambiente, define no art. $3^{\circ}$., inciso $\mathrm{VI}$, o conceito de Espaços Territoriais Especialmente Protegidos como: "[...] áreas que por força da legislação sofrem restrição de uso, como Unidades de Conservação, Áreas Naturais Tombadas, Áreas de Proteção aos Mananciais, e outras previstas na legislação pertinente;" 
O critério que definiu tais espaços para efeito de ICMS ecológico não inclui as Áreas de Proteção aos Mananciais. Porém, estipulou-se o percentual de $0,5 \%$ para os municípios que possuem reservatórios de água para a geração de energia elétrica. O repasse resulta da relação entre a área alagada no município e a soma das áreas alagadas de todos os municípios do Estado. A Lei Estadual n. 9.332/95 deu nova conceituação para esse critério, incluindo reservatório, barragem e suas comportas, vertedouros, condutos forçados, casa de máquinas e subestações elevatórias.

A Lei Estadual n. 8.510/95 disciplina a distribuição desse percentual entre os municípios por meio do critério de ponderação, sendo estipulado pesos aos distintos tipos de unidades de conservação, segundo a Tabela 24.

Tabela 24 - Índices de ponderação conforme Lei Estadual n. 8.510/95

\begin{tabular}{|c|c|}
\hline Espaço Territorial Especialmente Protegido & Peso \\
\hline Estações Ecológicas & 1,0 \\
\hline Reservas Biológicas & 1,0 \\
\hline Parques Estaduais & 0,8 \\
\hline Zonas de Vida Silvestre (ZVS) em APA & 0,5 \\
\hline Reservas Florestais & 0,2 \\
\hline Áreas de Proteção Ambiental (APAs) & 0,1 \\
\hline Áreas Naturais Tombadas & 0,1 \\
\hline
\end{tabular}

De acordo com a Secretária Estadual do Meio Ambiente (SÃO PAULO, 1998), o critério para a definição do índice de participação dos municípios considera:

Área total em hectares, considerando o espaço territorial especialmente protegido no município;

- Percentual da área sob proteção legal do Estado em relação à área territorial do município;

- VAF do município;

- O inverso da receita municipal per capita - composta pela somatória dos recursos, divididos pela população do município.

O estabelecimento dos espaços territoriais especialmente protegidos implica em regulamentos e normas que interferem direta ou indiretamente no uso e na ocupação destes territórios, com restrições diferenciadas em função dos atributos protegidos, que, por sua vez, podem refletir na administração municipal sob a forma de redução na arrecadação de tributos, especialmente nos municípios sobre os quais incidem grandes áreas de unidades de conservação e têm pequena receita, para os quais a compensação financeira 
deverá representar um acréscimo significativo. (SÃO PAULO, 1998, p. 25).

É possível considerar o ICMS ecológico como uma política pública para preservação ambiental, pois seu princípio está na regulação não coercitiva por meio da compensação financeira de acordo com a preservação ambiental de determinada porção do território, ou seja, utiliza-se o princípio protetorrecebedor. No entanto, essa política tributária também pode ser interpretada, em relação à preservação ambiental, como um instrumento financeiro compensatório, justificado pelo próprio índice de ponderação no qual se baseia no fator de restrição ao uso e ocupação do solo.

Apesar desse importante avanço na legislação tributária ambiental, o critério para o repasse de recursos com base os espaços territoriais especialmente protegidos considera somente o aspecto quantitativo das áreas protegidas, ou seja, a relação entre as áreas de preservação existentes no município e o total de áreas de preservação no Estado. $O$ aspecto qualitativo dos espaços naturais não é considerado, ou seja, a legislação não determina o índice para o repasse de verba conforme o grau de conservação do espaço.

O ICMS Ecológico no Estado de São Paulo não tem caráter indutor, à medida em que a melhoria da qualidade ambiental não é tomada como critério de distribuição da cota-parte do ICMS destinada aos Municípios. O repasse referente ao critério Espaços Territoriais Especialmente Protegidos tem sido realizado considerando-se a relação entre os Espaços Territoriais Especialmente Protegidos no Município e a soma de todas as áreas no Estado. (SÃO PAULO, 1998, p. 41).

Deve-se aperfeiçoar essa legislação de forma a definir alguns padrões de manutenção e a melhoria da qualidade ambiental nas unidades de conservação. Nesse sentido, o ICMS ecológico não deve ser pautado apenas na compensação financeira e seu percentual de repasse também poderia ser condicionado aos parâmetros de qualidade dos espaços territoriais protegidos, o que o tornaria também um instrumento de gestão ambiental.

Outra questão importante está relacionada às unidades de conservação estabelecidas pelos municípios. Essas unidades não condicionam o repasse de verba da cota do ICMS ecológico. Assim, muitas vezes, isso não estimula uma política de proteção de espaços naturais por parte dos municípios. 


\subsubsection{Análise Comparativa Entre a ANT e a APA}

De acordo com a Lei Estadual n. 8.510/93, as ANTs e as APAs possuem os mesmos índices de ponderação para o repasse dos recursos proveniente do ICMS ecológico, ou seja, 0,1\%. Tal aspecto supõe que essas tipologias de proteção possuam o mesmo grau de restrição ao uso e ocupação do solo. Entretanto, a APA possui tipos genéricos de limitações, o que pressupõe um ZEE e uma Zona de Vida Silvestre (ZVS). O ZEE remete a APA à fiscalização e às limitações das propriedades públicas e privadas inseridas em seu perímetro para isso definem-se as áreas onde se permitem a exploração dos recursos naturais. Por meio desse controle, teoricamente, a punição estabelecida nessa categoria de proteção, torna-se mais rigorosa do que numa ANT. Já o tombamento não possui a necessidade de um zoneamento e de procedimentos de gestão do espaço natural. As restrições de uso e de ocupação fazem parte das leis que regem a matéria, o que inclui a própria resolução de tombamento, logo, não se prescrevem áreas específicas de proteção. No âmbito de uma ANT, a licença para construir constitui-se numa autorização para construir, modificar e alterar a área ou imóvel. O termo licença pode predispor o estabelecimento de critérios pré-ordenados, diferente do termo autorização.

No caso dos monumentos naturais, o proprietário deve pedir autorização para plantar espécies vegetais, para arrancar ou colher vegetais ou capturar animais, ou alterar o local (isto é, para fazer aterros, escavações, canais, construir ou modificar construções existentes). (MACHADO, 2004, p. 910).

Outra importante observação refere-se aos atributos de proteção: a criação de uma APA não está relacionada à excepcionalidade dos valores a proteger, assim, a proteção da área tem o intuito de garantir o equilíbrio ecológico local.

Sublinhe-se que a APA (Área de Proteção Ambiental), consoante sua estrutura legal, não exige nenhuma obra de conservação ou de reparação como encargo público, como subsidiariamente ocorre no tombamento. Dessa forma a APA é menos onerosa para o Poder público. (MACHADO, 2004, p. 908).

Uma característica interessante relacionada ao tombamento refere-se à ação do cidadão na fiscalização sobre a conservação do bem tombado. Logo, "O cidadão pode pleitear perante o Judiciário a anulação do ato lesivo ao patrimônio histórico, artístico e natural [...]" (MACHADO, 2004, p. 926). 
O tombamento de áreas naturais faz com que esses espaços naturais possuam, muitas vezes, instrumentos de preservação contraditórios, em virtude da existência de uma legislação ambiental ampla que inclui instrumentos de proteção e de conservação com maior aplicabilidade.

$O$ ato de tombamento se constitui no principal instrumento de preservação do patrimônio histórico e cultural. No entanto, com relação ao patrimônio natural, sua abrangência é limitada. A própria legislação de tombamento destaca, de forma majoritária, as formas de intervenção e de manutenção do bem tombado em edificações, ou seja, não se desenvolveu um controle jurídico amplo para áreas naturais tombadas.

Com o desenvolvimento da legislação ambiental e das instituições públicas voltadas para a criação e para a manutenção de unidades de conservação, o ato de tombamento de áreas naturais perdeu um pouco da sua importância, também contribuiu para isso, a não inclusão dessa categoria de proteção no SNUC. Apesar desses aspectos, o princípio que envolve o estabelecimento de uma ANT faz com que esse instrumento jurídico para a preservação possua importância fundamental, em função de seu principal atributo de proteção: as paisagens naturais.

\subsubsection{Representatividade do ICMS ecológico na composição das receitas municipais}

O estabelecimento desse instrumento jurídico ambiental permite que os municípios adquiram um acréscimo nas receitas do ICMS por possuírem espaços naturais protegidos em seus territórios. Com relação à Pirapora do Bom Jesus, a Tabela 25 demonstra uma baixa participação desse componente na receita municipal. Entretanto, ao considerar a participação do ICMS ecológico na composição do ICMS, a situação, de certa forma, é favorável. 
Tabela 25 - Participação do ICMS ecológico na composição da receita do município de Pirapora do Bom Jesus - SP (1999 a 2005)

\begin{tabular}{|c|c|c|c|}
\hline Ano & $\begin{array}{c}\text { Participação do } \\
\text { ICMS Ecológico } \\
\text { na Composição } \\
\text { do ICMS }\end{array}$ & $\begin{array}{c}\text { Variação do } \\
\text { ICMS Ecológico } \\
\text { Referente ao } \\
\text { Período Anterior }\end{array}$ & $\begin{array}{c}\text { Participação do ICMS Ecológico na Receita } \\
\text { do Município }\end{array}$ \\
\hline 1999 & $2,61 \%$ & & $0,48 \%$ \\
\hline 2000 & $2,30 \%$ & $35,59 \%$ & $0,61 \%$ \\
\hline 2001 & $1,57 \%$ & $0,63 \%$ & $0,37 \%$ \\
\hline 2002 & $1,55 \%$ & $21,39 \%$ & $0,31 \%$ \\
\hline 2003 & $1,72 \%$ & $6,29 \%$ & $0,34 \%$ \\
\hline 2004 & $1,48 \%$ & $-6,70 \%$ & $0,26 \%$ \\
\hline 2005 & $1,51 \%$ & $11,55 \%$ & $0,24 \%$ \\
\hline
\end{tabular}

Fonte: SÃO PAULO (2007); Secretaria de Estado dos Negócios da Fazenda de São Paulo - <www.fazenda.sp.gov.br>. Acesso em: 2008; Secretaria do Tesouro Nacional/Ministério da Fazenda $-<w w w . t e s o u r o . g o v . b r>$. Acesso em 2007.

Para Santana de Parnaíba, os dados da Tabela 26 descrevem uma participação ainda menor do ICMS ecológico na receita municipal, se comparado ao município de Pirapora do Bom Jesus. Além de possuir, em seu território poucos espaços naturais protegidos, há relevância de outros fatores na composição do ICMS do município. Deve-se destacar que o município apresenta importante setor industrial e de serviços.

Tabela 26 - Participação do ICMS ecológico na composição da receita do município de Santana de Parnaíba - SP (1999 a 2005)

\begin{tabular}{|c|c|c|c|}
\hline Ano & $\begin{array}{c}\text { Participação do } \\
\text { ICMS Ecológico } \\
\text { na Composição } \\
\text { do ICMS }\end{array}$ & $\begin{array}{c}\text { Variação do } \\
\text { ICMS Ecológico } \\
\text { Referente ao } \\
\text { Período Anterior }\end{array}$ & $\begin{array}{c}\text { Participação do ICMS Ecológico na } \\
\text { Receita do Município }\end{array}$ \\
\hline 1999 & $0,27 \%$ & & $0,03 \%$ \\
\hline 2000 & $0,16 \%$ & $-5,67 \%$ & $0,03 \%$ \\
\hline 2001 & $0,15 \%$ & $18,79 \%$ & $0,02 \%$ \\
\hline 2002 & $0,16 \%$ & $28,58 \%$ & $0,02 \%$ \\
\hline 2003 & $0,15 \%$ & $7,21 \%$ & $0,02 \%$ \\
\hline 2004 & $0,15 \%$ & $8,94 \%$ & $0,02 \%$ \\
\hline 2005 & $0,11 \%$ & $-15,06 \%$ & $0,01 \%$ \\
\hline
\end{tabular}

Fonte: SÃO PAULO (2007); Secretaria de Estado dos Negócios da Fazenda de São Paulo - <www.fazenda.sp.gov.br>. Acesso em: 2008; Secretaria do Tesouro Nacional/Ministério da Fazenda - <www.tesouro.gov.br>. Acesso em 2007. 


\subsection{COMPARAÇÃO ENTRE ICMS ECOLÓGICO E A CFEM}

A demonstração da participação na receita municipal do CFEM e do ICMS ecológico tem o objetivo de ponderar qual dos componentes é mais significativo para os municípios. Apesar das diferentes realidades econômicas, esses dados permitem avaliar e a importância econômica da preservação de áreas naturais ou do desenvolvimento da atividade mineral nos municípios de Pirapora do Bom Jesus e Santana de Parnaíba.

O Gráfico 5 descreve que, em Pirapora do Bom Jesus, o ICMS ecológico é mais significativo do que a CFEM. No entanto, com relação à Santana de Parnaíba, o Gráfico 6 demonstra que o quadro se inverte.

Gráfico 5 - Evolução da participação do CFEM e do ICMS ecológico na composição da receita de Pirapora do Bom Jesus - SP (1999 a 2005)

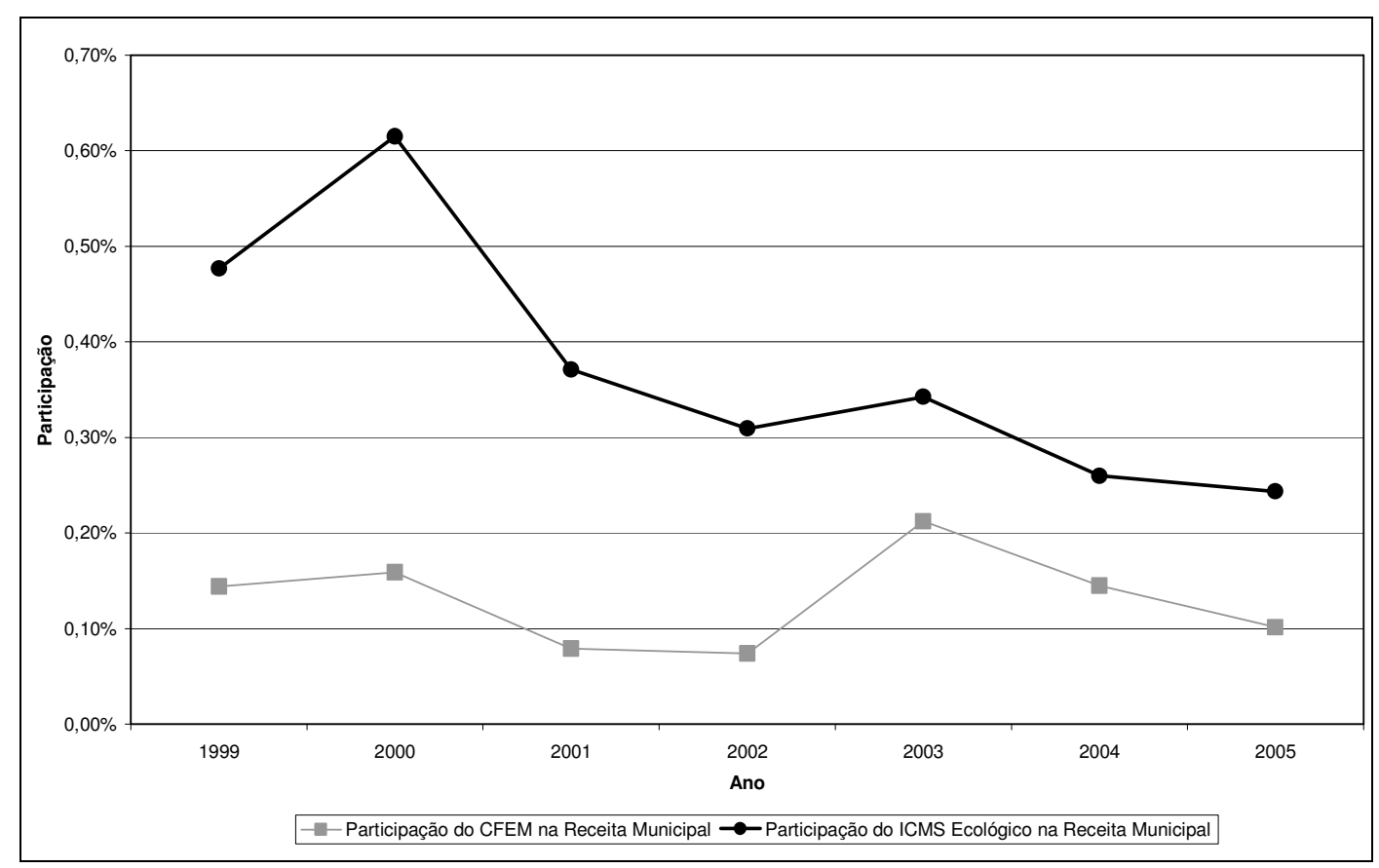

Os Gráficos também demonstram certa correlação entre o aumento ou diminuição dos componentes na participação da receita municipal. Assim, observa-se que, se há aumento da participação do ICMS ecológico num determinado ano, ocorre um aumento da participação da CFEM. 
Gráfico 6 - Evolução da participação do CFEM e do ICMS ecológico na composição da receita de Santana de Parnaíba - SP (1999 a 2005)

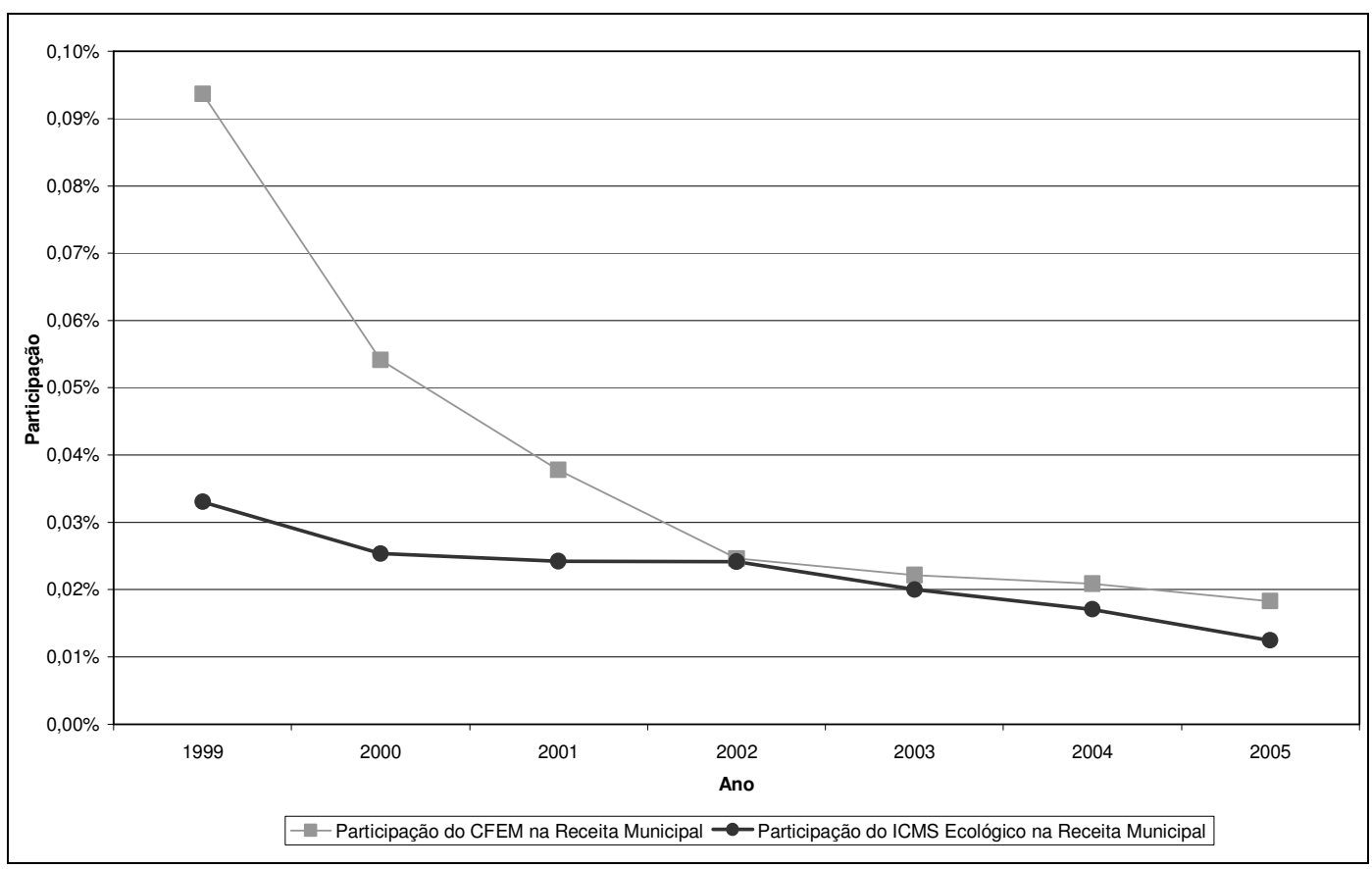

\section{QUADRO ATUAL DA MINERAÇÃO EM PIRAPORA DO BOM JESUS E SANTANA DE PARNAÍBA}

Analisou-se o quadro atual da mineração em Pirapora do Bom Jesus e Santana de Parnaíba por meio das poligonais minerárias cadastradas no Sistema de Gestão da Produção Mineral (SISMINE) do DNPM.

Os dados da Tabela 27 descrevem a quantidade de poligonais cadastradas por fases da exploração mineral. Pirapora do Bom Jesus possui 29 poligonais cadastradas em seu território. No entanto, deve-se ater a fase de concessão de lavra, onde há 17 poligonais. Destaca-se também que sete poligonais sob o regime de concessão de lavra estão na região da ANT da Serra do Boturuna. Em Santana de Parnaíba, num total de 28 poligonais, 20 desses setores estão na fase de concessão de lavra, ou seja, na teoria, essas poligonais possuem produção comercializada. 
Tabela 27 - Poligonais minerárias dos municípios de Pirapora do Bom Jesus e Santana de Parnaíba, Estado de São Paulo

\begin{tabular}{|l|c|c|}
\hline \multirow{2}{*}{\multicolumn{1}{|c|}{ Fase }} & \multicolumn{2}{c|}{ Quantidade de Poligonais Minerárias } \\
\cline { 2 - 3 } & Pirapora do Bom Jesus & Santana de Parnaíba \\
\hline Disponibilidade de Pesquisa Mineral & 3 & 2 \\
\hline Requerimento de Pesquisa & 2 & 2 \\
\hline Autorização de Pesquisa & 4 & 4 \\
\hline Requerimento de Lavra & 3 & 1 \\
\hline Concessão de Lavra & 17 & 20 \\
\hline
\end{tabular}

Fonte: DNPM/SISMINE - <www.dnpm.gov.br>. Acesso em: 2008.

Convém ressaltar que muitas dessas poligonais abrangem dois municípios. Por isso, foi conveniente apresentar a Tabela 28 que expõe as fases de mineração e se a poligonal possui limite em outro município ou abrange somente um único município. Se a poligonal envolver mais de um município, a ordem de descrição corresponde à proporção da poligonal no município.

Tabela 28 - Abrangência das poligonais minerárias

\begin{tabular}{|c|l|c|}
\hline \multicolumn{1}{|c|}{ Fase } & \multicolumn{1}{|c|}{ Localização } & Quantidade \\
\hline \multirow{4}{*}{ Disponibilidade de Pesquisa Mineral } & Limite Cajamar/Santana de Parnaíba & 1 \\
\cline { 2 - 3 } & Limite Santana de Parnaíba/Pirapora do & 1 \\
& Bom Jesus & 3 \\
\cline { 2 - 3 } Requerimento de Pesquisa & Pirapora do Bom Jesus & 1 \\
\hline \multirow{5}{*}{ Autorização de Pesquisa } & Limite Cajamar/Santana de Parnaíba & 1 \\
\cline { 2 - 3 } & Limite Santana de Parnaíba/Cajamar & 2 \\
\cline { 2 - 3 } & Pirapora do Bom Jesus & 1 \\
\hline \multirow{5}{*}{ Requerimento de Lavra } & Limite Barueri/Santana de Parnaíba & 1 \\
\cline { 2 - 3 } & $\begin{array}{l}\text { Limite Pirapora do Bom } \\
\text { Jesus/Araçariguama }\end{array}$ & 2 \\
\cline { 2 - 3 } & Limite Pirapora do Bom Jesus/Cajamar & 1 \\
\cline { 2 - 3 } & Pirapora do Bom Jesus & 1 \\
\cline { 2 - 3 } & Santana de Parnaíba & 2 \\
\hline & Limite Pirapora do Bom Jesus/Cajamar & 1 \\
\cline { 2 - 3 } & Limite Santana de Parnaíba/Barueri & 1 \\
\cline { 2 - 3 } Concessão de Lavra & Pirapora do Bom Jesus & 9 \\
\hline & Limite Barueri/Santana de Parnaíba & 16 \\
\cline { 2 - 3 } & Limite Pirapora do Bom Jesus/Santana \\
& de Parnaíba & 1 \\
\cline { 2 - 3 } & Limite Santana de Parnaíba/Barueri & 4 \\
\cline { 2 - 3 } & Pirapora do Bom Jesus & 1 \\
\cline { 2 - 3 } & Santana de Parnaíba & 1 \\
\hline
\end{tabular}

Fonte: DNPM/SISMINE - <www.dnpm.gov.br>. Acesso em: 2008. 
Deve-se observar que, muitas vezes, numa área com potencial mineral para determinada substância, há diversas poligonais cadastradas para o mesmo requerente. Tal exemplo ocorre, principalmente, em Santana de Parnaíba, na exploração do Batólito Granítico do Itaqui. Nessa região, de acordo com a Tabela 29, verificou-se 13 poligonais de concessão de lavra, porém, grande parte dessas poligonais corresponde à mesma mineradora.

Tabela 29 - Substância mineral e fase do processo minerário

\begin{tabular}{|c|c|c|c|c|}
\hline Substância & Fase & Pirapora do Bom Jesus & Santana de Parnaíba & Total \\
\hline Areia & Concessão de Lavra & - & 2 & 2 \\
\hline \multirow{2}{*}{ Argila } & $\begin{array}{c}\text { Requerimiento de } \\
\text { Lavra }\end{array}$ & - & 1 & 1 \\
\hline & Concessão de Lavra & 1 & - & 1 \\
\hline Arsênio & $\begin{array}{c}\text { Requerimento de } \\
\text { Pesquisa }\end{array}$ & - & 1 & 1 \\
\hline \multirow{3}{*}{ Calcário } & $\begin{array}{l}\text { Autorização de } \\
\text { Pesquisa }\end{array}$ & 1 & - & 1 \\
\hline & $\begin{array}{c}\text { Requerimiento de } \\
\text { Lavra }\end{array}$ & 1 & - & 1 \\
\hline & Concessão de Lavra & 3 & - & 3 \\
\hline $\begin{array}{l}\text { Calcário } \\
\text { Dolomítico }\end{array}$ & Concessão de Lavra & 1 & - & 1 \\
\hline Caulim & Concessão de Lavra & 1 & - & 1 \\
\hline \multirow{3}{*}{ Dolomito } & Disponibilidade & - & 1 & 1 \\
\hline & $\begin{array}{c}\text { Requerimento de } \\
\text { Pesquisa }\end{array}$ & - & 1 & 1 \\
\hline & Concessão de Lavra & 1 & 3 & 4 \\
\hline Feldspato & Concessão de Lavra & - & 1 & 1 \\
\hline Ferro & Concessão de Lavra & 1 & - & 1 \\
\hline \multirow{5}{*}{ Filito } & Disponibilidade & 3 & - & 3 \\
\hline & $\begin{array}{l}\text { Requerimento de } \\
\text { Pesquisa }\end{array}$ & 2 & - & 2 \\
\hline & $\begin{array}{l}\text { Autorização de } \\
\text { Pesquisa }\end{array}$ & 2 & 1 & 3 \\
\hline & $\begin{array}{c}\text { Requerimiento de } \\
\text { Lavra }\end{array}$ & 2 & - & 2 \\
\hline & Concessão de Lavra & 4 & 1 & 5 \\
\hline \multirow{2}{*}{ Granito } & $\begin{array}{l}\text { Autorização de } \\
\text { Pesquisa }\end{array}$ & - & 1 & 1 \\
\hline & Concessão de Lavra & - & 13 & 13 \\
\hline Hematita & Concessão de Lavra & 1 & - & 1 \\
\hline \multirow{3}{*}{ Leucofilito } & Disponibilidade & - & 1 & 1 \\
\hline & $\begin{array}{c}\text { Autorização de } \\
\text { Pesquisa } \\
\end{array}$ & - & 1 & 1 \\
\hline & Concessão de Lavra & 1 & - & 1 \\
\hline \multirow[t]{2}{*}{ Quartzito } & $\begin{array}{c}\text { Autorização de } \\
\text { Pesquisa }\end{array}$ & 1 & 1 & 2 \\
\hline & Concessão de Lavra & 2 & - & 2 \\
\hline Xisto Argiloso & Concessão de Lavra & 1 & - & 1 \\
\hline
\end{tabular}

Fonte: DNPM/SISMINE - <www.dnpm.gov.br>. Acesso em: 2008. 
Outra observação importante refere-se à explotação das substâncias: nem sempre a concessão da lavra corresponde à lavra em atividade. Na Serra do Boturuna, por exemplo, há três áreas com poligonais sob o regime de concessão de lavra, onde não se executam as lavras.

De forma simplificada, os dados sobre a concessão de lavra, descritos na Tabela 29, ajudam a descrever o perfil mineral dos municípios. O Mapa 12 apresenta a distribuição das lavras sob regime de concessão nos municípios. Em Pirapora do Bom Jesus essas lavras se concentram na região da Serra do Boturuna e nas proximidades com Santana de Parnaíba. Nesse município, as principais substâncias exploradas são os quartzitos (metarenitos), os calcários (calcário dolomítico e dolomito) e os filitos. Em Santana de Parnaíba, as poligonais minerárias na fase de concessão localizam-se, especialmente, no setor meridional do município, no Batólito Granítico do Itaqui. Essa área possui alto potencial para a consecução de brita. A exploração do granito do Itaqui destaca-se como uma das principais áreas da RMSP de extração de brita.

Convém destacar que o cadastro do SISMINE menciona apenas a substância principal, logo, numa lavra, normalmente, há a exploração de outras substâncias, denominadas subprodutos, característica que ocorre nas explorações da Serra do Boturuna. Com relação às mineradoras e às substâncias principais exploradas nos municípios, os dados da Tabela 30 ajudam a caracterizar a situação mineral. Observa-se a participação de grandes grupos, principalmente, na exploração do granito no Itaqui, entre as quais, a Camargo Corrêa Cimentos S. A. e a Construtora Constran por meio da Polimix Concreto Ltda. Destaca-se também a exploração de calcário em Pirapora do Bom Jesus pela Companhia Siderúrgica Paulista (COSIPA). 
Tabela 30 - Concessão de lavra nos municípios de Pirapora do Bom Jesus e Santana de Parnaíba, Estado de São Paulo

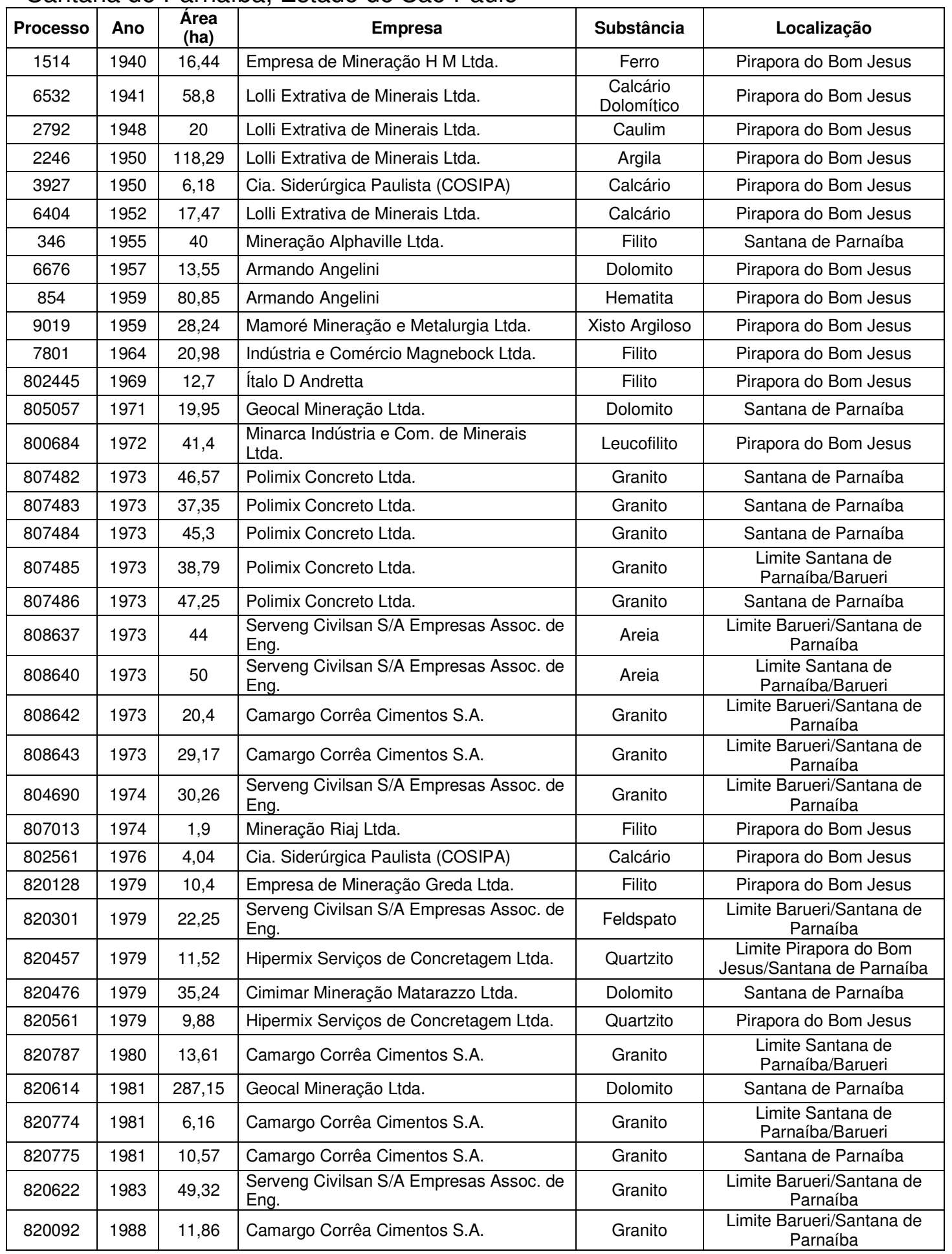

Fonte: DNPM/SISMINE - <www.dnpm.gov.br>. Acesso em: 2008. 


\subsection{MINERAÇÃO NA SERRA DO BOTURUNA}

Com relação à litoestrutura, a região da ANT da Serra do Boturuna localiza-se no Grupo São Roque. Tal grupo, conforme descrição na caracterização geológica, inclui-se no Complexo Cristalino e possui sua formação litológica no Proterozóico Superior.

No Grupo São Roque predomina a exploração mineral de substâncias não metálicas. Todavia, apesar da pouca expressividade dos bens metálicos nesse Grupo geológico, é possível encontrar setores onde a Magnetita ocorre em forma de veio encaixado em filitos e quartzitos, conforme já se mencionou. Essas áreas são adjacentes ao stock metabasítico do município de Pirapora do Bom Jesus, onde ocorreu a extração incipiente desse minério no passado.

É fato histórico a exploração de ouro no Pico do Jaraguá e na Serra do Boturuna. Esse mineral aparecia em veios de quartzos com alguns sulfetos associados. Entretanto, a região destaca-se pela exploração de minerais não metálicos, principalmente, pelos quartzitos (metarenitos) as rochas calcárias com numerosas lentes.

Apesar da intensa exploração mineral que a Serra do Boturuna já se expôs, atualmente, há somente duas minerações que possuem lavras ativas na Serra: a Lolli Extrativa de Minerais Ltda. e a Armando Angelini. Contudo, possivelmente, a Hipermix Serviços de Concretagem, que adquiriu os direitos minerários da Saint-Gobain Quartzolit, executará essas lavras.

O quadro atual sobre a espacialização da atividade de exploração mineral na região da ANT da Serra do Boturuna se expõe por meio da análise do Mapa 13 e da Tabela 31. As substâncias exploradas são empregadas, sobretudo, na construção civil. Apesar de determinadas ressalvas que serão descritas no decorrer do trabalho, essas mineradoras estão regularizadas junto à SMA, ou seja, possuem PRADs ou EIA-RIMAs aprovados. Todos os processos de lavra são anteriores ao tombamento da Serra e a área total de abrangência das poligonais minerárias sob o regime de concessão corresponde a 236 ha. $\left(2,36 \mathrm{~km}^{2}\right)$. 


\section{Mapa 13 - Poligonais Minerárias na Região da ANT da Serra do Boturuna, Estado de São Paulo}

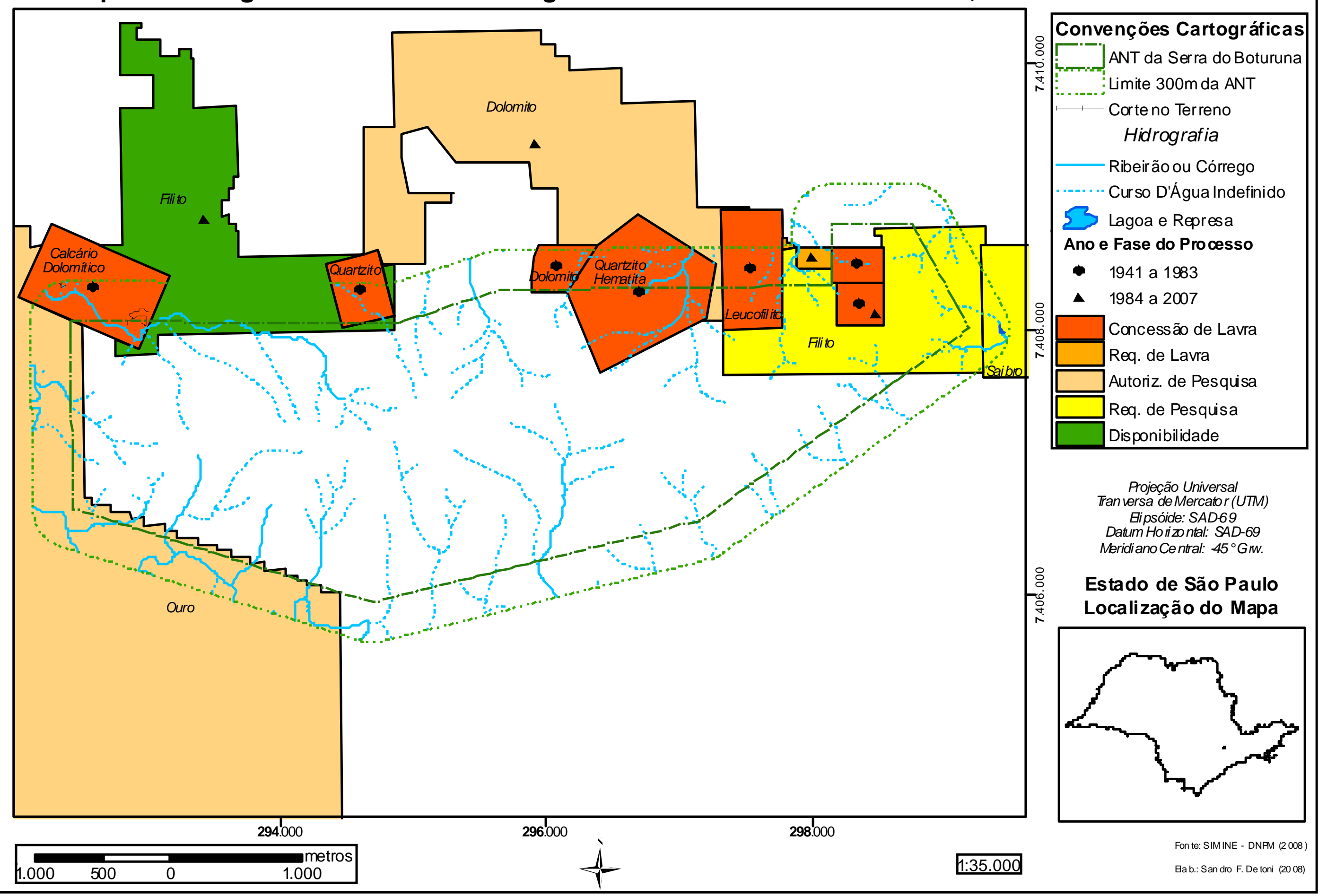


Tabela 31 - Poligonais minerárias sob regime de concessão de lavra na Serra do Boturuna, Estado de São Paulo

\begin{tabular}{|c|c|c|c|c|c|c|}
\hline Processo & Ano & $\begin{array}{l}\text { Área } \\
\text { (ha) }\end{array}$ & Nome & Substância & $\begin{array}{c}\text { Situação da } \\
\text { Lavra }\end{array}$ & $\begin{array}{c}\text { Situação } \\
\text { - SMA }\end{array}$ \\
\hline 6532 & 1941 & 58,80 & $\begin{array}{c}\text { Lolli Extrativa } \\
\text { de Minerais } \\
\text { Ltda. }\end{array}$ & $\begin{array}{c}\text { Calcário Dolomítico e } \\
\text { Dolomito }\end{array}$ & Ativa & $\begin{array}{l}\text { PRAD } \\
\text { Aprovado }\end{array}$ \\
\hline 2792 & 1948 & 20,00 & $\begin{array}{c}\text { Lolli Extrativa } \\
\text { de Minerais } \\
\text { Ltda. }\end{array}$ & $\begin{array}{l}\text { Caulim e Quartzito } \\
\text { (Metarenito) }\end{array}$ & Ativa & $\begin{array}{l}\text { PRAD } \\
\text { Aprovado }\end{array}$ \\
\hline 6676 & 1957 & 13,55 & $\begin{array}{c}\text { Armando } \\
\text { Angelini }\end{array}$ & Dolomito & Ativa & $\begin{array}{c}\text { PRAD } \\
\text { Aprovado }\end{array}$ \\
\hline 854 & 1959 & 80,85 & $\begin{array}{l}\text { Armando } \\
\text { Angelini }\end{array}$ & $\begin{array}{c}\text { Argila, Hematita e } \\
\text { Quartzito (Metarenito) }\end{array}$ & Ativa & $\begin{array}{c}\text { PRAD } \\
\text { Aprovado }\end{array}$ \\
\hline 800684 & 1972 & 41,40 & $\begin{array}{c}\text { Minarca } \\
\text { Indústria e } \\
\text { Com. de } \\
\text { Minerais } \\
\text { Ltda. } \\
\end{array}$ & Lecoufilito e Quartzito & Desativada & $\begin{array}{l}\text { PRAD } \\
\text { Aprovado }\end{array}$ \\
\hline 820457 & 1979 & 11,52 & $\begin{array}{c}\text { Hipermix } \\
\text { Serviços de } \\
\text { Concretagem } \\
\text { Ltda. } \\
\end{array}$ & Quartzito & $\begin{array}{l}\text { Aquisição de } \\
\text { Direitos } \\
\text { Minerários }\end{array}$ & $\begin{array}{l}\text { EIA-RIMA } \\
\text { Aprovado }\end{array}$ \\
\hline 820561 & 1979 & 9,88 & $\begin{array}{c}\text { Hipermix } \\
\text { Serviços de } \\
\text { Concretagem } \\
\text { Ltda. }\end{array}$ & Quartzito & $\begin{array}{l}\text { Aquisição de } \\
\text { Direitos } \\
\text { Minerários }\end{array}$ & $\begin{array}{l}\text { EIA-RIMA } \\
\text { Aprovado }\end{array}$ \\
\hline
\end{tabular}

Fonte: consulta à SMA em 2007

Pode-se afirmar que a exploração mineral da Serra do Boturuna balizouse na clandestinidade e no emprego de técnicas e métodos de lavra inadequados que comprometeram a paisagem desse maciço quartzítico. Atualmente, a Serra possui diversos indícios que demonstram isso e, mesmo com a diminuição da atividade mineral, é possível notar muitas cavas onde ocorreu a mineração irregular. Nesses locais, as lavras são, prioritariamente, de quartzito friável, utilizado como areia na construção civil. A exploração do quartzito maciço ocorre de forma esporádica, sendo um subproduto da exploração do friável. O quartzito maciço, devido à sua resistência, é comercializado como brita. Contudo, a exploração dessa rocha não ocorre em maior escala, principalmente, porque o método de lavra possui um custo maior.

Os principais produtos explorados pelas mineradoras na Serra do Boturuna são os quartzitos friáveis (muitas vezes metarenitos), os filitos e os calcários (calcário dolomítico e dolomito). 


\subsubsection{Quartzito}

A principal área de exploração de quartzitos (muitas vezes denominados como metarenitos) na RMSP localiza-se em Pirapora do Bom Jesus. No entanto, deve-se mencionar o fato que a região de Mogi das Cruzes também já foi considerada um importante centro produtor desse mineral. Em Pirapora do Bom Jesus, as principais reservas estão na Serra do Boturuna e no Morro de Jaguacoara.

Os quartzitos sustentam os relevos mais destacados da paisagem regional e apresentam-se em formas variadas. A forma lenticular é a predominante na ANT da Serra do Boturuna. Porém, de forma geral, os quartzitos apresentam-se com estrutura foliada. Os corpos quartzíticos também podem ser silicificados, daí, apresentam-se com estrutura maciça devido à recristalização dos grãos de quartzo e o preenchimento intersticial da rocha pela sílica. Produto do metamorfismo do arenito, eventualmente, os quartzitos podem possuir cimento argiloso que, com o metamorfismo, é transformado em muscovita (IPT, 1984).

A granulação dos quartzitos pode variar de fina a grossa e a orientação dos seus grãos de quartzo ocorre ao longo de planos bem desenvolvidos. $O$ quartzo compõe mais de $80 \%$ dessa rocha metamórfica que também pode conter mica branca e feldspato. Os minerais acessórios mais comuns encontrados são os seguintes: a magnetita, a apatita, a turmalina e o zircão. Na região da Serra do Boturuna, encontram-se outras rochas intercaladas aos quartzitos, como os metarenitos finos arcoseanos, os anfibolitos, os filitos e os xistos.

Com relação à exploração econômica do quartzito, torna-se necessário efetuar a distinção entre os quartzitos e os metarenitos. "Embora tratadas comercialmente como quartzitos, essas substâncias variam litologicamente desde quartzitos puros ou quartzitos micáceos até metarenitos arcosianos." (EMPLASA, 1981, p. 18).

Diferente da região de Mogi das Cruzes, onde predominam os quartzitos puros, ou seja, com maior grau de metamorfização do arenito, Pirapora do Bom Jesus destaca-se pela ocorrência e pela exploração, sobretudo, dos quartzitos 
mais friáveis e dos metarenitos. Deve-se destacar que o PDM de Pirapora do Bom Jesus afirma que:

[...] o 'quartzito' existente em Pirapora do Bom Jesus é, na realidade, um metarenito arcosiano rico em feldspato semidecomposto. Tratado, impropriamente, por alguns mineradores de caulim ou leucofilito, isto dificulta a tabulação dos dados de produção e reservas desse minério. (EMPLASA, 1982, p. 10).

O núcleo do maciço da Serra do Boturuna possui como embasamento o quartzito com alta concentração de sílica e constitui-se de uma rocha extremamente maciça. Porém, atualmente, a exploração comercial concentrase no metarcóseo e no metarenito presentes no entorno da Serra.

Os diferentes tipos de quartzitos são utilizados em distintos setores econômicos. Essa rocha é utilizada, principalmente, pelas indústrias de vidro, pelas metalúrgicas, como refratários, pelas cerâmicas, na preparação de abrasivos e na construção civil.

Na maioria das vezes, os quartzitos para fins industriais são empregados na sua forma compacta. Contudo, conforme sua utilização, a rocha é britada e moída na fração granulométrica desejada (EMPLASA, 1982).

A lavra do quartzito puro é a céu aberto com desmonte por explosivos. De acordo com o PDM de Pirapora do Bom Jesus, em meados da década de 1980, o quartzito extraído no município de Pirapora do Bom Jesus era britado e vendido para as indústrias de refratários da região de Suzano. Atualmente, conforme descrito, as mineradoras que atuam na região da Serra do Boturuna não lavram mais o quartzito puro.

O quartzito utilizado na produção de refratários necessita de elevada pureza de sílica, com baixos teores de álcalis, ferro e alumínio, pois devem possuir resistência às altas temperaturas (em torno de $1.680^{\circ} \mathrm{C}$ ).

Comumente denominado como quartzito, o metarcóseo encontra-se no entorno da Serra do Boturuna. Esse mineral é utilizado na fabricação de material de revestimento em construção (reboco e massa fina).

O metarenito arcosiano, rico em feldspato semidecomposto, possui granulometria mais fina, sendo utilizado na fabricação de fertilizantes, no setor cerâmico e para a produção de massas especiais utilizadas em revestimentoreboco e massa fina. $\mathrm{O}$ desmonte para a extração do metarenito arcosiano é 
efetuado por meio de pás-carregadeiras e trator lâmina para a remoção dos rejeitos e preparação da praça (EMPLASA, 1982).

Tanto a exploração do quartzito como a do metarenito provoca sensíveis impactos na paisagem local, principalmente, pelo método de lavra.

O baixo valor do capital investido na extração de quartzitos e
metarenitos, aliados às boas condições de mercado, facilitam o
estabelecimento de grande número de pequenas empresas que
trabalham sem nenhuma orientação técnica, resultando em
perigosos trabalhos de lavra, má disposição dos rejeitos, lavras
abandonadas com processo acelerado de erosão e assoreamento de
córregos, freqüentes na região metropolitana. (EMPLASA, 1982, p.
7).

De acordo com o DNPM, há duas mineradoras que possuem lavras ativas legalizadas dessas substâncias minerais na Serra do Boturuna: a Lolli Extrativa de Minerais Ltda. e a Mineração Armando Angelini. Tais empresas exploram, principalmente, o metarcóseo e o metarenito. Entretanto, na região da Serra, há mais duas empresas que possuem Decreto de Lavra: a Minarca Indústria e Comércio de Minerais Ltda. e a Saint-Gobain Quarzolit Ltda, que cedeu seus direitos para a Hipermix Serviços de Concretagem Ltda.

Conforme mencionado, as dificuldades em definir os quartzitos no momento da exploração da rocha fazem com que a tabulação de seus dados para fins estatísticos seja imprecisa. Nos anuários minerais produzidos pelo DNPM, o quartzito, o metarcóseo e o metarenito arcosiano são tabulados em diferentes grupos de substâncias. Os critérios de levantamento estatísticos das reservas e da sua produção dependem de sua utilização e da fonte de obtenção dos dados por parte do DNPM. Os quartzitos industriais podem ser tabulados como quartzito industrial ou como areia industrial. De forma geral, o quartzito, o metarenito e o arenito para fins industriais são denominados, respectivamente, como quartzito industrial e areia industrial.

O DPNM organiza seus anuários de acordo com os grupos de substâncias. Cada grupo é composto por substâncias que atendam os seguintes critérios: um determinado segmento do mercado, que possuem as mesmas utilizações ou constituem-se como fontes de um mesmo elemento de interesse econômico.

Com relação aos quartzitos, os dados são agrupados conforme o Quadro 7. Assim, o quartzito industrial encontra-se no grupo das areias industriais e os quartzitos ornamentais estão no grupo das rochas ornamentais. 
Porém, deve-se ressaltar que os dados sobre as reservas de quartzitos podem ser subestimados, pois as reservas de quartzitos para o emprego na construção civil, possivelmente, não são incluídas no grupo das areias industriais, mas das areias comuns.

Os materiais que compõem o grupo das areias industriais são obtidos pelo beneficiamento das seguintes substâncias: as areias quartzosas, os arenitos (ou metarenitos) e os quartzitos. $O$ beneficiamento dessas substâncias ocorre por processos de seleção granulométrica. As areias industriais são utilizadas, sobretudo, nas indústrias de vidro e fundição. Assim, o beneficiamento tem $o$ intuito de retirar as impurezas $e$ as frações granulométricas sem valor econômico. Conforme a aplicação industrial utilizase uma determinada classe granulométrica. Daí resulta a diferença fundamental das areias empregadas na construção civil que não necessitam de um processo de seleção granulométrica com determinada precisão.

Os quartzitos utilizados para fins de revestimentos entram no grupo de rochas ornamentais. Tal grupo engloba as rochas ornamentais de ardósia, de quartzito, de granitos e de mármores, empregados em revestimentos, em pisos, em pias, entre outros. Contudo, se considerarmos que a grande parte do metarenito explorado na Serra do Boturuna destina-se para a fabricação de massa fina para revestimento, há possibilidade da produção comercializada pelas mineradoras da Serra fazerem parte desse grupo.

Manteve-se contato junto ao DNPM para sanar tais dúvidas. Contudo, o diretor regional negou-se a fornecer informações sobre essas e outras questões, sob alegação que tal procedimento se configurava como uma consultoria. Por isso, por vezes, trabalha-se com a proposição de hipóteses.

O Estado de São Paulo possui importante destaque na produção de areia para a construção civil. Os anuários do DNPM não apresentam a descrição de produção por municípios, o que dificulta, ainda mais, a análise proposta, pois as mineradoras no Boturuna lavram o metarenito, especialmente, para a produção de areias para a construção ou emprego na indústria de massas fina. Com isso, os dados, referente à produção de areias industriais e areias comuns, podem estar superestimados ou subestimados. 
Outro problema relacionado à análise dos dados, está no controle da comercialização da produção bruta e beneficiada, pois existe a possibilidade da empresa que explora a rocha bruta também beneficiá-la no local da exploração.

Quadro 7 - Substâncias por grupo

\begin{tabular}{|c|c|}
\hline \multicolumn{1}{|c|}{ Grupo } & Substâncias \\
\hline \multirow{4}{*}{ Areias Industriais } & Areia Industrial \\
\cline { 2 - 2 } & Quartzito Industrial \\
\cline { 2 - 2 } & Quartzo \\
\cline { 2 - 2 } Rochas Ornamentais & Sílex \\
\cline { 2 - 2 } & Ardósia \\
\cline { 2 - 2 } & Quartzito Ornamental \\
\cline { 2 - 2 } & Rochas Ornamentais (Granito e Afins) \\
\cline { 2 - 2 } & Rochas Ornamentais (Mármores e Afins) \\
\hline
\end{tabular}

Fonte: DNPM (2006)

As reservas de areia industrial e de quartzito industrial estão distribuídas em diversos municípios do Estado de São Paulo. Deve-se ressaltar que se incluiu o grupo das areias industriais na análise, pois essas substâncias podem ser obtidas por meio da exploração tanto do arenito (ou do metarenito) como do quartzito. Como esses materiais possuem finalidades exclusivas em determinados segmentos industriais torna-se por conveniente considerar todas as reservas do Estado na análise comparativa.

Com relação à participação do Estado de São Paulo nas reservas medidas de quartzito industrial do país, o anuário mineral do DNPM (2006) demonstra uma participação em $63,20 \%$ da reservas do país. As maiores reservas do Estado localizam-se em Jundiaí, Itapeva e Itaoca. A somatória dessas reservas corresponde a 79,82 da reservas do Estado de São Paulo. O município de Pirapora do Bom Jesus participa, apenas, com 1,61\% das reservas Estaduais.

Ao possuir uma reserva medida e incluída nas estatísticas do anuário mineral, não significa que determinada substância é explorada pela empresa mineradora. Assim, Pirapora do Bom Jesus é o maior produtor de Quartzito Industrial do Estado de São Paulo. Ao analisar a Tabela 32, em 2006, de acordo com os dados de produção obtidos pelo recolhimento do CFEM, a produção desse município correspondeu a $60,13 \%$ da produção estadual. Destaca-se que Santana de Parnaíba registrou uma pequena produção de 
quartzito industrial em 2004, possivelmente, associada à exploração de outras substâncias.

Tabela 32 - Participação nas operações minerais de quartzito industrial e friável (Produção estimada conforme recolhimento do CFEM)

\begin{tabular}{|c|c|c|}
\hline \multirow{2}{*}{ Ano } & \multicolumn{2}{|c|}{ \% de Participação nas Operações Minerais no Estado } \\
\cline { 2 - 3 } & Pirapora do Bom Jesus & Santana de Parnaíba \\
\hline $\mathbf{2 0 0 4}$ & $75,10 \%$ & $0,03 \%$ \\
\hline $\mathbf{2 0 0 5}$ & $72,02 \%$ & - \\
\hline $\mathbf{2 0 0 6}$ & $60,13 \%$ & - \\
\hline
\end{tabular}

Fonte: DNPM - <www.dnpm.gov.br>. Acesso em: 2007.

A Tabela 32 também demonstra que a participação na produção Estadual de Pirapora do Bom Jesus na extração desse minério diminuiu. No entanto, segundo os valores das operações minerais dessas substâncias, verificou-se um aumento na produção de, aproximadamente, 55\%, no período de 2004 a 2006.

Sem considerar as inconsistências na tabulação das reservas e da produção, os dados descritos na Tabela 32 demonstram uma tendência de distribuição da exploração de quartzito industrial em outros municípios do Estado.

O Estado de São Paulo detém 78,54\% das reservas de areia industrial do país (DNPM, 2006). As principais reservas do Estado estão distribuídas nos municípios de Itirapina, Descalvado, Bofete e Analândia, o que demonstra certa tendência para a exploração das reservas do arenito Botucatu. As reservas desses municípios correspondem a $76,75 \%$ das reservas do Estado de São Paulo. O município de Pirapora do Bom Jesus participa somente em 0,32\% das reservas de areia industrial do Estado.

Ao analisar a exploração mineral em Pirapora do Bom Jesus com base no recolhimento da CFEM, verificou-se que a exploração do quartzito industrial ou friável. Por isso, tornou-se conveniente somar as reservas de areia e quartzito industriais, para verificar a participação de Pirapora do Bom Jesus no contexto estadual. Segundo os dados, em 2005, o município possuía 0,77\% das reservas do Estado.

A Tabela 33 demonstra certa estabilidade nas reservas de quartzitos de Pirapora do Bom Jesus, no período de 2001 a 2005. Como os valores 
dependem do agrupamento da substância, pode-se afirmar que no período de 2001 a 2005, não houve a inclusão de novas reservas, ou seja, não se solicitou novos requerimentos de lavra no município. Esses números também demonstram que, muitas vezes, não há uma padronização para essa tabulação. Dessa forma, a areia industrial proveniente do arenito ou metarenito pode ser tabulada como quartzito industrial. Deve-se observar que no ano de 2004, houve o registro de uma reserva de quartzito ornamental em metros cúbicos. Talvez, em outros anos, essa reserva tenha sido tabulada como quartzito industrial, sendo seus valores expressos em toneladas.

Tabela 33 - Evolução das reservas de areia industrial, quartzito industrial e quartzito ornamental em Pirapora do Bom Jesus - SP (2001 a 2005)

\begin{tabular}{|c|c|c|c|c|c|}
\hline \multirow{2}{*}{ Substância } & \multicolumn{5}{|c|}{ Ano } \\
\cline { 2 - 6 } & $\mathbf{2 0 0 1}$ & $\mathbf{2 0 0 2}$ & $\mathbf{2 0 0 3}$ & $\mathbf{2 0 0 4}$ & $\mathbf{2 0 0 5}$ \\
\hline Areia Industrial $(\mathrm{t})$ & 1.654 .213 & 1.040 .200 & 2.094 & 0 & 3.265 .035 \\
\hline Quartzito Industrial $(\mathrm{t})$ & 10.410 .633 & 10.410 .633 & 12.651 .237 & 11.894 .830 & 8.800 .217 \\
\hline Total $(\mathrm{t})$ & 12.064 .846 & 11.450 .833 & 12.653 .331 & 11.894 .830 & 12.065 .252 \\
\hline $\begin{array}{c}\text { Quartzito Ornamental } \\
\left(\mathrm{m}^{3}\right)\end{array}$ & 0 & 0 & 0 & $\mathbf{8 . 5 5 2 . 1 8 2}$ & 0 \\
\hline $\begin{array}{c}\text { Participação do } \\
\text { Município nas Reservas } \\
\text { de Areia e Quartzito } \\
\text { Industriais do Estado }\end{array}$ & $0,66 \%$ & $0,64 \%$ & $0,72 \%$ & $0,66 \%$ & $0,77 \%$ \\
\hline
\end{tabular}

Fonte: DNPM (2002; 2003; 2004; 2005; 2006)

Convém destacar que o Estado de São Paulo é o maior produtor de areias comuns, utilizadas na construção civil, com participação de 92,06\% da produção beneficiada do país, em 2005. Entretanto, esses dados também não estão organizados por municípios. Assim, é importante destacar que parte dessa produção pode incluir areia industrial ou quartzito industrial, agrupado na categoria de areias comuns.

Apesar das dificuldades para a análise dos dados, as informações descritas demonstram a importante participação de Pirapora do Bom Jesus no mercado de quartzito industrial e friável, considerado o principal produtor do Estado, em 2006. 


\subsubsection{Filito}

Além do quartzito, uma outra importante rocha do Pré-Cambriano encontrada na região da ANT da Serra do Boturuna é o filito. No grupo dos filitos estão incluídos metassiltitos e os filonitos que são encontrados em zonas de movimentação tectônica intensificada, resultado da trituração de rochas nessas áreas. Esse grupo rocha distribuísse uniformemente por toda área pesquisada.

O filito é uma rocha metamórfica de granulação muito fina e forte foliação, constitui-se de minerais micáceos, clorita e quartzo. Produto do metamorfismo do micaxisto, sua formação é resultado da recristalização do material argiloso que compõe essa rocha (IPT, 1984). Na sucessão metamórfica, o filito é um estágio intermediário entre o micaxisto e a ardósia. É possível encontrar reservas de micaxisto ao sul ANT da Serra do Boturuna.

Apesar de serem denominadas comercialmente como filitos, para as rochas de coloração mais claras aplica-se o termo leucofilito. Segundo o IPT (1984), nas áreas ao norte da Serra do Boturuna, encontram-se lavras de filitos claros ou leucofilitos.

Em algumas áreas do Grupo São Roque, os filitos estão intercalados por rochas calcárias e dolomíticas. Na região da ANT da Serra do Boturuna, esse tipo de embasamento ocorre, especialmente, a noroeste da Serra do Boturuna, onde há minerações de calcário-dolomito, especialmente, a mineração da Lolli Extrativa de Minerais Ltda.

Os filitos podem ser empregados em distintos setores. De forma geral, essas rochas são utilizadas como veículo para inseticidas, como carga para borracha, como carga para cerâmica vermelha e branca, como fundente na fusão da massa cerâmica para pisos e azulejos, no refino de óleo, como aglutinante de ração, como fertilizantes e como massa fina para a construção civil.

$\mathrm{Na}$ ocasião da elaboração do PDM da RMSP, os três principais municípios produtores de filito eram Pirapora do Bom Jesus, Santana de Parnaíba e Cajamar.

Os filitos lavrados em Cajamar eram destinados, principalmente, às indústrias de inseticidas e fertilizantes. A produção de Pirapora do Bom Jesus e 
Santana de Parnaíba tinha como mercado as indústrias cerâmica, de plásticos, de borracha e a de ração animal.

Uma das maiores aplicações do filito está na indústria cerâmica e na produção de fertilizantes. Segundo PDM de Pirapora do Bom Jesus, isso faz com que a comercialização do produto oscile continuamente, de acordo com a safra e entressafra agrícola. $O$ quadro da exploração do filito na região, na década de 1980, era distinto do atual.

Na região compreendida entre Santana de Parnaíba e Pirapora do Bom Jesus, dez minerações exploram filitos e outros tipos litológicos semelhantes, destinados especialmente às indústrias cerâmicas, de plásticos, borracha e ração animal, com produção mensal de cerca de 4 mil t. (EMPLASA, 1981, p. 17).

A exploração de filito requer baixo investimento de capital, característica semelhante às minerações de quartzito. Isso permite com que também se estabeleça um número grande de pequenas empresas na sua exploração.

O desmonte das jazidas é efetuado por trator de esteira, pá-carregadeira ou manualmente. O beneficiamento é composto por operações de secagem, moagem e ensacamento. No entanto, esses procedimentos provocam a suspensão de grande quantidade de poeira na atmosfera.

Para efeito estatístico, nos relatórios do DNPM, o filito está no grupo do Talco e Outras Cargas Minerais, conforme o Quadro 8.

Quadro 8 - Substâncias por grupo

\begin{tabular}{|c|c|}
\hline \multicolumn{1}{|c|}{ Grupo } & Substância \\
\hline \multirow{4}{*}{ Talco e Outras Cargas Minerais } & Agalmatolito \\
\cline { 2 - 2 } & Filito \\
\cline { 2 - 2 } & Pirofilita \\
\cline { 2 - 2 } & Serpentinito Industrial \\
\hline
\end{tabular}

Fonte: DNPM (2006)

Um aspecto importante sobre a mineração de filito relaciona-se a medição de suas reservas. "Por se tratar de mineração de pequeno porte, não há maiores preocupações por parte dos mineradores para conhecer a real dimensão das suas reservas." (EMPLASA, 1981, p. 15). Deve-se também destacar que a exploração de calcário pode influenciar na medição das reservas de filito. O calcário, normalmente, ocorre em forma de lentes 
intercaladas entre quartzitos e filitos. Na exploração do calcário, o filito se apresenta como um subproduto, logo, registra-se somente as reservas de calcário. Possivelmente, tal argumentação explique o porquê do não registro de reservas de filito para o município de Santana de Parnaíba em 2005. Porém, nota-se que o município possui operações minerais de filito que envolveram o recolhimento do CFEM.

As reservas medidas de filito em Pirapora do Bom Jesus, em 1981, eram de 4.073.290 t. (EMPLASA, 1981). O quadro atual demonstra um significativo aumento nessas reservas, o que garantiu uma expressiva participação do município na participação da reservas do Estado. Porém, os dados indicam o aumento significativo ocorreu somente em 2004.

De acordo com o DNPM (2006), Pirapora do Bom Jesus apresentou, em 2005, a seguinte reserva medida de filito: $11.587 .654 \mathrm{t}$, o que correspondeu a uma participação de $18,28 \%$ das reservas Estaduais.

De acordo com os dados, é possível afirmar que a produção de filito, atualmente, concentra-se em grande parte no Vale do Ribeira, especificamente, em Nova Campina e Itapeva. Os dados do DNPM (2006) demonstram que as reservas medidas nesses municípios, 2005, correspondem, respectivamente, a $31,45 \%$ e $27,83 \%$ das reservas do Estado.

Apesar da importante participação de Pirapora do Bom Jesus na composição das reservas de filito do Estado, o município apresenta moderada participação nas operações minerais dessa substância, segundo a Tabela 34. Convém analisar tais dados com certa ressalva, devido aos problemas relativos à medição das reservas. No entanto, as informações ajudam a descrever a importância das reservas de filito de Pirapora do Bom Jesus na composição do quadro Estadual.

Tabela 34 - Participação nas operações minerais de filito (Produção estimada conforme recolhimento do CFEM)

\begin{tabular}{|c|c|c|}
\hline \multirow{2}{*}{ Ano } & \multicolumn{2}{|c|}{ \% de Participação nas Operações Minerais no Estado } \\
\cline { 2 - 3 } & Pirapora do Bom Jesus & Santana de Parnaíba \\
\hline $\mathbf{2 0 0 4}$ & $6,29 \%$ & - \\
\hline $\mathbf{2 0 0 5}$ & $5,33 \%$ & $1,87 \%$ \\
\hline $\mathbf{2 0 0 6}$ & - & $3,52 \%$ \\
\hline
\end{tabular}

Fonte: DNPM/SISMINE - <www.dnpm.gov.br>. Acesso em: 2007. 
A Tabela 35 descreve confirma a exploração das reservas medidas de filito do Vale do Ribeira, principalmente, no município de Nova Campina que apresenta 83,25 da participação das operações minerais dessa substância.

Tabela 35 - Principais municípios na participação das operações minerais de filito no Estado de São Paulo (2006)

\begin{tabular}{|c|c|}
\hline Município & Participação (\%) \\
\hline Nova Campina & $83,25 \%$ \\
\hline Itapeva & $12,35 \%$ \\
\hline Santana de Parnaíba & $3,52 \%$ \\
\hline Piedade & $0,88 \%$ \\
\hline
\end{tabular}

Fonte: DNPM/SISMINE - <www.dnpm.gov.br>. Acesso em: 2007. Produção estimada conforme o recolhimento do CFEM

\subsubsection{Calcário e dolomito}

O calcário é uma rocha sedimentar de origem poligenéticas, assim, há calcários clásticos, químicos e orgânicos. Tal rocha possui coloração que pode variar de cinza, amarela ou preta. De forma geral, os calcários possuem granulação microscópica e são muito compactas (LEINZ; AMARAL, 1998).

Para ser considerado um calcário puro, a rocha deve possuir minerais que possuam acima de $30 \%$ de carbonato de cálcio $\left(\mathrm{CaCO}_{3}\right)$, sendo compostas, predominantemente, de aragonita ou calcita.

A diferença entre o calcário e o dolomito é, essencialmente, química. Assim, há possibilidade da gradação do calcário para o dolomito. A maior proporção do mineral dolomita $\left[\mathrm{CaMg}\left(\mathrm{CO}_{3}\right)_{2}\right]$ influenciará em sua denominação. Normalmente, quando uma rocha calcária possui o mineral dolomito, independente da proporção, denomina-se calcário dolomítico. No entanto, por convenção, se a rocha for constituída em mais de $50 \%$ de seu peso pelo mineral dolomita, utiliza-se essa última denominação. O calcário, comumente, apresenta magnesita $\left(\mathrm{MgCO}_{3}\right)$ e, dependendo do teor, pode ser considerado calcário magnesiano.

O calcário apresenta-se com estrutura maciça, granulação fina e cor cinza escura à cinza clara. O teor mínimo de $\mathrm{CaCO}_{3}$ é de $75 \%$ e o teor máximo de $\mathrm{MgCO}_{3}$ é de $7 \%$. Ocorrem faixas suficientemente puras (com baixo teor de magnesiano) que são exploradas para a fabricação de cimento. (EMPLASA, 1981, p. 9). 
O método de lavra do calcário é a céu aberto. O desenvolvimento de bancadas depende da tipologia da jazida. "As principais dificuldades observadas são o grande volume de cobertura de solo e o forte mergulho (inclinação) do corpo mineral, obrigando a um aprofundamento contínuo da lavra, uma vez que a espessura de material estéril aumenta gradativamente." (EMPLASA, 1981, p. 9).

O calcário é matéria-prima fundamental na fabricação de cimento. Além da indústria de cimento, essa rocha pode ser utilizada na produção de fertilizantes (como corretivo de acidez do solo), em siderúrgicas (como fundente) e na produção de cal.

$\mathrm{Na}$ região da ANT da Serra do Boturuna, o calcário, ou calcário dolomítico ocorre na forma de grandes lentes intercaladas aos quartzitos e filitos.

A principal área de ocorrência de calcário em Pirapora do Bom Jesus localiza-se ao longo de uma faixa ao norte desse município. Entretanto, há diversos outros corpos calcários de menores dimensões distribuídos pela região. Em Santana de Parnaíba, a principal ocorrência é num local denominado como Vau Novo, onde essa rocha foi intensamente explorada para a produção de cal. Esse corpo já foi intensamente lavrado na década de 1950, quando então produzia 60.000 sacos de cal por mês (KNECHT, 1950).

O calcário é distribuído no setor norte desse município sob a forma de diversas lentes estreitas e alongadas e de muitas ocorrências pontuais.

O maior problema na execução da lavra de calcário relaciona-se ao capeamento do material estéril. De acordo com o PDM de Santana de Parnaíba, as pesquisas realizadas para a execução de lavra no município indicaram uma proporção muito alta de material estéril nas jazidas de calcário da região. "Dados preliminares dessa pesquisa, fornecidos em 78, revelavam a presença de 4,5 milhões de toneladas de dolomito com teores de $\mathrm{CaO}$ e $\mathrm{MgO}$ ao redor de $50 \%$, contra um capeamento estéril de 7 milhões de toneladas." (EMPLASA, 1985, p. 35).

Esse fato possui relação direta com o forte mergulho que os corpos de calcários apresentam, sendo cobertos por um grande capeamento de solo.

O agrupamento nos anuários minerais do DNPM do calcário e do dolomito ocorre conforme o emprego da substância. Assim, essas substâncias, 
apesar de pequenas diferenças, são agrupadas em categorias distintas, conforme o Quadro 9.

Quadro 9 - Substâncias por grupo

\begin{tabular}{|c|c|}
\hline Grupo & Substâncias \\
\hline \multirow{2}{*}{ Calcário } & Calcário (Rochas) \\
\cline { 2 - 2 } & Calcita \\
\cline { 2 - 2 } & Calcita Ótica \\
\cline { 2 - 2 } & Conchas Calcárias \\
\hline \multirow{2}{*}{ Dolomito e Magnesita } & Dolomito \\
\cline { 2 - 2 } & Magnesita \\
\cline { 2 - 2 } & \\
\hline
\end{tabular}

Fonte: DNPM (2006)

A dificuldade em definir as distintas tipologias de calcários refletirá na análise das reservas e nas operações que envolvem o calcário, calcário dolomítico e o dolomito.

As reservas de calcário e dolomito do Estado de São Paulo concentramse, principalmente, nos municípios do Vale do Ribeira. Iporanga, Apiaí e Ribeirão Grande apresentaram, em 2005, respectivamente, 25,01\%, 20,14\% e 16,81 das reservas medidas de calcário do Estado. Com relação ao dolomito, destaca-se o município de Itararé que possui $37,16 \%$ das reservas medidas do Estado de São Paulo.

Santana de Parnaíba evidencia-se pela participação de 9,22\% nas reservas medidas de dolomito, em 2005. Pirapora do Bom Jesus possui apenas reservas de Dolomito, com participação em $0,67 \%$ das reservas do Estado.

A Tabela 36, que apresenta a evolução das operações minerais no período de 2004 a 2006, indica a ocorrência de operações minerárias de dolomito, em Pirapora do Bom Jesus, somente em 2006.

Apesar da pouca participação nas reservas de calcário dolomítico de Santana de Parnaíba, os dados da Tabela 36 demonstram que o município registrou uma considerável participação nas operações minerárias, em 2005. 
Tabela 36 - Participação nas operações minerais de calcário dolomítico e dolomito (Produção estimada conforme o recolhimento do CFEM)

\begin{tabular}{|c|c|c|c|c|}
\hline \multirow{2}{*}{ Ano } & \multicolumn{3}{|c|}{ \% de Participação nas Operações Minerais no Estado } \\
\cline { 2 - 5 } & \multicolumn{3}{|c|}{ Pirapora do Bom Jesus } & \multicolumn{2}{c|}{ Santana de Parnaíba } \\
\cline { 2 - 5 } & Calcário Dolomítico & Dolomito & $\begin{array}{c}\text { Calcário } \\
\text { Dolomítico }\end{array}$ & Dolomito \\
\hline 2004 & - & - & - & - \\
\hline 2005 & - & - & $76,31 \%$ & $44,75 \%$ \\
\hline 2006 & - & $0,34 \%$ & - & $78,29 \%$ \\
\hline
\end{tabular}

Fonte: DNPM/SISMINE - <www.dnpm.gov.br>. Acesso em: 2007.

Se considerarmos todas as tipologias de calcários, nota-se que Santana de Parnaíba possui uma posição de destaque na exploração dessas substâncias. No entanto, as lavras de calcário do município não se encontram na região da Serra do Boturuna.

Os dados também demonstram que Pirapora do Bom Jesus apresentou baixa participação das operações de dolomito. Destaca-se que a Companhia de Mineração Geral (COMGE) e a Lolli Extrativa de Minerais Ltda. exploram as lavras de calcários existentes no município.

\section{RECUPERAÇÃO DAS ÁREAS DEGRADADAS POR MINERAÇÕES}

A recuperação das áreas degradadas por mineração encontra jurisprudência em dispositivo constitucional. Contudo, até a década de 1980, as minerações não tinham obrigação legal de recuperar as áreas degradadas. $O$ estabelecimento da Política Nacional de Meio Ambiente, pela Lei Federal n. 6.938/81 (alterada pela Lei Federal 7.804/89), ao traçar as diretrizes básicas da política ambiental, indicava uma revisão dessa postura. O art. $2^{\circ}$., inciso VIII, descreve que a Política Nacional de Meio Ambiente possui, entre outros princípios, a recuperação de áreas degradadas.

A resolução CONAMA 1/86 impôs a obrigatoriedade do EIA-RIMA e a definição de medidas mitigadoras para os empreendimentos que alterassem as propriedades física, químicas e biológicas do meio ambiente e que, desse modo, afetasse a biota, as condições estéticas e qualidade dos recursos ambientais, assim, grande parte dos empreendimentos minerários se enquadram nessa categoria. 
No entanto, a regulamentação do art. $2^{\circ}$., inciso VIII da Lei Federal 6.938/81 decorre do Decreto Federal n. 97.632/89. O art. 1ํ. desse Decreto dispôs que os empreendimentos que se destinassem à exploração mineral deveriam, quando da apresentação do EIA-RIMA ao órgão ambiental competente, submeter também à aprovação do PRAD. Esse Decreto também exigia dos empreendimentos já existentes, a apresentação, no prazo máximo de 180 dias, de um plano de recuperação da área degradada.

O dever em recuperar as áreas degradadas por mineração possui também dispositivo legal no parágrafo $2^{\circ}$., do art. 225 da Constituição Federal de 1988. Segundo esse parágrafo, a exploração dos recursos minerais impõe a obrigação em recuperar o meio ambiente degradado, de acordo com a solução técnica exigida pelo órgão público competente.

Assim, a partir da disposição constitucional e da regulamentação do art. $2^{\circ}$., inciso VIII, da Lei Federal n. 6.938/81, as mineradoras tiveram que se adequar às novas exigências e providenciar a elaboração dos planos de recuperação das áreas degradadas pela atividade.

O art. 3o. do Decreto Federal n. 97.932/89 descreve que o objetivo da recuperação consiste no retorno do sítio degradado a uma forma de utilização, conforme um plano preestabelecido para o uso do solo. Com isso, o plano se estrutura com o intuito da obtenção de uma estabilidade do meio ambiente.

Outro importante instrumento jurídico no controle e, de certa forma, na condução das diretrizes de recuperação ambiental das áreas de atividade de exploração mineral refere-se às Resoluções CONAMA n. 9/90 e n. 10/90 que dispuseram sobre as normas específicas de licenciamento ambiental de extração mineral na fase de pesquisa. Deve-se ressaltar que a Lei Federal $\mathrm{n}$. $7.805 / 89$, dispõe, no art. 16 , que a concessão de lavra depende de prévio licenciamento do órgão ambiental competente. No entanto, essa lei exige o licenciamento somente para a fase de concessão de lavra, inclui-se também que a exigência não especifica a obrigatoriedade do licenciamento ambiental. (MACHADO, 2004).

O licenciamento ambiental e os planos de recuperação das áreas degradadas devem ocorrer segundo a determinação do órgão competente ou segundo os termos de autorização, de permissão, de licença e ou de concessão. 
Mapa 14 - Mineração Lolli Extrativa de Minerais Ltda. - Imagem Ortorretificada (2002) e Poligonais Minerárias

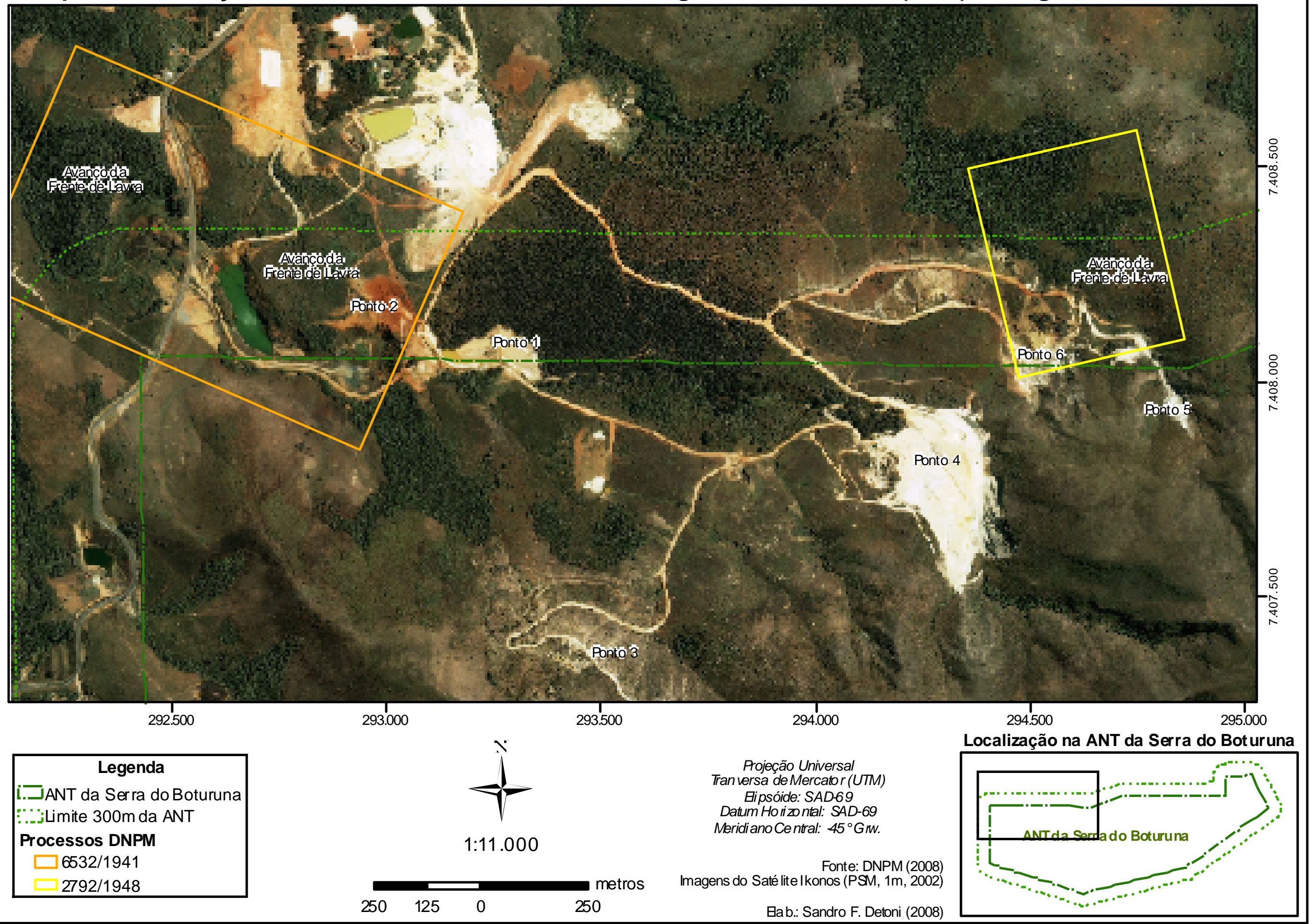


Com bases nas exigências legais, o Departamento de Avaliação de Impactos Ambientais (DAIA) da SMA conduziu o processo de regularização ambiental das minerações no Estado de São Paulo. Na Serra do Boturuna, três mineradoras apresentaram seus respectivos planos de recuperação. Uma mineradora, que obteve a concessão de lavra após a edição da Resolução CONAMA 01/86, apresentou O EIA-RIMA do empreendimento com o seu respectivo PRAD. De forma geral, essas mineradoras elaboram seus planos conforme a Resolução SMA 18/89, que estabeleceu um roteiro de trabalho e o conteúdo dos planos. Após a aprovação dos Planos, a fiscalização das medidas de recuperação fica a cargo da CETESB.

\subsection{LOLLI EXTRATIVA DE MINERAIS LTDA.}

Considerada uma das mineradoras legalizadas mais antigas de Pirapora do Bom Jesus, a Lolli Extrativa de Minerais Ltda. possui dois Decretos de Lavra no município que correspondem aos processos registrados no DNPM pelos números 6.532/41 e 2.792/48. Esses Decretos de Lavra the concederam o direito de explorar as seguintes substâncias minerais: calcário dolomítico, dolomito, mármore, quartzito e caulim. As poligonais minerárias referentes à exploração dessas substâncias encontram-se na propriedade de cinco milhões de $\mathrm{m}^{2}$, denominada Fazenda Lolli, que pertence à empresa de mineração. Parte das poligonais minerárias insere-se na ANT da Serra do Boturuna e zona de amortecimento de 300m, como se demonstra no Mapa 14.

O processo DNPM n. 6.532/41 refere-se a uma área de 58,80 ha. Solicitou-se o requerimento de pesquisa dessa área junto ao DNPM em 1941 e a concessão de lavra ocorreu em 1944, de acordo com o Decreto de Lavra n. 15.204/44, que concedia a empresa o direito de executar lavras de calcário dolomítico, dolomito e mármore na área da poligonal minerária requerida.

Já o processo n. 2.792/48 corresponde a uma área de 20 hectares com concessão de lavra obtida em 1954, por meio do Decreto de Lavra n. $35.662 / 54$, que concedeu o direito à mineradora de explorar lavras de quartzito e caulim. 


\subsubsection{Histórico da mineração}

A atividade de mineração na propriedade da Lolli iniciou-se, propriamente, em 1935. Na época, exploravam-se o calcário, a dolomita, a argila, o filito, o caulim e o quartzito. Esses materiais eram destinados às indústrias siderúrgicas, às cerâmicas, à vidraria, à construção civil e às indústrias de borracha. Parte da argila e do filito eram absorvidos por uma pequena olaria da própria mineradora, onde se fabricavam tijolos e telhas.

Em 1968, em virtude da construção da rodovia Castelo Branco a mineradora arrendou a propriedade para a Companhia Construtora Brasileira de Estradas (CCBE), que fora responsável pela construção de trechos da rodovia e utilizou como matéria-prima as substâncias minerais existentes na propriedade, principalmente, o quartzito. $\mathrm{Na}$ ocasião, os quartzitos foram extraídos em vários locais, inclusive em áreas que extrapolavam o limite das poligonais minerárias da Lolli no DNPM. De acordo com o Prof. Dr. Marco A. Rezende da Silva ${ }^{27}$, Engenheiro de Minas e consultor da mineração, atualmente, a mineradora tem obrigação legal na recuperação dessas áreas por ser a proprietária do terreno.

O tombamento natural da Serra do Boturuna, em 1983, não provocou alterações significativas na condução dos trabalhos nas lavras da região. No entanto, o aperfeiçoamento da legislação ambiental com a exigência de planos de recuperação de áreas degradadas fez com que a empresa mineradora se ajustasse às novas condutas legais. Em 1991, conduziu-se um processo, junto ao CONDEPHAAT, para a elaboração de um plano de recuperação das lavras incluídas no perímetro de tombamento e na faixa de amortecimento de $300 \mathrm{~m}$. Deve-se destacar que esse primeiro plano contemplava, unicamente, as lavras existentes no perímetro de tombamento e na zona de amortecimento. Apesar da exigência legal da apresentação de um PRAD à SMA, a empresa argumentou que o PRAD deveria ser apresentado somente ao CONDEPHAAT, pois a área de tombamento seria mais restritiva que as demais áreas do empreendimento. Dessa forma, a mineradora interpretou, erroneamente, que a competência Estadual para solicitar um PRAD seria CONDEPHAAT.

\footnotetext{
${ }^{27}$ Informação pessoal colhida por correio eletrônico em 2008
} 
O CONDEPHAAT, por sua vez, exigiu a elaboração de um PRAD para a área total do empreendimento, o que incluiu as áreas lavradas pela CCBE, na ocasião da construção da rodovia Castelo Branco, em 1968. Com isso, a mineração apresentou ao CONDEPHAAT, em 1999, um plano de recuperação para todas as áreas do empreendimento, o que perfez um total de 369 ha. Segunda a mineradora, durante dois anos houve a fiscalização e a adequação desse Plano para ajustá-lo às exigências do CONDEPHAAT, assim, sua aprovação se deu em 2001.

O PRAD apresentado ao CONDEPHAAT se atém, basicamente, aos processos de revegetação das áreas mineradas e ao tipo de utilização futura da área. Dessa forma, descreve-se que a área será utilizada para a prática de esportes não convencionais, denominados "radicais", que envolvem caminhadas em toda gleba, escalada em taludes em que a rocha se encontra exposta, esportes náuticos e esportes aéreos com possível ponto de partida na Serra do Boturuna.

Em 2003, a empresa recebeu um comunicado do DAIA/SMA que reprovou o PRAD aprovado pelo CONDEPHAAT. Para a mineradora, no âmbito jurídico, esse procedimento seria equivocado, pois não caberia ao DAIA/SMA reprovar uma decisão de um órgão colegiado constituído pelo Governo do Estado de São Paulo. Assim, a mineradora propunha que deveria ser encaminhada uma lista de exigências e não a reprovação.

Numa reunião entre a empresa, o DAIA e a CETESB decidiu-se sobre a apresentação de um novo PRAD com foco, especificamente, aos aspectos minerários que envolvessem os dois decretos de lavra. Elaborou-se esse PRAD com base nas recomendações da Resolução SMA n.18/89. Para a mineradora, a resolução abordava aspectos genéricos, logo, o Plano apresentado ao órgão responsável pelo tombamento da Serra seria mais detalhado. Por isso, no Plano apresentado à SMA, mantiveram-se os tópicos já aprovados pelo CONDEPHAAT que não foram questionados pelo DAIA/SMA.

O PRAD apresentado à SMA, refere-se aos seguintes processos: CETESB n. 32/0573/94, SMA n. 13.610/02 e ao SMA n. 13.751/03. O documento descreve o histórico da mineração, a caracterização do meio físico e biológico da região, o PL, as medidas mitigadoras, a proposta de utilização futura da área e o próprio plano de recuperação das áreas degradadas pela 
mineração. Complementam o PRAD, um documento de cessão dos direitos minerários e o Parecer Técnico de Consultoria Particular contrata pela SMA. Assim, partiu-se da análise do PL que compõe o PRAD referente às duas poligonais minerárias.

Os Planos de Lavra não estabeleceram a configuração final dos pits ${ }^{28}$ de mineração, devido ao não encerramento dos projetos de expansão das áreas de lavra que, de acordo com o documento, ainda se encontravam em desenvolvimento pela equipe técnica da mineradora. Contudo, indicaram-se, genericamente, a expansão das áreas de mineração com base no potencial das jazidas nas poligonais minerárias.

\subsubsection{Plano de lavra - Processo n. 6.532/41 (Decreto de Lavra $n$. 15.204/44)}

O PL apresentado à SMA, referente à poligonal minerária n. 6.532/41 corresponde aos seguintes períodos de exploração: 2004 a 2007, 2007 a 2009 e cava final.

O decreto de lavra dessa poligonal autorizou a exploração do calcário dolomítico, do dolomito e do mármore. Entretanto, explorou-se, no decorrer dos anos, predominantemente, o calcário dolomítico. O requerimento das demais substâncias deve-se, sobretudo, a uma questão econômica e comercial. Como o calcário dolomítico era lavrado em blocos, muitas empresas mineradoras, na década de 1950 e 1960, atribuíram a essa substância o nome comercial de mármore, pois se agregava um maior valor de venda ao produto. Deve-se distinguir que, apesar de semelhantes, o calcário é uma rocha sedimentar química e o mármore é uma rocha metamórfica. Já com relação ao dolomito, a distinção é, essencialmente, química, assim, não é interessante, em termos comerciais, a distinção entre o dolomito e o calcário dolomito (LOLLI, 2004).

Desenvolveu-se a lavra de calcário dolomito a céu aberto com a constituição de bancadas que variaram entre 12 e 16m. Utilizam-se explosivos

\footnotetext{
${ }^{28}$ Os mineradores utilizam o termo inglês pit para descrever a área de exploração. Em inglês, o termo pit pode significar mina.
} 
por perfuração pneumática para o desmonte da rocha. No PL apresentado ao DNPM, não se uniformizou as alturas das bancadas. No entanto, como as bancadas antigas já possuíam seus acessos, a mineradora propôs a execução dessas frentes de lavra, pois essa cava é a única ativa na poligonal minerária. O plano prevê a constituição de várias bancadas nessa frente de lavra, porém, propôs-se a homogeneização de suas alturas em $15 \mathrm{~m}$, com a largura das bermas de $10 \mathrm{~m}$ e a inclinação dos taludes de 15\%. A cota de fundo da cava deve chegar a $695 \mathrm{~m}$, atualmente, a cota está em $705 \mathrm{~m}$.

As bancadas devem possuir o mesmo padrão, independente, da substância a ser lavrada, pois a padronização, segundo o PRAD, permite a diminuição dos custos de lavra e facilita as operações, assim, evitam-se os erros operacionais, independente do minério. $O$ estabelecimento de cotas também facilita o desmonte dos materiais. A única restrição à padronização do método de lavra relaciona-se à lavra de caulim, uma vez que essa substância pode ser lavrada em tiras, mas a empresa optou por não variar o método.

Outra justificativa para a utilização do método de bancadas, refere-se à possibilidade de uma melhor drenagem da área. Essas bancadas são, relativamente, baixas, o que reflete num melhor controle da frente de lavra e no maior aproveitamento do minério.

O PRAD também sugere que a homogeneidade das bancada contribuirá, positivamente, para a recuperação da área, o que permitirá um mesmo padrão estético para toda área do empreendimento.

A interligação entre a Rodovia Castelo Branco e a Estrada dos Romeiros dividiu a poligonal em dois setores. Essa interligação foi construída na década de 1940, por Ubaldo Lolli (avó do proprietário) com o intuito de escoar a produção dessas duas áreas e diminuir o custo com o transporte, por isso, a estrada atravessa a poligonal minerária. A estrada passou a fazer parte da malha viária da região, vindo a ser administrada pelo Departamento de Estradas de Rodagem do Estado de São Paulo (DER), que a asfaltou. O PRAD destaca que, na apropriação da estrada pelo Governo do Estado, não houve um processo indenizatório, ou seja, ocorreu uma desapropriação indireta da propriedade. Logo, os proprietários reivindicam, não somente os valores da propriedade, mas também dos minérios do subsolo. 
Dessa forma, a área projetada para o ano de 2010 dependerá, não somente das condições de mercado, mas também da provável ação de desapropriação indireta que indicará a utilização futura das cava. Segundo Silva (2008), engenheiro de minas da Lolli, a empresa pretende solicitar uma prorrogação desse prazo. No geral, a cava final ocupará a seguinte área: 2,25 ha, sendo $150 \times 150 \mathrm{~m}$. No entanto, essas dimensões poderão ser menores se ocorrer o processo de desapropriação das áreas junto ao Governo do Estado ou à Prefeitura de Pirapora do Bom Jesus. Se a área não for desapropriada e o mercado consumidor de calcário dolomítico for favorável, pretende-se iniciar o licenciamento para a execução de lavra no restante da área. Independente da desapropriação, a Lolli compromete-se a executar o PRAD, que, segundo o documento entregue à SMA, já estava, parcialmente, em execução e sob fiscalização do CONDEPHAAT.

A expansão das frentes de lavra provocará, em determinados locais, a supressão da cobertura vegetal. $\mathrm{Na}$ poligonal referente ao processo $\mathrm{n}$. 6.532/41, essa expansão se dará a oeste da estrada intermunicipal e avançará sobre a vegetação secundária arbórea (capoeira) em, aproximadamente, 18 ha. A leste da estrada intermunicipal, a lavra avançar cerca de três hectares em área coberta por pasto sujo e algumas arvoretas, conforme o Mapa 14.

O empreendimento apresenta características de uma pequena mina de calcário dolomítico. Nos doze meses anteriores à elaboração do PRAD, a mineração operou abaixo dos $5.000 \mathrm{~m}^{3} /$ mês. O aumento ou diminuição da produção depende muito da conjuntura do mercado. Há perspectiva de um aumento da produção e a viabilização da área do projeto 2010. Esse fator relaciona-se com a possibilidade de fechamento de algumas minerações de calcário na região. De acordo com o PRAD, a mineração COMINGE, em Pirapora do Bom Jesus, que lavra calcário para a COSIPA, apresenta sinais de exaustão de sua jazida. Isso estimularia a execução de novas jazidas de calcário, além do aumento de produção nas jazidas já existentes.

No contexto geral, o projeto de produção depende do consumo de materiais britados num raio de até $50 \mathrm{~km}$ da jazida. Estabelece-se esse raio devido ao baixo preço unitário das substâncias minerais exploradas, pois a viabilidade do empreendimento também depende do custo do transporte. 
O PDM de Pirapora do Bom Jesus de 1981, ou seja, anterior ao tombamento natural da Serra do Boturuna, dispunha que parte da poligonal minerária do processo n. 6.532/41 localizava-se em área permitida para a mineração e outra parte abrangia uma área permitida com restrições técnicas. Nesse sentido, o PDM determinou a recuperação do solo com o intuito de se efetuar a recomposição, na medida do possível, do quadro natural existente anterior aos trabalhos de lavra.

\subsubsection{Plano de lavra - Processo n. 2.792/48 (Decreto de Lavra n. $35.662 / 54)$}

Esse PL refere-se à exploração das poligonais que compreendem as lavras de quartzito e de caulim. Estipulou-se o desenvolvimento da lavra também em três etapas: 2004 a 2007, 2004 a 2009 e cava final.

Desde a década de 1960, exploram-se o quartzito e o caulim dessas áreas com escala de produção que variou em função do mercado consumidor. Nesse sentido, destaca-se um aumento significativo da produção na década de 1980, quando a Argamassas Quartzolit passou a ser um grande consumidor de quartzito da Lolli.

$\mathrm{Na}$ época da elaboração do PRAD, o quartzito era vendido tanto para a construção civil (aplicação na produção de massas especiais do tipo cimentcola Quartzolit e na produção de areia), como para a indústria siderúrgica (fundente e na formação de escórias, no processo de fluidização). No segmento industrial, o grande comprador da Lolli, são as seguintes empresas: COSIPA (na baixada santista) e a Companhia de Ferro e Ligas (em Itapeva). Já o caulim é vendido in natura para as indústrias de papel e celulose ou para as instalações de terceiros, no qual, após o processamento, podem ser utilizados como agente branqueador, como pigmentos em tinta automotiva, para a fabricação de borracha (cargas) ou como produtos químicos, os denominados veículos.

O PRAD destaca que poderá ocorrer um aumento significativo da produção devido à utilização do quartzito na indústria de informática: 
Como curiosidade, achamos interessante comentar que o Governo Japonês fez um contato com a empresa para a compra de quartzito de alto teor de $\mathrm{SiO}_{2}$, para a fabricação de chips de computadores (para exportação, o teor deve ser de $99,7 \%$ de $\mathrm{SiO}_{2}$, sendo que essa jazida apresenta, na parte mais rica, teor de 99,8\% de $\mathrm{SiO}_{2}$ ). A empresa pretende, nos próximos 4 anos, criar uma estrutura (ou associar-se com exploradores) para exportação de quartzito de alto teor de Sílica, gerando novos empregos e divisas para o país. (LOLLI, 2004 p. 29).

De acordo com Silva (2008), houve a visita de uma comitiva japonesa com intuito de acertar um contrato para a importação de quartzito com alto teor de $\mathrm{SiO}_{2}$. Porém, a equipe técnica da Lolli, para esse caso específico, posicionou-se contrariamente à assinatura do contrato com o Grupo Japonês, pois a entrega do material seria no sistema just-in-time, ou seja, com dia e hora para a entrega, atrelados a uma demanda inicial de 10.000 t. Na opinião da equipe técnica, o empreendedor não possuía estoque regulador em Santos São Paulo, Hokaido e Tóquio. Dessa forma, as empresas ficariam sujeitas às greves de auditores fiscais. Isso inviabilizaria o negócio, em virtude do valor multa contratual estipulada (US $\$ 500.000$ por dia de atraso).

Com relação ao método de lavra, conforme se mencionou, a mineradora optou pelos mesmos procedimentos empreendidos na lavra de calcário dolomítico, ou seja, a lavra é a céu aberto com a constituição de bancadas de $15 \mathrm{~m}$, inclinação de $15^{\circ}$ e bermas de $10 \mathrm{~m}$. No caso do quartzito, o desmonte do material ocorre por meio da utilização de explosivos. Após o desmonte, o material é carregado por carregadeira frontal e transportado por caminhões basculantes até o sistema de britagem que ocorre em duas fases. Na fase de peneiramento, seleciona-se a fração areia. $O$ processamento ocorre em via úmida com circuito fechado, assim, a água retorna às bacias de decantação. $\mathrm{A}$ via úmida faz com que o material seja vendido com umidade de $7 \%$. Deve-se destacar que a areia decantada nas bacias é comercializada como areia fina.

Para a mineradora, a demanda de produção de areia proveniente quartzito possui influência das políticas de financiamento habitacional para as pequenas construções. No entanto, deve-se ressaltar que Silva (2008) confirmou que as substâncias exploradas pela Lolli enquadram-se nos minerais de Classe VII, categoria dos minerais industriais.

$\mathrm{Na}$ lavra de caulim não se utilizam explosivos, assim, o corte do material é feito por trator. A descrição do método de lavra é bem sucinta, ou seja, não há um detalhamento dos procedimentos. 
A mineradora tem evitado processar o caulim, pois o mercado exige um processamento de alta qualidade com demanda, quase freqüente, por caulim micronizado. Há perspectiva de processamento do caulim na própria mina, para assim, agregar valor ao produto. No entanto, tal medida requer altos investimentos.

Nas áreas de contato entre o caulim e o quartzito, não se executa a lavra, em virtude do alto custo para retirar a fração grossa da faixa areia do caulim.

A empresa reafirmou que a recuperação das áreas degradadas nessa poligonal, durante a execução da lavra, ocorrerá na medida do possível. O Plano concluiu que o cronograma de recuperação dependerá da demanda de mercado dos materiais e do aproveitamento econômico da lavra.

Destaca-se que o PDM de Pirapora do Bom Jesus não detectou maiores restrições, referente aos trabalhos de lavra na poligonal minerária descrita.

\subsubsection{Medidas mitigadoras e recuperação das áreas de lavra}

No documento apresentado, há um detalhamento executivo das medidas de controle e de mitigação dos impactos ambientais. A elaboração das propostas mitigadoras partiu da avaliação de alguns impactos ambientais associados ao empreendimento e à indicação de seu controle. Ponderou-se que a mineração existe desde 1941, assim, exploração das frentes de lavra modificou, paulatinamente, o ambiente local, porém, destaca-se que a alteração ambiental na região é anterior à mineração e remonta o início da ocupação européia na região. O Plano indica que os maiores impactos relacionam-se à alteração da cobertura vegetal original. Tal impacto é de difícil reparação, seja em função da ocupação rural da maior parte da gleba (e da região), seja pela remoção do solo, principalmente, dos setores com as maiores declividades em parte da Serra do Boturuna. Esses setores apresentam áreas degradadas relacionados ao estabelecimento de processos erosivos fruto da exploração mineral. Nesse aspecto, o Plano faz alusão à utilização do material da Serra para a construção da rodovia Castelo Branco. 
Com relação à estocagem de solo das cavas abertas e a sua posterior utilização para a recuperação das frentes de lavra, a mineradora afirmou em seu relatório que a remoção da pequena camada pedológica ocorreu em 1941 (lavra de quartzito), ou seja, não havia a obrigação legal em efetuar tal procedimento. Destaca-se também que a exploração ocorreu em afloramentos de quartzito, porém, como o material é comercializado, principalmente, para a construção civil e para a indústria siderúrgica, busca-se o quartzito de baixa resistência mecânica com baixo teor de sílica, que se encontra nas camadas superficiais, logo, não há capeamento, ou presença de solo. Para a mineradora, se fosse explorado o quartzito com alto teor de sílica, mais da metade do volume da jazida passaria a se constituir por rejeito do processo de extração. O Plano ressalta que o custo de exploração e do processamento desse quartzito é muito alto, por isso, a opção em lavrar o quartzito de menor resistência.

A empresa pretende utilizar na recuperação das áreas degradadas, 0 material da frente de lavra de calcário dolomítico, que possui como cobertura pedológica o latossolo (terra-roxa). Segundo o PRAD, antes da execução dos trabalhos nessa frente de lavra, ocorrerá o decapeamento do solo por meio da utilização de um trator de lâmina e a posterior estocagem. No entanto, a mineradora não confirmou tal procedimento. $O$ documento também descreve que a lavra de rebaixo (calcário dolomítico) opera há mais de 60 anos e já está sendo recuperada com material de decapeamento e solo.

Os impactos ambientais, diretamente, associados ao empreendimento atual estão distribuídos na área de tombamento, na área de amortecimento de $300 \mathrm{~m}$ e nas demais áreas do empreendimento que estão ligadas às atividades extrativas.

De forma geral, a mineradora acredita que os impactos relacionam-se, sobretudo, à formação de taludes íngremes com alta instabilidade geotécnica.

Atualmente, o desenvolvimento da lavra ainda apresenta reflexos da tecnologia mais extrativista aplicada anteriormente no empreendimento. Desta forma, ainda podem ser vistos na área de mineração taludes altos, com mais de $12 \mathrm{~m}$ de altura, irregulares, aparentemente frutos de desmontes, decapeamentos ou simples extrações muitas vezes feitos ao acaso ou em trechos mais ricos ou fáceis de minerar. Embora de menor expressão territorial, trechos de locais terraplanados também apresentam características ambientais inadequadas, como ausência de cobertura vegetal. (LOLLI, 2004, p. 56). 
$\mathrm{Na}$ proposição de medidas mitigadoras, o documento apresenta uma análise individual das principais formas de degradação encontradas no âmbito das poligonais minerárias registradas no DNPM.

\subsubsection{Poligonal minerária do Processo n. 6.532/41}

Nessa poligonal minerária, também se descreveu as tipologias de degradação ambiental existentes dentro e fora da área de tombamento. Nas áreas de lavra incluídas no perímetro de tombamento, propôs-se a correção de falhas operacionais antigas em porções localizadas por meio de ações estabilizadoras. Tais ações envolvem a formação de taludes e bermas tecnicamente favoráveis, pois o local passou, totalmente, por processos de decapeamento.

Nos setores de lavra fora do perímetro de tombamento (dentro da faixa de $300 \mathrm{~m}$ ), o Plano descreve a existência de um talude muito alto, entre $25 \mathrm{e}$ $35 \mathrm{~m}$, subvertical, em rocha alterada e com cobertura pedológica ( 25 a $30 \mathrm{~m}$ ). De acordo com o PRAD, esse talude resultou da abertura da cava de mineração e sua característica favorece o estabelecimento de processos erosivos. Concluiu-se que tais efeitos serão eliminados com o desenvolvimento da lavra por meio da construção de taludes e bermas apropriados. Sugeriramse também adequações geotécnicas, proporcionadas pelo desenvolvimento da lavra, segundo os critérios técnicos de Engenharia de Minas.

O setor oeste da poligonal (oeste da estrada de interligação), aparentemente, apresenta-se estável com a presença de vegetação em alguns pontos que formam um anteparo. Contudo, há locais que possuem processos erosivos ativos, blocos de rochas alterados e solos instáveis. O PRAD indica a estabilização dos processos erosivos, juntamente com a remoção dos blocos de rochas.

Como medida mitigadora para os dois setores, propôs-se a construção de uma rede de drenagem com o intuito de se evitar a formação de processos erosivos. A recuperação da área também inclui trabalhos de reconfiguração topográfica por meio do retaludamento das frentes de lavras. 
Na cava atual, há uma lâmina d'água de, aproximadamente, $2.18 \mathrm{~m}$ onde se pretende remover a água e fazer um novo plano de drenagem em projeto específico. Atualmente, a cava faz parte do sistema de bacias de decantação que operam em circuito fechado. Assim, os trabalhos de exploração do calcário dolomítico ocorrem nas bancadas superiores.

Com relação à reabilitação da área, a mineradora interpretou que a resolução do CONDEPHAAT impõe que a recuperação da área deve ser baseada na utilização futura como atividade turística (Art. $4^{\circ}$. da resolução $\mathrm{n}$. 17/83).

De acordo com o projeto de recuperação da área, aprovado pelo CONDEPHAAT, a cava de calcário dolomítico será utilizada como uma lagoa para a prática de esportes náuticos (passeios de barco, jet-ski e esqui aquático). Por isso, estabeleceu-se que a cota de fundo da cava será de $695 \mathrm{~m}$ e a cota de superfície d'água será de $710 \mathrm{~m}$.

A análise das imagens de satélite permitiu identificar os principais pontos de degradação na área do empreendimento, entre os quais, o ponto 1, indicado no Mapa 14. De acordo com Silva (2008), esse ponto corresponde a uma antiga frente de lavra explorada no final da década de 1960. A mineradora propôs que a recuperação dessa área será por meio da recomposição vegetal com eucalipto para a exploração comercial. A área encontra-se na zona de amortecimento da ANT da Serra do Boturuna, assim, interpreta-se que a aplicação dessa medida deveria se condicionar aos objetivos do tombamento. No entanto, a resolução de tombamento, não impõe restrições à exploração comercial de eucalipto, tanto no perímetro de tombamento, tampouco na zona de amortecimento da ANT.

\subsubsection{Poligonal minerária do Processo n. 2.792/48}

A área da poligonal apresenta, basicamente, os mesmos problemas ambientais da poligonal anterior. Incluiu-se a não finalização das operações de decapeamento e o avanço da área de lavra, a sudeste, para fora dos limites da poligonal que, segundo o Plano, ocorreu na ocasião da construção da Rodovia Castelo Branco, quando as lavras da Lolli foram cedidas à outra empresa 
mineradora. Os pontos 2, 3, 4 e 5 no Mapa 14 indicam as frentes de lavra que correspondem à retirada de material para a construção da rodovia.

Nas áreas com embasamento quartzítico, os taludes são em rocha com blocos soltos ou suspensos e mergulhos desfavoráveis à estabilidade do solo e da rocha alterada. Tais características ocorrem, principalmente, nas porções mais altas na área da poligonal, em ambos os lados no trecho final da praça de lavra e no acesso à lavra. Avançam em cerca de $100 \mathrm{~m}$ no perímetro de tombamento. O PRAD propôs que o avanço da lavra contribuirá para a eliminação desses problemas geotécnicos, pois ocorrerá o retaludamento das cavas e a construção de taludes e bermas adequados.

$\mathrm{Na}$ área de exploração do caulim, dentro da faixa de $300 \mathrm{~m}$ (ponto 6), a espessura do solo e da rocha alterada é superior a $20 \mathrm{~m}$ com processos erosivos instalados, inclusive o início de voçorocamento. Propuseram-se trabalhos de retaludamento que adentrarão, provavelmente, na área tombada por cerca de $50 \mathrm{~m}$, em virtude do acesso aos equipamentos necessários à realização das operações.

Nas áreas mineradas fora das poligonais de concessão de lavra, os problemas ambientais são, basicamente, os mesmos. Propôs-se um programa de recuperação, sobretudo, para o aproveitamento futuro da área.

De forma geral, o PRAD diagnosticou que a degradação ambiental dentro da área tombada decorre da extração mineral desorientada que resultaram em pequenos cortes no perfil terreno. Esses taludes permaneceram abandonados sem a estabilização adequada. A principal área encontra-se entre as cotas 850 e $950 \mathrm{~m}$. Nessa área, estabeleceram-se frentes de mineração, não muito grandes, e taludes que não foram estabilizados e possuem trincas provenientes, possivelmente, dos desmontes efetuados.

Observaram-se áreas de empréstimo de materiais, dentro da faixa de $300 \mathrm{~m}$. Para a mineradora, utilizaram-se esses materiais, provavelmente, para a construção de acessos. Propõem-se a recuperação dessas áreas com a deposição de solo orgânico e posterior revegetação com gramíneas.

No tocante às medidas mitigadoras, o Plano sugere o emprego de drenos (valetas e canaletas) com o intuito de se evitar o estabelecimento de processos erosivos, juntamente com a melhoria da qualidade técnica das 
operações, o controle dos materiais particulados e o estabelecimento de bacias de decantação.

De forma geral, as obras de controle e mitigação, relacionam-se ao retaludamento, que implicam na abertura de acessos e remoção de material solo com o risco de escorregamentos, instalação de drenos em cristas e pés de taludes e a adequação da área, quando possível, para a revegetação, pelo menos, com gramíneas.

O PRAD destaca que o aprofundamento dos sulcos de drenagem natural, ocorre devido ao gradiente altimétrico do relevo. Isso ocasiona impactos que decorrem, principalmente, em regime torrencial, da grande mobilização de materiais (argila, areia e pedra). O resultado da remoção desse material pode ser o soterramento de áreas onde foram plantadas espécies vegetais de menor porte, o comprometimento dos acessos ou, até mesmo, a instalação de processos erosivos de voçorocamento, se o lençol freático for alcançado.

Os aprofundamentos dos sulcos de drenagem ocorrem, principalmente, em trechos da estrada intermunicipal e nas áreas das cavas de mineração, onde há o fluxo concentrado das águas pluviais. Propõem-se a captação e condução das águas pluviais nesses locais. Nos canais existentes em alta declividade, sugeriu-se dissipar a energia cinética do fluxo por meio da condução do canal para pequenas barragens vazadas construídas com pedras de mão e pequenos matacões que cortam, mas não impedem o caminho descendente d'água. Nas menores declividades, indica-se a cobertura vegetal do canal, conforme o solo e o revestimento atual. Em trechos com alta declividade, talvez, haja necessidade da construção de canais de escoamento impermeáveis para a adequada condução da água a montante, também se indicou a utilização de solo-cimento em camadas entre três e cinco centímetros ou uso de canaletas em concreto, mais dispendiosas. Nos taludes sem capeamento, a água deve ser conduzida para canais dissipadores de energia (escada).

O aumento da turbidez das águas e o assoreamento dos canais relacionam-se ao grau de proteção da cobertura vegetal dos solos, em locais 
que possuem índices pluviométricos altos, da mobilização de solos na operação de decapeamento ou explotação e da lavagem da $\mathrm{ROM}^{29}$ na unidade de beneficiamento. Os materiais tende a se depositar em condições de energia hidráulica mais baixa, o que provoca o assoreamento dos canais e a inundações periódicas.

A expansão da frente de lavra de quartzito ocorrerá no sentido nortenordeste, o que provocará a supressão de uma capoeira numa área de, aproximadamente, $4, .5$ ha. No restante da área, a vegetação constitui-se, sobretudo, por gramíneas e por algumas árvores/arvoretas dispersas. Para Silva (2008), embora a área esteja dentro da poligonal, pretende-se efetuar estudos para que a execução da lavra ocorra de forma racional e com o intuito de gerar poucos impactos.

O PRAD sugere que a expansão das frentes de lavra não inclua as áreas com vegetação remanescente, cujo interesse minerário é desprezível, Por isso, propô-se isolar as áreas de capoeiras médias existentes na faixa de $300 \mathrm{~m}$ de proteção à área de tombamento.

O Plano destaca que o projeto de turismo ecológico poderá valorizar o empreendimento e gerar uma rentabilidade superior à exploração mineral. Entre as particularidades desse projeto, enfatiza-se que:

A empresa pretende, nessas áreas de lavra, realizar atividades de passeio ecológico, esportes de vôo e, principalmente, mostrar ao visitante como uma mineração pode recuperar uma área, tentando reverter a imagem, que muitos têm, de que a mineração, e particularmente os mineradores, apenas degradam e, depois, abandonam as áreas. (LOLLI, 2004, p. 37).

O plano de recuperação apresentado ao CONDEPHAAT, que também compõe o PRAD, descreve que nas áreas de quartzito não será possível estabelecer uma vegetação de grande porte, em virtude da falta de substrato pedológico.

A mineradora interpretou que a atividade turística é uma exigência da resolução de tombamento. No entanto, o documento apresentado ao CONDEPHAAT e à SMA também sugere que a limitação do uso do solo deveria ser acompanhada de uma indenização.

O aproveitamento futuro da área em um projeto de atividade turística, por exigência da Resolução CONDEPHAAT $n^{\circ}$. 17./83, a

\footnotetext{
${ }^{29}$ Sigla em inglês de run of mine que significa produção bruta.
} 
princípio gerou uma certa limitação aos interesses da empresa, que poderia, caso não houvesse essa limitação, dar uma solução mais econômica à área (como loteamento industrial, por exemplo). Além disso, não houve indenização da área pelo Tombamento efetuado pelo Governo do Estado de São Paulo, tendo a empresa que arcar com o ônus da limitação, em proveito de toda a sociedade, o que poderia levar a empresa a pleitear uma indenização, pelo Tombamento, na justiça. Todavia, como a empresa que minera é a proprietária das terras (tanto a mineração quanto as terras que pertencem à Família Lolli) o aproveitamento futuro, como áreas de turismo, passou a ser uma prioridade para a mineração. (LOLLI, 2004, p. 46).

\subsubsection{Demais impactos comuns às lavras}

Para a mineradora, não há impactos significativos relacionados à capacidade produtiva agrícola dos solos, pois a atividade minerária se encontra numa área com relevo montanhoso, o que impossibilita a agricultura e, até mesmo, a pecuária e silvicultura, pela ausência ou pequena capacidade de sustentação dos solos nesses locais. A mitigação pela perda de áreas para a prática da silvicultura ou agropecuária se dará por meio o estabelecimento de solo orgânico na recomposição de áreas já mineradas, em bota-foras e nas bermas em rocha e em solo, o que permitirá, segundo o Plano, o restabelecimento de cobertura vegetal.

O Plano também discute os impactos oriundos das instabilidades em taludes induzidas por detonações e da poluição visual, fruto da abertura das frentes de lavra e do rebaixamento do relevo de morros isolados. Sugeriu-se que a mitigação se dará por meio do aperfeiçoamento técnico do método de condução da lavra.

No que diz respeito à poluição visual, o documento relaciona tais impactos negativos à alteração da paisagem, assim, que pode atingir dimensões regionais. Para o PRAD, a mineradora é percebida na paisagem local apenas na circunvizinhança e em alguns pontos mais altos ou próximos aos locais das lavras que se apresentam alterados ou com ausência de cobertura vegetal. A ausência de cortina vegetal e a expansão das áreas de lavra fazem com que se destaquem alguns setores. Na poligonal 6.532/41, há um pequeno trecho, com cerca de $200 \mathrm{~m}$, junto à estrada intermunicipal, e na parte alta da Serra do Boturuna. Na poligonal 2.792/48 se observa somente o impacto negativo sobre o aspecto topográfico da Serra do Boturuna. 
Destacam-se as áreas lavradas pela CCBE que são facilmente perceptíveis da estrada intermunicipal, mas não são possíveis de serem observados nas vizinhanças da gleba pela presença de morros altos. A mitigação do impacto negativo da paisagem advém do plano de revegetação e da formação de cortinas vegetais.

O Plano também menciona os impactos negativos referentes à poluição do ar, provocados pela utilização de equipamentos e veículos na área do empreendimento.

$\mathrm{O}$ documento propôs algumas medidas de controle às queimadas. Para o PRAD, essa prática é comum na região, sendo um procedimento de limpeza dos pastos e das áreas agrícolas. Essas queimadas, muitas vezes, fogem de controle e podem atingir as áreas protegidas.

Propôs também um plano de monitoramento de eficácia de ações de controle ou mitigação dos impactos ambientais e medidas recuperação adotadas.

\subsubsection{Plano de recomposição da cobertura vegetal}

O Plano de Revegetação, ou Recomposição da Cobertura Vegetal, complementou o PRAD, na forma de anexo. O documento descreve os tipos de vegetação secundária existentes no empreendimento e exibe uma lista de espécies a serem introduzidas. Também compõe o Plano, um detalhamento sobre a forma de preparo do substrato de plantio e as diretrizes de manejo das mudas.

O documento propôs como prioridade a introdução de espécies da família das leguminosas, pois tais espécies propiciam a recuperação da fertilidade dos solos. Essa família vegetal pode constituir até $60 \%$ da população a ser introduzida. Na família das leguminosas, a preferência será para as espécies fornecedoras de alimentação à fauna, principalmente, às aves.

As espécies mais tardias da flora nativa e que necessitem de sombreamento serão adquiridas e plantadas para os setores com maior cobertura arbórea do solo. $\mathrm{O}$ enriquecimento de machas de vegetação arbóreo- 
arbustiva, em grau médio de sucessão, ocorrerá por meio de espécies escrófitas.

Propôs-se também a formação de uma cortina vegetal na área do empreendimento com o intuito de minimizar o impacto negativo na paisagem, juntamente com a contenção dos particulados gerados nas atividades de mineração.

Para as áreas com solos ou subsolos (em termos pedológicos) descobertos, indicou-se a recomposição vegetal com cobertura herbácea por meio da associação de gramínea (Brachiaria decumbens) e de leguminosas de baixo porte. Estabeleceu-se essa recomposição em função do uso futuro da área que será para a pratica de vôo livre.

\subsubsection{O Cronograma do PRAD}

O PRAD interpreta que a execução do cronograma depende da dinâmica das atividades minerárias. Logo, vincula-se, sobretudo, ao desenvolvimento das atividades minerárias nas lavras de quartzito e de calcário dolomítico. Em função da escala de produção no período de elaboração do PRAD, tais reservas podem ser exploradas por um período, relativamente, longo, calculado em, aproximadamente, 30 anos. Assim, para a mineradora: "Evidentemente, não seriam satisfatoriamente atendidos os objetivos de recuperação e preservação ambientais perseguidos pelo Tombamento da Serra do Boturuna em período tão dilatado de tempo." (LOLLI, 2004, p. 08).

Por isso, o documento sugere que os serviços relacionados à recuperação da cobertura vegetal sejam iniciados de forma imediata, sobretudo nos setores afetados pela retirada de materiais para a construção da rodovia Castelo Branco e na estrada intermunicipal. De acordo com o PRAD, esses setores, naquele momento, não eram lavrados, apresentavam-se estáveis e parcialmente, recobertos por vegetação, o que tornava possível o adensamento com espécies arbóreas ou com cobertura vegetal herbácea. Nos setores a serem estabilizados geotecnicamente e nas áreas de lavra, o PRAD propôs que a implantação da vegetação depende da efetivação dos procedimentos de estabilização. Destaca-se a revegetação das bermas se dará de cima para 
baixo no relevo local. O PRAD destaca que as ações prioritárias devem ocorrer na área de tombamento e em sentido centrífugo. A previsão para a recuperação das áreas de lavra nas poligonais minerárias é de 30 anos. Contudo, a estabilização geotécnica ocorrerá entre cinco e 10 anos.

\subsubsection{Parecer técnico}

O PRAD apresentado à SMA foi submetido à emissão de um parecer técnico desenvolvido pela consultoria da Fundação Instituto de Pesquisas Econômicas (FIPE). Segundo a consultoria, a base de informações do parecer constitui-se pelo PRAD apresentado ao CONDEPHAAT, em 1999, pelo PRAD apresentado à CETESB em 2003, pelas complementações apresentadas em 2004 e pela vistoria realizada por técnicos da DEPRN, da CETESB, juntamente com os consultores da FIPE, em 2004.

O resultado do parecer técnico foi um relatório que descreve as seguintes temáticas: o estágio atual da composição vegetação no local, a caracterização dos taludes existentes na lavras, uma proposta de captação e condução das pluviais, juntamente com a proposição de estruturas dissipadoras de energia, a exigência do detalhamento do projeto de drenagem e do cronograma de execução do PRAD.

$\mathrm{Na}$ área da poligonal 6.532/41, observou-se que a lavra apresenta um talude único e irregular com cerca de $60 \mathrm{~m}$ e, na época, a atividade estava paralisada. Havia uma previsão de expansão da lavra por $90 \mathrm{~m}$ em direção ao nordeste e o rebaixo do piso da cava em $10 \mathrm{~m}$.

O relatório destaca que o avanço da lavra para o setor nordeste provocará a supressão da vegetação, que é composta por espécies pioneiras em estágio inicial e a ocorrência de árvores esparsas.

$\mathrm{Na}$ análise da poligonal 2.792/48, descreveu-se que as bancadas possuem cerca de $10 \mathrm{~m}$ e avanço ocorrerá, predominantemente, nos sentidos sudeste, com a lavra de quartzito e no sentido sudoeste por meio da lavra de caulim. Contudo, o parecer ressalta que o avanço da frente de lavra em direção ao sul e ao norte ocasionará a supressão da vegetação composta por espécies pioneiras. 
Mencionou-se no Plano a presença de cavas sem os devidos títulos minerários, dentro da área de tombamento e na faixa envoltória de $300 \mathrm{~m}$, em que se destacou a área de empréstimo de materiais para a construção da Rodovia Castelo Branco. Sugeriu-se para essas áreas que os trabalhos a serem desenvolvidos se assemelhem aos descritos para o setor de quartzito que ultrapassou os limites da poligonal DNPM n. 2.792/48. Tais procedimentos envolvem o controle de sulcos erosivos em encostas, a recuperação da capacidade de tráfego e o controle de drenagem nos acessos. Na vistoria, constatou-se que a empresa continuava lavrando a jazida, sob a alegação de estar recuperando área. Apesar dessas observações, aprovou-se o documento com exigências.

No contexto geral, as exigências relacionam-se ao detalhamento do projeto de recuperação. Destacam-se o pedido de regularização, junto ao DNPM, da área de exploração de quartzito que se encontra fora da poligonal, juntamente com a regularização das estruturas de beneficiamento.

O parecer propôs que nas áreas exploradas fora dos limites das poligonais deve-se elaborar um plano de recuperação que contenha uma base cartográfica e a configuração final dos taludes com a demonstração do sistema de drenagem e as medidas de proteção superficial de taludes com vegetação, que permita a estabilização da área. A execução da lavra de calcário a oeste da estrada de interligação não está autorizada (Área do Projeto Ano 2010). No entanto, a lavra poderá ser executada por meio do pedido de ampliação a ser instituído conforme a legislação vigente na época. Todos os procedimentos devem constar o monitoramente por meio de relatórios entregues ao DEPRN.

\subsubsection{Estágio atual da recuperação da área}

O impacto negativo na paisagem decorrente da exploração mineral na Serra do Boturuna ainda é muito marcante na Fazenda Lolli. Apesar da recuperação de alguns setores da propriedade por meio o incremento de vegetação, as áreas exploradas pela CCBE ainda se encontram totalmente degradadas com fortes processos erosivos e a completa desconfiguração topográfica, demonstradas na Figura 11. Deve-se destacar que a recuperação 
dessas áreas é, extremamente, onerosa, em virtude, dos procedimentos de lavras empregados. O método de retaludamento deve ser atrelado à reconfiguração topográfica da cava, pois as declividades não permitem emprego do primeiro procedimento.

Silva (2008) afirmou que grande parte das medidas propostas pelo PRAD está em fase de execução, entre as quais, a implantação dos viveiros de mudas, a recuperação dos acessos às áreas mineradas e o retaludamento de antigas cavas.

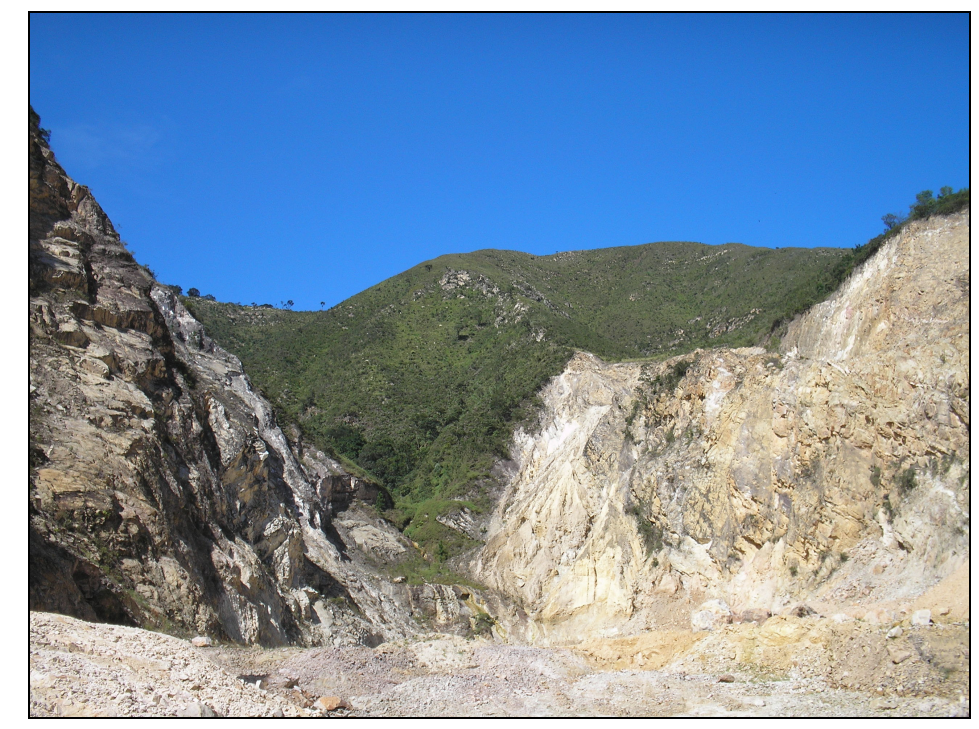

Figura 11 - Frente de mineração lavrada pela CCBE, abandonada e não recuperada (Sandro F. Detoni, abril de 2008)

É possível afirmar que o custo para a recuperação da área será muito alto e, dificilmente, a mineradora conseguirá atingir a harmonia paisagística prevista pelo tombamento da Serra, pois as medidas técnicas de recuperação topográfica são de difícil aplicabilidade.

O plano de recuperação, de certa forma, não condiz com os objetivos do tombamento da Serra do Boturuna, pois não há um detalhamento das medidas para a recuperação topográfica. Com relação ao projeto turístico, alguns pontos devem passar por uma nova análise, no âmbito do CONDEPHAAT, principalmente, na relação entre cobertura vegetal e a prática de vôo livre. Contudo, o estabelecimento de chácaras de lazer parece oportuno. Convém destacar que o avanço da frente de lavra de quartzito não inclui as vertentes da 
Serra do Boturuna, mas abrange a faixa de amortecimento de 300m (Figura 12).

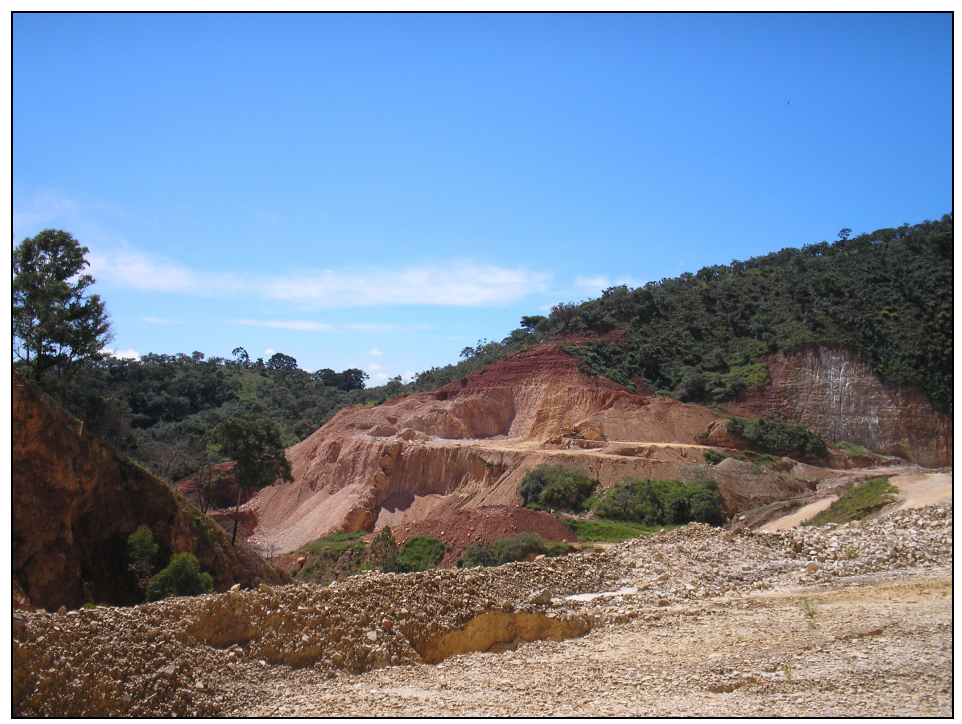

Figura 12 - Avanço da frente de lavra de quartzito: Processo DNPM n. 2.792/48 (Sandro F. Detoni, abril de 2008)

\subsection{MINARCA INDÚSTRIA, COMÉRCIO E MINERAÇÃO LTDA.}

A Minarca Indústria, Comércio e Mineração Ltda. possui como atividade principal a fabricação de argamassas e massa fina. Na década de 1970, a empresa solicitou um requerimento de lavra para a exploração de leucofilito (filito), ao lado da Mineração Armando Angelini, no Sítio Itaqueri. As características dessa substância são muito semelhantes a da argila. Assim, leucofilito fora utilizado pela própria indústria de materiais de construção para a fabricação de massa fina e adição dessa substância à cal (SONDA, 2004).

A empresa efetuou o requerimento de pesquisa da jazida mineral, junto ao DNPM, em 14/01/1972, e obteve o alvará de pesquisa, em 17/12/1973. O relatório de pesquisa foi entregue, em 1975, e aprovado pelo DNPM, em 24/08/1977. Na época, em decorrência dos procedimentos estabelecidos pelo PDM da RMSP, foi necessária a aprovação da atividade junto à SNM, conforme convênio estabelecido entre a Secretaria e o DNPM. Após a consulta por parte da mineradora, a mineração foi aprovada segundo as diretrizes de uso e ocupação do solo metropolitana. 
De acordo com o processo do DNPM n. 800.684/72, foi solicitada a exploração de leucofilito (filito) para uma área de 41,40 ha. Todavia, na área também se exploraram os metarenitos e os micaxistos, considerados subprodutos dos leucofilitos. O Mapa 15 representa a imagem de satélite da área com a delimitação da poligonal minerária registrada no DNPM.

As reservas de leucofilito, que constam no relatório de pesquisa, estão descritas na Tabela 37, o que correspondia a, aproximadamente, $25 \%$ das reservas do município em 1981, segundo a análise dos dados do PDM de Pirapora do Bom Jesus.

Tabela 37 - Reserva de leucofilito (filito) no Sítio Itaqueri

\begin{tabular}{|c|c|}
\hline Reserva & Quantidade (t) \\
\hline Medida & 1.004 .700 \\
\hline Indicada & 1.755 .200 \\
\hline
\end{tabular}

Fonte: Relatório de Pesquisa de Lavra (1975) in: SONDA (2004)

A Portaria de Lavra 514 de 06/041982 concedeu à empresa o direito para executar a lavra de argila na área solicitada. Convém destacar que, nesse caso, consideraram-se a argila, o leucofilito e o filito no mesmo grupo de substâncias minerais. Segundo o RAL de 2004, as reservas indicadas de leucofilito da área eram de 1.664.191 t. O RAL de 1996 apresentou uma produção bruta da mina de, apenas, 696 t. Entretanto, a capacidade instalada de produção era da ordem de 50.000 t/ano. Conforme a demanda de extração mensal, a exaustão jazida mineral foi estimada em 45 anos.

A Minarca afirmou que o custo de lavra inviabilizou, economicamente, o empreendimento, ao considerar que a quantidade máxima extraída era baixa, $3.000 \mathrm{t} / \mathrm{mês}$, ou seja, uma lavra de pequeno porte. O minério passou a ser adquirido de grandes produtores da região que, devido ao grande volume, possuem menor custo de produção. Assim, atualmente, a Minarca compra os insumos para a fabricação de argamassas da Mineração Armando Angelini. Apesar de não executar mais as lavras, a Minarca, segundo o Processo SMA n. 13.732/2004, tinha a obrigação legal de apresentar o PRAD do empreendimento que fora elaborado pela SONDA Serviços de Geotecnia S/C Ltda. e apresentado à SMA, em julho de 2004. 


\section{Mapa 15 - Minarca Indústria, Comérico e Mineração Ltda. Imagem Ortorr etificada (2002) e Poligonal Minerária}

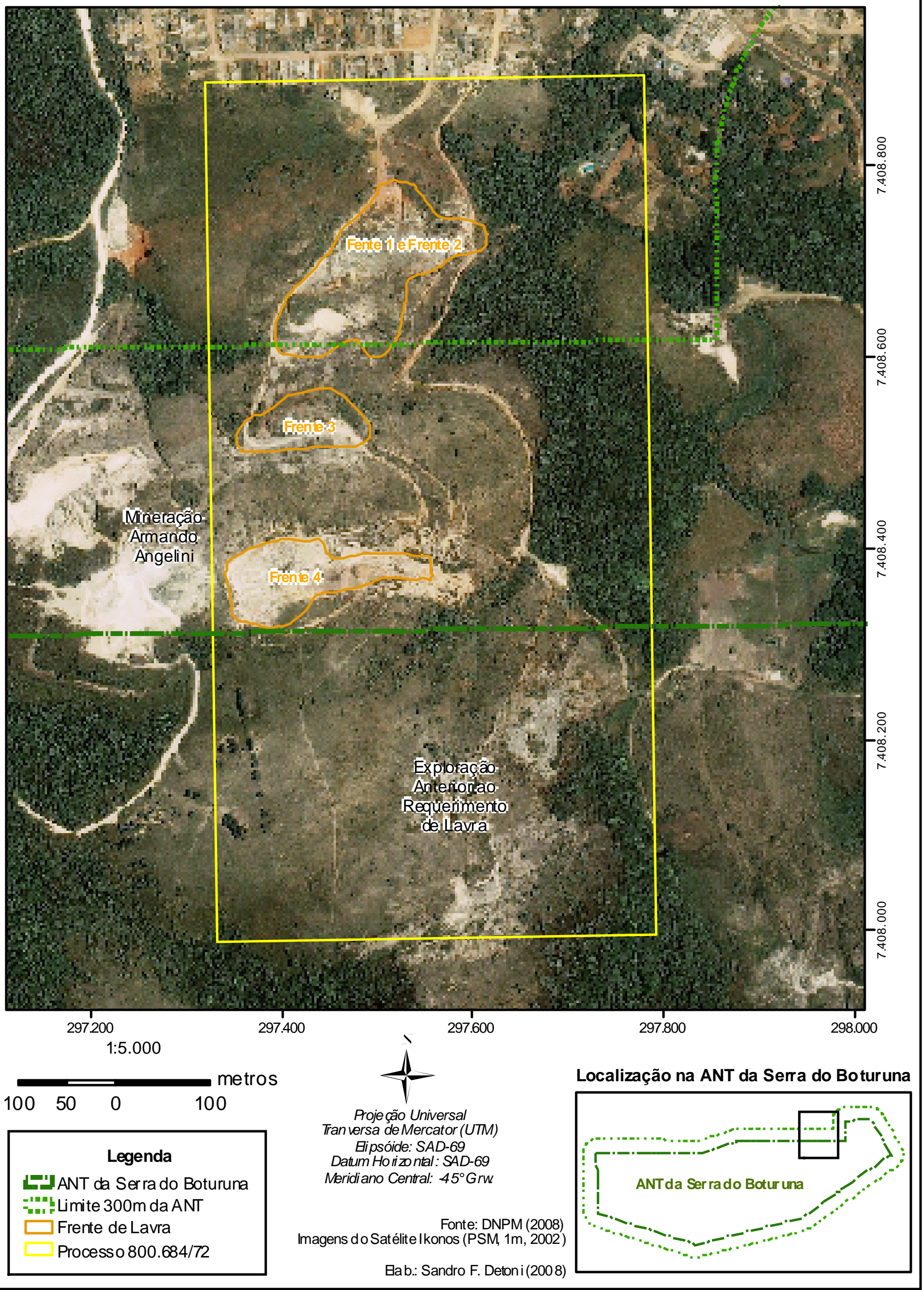


No PRAD consta que a empresa encerrou a atividade de exploração mineral. Porém, a recuperação da área possui o intuito de busca a melhor harmonia com o meio ambiente e estabelece que o uso do local, pósrecuperação, será como loteamento residencial urbano popular. A justificativa para a escolha desse uso advém do crescimento populacional do entorno.

A elaboração do PRAD seguiu o roteiro geral estabelecido pela Resolução SMA n. 18 de 23/10/1989. No qual prescrevem as seguintes etapas:

- Caracterização do empreendimento;

- Diagnóstico ambiental da área e do entorno;

- Impactos ambientais decorrentes com as respectivas medidas mitigadoras;

- Plano de Recuperação da Área pela mineradora.

A escolha da utilização futura da área como loteamento residencial urbano, possivelmente, atendeu às expectativas particulares da empresa. $O$ Mapa 15, que apresenta a localização da poligonal minerária da Minarca, demonstra que parte da área está inserida dentro do perímetro de tombamento, porém, as frentes de lavra se localizam na faixa de amortecimento de $300 \mathrm{~m}$. Interpreta-se que, antes da proposição do uso e ocupação do solo futuro para área, caberia uma consulta ao órgão que estabelece às diretrizes e às restrições de uso e ocupação, ou seja, o CONDEPHAAT.

\subsubsection{Conteúdo o PRAD}

Após uma extensiva descrição sobre as características aqüíferas da região, o Plano apresenta os principais tópicos que envolvem a elaboração do relatório de recuperação.

O método de lavra executado pela mineradora foi a céu aberto com desmonte por bancada. A primeira etapa consistiu na remoção do capeamento da jazida, ou seja, do manto de estéril. De acordo com o PRAD, a limpeza inicial da área de lavra diminuiu a relação estéril/minério. Sem o procedimento de limpeza, nas fases iniciais da mineração, essa relação pode ficar, em torno, de 1/5. No decorrer da execução da lavra, a relação passa a ser, aproximadamente, de 1/10. Com isso, a limpeza, além de melhorar as 
condições de operação, expõe a porção mineral, o que fornece um produto mineral sem rejeitos, ou seja, sem solo.

Os procedimentos de limpeza incluem a retira da camada de solo, que varia entre 0,5 e 1,5m, com a utilização um trator de esteira. Esse procedimento condiciona um sensível impacto negativo na paisagem local.

O solo é transportado para um local a $50 \mathrm{~m}$ das frentes de lavra. Para o PRAD isso facilita a sua futura utilização no processo de reconfiguração topográfica das lavras. Nesse sentido, formaram-se diversos bota-foras ao redor das frentes de lavra.

Após a retirada da camada de solo, ocorreu o desmonte do minério por meio da raspagem do leucofilito pela lâmina do trator de esteira. Efetuou-se essa raspagem numa profundidade de 10 a $15 \mathrm{~cm}$ para acumular o minério. No desmonte do minério, selecionaram-se as faixas mais claras, pois possuem maior valor comercial. Porém, escavam-se também as faixas mais avermelhadas, comercializadas com empresas especializadas na fabricação de carga para inseticidas. Convém destacar que as bancadas de leucofilitos apresentam espessuras bastante variadas ao longo de toda a exploração, isso faz com que a mineração possua, muitas vezes, um aspecto caótico. Após a extração, transportavam-se as substâncias minerais para as instalações de beneficiamento que eram localizadas a cinco quilômetros das frentes de lavras.

O corpo mineral de filito localiza-se ao norte da poligonal minerária, orienta-se no sentido nordeste, sendo intercalado por camadas de quartzo $0^{30}$ com espessuras que variam de decimétricas a métricas, cor amarela clara e grande quantidade de minerais micáceos do tipo sericita. O PRAD descreve que o minério pode ser representado por uma assembléia de minerais do tipo feldspato-potássico, quartzo (às vezes, do tipo dendrítico), sericita, muscovita e caulim, esse último constitui a massa fundamental do minério.

O solo superficial possui espessura de um a dois metros, sendo composto por serros angulosos de quartzito e quartzo. Assim, o capeamento estéril das frentes de lavra constitui-se por um solo argilo-silte-arenoso.

\footnotetext{
${ }^{30}$ Quartzito
} 
O PRAD caracterizou a vegetação local como mata mesófila decídua com as seguintes famílias bem representadas: Leguminosae, Rutaceae, Myrtaceae, Meliaceae, Rubiaceae e Lauraceae.

O entorno do empreendimento apresenta manchas isoladas de vegetação secundária em estágios médios de regeneração e grandes extensões de campos para a pecuária bovina. Destaca-se que tal atividade possui pouca expressão na região. De forma geral, o PRAD descreve que as florestas remanescentes são disjuntas e de dimensões restritas.

A vegetação primitiva nas áreas das frentes de lavra, onde se verificou o maior impacto negativo, era composta apenas por espécies de gramíneas. Assim, para a mineração, há possibilidade de reabilitação e até melhoria da qualidade de uso.

\subsubsection{Configuração atual da lavra}

As frentes de lavra encontram-se paralisadas, há muito tempo, sem pretensão da continuidade das operações, pois, de acordo com o PRAD, a área apresenta maior potencial econômico como uso habitacional.

Apesar do método de lavra prever a formação de bancadas, não se executaram as frentes de lavra dessa forma. Nota-se uma configuração de encostas com alturas, às vezes, superiores a $15 \mathrm{~m}$, o que contribui para o estabelecimento de intensos processos erosivos.

A frente 4, apresentada no Mapa 15, considerada maior área de extração, possuía, segundo o PRAD, taludes de até $21 \mathrm{~m}$ de altura e extensão total de, aproximadamente, $170 \mathrm{~m}$.

A utilização futura como loteamento residencial urbano pressupõe o estabelecimento de medidas para a reconfiguração do relevo que, para o PRAD, viabilizará economicamente a implantação desse uso.

O Plano afirmou que não houve a formação de grandes cavas como as existentes em outras minerações da região, por exemplo, a Armando Angelini. Esse fato decorre, sobretudo, porque a exploração do leucofilito ocorreu em superfície e as modificações foram nos níveis topográficos do terreno que abaixaram suas cota na proporção da espessura da mineralização. 
Com relação à avaliação dos impactos ambientais e às medidas para suprimir e minimizar os efeitos da atividade de mineração, o PRAD descreve a inexistência de impactos negativos provenientes de poeiras, de ruídos, de vibrações e da alteração das águas superficiais. A inexistência desses impactos negativos decorre, sobretudo, pela não execução da lavra. Porém, verifica-se que a abertura das cavas influencia, diretamente, no padrão de qualidade das águas superficiais, o que se constitui num impacto negativo.

O PRAD destaca que na lavra de leucofilito não houve o espalhamento de resíduos por grandes extensões da área, houve somente a remoção do capeamento de solo que fora depositado em áreas contíguas às lavras. Para o Plano, devido à natureza do material, não há possibilidade de assoreamento dos recursos hídricos superficiais, mesmo decorrente do escoamento de águas pluviais.

A recuperação topográfica das lavras constitui-se, principalmente, na eliminação dos taludes originados nas operações de lavra. Os procedimentos envolvem o rebaixamento do perfil atual do relevo do entorno das frentes de lavra que ocorrerá pela escavação mecânica. O PRAD afirmou que o material apresenta boas condições de coesão.

O aspecto paisagístico foi sem dúvida aquele cujas características sofreram maiores interferências, pois, os impactos topográficos, vegetativos e hídricos provocados pela mineração de superfície manifestaram-se mais claramente no espaço estético. (SONDA, 2004, p. 30).

A mineração reconhece que o impacto paisagístico negativo ocorreu em virtude da remoção da vegetação e do solo superficial. Tais procedimentos são necessários às fases de implantação e da operação da lavra e são intrínsecos à atividade.

As principais alterações paisagísticas são frutos da descaracterização topográfica das áreas de lavra. Contudo, para a mineradora, esse aspecto será amenizado na recuperação final da área com a execução das medidas de recuperação topográfica que incluem o nivelamento do terreno por meio da reposição de material estéril (capeamento) e o recobrimento vegetal posterior.

O PRAD destaca que não houve exposição do lenço freático, pois a execução da lavra não seccionou o nível d'água. Tampouco houve problemas relacionado ao rebaixamento de nível d'água ou desenvolvimento de escoamento superficial originado nas áreas de lavra. 


\subsubsection{Recuperação da área}

O relatório afirmou que o conceito de recuperação é controvertido, assim, estabelece-se que a mineradora utilizará os pressupostos do art. 39 do Decreto Federal n. 97.632/89. Com isso, pretende-se que o sítio degradado tenha a recuperação de acordo com o uso do solo preestabelecido, além de se buscar a estabilidade do meio ambiente.

$\mathrm{Na}$ interpretação da mineradora, a exigência legal não define o grau de recuperação requerido, dessa forma, não obriga a uma restauração às condições originais do sítio, o que, na maior parte das vezes, torna-se economicamente inviável, se não, tecnicamente impossível. Por seguinte, a legislação fixa algumas diretrizes para a recuperação da área minerada:

- A área deve ser utilizada para alguma finalidade;

- Tal finalidade deve estar de acordo com um plano preestabelecido;

- A condição final deve ser estável, ou seja, a área deve estar em equilíbrio dinâmico com o entorno.

De acordo com o Plano, tais exigências seguem as recomendações do "Grupo de trabalho de Recuperação de Áreas Degradadas Pela Mineração", constituído pela SMA. Por isso, com base nessas premissas, a primeira etapa consistiu na definição dos objetivos da recuperação por meio dos seguintes instrumentos: a legislação incidente, os planos e os projetos governamentais, a caracterização do empreendimento e a dinâmica ambiental do entorno, assim como a magnitude e a importância dos impactos ambientais previstos. No contexto mais amplo, os objetivos da recuperação devem envolver a escolha do grau de recuperação desejado e o uso futuro que se pretende para a área.

Pode-se afirmar que o Plano é contraditório com relação ao terceiro item. Conforme mencionado, a poligonal minerária está inserida dentro da ANT da Serra do Boturuna, ou seja, o equilíbrio dinâmico de entorno deveria relacionar-se com a área natural protegida. Convém observar também que as frentes de lavra, encontram-se na área envoltória de 300m da ANT da Serra do Boturuna, assim, a recuperação estaria sujeita ao discreto controle do CONDEPHAAT, o que não aconteceu. 


\subsubsection{Regularização topográfica}

A principal medida de recuperação consiste na regularização topográfica da área. Para o Plano, essa medida, que criará uma superfície única em todo o terreno, constitui-se de caráter mais urgente, tanto do ponto de vista estético, como no aspecto mitigador. Haverá um volume grande de material a ser removido, sendo assim, essa etapa requer um significativo montante de recursos financeiros e um período de tempo, relativamente, longo, para a sua execução.

O Plano descreve que a reconfiguração topográfica por meio do nivelamento do terreno ocorrerá de forma descendente. Uma das formas propostas no PRAD é o estabelecimento de curvas de nível, ou mesmo, a implantação de leiras com até um metro de altura com possíveis variações de cerca de $10 \mathrm{~m}$ de altura, esse procedimento minimizará a possibilidade de processos erosivos.

\subsubsection{Revegetação das áreas de lavra}

Após o nivelamento do terreno haverá a implantação da cobertura vegetal. Propôs-se, que as áreas com intervenção pela atividade minerária, serão imediatamente revestidas pelo plantio de capim braquiária (Brachiaria decumbens). O Plano justifica a utilização dessa espécie pelo seu caráter rústico, sendo bastante resistente ao frio, ao pisoteio e com boa tolerância à umidade, além da melhor sua adaptação da espécie em solos não férteis. $O$ PRAD também descreve a seqüência de procedimentos necessários à revegetação das áreas de lavra.

O PRAD ressalta que o estabelecimento de uma cortina vegetal é dispensável. O documento também dispõe sobre a revegetação das Áreas de Preservação Permanente (APPs) do córrego Paineira (Perobas). Contudo, destaca-se que somente uma pequena porção da APP está desprovida de vegetação.

Se o uso futuro da área não condiz com as condições de entorno, o plano de revegetação não considera a vegetação primitiva da Serra do 
Boturuna e seu entorno. Tal fato deveria ser amplamente contestado, não somente pela SMA, mas também pelo CONDEPHAAT.

\subsubsection{Cronograma}

$\mathrm{Na}$ visita de campo efetuada em maio de 2008, observou-se o não cumprimento do cronograma das atividades. A área se encontra em completo abandono e com o estabelecimento de processos erosivos. Até pouco tempo, utilizava-se a frente de lavra 1 como bota-fora. Entretanto, após fiscalização da CETESB, não se efetuou mais esse procedimento.

A mineradora pretende solicitar a alteração do PRAD com o intuito de preencher as cavas com bota-fora, sobretudo, do Rodoanel ${ }^{31}$. Destaca-se que o fácil acesso, não há muro nem cercas na propriedade, pode conduzir ao estabelecimento de loteamentos irregulares na área. O Quadro 10 apresenta o cronograma das atividades.

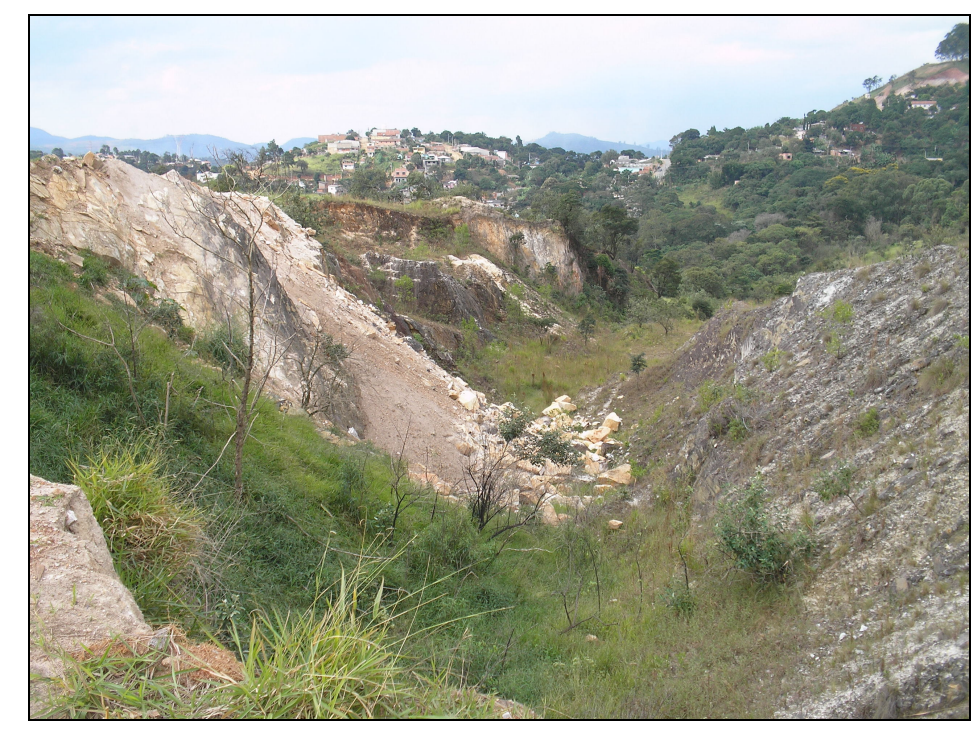

Figura 13 - Aspecto geral da frente de lavra 1, observam-se sedimentos inconsolidados que podem ser conduzidos para a rede de drenagem (Sandro F. Detoni, maio de 2008).

\footnotetext{
${ }^{31}$ Construção do Anel Viário Metropolitano
} 
Quadro 10 - Cronograma das Atividades da Recuperação da Área Degradada

\begin{tabular}{|c|c|c|}
\hline Atividade & Área & Data Limite \\
\hline Revegetação da APP & Total & Jan/2005 \\
\hline \multirow{2}{*}{$\begin{array}{c}\text { Regularização do Relevo das Áreas } \\
\text { Lavradas }\end{array}$} & Frente 4 & Jul/2005 \\
\cline { 2 - 3 } & Frente 3 & Dez/2005 \\
\cline { 2 - 3 } & Frente 1 e 2 & Jul/2006 \\
\hline \multirow{2}{*}{ Revegetação das Áreas Lavradas } & Frente 4 & Set/2005 \\
\cline { 2 - 3 } & Frente 3 & Fev/2006 \\
\cline { 2 - 3 } & Frentes 1 e 2 & Set/2007 \\
\hline Manutenção de Plantio em APP & APP & Jan/2005 \\
\hline
\end{tabular}

Fonte: SONDA (2004)

A Minarca estimou um custo para a recuperação da área degradada de, aproximadamente, $R \$ 318.000,00$, ou seja, um valor, relativamente alto. Logo, a empresa pode considerar como um investimento, por isso, a utilização da área como loteamento urbano.

O Parecer Técnico CPRN/DAIA n. 058/2005 aprovou O PRAD apresentado pela Minarca. Apesar da aprovação, o parecer estabeleceu que para concluir os procedimentos de recuperação, a empresa deverá atender às seguintes exigências:

- Apresentar à CETESB e ao DEPRN o projeto executivo de terraplenagem e drenagem dos dois níveis topográficos que correspondem às frentes 1 , 2 e 3 e outro especial para a frente 4;

- Apresentar à CETESB e ao DEPRN o plano de controle de erosão que deve constar o confinamento do escoamento das águas pluviais ao interior das cavas (bacias de decantação);

- Apresentar ao DEPRN o projeto de recomposição florística das APPs;

- Apresentar à CETESB e ao DEPRN o projeto de recuperação das áreas constituídas pelas cavas abandonadas situadas ao sul da denominada "área de mineração";

- Regularizar no DNPM a situação da cava em atividade a oeste da frente 4 que extrapola a poligonal minerária e apresentar documento de comprovação à CETESB e ao DEPRN;

- Regularizar na CETESB e no DEPRN a situação da cava em atividade a oeste da frente 4, parcialmente, inserida na poligonal em análise, 
considerada a continuidade de lavra e a recuperação concomitante à atividade.

A SMA contratou a FIPE para a emissão de um parecer técnico sobre a recuperação da área degradada, que foi entregue em dezembro de 2004.

O documento confirma que a frente 4 é a de maior dimensão na propriedade.

Entretanto, a terraplenagem condicionará um impacto maior do que o já existente, considerando a elevada declividade da encosta dentre as frentes 3 e 4 e a necessidade de uma movimentação exagerada de solo. Desta forma é sugerida que seja executadas uma terraplenagem envolvendo apenas as frentes 1,2 e 3 , que se encontram situadas em uma área de pequena inclinação e outra movimentação de solo específica para a frente 4 , que se situa em outro patamar desta mesma encosta. Isso implicaria em menor movimentação de solo na área e menor intervenção na vegetação existente no local, em estágio inicial de desenvolvimento de cerrado (lato sensu). (PARECER TÉCNICO FIPE, p. 03 in: SONDA, 2004 p. 52).

Para os técnicos, o PRAD não considerou a área ao sul da frente 4 e a cava em lavra a oeste da mesma frente. Ressalta-se que essas áreas fazem limite com o perímetro de tombamento. Apesar dessas ponderações, a consultoria particular também aprovou o PRAD com o acréscimo de algumas exigências, entre as quais, a apresentação à CETESB e ao DEPRN do projeto executivo de terraplenagem e drenagem em dois níveis, um para as frentes 1 , 2 e 3 e outro para a frente 4.

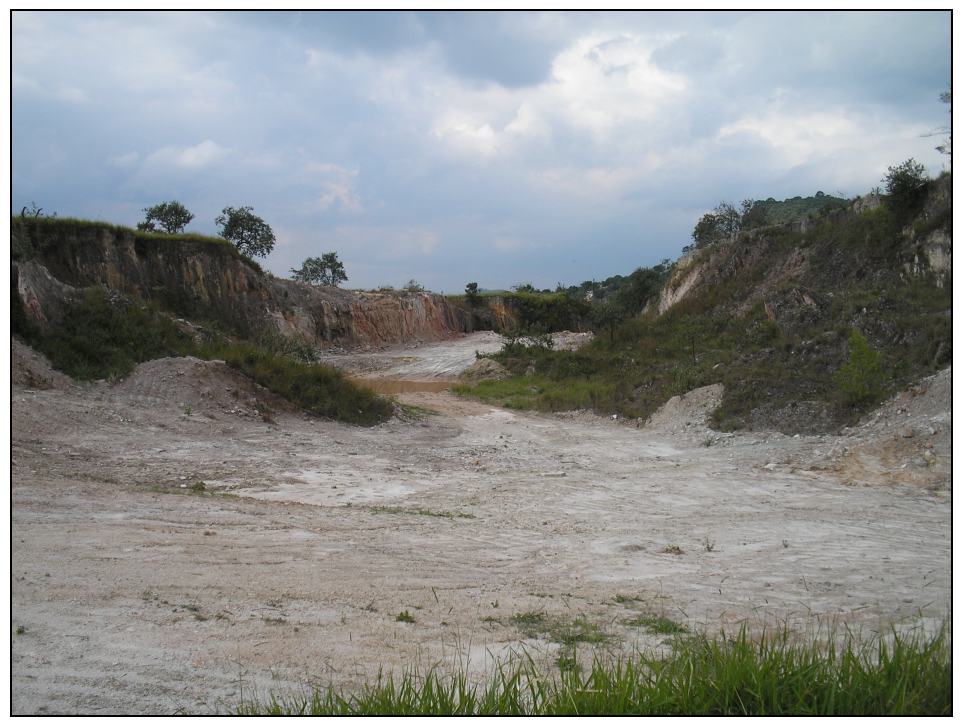

Figura 14 - Frente de lavra 3: as propostas de reconfiguração topográfica não foram efetuadas (Sandro F. Detoni, maio de 2008). 
A Minarca, em carta protocolada na SMA em abril de 2005, afirmou que as áreas sul e oeste da poligonal de pesquisa foram explorados por terceiros, ou seja, antes da mineração conseguir a portaria de lavra. Porém, com relação à área oeste da frente 4 , a pesquisa de campo e a imagem de satélite demonstraram que a exploração mineral é efetuada pela Mineradora Armando Angelini e está fora da poligonal minerária requerida por essa mineradora.

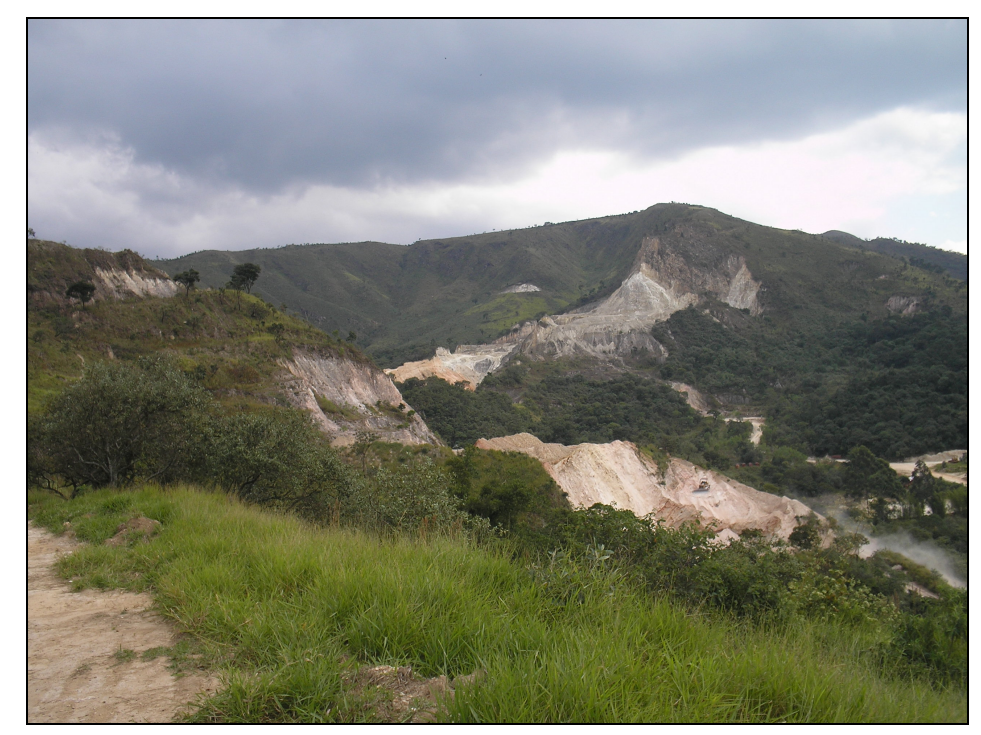

Figura 15 - Limite oeste da poligonal minerária da Minarca: frentes de lavras exploradas pela Mineração Armando Angelini (Sandro F. Detoni, maio de 2008)

Para a Minarca, as bacias de decantação não necessitam ser implantadas, pois a própria CETESB informa que há oito anos não há exploração da lavra, por isso, os técnicos da Minarca atestam que nesse tempo não houve erosão devido à estabilidade do minério filio e quartzito.

Em resumo, é possível afirmar que a SMA analisou os aspectos técnicos da recuperação das frentes de lavra. No entanto, não se considerou que, do ponto de vista legal, a poligonal minerária e as frentes de lavras se encontram, respectivamente, na ANT da Serra do Boturuna e sua faixa de amortecimento de $300 \mathrm{~m}$. O PRAD não faz nenhuma referência a esse aspecto e a SMA não formalizou um pedido de enquadramento da mineração junto ao CONDEPHAAT. É de fundamental importância o CONDEPHAAT participasse da recuperação e da proposição da utilização futura para a área. 


\subsection{MINERAÇÃO ARGAMASSAS QUARTZOLIT LTDA.}

\subsubsection{Histórico da mineração}

A indústria Argamassas Quartzolit Ltda. foi fundada em 1937 com a aquisição Trituradora de Minérios Helvetia, assim, sua atividade inicial relacionava-se à trituração de matérias-primas minerais, principalmente, o quartzo e o quartzito. A partir daí, a Quartzolit passou a fornecer quartzo moído para a Sociedade Comercial S. A. que, na época, utilizava a substância mineral no revestimento do Viaduto do Chá, na Capital Paulista.

O fornecimento de quartzo moído para a Sociedade Comercial impulsionou a criação de um tipo de argamassa industrializada. Com isso, a Quartzolit passou a comercializar a argamassa pronta e embalada em sacos e estabeleceu seu novo foco voltado para a produção argamassas e a posterior comercialização e industrialização de massa fina.

$\mathrm{Na}$ década de 1970, a Quartzolit lançou a argamassa colante cimentcola, utilizada no assentamento de cerâmicas, o que proporcionou um significativo crescimento e a construção outra fábrica, em Jandira, São Paulo. Porém, a produção de argamassas ainda dependia de diversas fontes, sendo que, a princípio, a matéria-prima era adquirida, principalmente, de pequenos produtores da região.

A irregularidade no fornecimento das substâncias minerais para a produção de argamassas fez com que a empresa buscasse uma mina própria com o intuito de garantir um fornecimento regular e determinados padrões de controle de qualidade aos produtos industrializados. A proximidade da Serra do Boturuna da fábrica da Quartzolit estimulou a compra da propriedade rural com reservas de quartzito, em Pirapora do Bom Jesus, denominado Sítio Itaqueri. Destaca-se que seus proprietários já o haviam arrendado para uma empresa denominada Companhia Brasileira de Mineração (COBRAMI), que explorou o quartzito do local. Dessa forma, a área possuía frentes lavras abandonadas e com o estabelecimento de problemas ambientais relacionados às técnicas de mineração.

A compra do terreno pela Quartzolit foi acompanha pelos requerimentos de autorização de pesquisa de quartzito, junto ao DNPM. Esses requerimentos 
correspondem aos processos $820.457 / 79$ e $820.561 / 79$, representados no Mapa 16.

Convém destacar que, na época, em virtude da aplicação do PDM da RMSP, a EMPLASA emitiu pareceres favoráveis à realização da pesquisa mineral de quartzito no sítio. O PDM de Pirapora do Bom Jesus de 1982 analisou de forma preliminar os casos de exploração mineral existentes no município com o intuito de averiguar os conflitos existentes entre as frentes de lavra e as propostas de diretrizes para a atividade mineral. Apesar da poligonal minerária do processo DNPM n. 820.457/79 se referir ao alvará de pesquisa, a equipe técnica constatou a existência de operação de lavra de grande porte na propriedade da Quartzolit. Assim, o mapa de diretrizes para a atividade mineral estabelecia que a mineração, naquela área, seria "permitida com restrições técnicas", logo, o Plano propôs as seguintes providências:

- Oficiar o DNPM com o intuito de solicitar a suspensão da validade da guia de utilização concedida;

- Oficiar o DNPM, a CETESB e a SNM com o intuito de solicitar providências para a suspensão imediata da lavra.

Solicitou-se ainda que o Plano de Aproveitamento Econômico (PAE) da lavra apresentasse os procedimentos operacionais relacionados às restrições especificas da região.

Com relação à poligonal minerária referente ao processo DNPM $\mathrm{n}$. $820.561 / 79$, o Plano descreve que a região possuía características geomorfológicas que implicavam numa maior vulnerabilidade às interferências ligadas aos processos e uso do solo e recomendou:

- Estudos detalhado sobre a estabilidade dos taludes;

- Local de deposição do material estéril, com remoção prévia da cobertura vegetal;

- Plano de recuperação e uso explícito após a lavra.

Apesar do caráter inovador, essas medidas de caráter restritivo e preventivo não foram aplicadas, mesmo porque, oficialmente, a mineradora nunca explorou a lavra e o plano nunca se constituiu na forma de lei.

Outro aspecto importante se relaciona às frentes lavas abandonadas localizadas próximo à propriedade da Quartzolit. Segundo o EIA-RIMA a 
mineradora, essas frentes correspondiam ao processo DNPM n. 820.179/79 e abrangiam as frentes de lavradas e abandonadas pelas minerações Dois Irmãos e Mar Paulista. Tais frentes de lavras estão, respectivamente, a oeste e leste das poligonais da Quartzolit e, atualmente, não apresentam registros de processos minerários no DNPM.

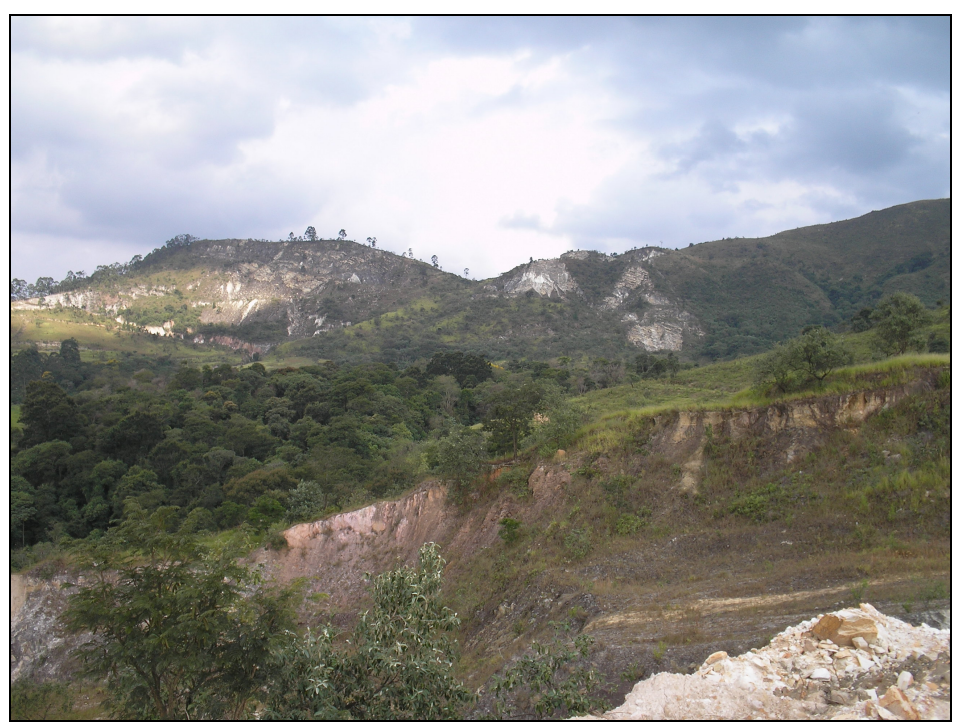

Figura 16 - ANT da Serra do Boturuna: frentes de lavra na propriedade da Quartzolit (Processo DNPM n. 820.457/1979), à esquerda; frentes de lavras abandonadas da antiga Mineração Mar Paulista, à direita (Sandro F. Detoni, maio de 2008)

O Mapa 16, que representa as poligonais minerárias requeridas pela Empresa Argamassas Quartzolit, também demonstram a localização das frentes de lavra da antiga Mineração Dois Irmãos e da Mineração Mar Paulista. A área da poligonal 820.457/79, que passou por processo de exploração do quartzito, apresenta-se no centro dessas frentes lavras exploradas e abandonadas sem que houvesse a recuperação da área degradada.

As técnicas empregadas pela Mineração Dois Irmãos para a extração do quartzito geraram um importante impacto negativo na paisagem demonstrado, principalmente, pela desconfiguração topográfica da Serra do Boturuna. Segundo informações dos funcionários da Prefeitura de Pirapora do Bom Jesus, a degradação da Serra do Boturuna, naquele setor, constituiu-se num dos principais argumentos favoráveis ao pedido de tombamento junto ao CONDEPHAAT. 
As Figuras 17, 18 e 19 demonstram o aspecto da Mineração Dois Irmãos em 1982 e a configuração atual da área. É importante destacar que o PDM de Santana de Parnaíba descreveu os impactos negativos das minerações de quartzito na década de 1980:

Nas áreas de mineração de quartzito os problemas observados foram quanto a disposição de rejeitos, colocados caoticamente ao lado de córregos; uso de explosivos por pessoas inabilitadas, inexistência de paiol para os explosivos; interferência entre mineradores causando um sub-aproveitamento (sic) da jazida; lavra mal conduzida, com altos taludes, colocando em risco a segurança dos funcionários. Ao lado disso pode-se ressaltar ainda, que a maioria das minerações não constam com qualquer processo junto ao DNPM. (EMPLASA, 1985, p. 34 e 35).

Assim, a não utilização de técnicas adequadas de extração mineral e a ilegalidade do setor contribuíram para o forte impacto paisagístico negativo em muitos setores da Serra do Boturuna. É possível notar que o abandono da área propiciou uma nova condição de equilíbrio e, mesmo sem a realização dos procedimentos para a recuperação da degradação ambiental da área, ocorreu uma incipiente recomposição da cobertura vegetal. Porém, constata-se que as técnicas de extração mineral empregadas e as características do ambiente contribuíram para a difícil recuperação natural da área.

Conforme mencionado, não há registro da Mineração Dois Irmãos no DNPM. A Mineração Mar Paulista, atualmente, não efetua atividade extração mineral. Essa empresa, fundada em 1968, denomina-se Indústria de Revestimentos Mar Paulista e possui sede na Capital Paulista. Seu foco principal consiste na industrialização e na comercialização de revestimentos finos e massas primárias. A matéria-prima para a sua indústria advém, entre outros fornecedores, da Mineração Armando Angelini. 


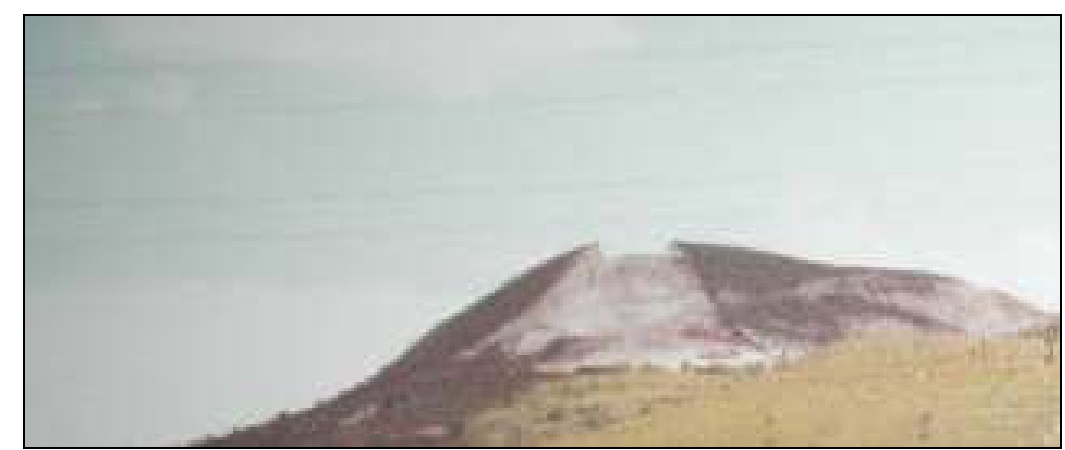

Figura 17 - Mineração Dois Irmãos em 1982 (Processo de tombamento da Serra do Boturuna - CONDEPHAAT n. 22328/82)

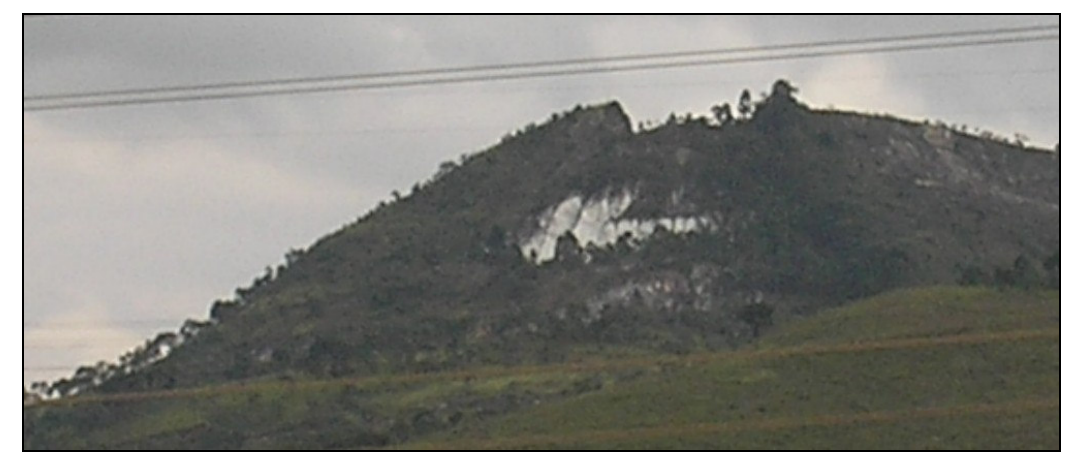

Figura 18 - Aspecto atual da antiga Mineração Dois Irmãos (Sandro F. Detoni, maio de 2008)

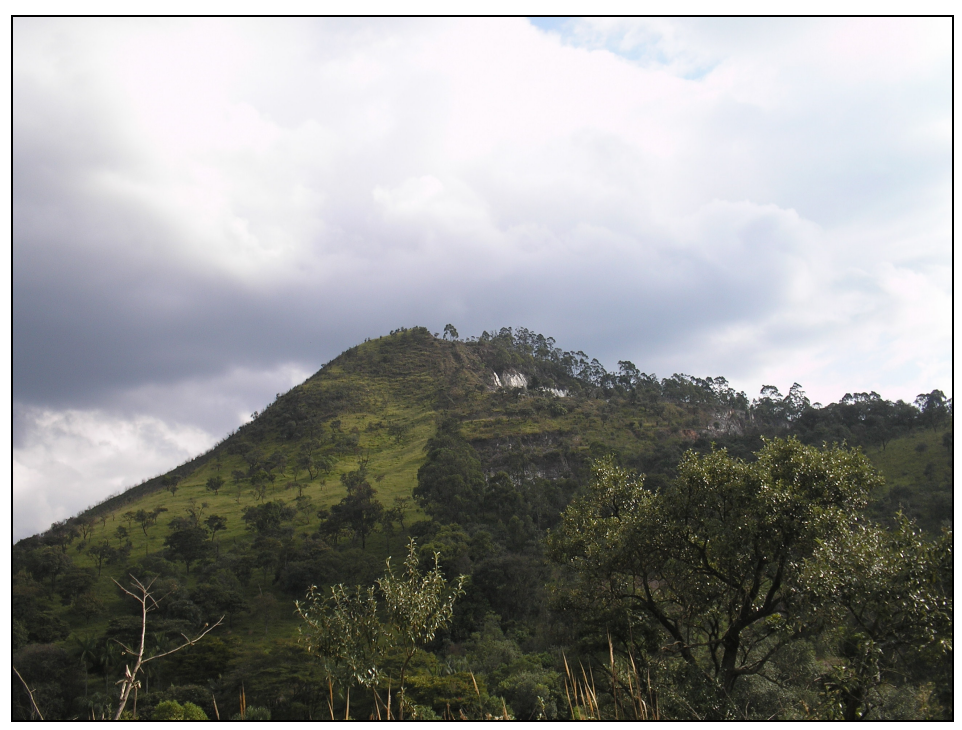

Figura 19 - Outro ângulo do aspecto atual da antiga Mineração Dois Irmãos (Sandro F. Detoni, maio de 2008)

Com relação às frentes de lavras da Quartzolit, em 1980, após a concessão dos alvarás de pesquisa e da autorização para o funcionamento como empresa de mineração, a Quartzolit obteve a guia de utilização, junto ao 
DNPM, do processo n. 820.457/79. A mineradora passou a extrair quartzito no sítio e iniciou o trabalho de ordenamento da frente de lavra por meio da formação de bancadas com o intuito de se evitar desmoronamentos em virtude, segundo a mineradora, da lavra indiscriminada anteriormente realizada pela COBRAMI.

De acordo com EIA-RIMA, a empresa também construiu duas barragens no ribeirão Perobas para a retenção do material erodido das frentes de lavra, além do reflorestamento em parte do sítio com eucaliptos. O relatório integral de pesquisa das duas áreas foi apresentado ao DNPM em 1981 e foi exarado um parecer técnico favorável à aprovação do relatório final de pesquisa pelo DNPM.

O tombamento da Serra do Boturuna, em 1983, constitui-se na aplicação de um novo instrumento jurídico ambiental para a Quartzolit, o que poderia caracterizar maiores dificuldades para a exploração mineral na região. Mesmo assim, em 1989, a empresa efetuou o protocolo no DNPM do requerimento de autorização de pesquisa de quartzito referente ao processo 820.059/89 que abrange o restante do sítio. O objetivo da empresa seria garantir área suficiente para a exploração de quartzito. Requereu-se também o aproveitamento comercial da areia retirada da bacia de sedimentos e provenientes dos trabalhos de desassoreamento do curso d'água existente na propriedade. Destaca-se que a poligonal minerária 820.059/89 ainda se encontra na fase de requerimento de pesquisa.

Para subsidiar a decisão de levar adiante ou não os processos no DNPM, em função do tombamento da Serra do Boturuna, a QUARTZOLIT iniciou uma série de consultas aos órgãos envolvidos no processo de licenciamento para poder avaliar a probabilidade de obtenção das licenças necessárias em se tratando de área tombada. (JAAKKO, 1989, p. 10).

Em 1989, a Quartzolit encaminhou ao CONDEPHAAT um pedido de enquadramento da atividade de exploração mineral. O órgão condicionou o atendimento do pedido ao cumprimento das condições impostas pelo art. $2^{\circ}$., inciso IX da Resolução CONAMA 1/1986, assim, o parecer do CONDEPHAAT dependia da análise técnica do impacto ambiental resultante da exploração da lavra de quartzito. Por isso, diferente das outras empresas de mineração legalizadas na Serra do Boturuna, a Quartzolit elaborou um EIA-RIMA, em virtude da nova jurisprudência imposta. Por isso, o PRAD da Quartzolit fez 
parte relatório de impacto ambiental da lavra de quartzito. Esse relatório também foi composto pelo PAE da lavra e pelo PL. O documento foi elaborado pela consultoria Jaakko Pöyry Engenharia Ltda. e apresentado, conjuntamente à SMA e ao CONDEPHAAT.

Segundo a mineradora, com o intuito de adiantar os procedimentos para a obtenção das licenças de instalação e de funcionamento, a empresa conduziu a elaboração do EIA-RIMA resultante de lavra de quartzito friável na Serra do Boturuna.

A situação da mineração, quando da elaboração do EIA-RIMA, era a seguinte: os morros, onde se localizavam as poligonais minerárias $n$. 820.457/79 e n. 820.561/79 passaram por extração mineral sem critérios técnicos adequados e, na ocasião, as lavras estavam paralisadas; havia uma grande quantidade de areia retirada na barragem construída no ribeirão Perobas; essa barragem se encontrava fora do perímetro de tombamento e dentro da faixa de amortecimento de $300 \mathrm{~m}$; a empresa retirava o material da bacia de decantação com o objetivo de aproveitamento em sua indústria; a retirada de material da bacia também contribuía, segundo o EIA-RIMA, para o desassoreamento do ribeirão Perobas, pois evitava o extravasamento de areia sobre a barragem e o conseqüente assoreamento a jusante.

O processo de regularização da área fez com que a Quartzolit não explorasse suas lavras de quartzito na Serra. O relatório descreve que, no período de regularização da mineração, adquiriu-se o quartzito da mineradora Armando Angelini.

Apesar das poligonais abrangerem uma área de 21,4 ha, para o EIARIMA, se as lavras fossem efetivamente exploradas, no final da vida útil da jazida, a configuração final da cava ocuparia uma área de 13,93 ha. Esse tamanho corresponde a $27 \%$ da propriedade do Sítio Itaqueri e 65\% da área das poligonais. O documento também destaca que a estrutura de apoio à mineração abrangeria uma área de $360 \mathrm{~m}^{2}$.

O PL descreveu uma escala de produção da ordem de 120.000 t/ano de quartzito. Os cálculos estimados de cubagem da reserva lavrável foram da ordem de 1,4 milhões de toneladas de quartzito friável. Dessa forma, de acordo com a escala de produção, a vida útil da reserva seria de 12 anos. 
A extração da camada superficial de quartzito friável ocorreria com a utilização de trator, assim, não se exploraria a rocha compacta, sem a necessidade do uso de explosivos na frente de lavra. A camada superficial de areia apresentava, no local, uma profundidade média de cinco metros. Para a mineradora, optou-se pela exploração somente dessa camada, pois o objetivo da lavra seria de fornecer matéria-prima somente para a indústria de argamassa.

A argamassa é amplamente utilizada na construção civil e seu processo de fabricação inclui o quartzito, que é misturado a outros insumos, como cal hidratada, cimento e aditivos químicos, que proporcionam plasticidade e aderência ao produto após sua ativação com a adição de água.

O EIA-RIMA destaca que, devido à falta de regularidade no fornecimento de matéria-prima, a fábrica de argamassas operava abaixo da sua capacidade. De acordo com a empresa, o quartzito poderia ser substituído, em princípio, por areias de planícies fluviais ou por pedras moídas e classificadas. Contudo, a aquisição desses materiais não estava atrelada aos padrões de controle de qualidade exigido para a fabricação de argamassas, logo, poderia conter impurezas prejudiciais ou grãos de tamanhos inadequados, o que influenciaria na resistência da argamassa. A pedra moída seria a alternativa viável, em razão da escolha do tipo de rocha isenta de impurezas. Porém, a empresa estimou que custo de extração do material fosse 15 vezes superior ao do quartzito friável.

A Argamassas Quartzolit Ltda. passou a fazer parte do Grupo Francês Saint-Gobain, em 1997, e sua denominação foi alterada para a Saint-Gobain Argamassas Quartzolit Ltda. Esse Grupo também inclui uma das maiores empresas de mineração do Estado de São Paulo, a Mineração Jundu Ltda. que possui minerações de areia em municípios localizados na região da Formação Botucatu, no Interior do Estado de São Paulo. No entanto, a matéria-prima para a produção de argamassas do tipo cimentcola passa a ser fornecida por essas minerações e, apesar da elaboração do EIA-RIMA, a Saint-Gobain Argamassas Quartzolit, efetivamente, nunca explorou a escala de produção programada para as lavras nas poligonais requeridas.

A disponibilidade de matéria-prima fornecida por outras fontes fez com que, em 2007, a Saint-Gobain Argamassas Quartzolit cedesse os direitos de 
lavra para a empresa Hipermix Concreto, especializada na preparação de massa de concreto e argamassa para construção. Elaborou-se um contrato de instrumento particular de cessão total de direitos minerários para as minas de quartzito e de filito, que correspondem as poligonais 820.457/79, 820.561/79 e 820.059/89, pertencentes à Saint-Gobain.

De acordo com a Hipermix, a mineração possui toda a documentação aprovada nos órgãos ambientais competentes, inclusive a Licença de Instalação junto à CETESB. O contrato de cessão total de direitos minerários descreve, em sua cláusula terceira, sobre a situação da mina. A cláusula confirma a aprovação do EIA-RIMA da atividade de lavra de quartzito pela SMA por meio do Parecer Técnico CPLA/DAIA n. 002/95 e a aprovação pelo CONSEMA, segundo o Parecer Técnico n. 11/99-AT/GEOL/DRMSP/DEPRN. Porém, a aprovação foi condicionada à adoção de medidas de controle do empreendimento. Convém destacar que o contrato de cessão total de direitos minerários transfere a responsabilidade da elaboração de um novo PRAD para a Hipermix Concreto.

A responsabilidade perante os órgãos ambientais, da implantação e operação da mina de quartzito e filito será transferida integralmente a CESSIONÁRIA que deverá implantar o Plano de Recuperação de Áreas Degradadas da mina de quartzito e filito. (Contrato de Cessão Total de Direitos Minerários in: JAAKKO, 1989).

O valor negociado pela cessão total dos direitos minerários, que incluiu também o licenciamento ambiental da mina de quartzito, foi de $R \$$ 1.178.000,00. Porém, a cláusula quinta do contrato de cessão aponta uma estimativa de custo para a recuperação das áreas degradas é de $R \$$ $828.000,00$, ou seja, por volta de $70 \%$ do valor da cessão. Ainda segundo essa cláusula, a cessionária deverá implantar o PRAD do empreendimento. Com isso, o preço total de venda dos direitos minerários e da propriedade foi de $R \$$ $570.000,00$.

Destaca-se também a cláusula 7ª.., que dispõe sobre as responsabilidades da cessionária, confirma que fica a cargo exclusivo da cessionária a implantação e a operação da mina de quartzito e de filito, bem como a recuperação das áreas degradadas.

O contrato de cessão total de direitos minerários apresenta como responsável legal o Senhor Márcio Locatelli. Destaca-se que o responsável legal protocolizou, em 2007, um requerimento de pesquisa de filito no entorno 
das poligonais adquiridas junto à Saint-Gobain Quartzolit, cujo processo no DNPM é o de n. 820.685/2007.

Nenhuma das cláusulas do contrato de cessão de direitos minerários menciona o fato da propriedade se localizar, em parte, numa área tombada pelo CONDEPHAAT, ou seja, do ponto de vista legal, a região possui restrições de uso e de ocupação do solo. Com relação ao posicionamento da SMA, solicitou-se uma declaração de cumprimento do PRAD, do EIA-RIMA e das medidas mitigadoras da atividade de lavra.

A Hipermix planeja o inicio de suas operações de lavra em 2009. De acordo com Locatelli (2008), o material explorado será utilizado na fabricação de concreto e argamassas na RMSP. Num primeiro momento, a mineradora manterá o mesmo PL apresentado pela Quartzolit. No entanto, deve-se efetuar um novo estudo de viabilidade para a exploração do quartzito compacto, encontrado abaixo das camadas de quartzito friável, assim, há perspectiva de aumento das reservas lavráveis. Para o proprietário, se houver viabilidade de exploração, será elaborado um novo EIA-RIMA.

Ainda de acordo com Locatelli (2008), a empresa acredita no potencial mineral da região. Embora haja grandes empecilhos ambientais, a mineradora pretende encontrar soluções para viabilizar uma mina bem maior do que a aprovada atualmente. O minerador pondera sobre o fato da Serra do Boturuna ser tombada pelo CONDEPHAAT, porém, afirmou-se que, apesar do tombamento, na área onde a empresa possui o Decreto de Lavra não se aplicam as diretrizes do tombamento, ou seja, para a empresa, do ponto de vista legal, as áreas das poligonais constituem-se uma exceção à aplicação das normas do tombamento.

Com relação ao novo requerimento de pesquisa, a mineradora afirmou que ainda não possui um posicionamento do CONDEPHAAT. O requerimento corresponde, segundo Locatelli (2008), à área de expansão da mineração, cuja propriedade pertence a terceiros. No entanto, a mineradora não tem conhecimento de quem sejam os proprietários.

A mineradora pretende concentrar seus esforços para aumentar a área de lavra a céu aberto ou mesmo de uma lavra subterrânea. A viabilização de uma lavra subterrânea condiciona-se, segundo a empresa, à tendência de alta 
dos agregados empregados na construção civil, o que se constitui num atrativo para a mineradora, principalmente, pela proximidade do mercado consumidor.

Para Locatelli (2008), o produto será beneficiando na propriedade da empresa e consumido pela própria Hipermix na fabricação de concreto e argamassas.

Como o novo EIA-RIMA da Hipermix Concreto não foi elaborado, analisou-se o EIA-RIMA, elaborado em 1989, pela Argamassas Quartzolit, pois, possivelmente, esse documento servirá de base para a elaboração das propostas de recuperação no empreendimento.

\subsubsection{EIA-RIMA}

O EIA-RIMA previa a recuperação da área de mineração, prioritariamente, na poligonal de tombamento.

A Quartzolit ressaltou no documento que existiam alternativas para a exploração do quartzito em outros locais e, na época da aquisição da propriedade, buscavam-se alternativas para o fornecimento da matéria-prima para a sua indústria. No entanto, o tempo necessário para que a empresa encontrasse um material adequado e os trâmites burocráticos para a aquisição das licenças necessária para a execução da lavra, em escala compatível com suas necessidades, tornavam o empreendimento na Serra do Boturuna mais atrativo. "Por isso, o objetivo atual é explorar o quartzito friável ordenadamente, de forma a permitir a posterior recuperação da área e concomitantemente, buscar novas fontes de matéria-prima." (JAAKKO, 1989, p. 38).

O PAE descreve as alternativas tecnológicas de lavra e a forma de beneficiamento físico do material. Dessa forma, ressalta-se que seriam lavradas somente as camadas superficiais do quartzito.

Considerando que os processos $820.457 / 79$ e $820.561 / 79$ interferem com o polígono de tombamento da Serra do Boturuna e que, após consultado, o próprio CONDEPHAAT manifestou seu desinteresse em abandonar a área na condição atual, o projeto de lavra prevê a recuperação da área minerada, de acordo com o que estabelece a legislação em vigor, lavrando apenas o horizonte de quartzito friável.(JAAKKO, 1989, p. 39).

Segundo o documento, a escolha do método de lavra considerou a posição e a forma do corpo da jazida, a espessura média do horizonte alterado, 
as suas características de escavação da lavra, a topografia local, o grau de mecanização desejado para as operações de lavra, a escala de produção requerida e a recuperação das áreas de exploração. Por isso, a mineradora optou pela lavra em meia encosta, executada por escavadeira mecânica.

Com relação à produção de rejeitos e o estabelecimento de processos erosivos, o EIA-RIMA, destaca que, na época, a propriedade encontrava-se desmatada e com o embasamento de rocha quartzítica aflorante em, praticamente, toda a área. Com isso, não haveria estéril a remover ou a estocar. As áreas com intercalações de filitos, ou seja, com possibilidade da alta produção de rejeitos, seriam isoladas.

Os cortes que limitam a cava deverão ser protegidos contra a erosão à medida que foram assumindo suas posições finais, através da revegetação prevista no plano de recuperação que auxiliará também na manutenção da estabilidade dos taludes finais. (JAAKKO, 1989, p. 49).

Outra característica do PL refere-se ao contato entre o horizonte alterado e a rocha quartzítica. O Plano afirmou que esse contato não é regular, por isso, os equipamentos de lavra não extrairiam esse horizonte por completo. Isso faria com que a cava, na configuração final, apresentasse um pico com afloramento de rocha compacta circundada por rochas decompostas. Logo, esse material estaria sujeito aos processos erosivos, assim, tornava-se importante a manutenção da barragem do ribeirão Perobas, pois, nos períodos de chuva, haveria carreamento de areia dos setores ainda desprotegidos.

O planejamento de lavra também buscava ajustar as operações à condição econômica de exploração ótima. Isso se dava pelo controle dos limites minério/estéril nos contatos entre quartzito e filito. Com esse controle, segundo o documento, seria possível aperfeiçoar a recuperação da lavra e minimizar as diluições. Entre outras condições, tornava-se possível minimizar o tempo de deslocamento dos equipamentos, o tempo dos ciclos e tempo de manutenção dos espaços de operação.

O PL descreve a seguinte seqüência de exploração das frentes de lavra: um, quatro, sete e 12 anos. A exploração das lavras ocorreria de forma descendente entre as cotas 1.000 e 795m, a sudeste da área e o estabelecimento de bancadas de cinco metros. Previa-se a abertura de quatro cavas, o que incluiria as cavas exploradas anteriormente. Após a sua exaustão, a configuração do pit de lavra resultaria num formato grosseiramente retangular 
com dimensões aproximadas de 500m na direção norte-sul e 320m leste-oeste. Com base nas observações em cortes existentes, a equipe técnica estabeleceu que, na situação final do pit, os bancos de encosto teriam, no máximo, $10 \mathrm{~m}$ de altura. Os taludes teriam inclinação de horizontal/vertical na proporção de 2/3. Estimou-se a geometria da frente de lavra em função da friabilidade do minério, pois se fossem estabelecidas alturas maiores, as áreas estariam sujeitas a escorregamentos durante ou após a execução da frente de lavra.

Numa análise superficial proposta pelo EIA-RIMA, os solos resultantes da alteração do quartzito ou a própria alteração da rocha não apresentam problemas relacionados à estabilidade, sobretudo, por suas características físicas. No entanto, conforme mencionado, esses solos são suscetíveis à erosão pelas águas pluviais, por essa razão o EIA-RIMA propôs que os taludes seriam recobertos por proteção vegetal, assim que se estabelecessem suas posições finais de lavra.

O EIA-RIMA analisou o impacto da mineração por meio do estabelecimento de quatro áreas de áreas de influência do empreendimento minerário. Descreveram-se, então, as esferas de influência de uma mineração com a ponderação sobre os impactos ambientais e sócio-econômicos direitos e indiretos frutos do empreendimento.

\subsection{3 Área de influência A}

Para o EIA-RIMA, o principal impacto ambiental da mineração dentro do empreendimento relaciona-se à erosão do quartzito friável que conduzirá o assoreamento dos cursos d'água a jusante das lavras. Incluiu-se tal impacto como pertencente à área de influência $A$ que abrangeu as áreas a serem lavradas e a rede drenagem até o reservatório de Pirapora. Por isso, o documento apresenta a caracterização física da área do empreendimento com o intuito de descrever os impactos ambientais negativos causados pela mineração quanto à magnitude, à importância, à duração e à sua reversibilidade.

Quantificaram-se os impactos diretos, que se relacionam à erosão do quartzito friável, por meio da equação universal de perdas de solo. Os impactos 
indiretos condicionam-se ao assoreamento dos cursos d'água e a influência sobre a operação do reservatório de Pirapora.

Atualmente, a vertente norte do Morro do Boturuna, dentro da propriedade da QUARTZOLIT, acha-se profundamente alterada em relação à sua feição original, pouco restando do capeamento de solo, a não ser uma pequena faixa próxima aos limites da propriedade. Em muitos pontos, houve escorregamentos, formando pilhas de material que já sofre seleção pelo processo de deslizamento, variando a granulometria do material do topo em relação ao da base. O grau de intemperismo e, conseqüentemente, a friabilidade da rocha aflorante, também varia em toda a área. Desta forma, torna-se difícil a avaliação do potencial de erosão da área. (JAAKKO, 1989, p. 205).

O diagnóstico do impacto das lavras existentes no Sítio Itaqueri sobre o assoreamento do reservatório de Pirapora decorre de uma notificação emitida pela antiga operadora do reservatório, a Eletropaulo, em 1988.

Assim, o relatório incluiu o assoreamento do reservatório como um impacto direito da atividade de lavra. A proposta para a reversão do quadro erosivo envolve o plantio de gramíneas, conforme o avanço das frentes de lavra. $\mathrm{Na}$ caracterização desse impacto, descreve-se que o quartzito friável será quase totalmente retirado, assim, restará pouco material sujeito à erosão e a revegetação da área dificultará a erosão do material remanescente.

De acordo com o EIA-RIMA, a manutenção da situação atual resulta num impacto de erosão e de assoreamento de grande magnitude. No entanto, parte desse impacto apresentará mitigação com a construção das barragens de contenção de sólidos, o que o torna um impacto irreversível no que diz respeito à erosão do morro e de reversibilidade de alto custo para o desassoreamento do reservatório de Pirapora.

A conclusão que se chega, em relação à área de influência "A", é que o impacto ambiental negativo na lavra é semelhante ao da manutenção da situação atual, mas é de menor duração, o que depõe favoravelmente à realização da lavra. (JAAKKO, 1989, p. 237).

\subsection{4 Área de influência $B$}

Considerou-se a área de influência $\mathrm{B}$, o provável impacto sócioeconômico da lavra de quartzito no município de Pirapora do Bom Jesus. Dessa forma, o relatório concluiu que a implantação da lavra é compatível com o contexto em que está inserida. 
Neste sentido, cabe ressaltar que do ponto de vista da economia local, a exploração da lavra viria de encontro às intenções do Plano Diretor de Desenvolvimento do ramo de atividade, visando dinamizar o mercado de trabalho e aumentar a receita pública. Do ponto de vista das características de uso e ocupação do solo, não se constata qualquer tipo de conflito, uma vez que a área (Serra do Boturuna) onde se localiza a lavra confirma a "vocação" do município para este ramo de atividade. Quanto aos benefícios diretos para a comunidade, pode-se mencionar a geração de empregos que contribuiria sobremaneira para a fixação de população residente no município; portanto, contribuiria para redirecionar a tendência verificada para Pirapora do Bom Jesus de "exportação" de mão-deobra para os municípios do entorno. (JAAKKO, 1989, p. 238).

Conforme descrito, o fato da Serra do Boturuna ser uma ANT não impediu o desenvolvimento de seu potencial minerário. Assim, um dos principais argumentos a favor da exploração minerária da região seria o fato de que as lavras, no caso do empreendimento da Quartzolit, favoreceriam o desenvolvimento sócio-econômico do município. Por isso, o EIA-RIMA propôs que o impacto da atividade nessa esfera de influência é positivo, de pequena magnitude e importância, sendo reversível, pois cessará quando a jazida se esgotar e de média duração, ao considerar a vida útil prevista para 12 anos de exploração. Convém destacar que o documento também menciona o impacto sócio-econômico positivo no município de Jandira, em virtude do beneficiamento do quartzito.

\subsection{5 Área de influência C}

O impacto dessa esfera de influência relaciona-se à geração de empregos diretos e indiretos. Porém, o aumento da mão-de-obra condicionavase à demanda de consumo para o quartzito e para os produtos similares. $\mathrm{A}$ discussão parte do pressuposto que a região e as substâncias minerais extraídas no lavras da Serra do Boturuna podem substituir a areia em alguns usos. Nesse sentido, o quartzito seria considerado um insumo essencial ao desenvolvimento do Estado e do país. Com base nessa análise, o documento apresentou questões relativas sobre a disponibilidade de mão-de-obra e de grandes reservas para a demanda atrelada ao crescimento urbano.

O EIA-RIMA destaca que as areias provêm de quatro tipos principais de jazidas minerais: leito de rios, várzeas (planícies de fluviais), formações sedimentares e de rocha pré-cambriana decomposta. 
O PDM da RMSP indica que as maiores restrições ambientais à exploração das areias relacionam-se as minerações em leito de rios, planícies fluviais e formações sedimentares. Com isso, a exploração do quartzito friável condicionaria um menor impacto ambiental negativo, mas os depósitos de quartzitos na RMSP são muito restritos e localizados, em alguns casos, dentro de áreas protegidas. Por meio da análise conjunta dos fatores, o EIA-RIMA apresenta o seguinte quadro:

- A areia e os agregados similares são insumos básicos para o desenvolvimento do Estado;

- A produção Estadual de quartzito representa 2,8\% da produção Estadual de areia e quartzito conjuntamente;

- O quartzito da Serra do Boturuna tem características tecnológicas ideais para o emprego na fábrica da Quartzolit;

- A produção projetada para as lavras da Quartzolit na Serra do Boturuna representaria, segundo os dados do DNPM na época, $26 \%$ da produção de quartzito registrada para o Estado de São Paulo;

- Diante da produção de quartzito na ocasião, pode-se dizer que as alternativas de fornecimento são limitadas.

Nesse sentido, o EIA-RIMA concluiu que a produção projetada quartzito para a Quartzolit é significativa, mas em relação à produção de areia para o Estado é pouco significativa. Argumentou-se que na ocasião, as alternativas para o fornecimento de quartzito estavam relacionadas à exploração de outras minas na própria Serra do Boturuna, ou em outras formas de jazidas, mas com impactos ambientais negativos, possivelmente, maiores.

A vida útil da jazida possibilitaria à empresa certo tempo para buscar outras fontes de fornecimento de materiais com especificidades técnicas adequadas. Isto proporcionaria o funcionamento normal da indústria, agregaria valor ao quartzito e geraria arrecadação de imposto e empregos, até a substituição da jazida de quartzito por outra frente com todas as licenças cabíveis.

Em função das características do mercado de quartzito, a não implantação da lavra, no entender dos técnicos, teria impacto de significativa magnitude e, possivelmente, ocasionaria um impacto sócio-econômico negativo 
(emprego, geração de impostos), já que a empresa encontraria dificuldade para suprir com os insumos necessários a sua indústria. A importância do empreendimento é praticamente nula, diante das dimensões dos mercados consumidores e da produção de areia como um todo. Porém, o impacto seria reversível, à medida que o quartzito pode ser substituído por outro material (mesmo com maior beneficiamento e geração de rejeitos, como é o caso das areias). Considerou-se um impacto de longo prazo (cinco a dez anos).

\subsection{6 Área de influência D}

O EIA-RIMA considerou como área de influência $D$ os impactos ambientais negativos relacionados ao transporte do minério dentro do Parque Paiol, bairro onde se localiza o empreendimento. Entretanto, este trabalho não pormenorizou essa área de influência por considerar que esse impacto não se relaciona, diretamente, à qualidade ambiental da Serra do Boturuna.

\subsubsection{Proposição de Medidas Mitigadoras}

As medidas mitigadoras também fazem parte do plano de recuperação da área. O relatório destaca que algumas dessas medidas já foram implantadas como a construção da barragem de concreto a jusante da confluência dos córregos Tamanduá e Guamareus (ribeirão Perobas) com o intuito de reter materiais grosseiros (pedra, etc.). No entanto, sugeriram-se também as seguintes medidas: a construção de outra barragem a jusante da primeira; a construção de uma cerca no perímetro da propriedade; e a realização de aceiros rurais para a preservação da propriedade em relação à prática das queimadas na região.

O relatório propôs o aproveitamento da areia represada para evitar o rompimento da barragem ou extravasamento de material por cima da mesma. Segundo o documento, incorporou-se ao projeto o recolhimento e a condução das águas pluviais em canaleta e o posterior lançamento na rede natural de drenagem. Sugeriu-se também a construção de uma barragem, se 
comprovadamente necessária, no córrego Coqueirinho, para a retenção de material, eventualmente, carregado por esse curso d'água e o fechamento do vertedouro da barragem de contenção de finos, durante a operação de dragagem da via sedimentada na bacia de sedimentos para evitar o lançamento de água contendo sólidos.

Estabeleceu-se como medida mitigadora a revegetação das frentes de lavra com capim-gordura (Poaceae - Melinis minutiflora) e a revegetação com essências nativas das lentes de filito aflorante que se configurariam como obstáculos naturais para a redução da velocidade de escoamento superficial das águas pluviais, juntamente com a revegetação com essências nativas das faixas de preservação dos córregos e o plantio de eucalipto no talude a jusante da barragem de terra existente. Segundo o relatório, todas as medidas mitigadoras e os impactos ambientais deveriam ser monitorados.

\subsubsection{PRAD}

O PRAD não definiu um uso para o terreno após a exploração. Esse fato relacionou-se com a configuração final da área lavrada que, segundo a equipe técnica, não permitira qualquer tipo de aproveitamento. Segundo descrito, o Plano buscou alcançar unicamente dois objetivos: harmonia paisagística e minimização dos riscos de erosão. Para isso, constituiu-se, basicamente, do plano de revegetação das áreas lavradas, que visava à reintegração das áreas degradadas à paisagem circundante, além da revegetação das faixas marginais aos cursos d'água e das áreas cujo substrato compunha-se de filito.

A elaboração de um plano de recuperação de áreas degradadas pressupõe a representação da configuração final do pit de lavra. Dessa forma, "O plano de lavra deixa claro que o perfil do morro não sofrerá alteração significativa, apenas um rebaixamento de cerca de cinco metros para todas as cotas." (JAAKKO, 1989, p. 250).

Conforme se descreveu, o contato entre o horizonte alterado e a rocha sã não é regular, assim, prevê-se que os equipamentos de lavra não extrairiam o horizonte alterado completamente, logo, as cavas, na situação final, 
apresentariam um piso aflorante de rocha compacta circundada por rocha decomposta.

Portanto, restará um substrato que, embora pouco erodível devido à pequena quantidade de material friável, torna a tarefa de recomposição paisagística do morro extremamente difícil. A declividade média superior a $40 \%$ torna impossível, o recobrimento da área com uma camada de terra fértil. Assim sendo, a pesquisa para subsidiar a elaboração de um plano de revegetação foi toda voltada para busca de espécies, capazes de colonizar substrato tão adverso. (JAAKKO, 1989, p. 251).

\subsubsection{Plano de revegetação}

O Plano descreve que nas áreas do quartzito friável observou-se a colonização espontânea por capim-gordura (Poaceae - Melinis minutiflora). Explica-se esse aspecto pela sua menor sensibilidade à redução de água disponível no solo, o que poderia explicar em parte sua capacidade de colonização em solos compactos e ou rasos. O capim-gordura é uma espécie indicadora de solos depauperados, como é o caso dos solos na Serra do Boturuna. Outra característica dessa espécie relaciona-se ao fato da possibilidade em dificultar o desenvolvimento de outras espécies. O relatório descreve que há estudos que consideram essa espécie como exótica, mesmo assim, sugeriu-se a sua utilização por sua resistência. Pode-se argumentar que a espécie não é recomendável aos objetivos do tombamento, em virtude de sua inibição para o crescimento das espécies nativas.

De acordo com o Plano, as primeiras espécies a colonizar os afloramentos são as briófitas e pteridófitas. Contudo, o acúmulo de matéria orgânica cria as condições favoráveis à implantação do capim-gordura, espécie dominante no pico da Serra do Boturuna. Há também alguns pontos colonizados por artemísia brava (Ambrosia polytachya), sendo uma espécie considerada daninha infestante de pastos.

O Plano propôs o uso de espécies pioneira, capazes de crescer rapidamente, propiciando condições de microclima favorável ao crescimento de espécies de clímax e o estabelecimento de espécies frutíferas para atraírem dispersores naturais. 
A recomposição da cobertura vegetal baseia-se nos estudos efetuados por Rodrigues ${ }^{32}$ para a Serra do Japi. Assim, no nível de $870 \mathrm{~m}$ propôs-se a predominância da família Myrtaceae (30\% das espécies deveriam ser dessa família). As leguminosas serão utilizadas pela capacidade de fixação de nitrogênio atmosférico.

\subsubsection{Justificativas para a exploração mineral}

O EIA-RIMA, em suas conclusões, fornece os argumentos para justificar a exploração mineral na Serra do Boturuna. Para isso, utilizam-se dois pressupostos: a questão do abastecimento de areia e a recuperação ambiental de uma área que fora degradada e se encontrava abandonada naquele momento.

A decisão de se autorizar a lavra de quartzito friável pela Argamassas QUARTZOLIT Ltda. no Morro do Boturuna, em Pirapora do Bom Jesus, está intimamente ligada a questões complexas, tais como política de abastecimento de areia no Estado de São Paulo e a implementação de mecanismos que assegurem real proteção à área tombada pelo CONDEPHAAT. (JAAKKO, 1989, p. 264).

De acordo com o relatório, o trabalho evidenciou os principais impactos ambientais resultantes do esgotamento do quartzito friável, em relação à situação existente, considerou-se que a mineração na Serra do Boturuna é antiga com frentes de lavra anteriores ao ano 1979, talvez seja anterior a 1976, ou seja, num período sem a necessidade de licenças de instalação da CETESB.

Com relação aos impactos existentes no momento da elaboração do EIA-RIMA, destacou-se que o morro, na vertente norte, está bastante degradado do ponto de vista paisagístico e com o estabelecimento de processos erosivos acelerados. Entretanto, interpretou-se que a continuação da lavra causaria um impacto positivo, pois permitiria o estabelecimento de procedimentos para a redução do problema da erosão e da melhoria das características paisagísticas.

\footnotetext{
${ }^{32}$ RODRIGUES, R. R. Levantamento Florístico e Fiossociológico das Matas da Serra do Japi, Jundiaí - São Paulo. Dissertação (Mestrado). Instituto de Biologia, Universidade Estadual de Campinas. Campinas - SP, 1986. 198 pp.
} 
Se a situação inicial analisada fosse representada por outro segmento da vertente norte, ainda intacto, com sua topografia e cobertura vegetal herbácea preservada, teríamos impactos negativos, mas possivelmente inferiores àqueles registrado em explorações de depósitos de areia de várzeas, de leitos de rios, etc. (JAAKKO, 1989, p. 265).

Ao analisar o abastecimento de agregados para o mercado da construção civil na RMSP, concluiu-se que a exploração de quartzito constituise na opção com menor prejuízo ambiental, opção sugerida inclusive pelo PDM da RMSP.

Quanto à questão do tombamento da Serra, o documento ressalta que as ocorrências de quartzito na RMSP são restritas e a Serra do Boturuna é a área mais explorada na região. "Na porção leste da área tombada, na vertente norte, pouco resta a preservar, já que até mesmo o perfil topográfico foi alterado pela exploração da Mineração Dois Irmãos, que deixou uma 'orelha' no morro." (JAAKKO, 1989, p. 265).

Para o EIA-RIMA, como a política da SMA e do CONDEPHAAT visam a preservação do que resta e recuperar o que já foi degradado, os técnicos sugeriram que os seguintes aspectos deveriam ser contemplados:

- Levantamento, junto ao DNPM, da situação referente aos processos existentes na Serra;

- Verificar em campo a situação que se encontra cada processo;

- Para os processos que ainda dependem de licenças, propor uma negociação em função de um plano de recuperação adequado;

- Para as áreas já degradadas com processos minerários com validade vencida em conseqüência do não cumprimento do Decreto Federal n. 97.888 de 29/06/89 (regulamentado pela portaria de 28/08/89), propôsse que as áreas poderiam ser postas em licitação mediante a apresentação de um PL que contemplasse um plano de recuperação. Neste caso, sugeriu-se também o agrupamento dessas áreas cuja recuperação devesse ser planejada conjuntamente; e

- Para as demais áreas hoje utilizadas como pastos, sugeriu-se a identificação de seus proprietários, para assim, responsabilizá-los por eventuais queimadas.

Em resumo, o EIA-RIMA justifica a necessidade das operações de lavra de quartzito na Serra do Boturuna, pois existe uma grande demanda real e 
reprimida para areia, quartzito e similares. Quando a areia é proveniente de planícies fluviais, a exploração é mais agressiva ao meio ambiente do que a exploração de quartzito friável. O relatório considera que a RMSP possui ocorrências restritas de quartzito. Porém, a Serra do Boturuna possui um histórico de mineração dessa substância mineral e a área já se encontra bastante degradada, tanto por atividades minerárias, quanto por atividade de pecuária extensiva predatória. Ao integrar as características de recuperação ambiental com os aspectos sócio-econômicos, o documento destacou que a Argamassas Quartzolit agrega valor ao quartzito e gera 397 empregos diretos. Ainda segundo o relatório, a remoção do quartzito friável reduziria o potencial de erosão e de assoreamento a jusante da área. "A remoção do quartzito friável provocará alteração da topografia e, conseqüentemente, da paisagem, um impacto que é negativo, embora de pouca magnitude." (JAAKKO, 1989, p. 267).

Para a mineração, a revegetação com essências nativas de área íngremes e margens de cursos d'água reduziria os problemas com a erosão de modo geral, o que contribuiria para a melhoria da qualidade d'água.

A vida útil prevista para a jazida daria tempo à indústria para buscar outras fontes de matéria-prima, bem como para amadurecer um novo projeto de lavra (elaboração de projeto, tramitação de processos junto ao DNPM, SMA, entre outros). O período de exploração da lavra seria suficiente também para que se tente uma solução de menor custo ambiental para o problema do abastecimento de areia das grandes cidades do Estado.

Por meio desses argumentos, o relatório considerou em seu conjunto que os impactos resultantes da lavra de quartzito friável, proposta pela Quartzolit,.são, predominantemente, positivos.

Após a análise da equipe técnica da SMA que solicitou, em 1991, algumas complementações, entre as quais, a identificação dos atuais pontos ou áreas de erosão intensiva, em encostas e na própria área de lavra paralisada e a apresentação de um novo PRAD, uma vez que a SMA, considerou o plano apresentado no EIA-RIMA não satisfatório.

Recomendou-se que o solo do decapeamento seja armazenado para que no final da lavra esse material possa ser utilizado para recobrir o quartzito aflorante e servir como substrato para a vegetação. Esse solo deveria ser 
enriquecido com fertilizantes químicos ou orgânicos antes da semeadura das gramíneas que deveriam ser utilizadas em consórcio com leguminosas e não apenas o capim-gordura como foi proposto no EIA-RIMA. A SMA também solicita a descrição do uso e ocupação do solo futuro da área. Porém a empresa argumentou que:

Como já adiantado no EIA/RIMA, a configuração final da área torna praticamente impossível a definição de usos para o local, principalmente devido à forte declividade natural ocorrente e que será mantida pelo método de lavra proposto, disso resulta que o plano de recuperação deve buscar, em princípio, a harmonia paisagística da área associada ao controle da erosão laminar através de um plano de revegetação. (JAAKKO, 1989, p. 30).

Em 1994, o SMA solicitou uma manifestação da Prefeitura de Pirapora do Bom Jesus quanto à viabilidade do empreendimento com base na legislação de uso do solo do município.

Como resposta, a Prefeitura declarou que, na época, não possuía Lei Municipal de Diretrizes de Uso e Ocupação do Solo, assim, deveriam ser atendidas as diretrizes estabelecidas pela Legislação Estadual e Federal. Quanto ao empreendimento, a Prefeitura não apresentou restrição.

Tudo indica que a Quartzolit não chegou a efetuar exploração comercial em grande escala das frentes de lavras, sobretudo, da poligonal minerária 820.457/1979, assim, as medidas mitigadores do EIA-RIMA não foram totalmente aplicadas e a recuperação da área, proposta pelo PRAD nunca se efetuou.

Destaca-se que o relatório enfatiza os impactos negativos ligados aos recursos hídricos, à jusante da Serra do Boturuna, logo, as medidas mitigadoras e concentram-se nos aspectos relacionados ao assoreamento de cursos d'água. O relatório também não sugere o uso e ocupação do solo futuro da área, sendo uma exigência legal.

A exploração dessas frentes de lavra pela Hipermix, supostamente, condiciona-se ao emprego de grande parte das medidas que constam no plano de recuperação da área apresentado pela Quartzolit, em 1989. No entanto, a Hipermix pretende aumentar as áreas de lavra e explorar o quartzito compacto, o que aumentará ainda mais a degradação ambiental nesse setor da Serra do Boturuna. 


\subsection{MINERAÇÃO ARMANDO ANGELINI}

O PRAD da Mineração Armando Angelini foi elaborado pela UMWELT Consultoria e apresentado à SMA, em junho de 2001. O documento refere-se ao Processo SMA n. 13.616/1999 que envolve a recuperação das áreas onde constam os seguintes Decretos de Lavra: 47.146/59 e 53.208/63. O Plano também complementou o apresentado em 1999, sendo aprovado com algumas exigências.

O PRAD da Armando Angelini possui o intuito de apresentar um diagnóstico ambiental da área de exploração mineral e propor as devidas medidas para a recuperação da área do empreendimento. Tais objetivos pretendiam suprir as necessidades técnicas e legais integrantes do Parecer Técnico CPRN/DAIA n. 03/2000 de 11/01/2000 que reprovou o PRAD apresentado pela mineradora em 1992/1993.

A atividade minerária ocorre na propriedade denominada Sítio Itaqueri, que o Senhor Armando Angelini é co-proprietário. $\mathrm{Na}$ área explorava-se, na época de elaboração do PRAD, principalmente, o quartzito. Essa substância era utilizada como insumo para a construção civil, em especial, para a produção de massa fina. A propriedade total do Sítio Itaqueri é de 363 ha. Porém, as duas poligonais envolvem uma área de 94,42 ha. Na propriedade, desenvolvem-se as frentes de lavras e o beneficiamento do quartzito e do filito.

O Senhor Armando Angelini iniciou a regularização do empreendimento junto ao DNPM, em 1957, por meio do requerimento de pesquisa. Num primeiro momento, esse requerimento se referia à exploração da reserva de dolomito, que correspondia a uma área de 13,57 ha. Contudo, solicitou-se em 1959, o requerimento de pesquisa para a exploração de quartzito e quartzitofilito numa área de 80,85 ha, contígua à primeira área. Deve-se ressaltar que essas substâncias também ocorrem na área onde se solicitou o requerimento de pesquisa para o dolomito. Dessa forma, os processos do DNPM são os seguintes: 6.676/1957 e 854/1959, delimitados no Mapa 17. Esses processos resultaram em distintos Decretos de Lavra. A Mineração Armando Angelini, em 1986, solicitou ao DNPM o agrupamento das poligonais minerárias, esse pedido ainda se encontra em análise, o que demonstra, de certa forma, a morosidade do DNPM. 
De acordo com o Relatório Anual de Lavra (RAL) e com o laudo de vistoria da CETESB, em 2001, a frente de dolomita não estava em atividade.

Como não ocorre a exploração do quartzito puro não se utilizam explosivos para executar a lavra. Nesse sentido, efetua-se a extração dos bens minerais por meio de bancadas de altura variável conforme a seguinte seqüência: decapeamento, escavação, carregamento e transporte para o beneficiamento e/ou expedição do produto.

Segundo o documento, o beneficiamento, que ocorre no local, somente se aplica aos materiais sem especificação para a indústria de massa fina, ou seja, nos rejeitos utilizados como areia para a construção civil. Os procedimentos fundamentais são a lavagem e a classificação granulométrica do material que é disposto em bacia de decantação.

Em 2001, a Mineração Armando Angelini possuía 11 funcionários e, eventualmente, contratava pessoal terceirizado. A produção total comercializada de quartzito, de filito e de areia para a construção civil foi de $86.192,50 \mathrm{~m}^{3}$, o que correspondia a uma produção média mensal de $7.183 \mathrm{~m}^{3}$.

De acordo com o PRAD, as variações granulométricas permitem uma oferta de produtos variados e a velocidade de exploração varia segundo a demanda e as especificações exigidas pelo mercado.

O mercado das substâncias exploradas pela Mineração Armando Angelini encontra-se num raio de $100 \mathrm{~km}$ do empreendimento, sendo constituído por indústrias, pelo comércio de materiais para a construção, por concreteiras, por fábricas de artefatos de concreto e por construtoras.

O relatório descreve que o estabelecimento das diversas frentes de lavra no empreendimento, resulta da irregularidade na demanda dos produtos com características diferenciadas. Assim, com o intuito de ordenar a extração, o que permitiria um melhor aproveitamento dos recursos minerais, o PRAD apresenta no PL uma proposta de setorização geoambiental que determina a manutenção ou fechamento das frentes. O PL indica a manutenção de três frentes de lavra (cava A, cava B e cava C) e de duas áreas de reservas (reserva A e reserva B), a serem exploradas após o fechamento das frentes em atividade, representadas no Mapa 17. 
Mapa 17 - Mineração Armando Angelini Imagem Ortorretificada (2002) e Poligonais Minerárias

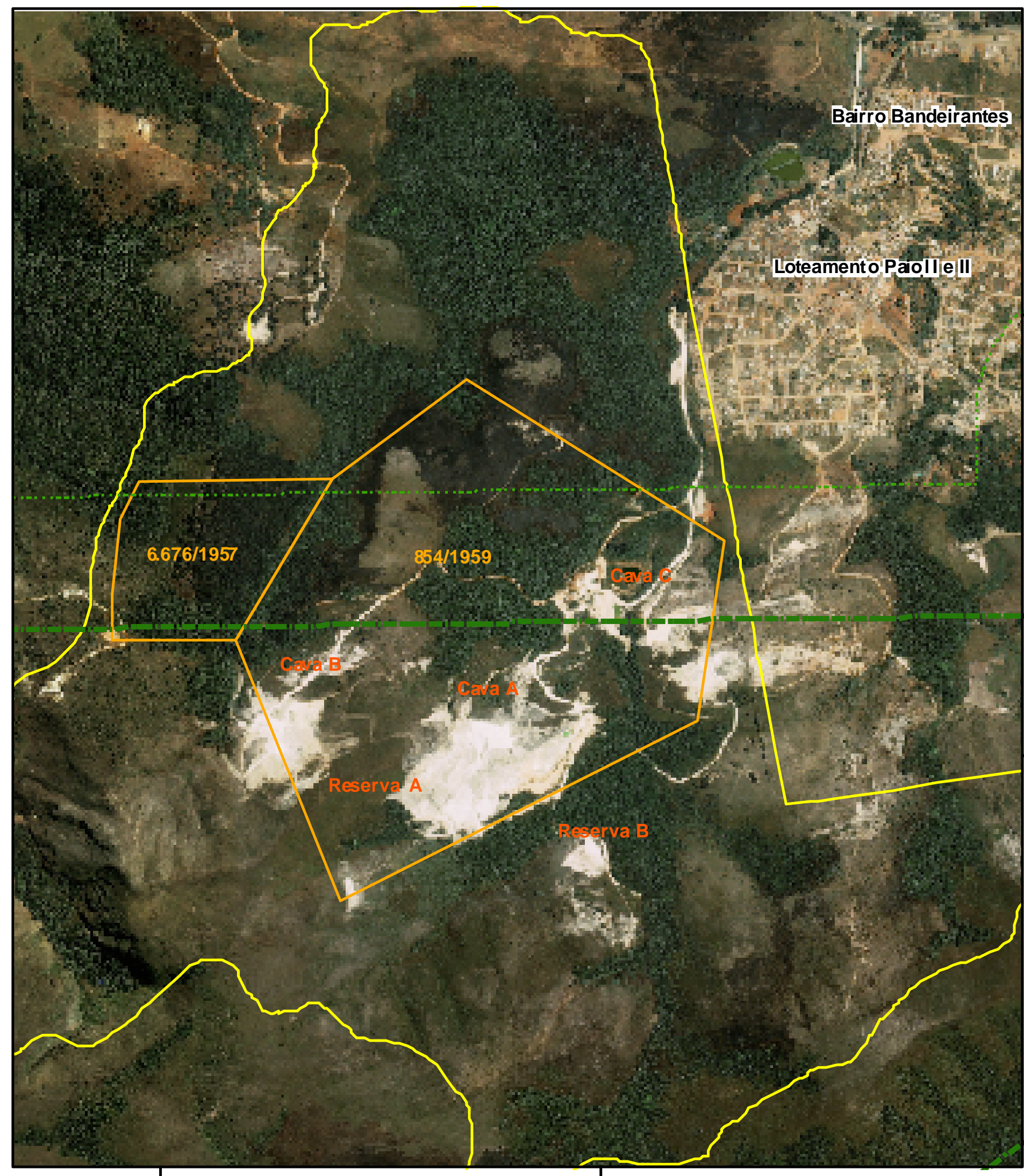

296.000

\section{Legenda}

ANT da Serra do Boturuna

ANT da Serra do Boturuna - $300 \mathrm{~m}$ Poligonais DNPM Limite da Propriedade - Sítio Itaqueri
297.000

Localização na ANT da Serra do Boturuna

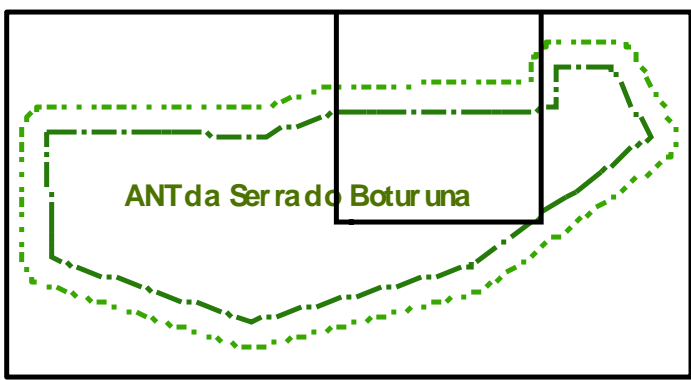

Fonte: DNPM (2008)

Imagens d o Satélite lkonos (PSM, 1m, 2002)

Bab.: Sandro F. Detoni (2008)

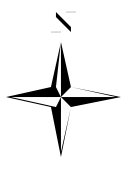

Proje ção Universal Tran versa de Mercator (UTM) Bipsóide: $S A D-69$ Datum Ho rizo ntal: $S A D-69$ Meridiano Central: $45^{\circ} \mathrm{Grw}$.

$1: 12.000$ $\mathrm{km}$

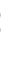


A configuração geométrica das bermas e dos taludes, além dos limites do avanço da lavra foram definidos de acordo com as informações geológicas do local e as restrições técnicas e legais adotadas para a atividade minerária.

Para a mineradora, as medidas propostas têm o objetivo fundamental de minimizar os impactos ambientais negativos causados pelo empreendimento. Entre as medidas principais estão a não interferência em áreas de mata nativa ou secundária em estágios médio ou avançado de regeneração e em APP previstas no Código Florestal.

A lavra de quartzito é executada a céu aberto pelo método de meia encosta e em bancadas únicas em forma de $U$, o que promove 0 estabelecimento de taludes de até $52 \mathrm{~m}$ de altura. O desmonte ocorre por meio de tratores de esteiras equipados com escarificador e lâmina. De forma geral, a desagregação do minério se efetua pelo trator, porém, o procedimento pode ser repetido algumas vezes para a quebra de possíveis blocos remanescentes.

O decapeamento e a lavra das camadas do quartzito se distinguem unicamente por seu destino final, pois enquanto 0 horizonte superficial é estocado em leiras no local, o material lavrado segue para a industrialização. (UMWELT, 2001, p. 26).

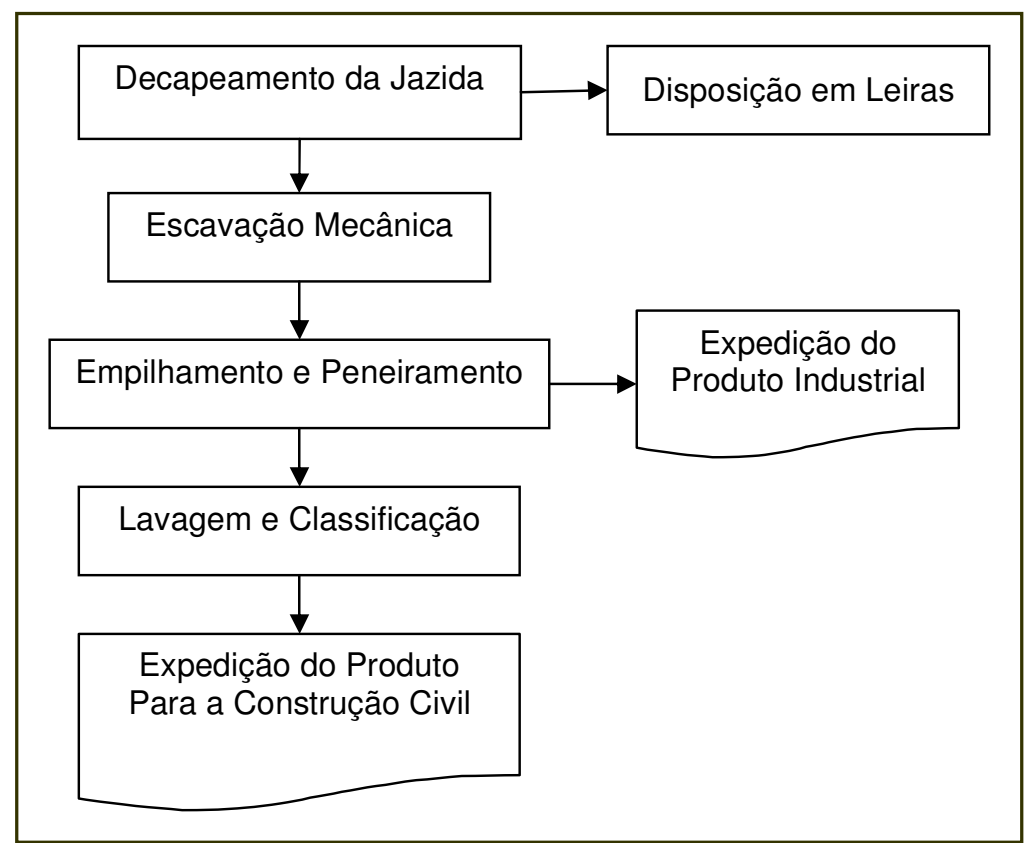

Figura 20 - Organograma do processo de extração mineral (adaptado de WMWELT, 2001)

A Figura 20 apresenta o organograma do processo de extração mineral. Após o desmonte e a desagregação, empilha-se o minério com ajuda de pás- 
carregadeiras sobre pneus. Nessa fase, há um pré-peneiramento com o intuito de separar o minério para ser utilizado na indústria de argamassas, em especial, para a produção de massa fina. Assim, encaminha-se o material que não apresenta a granulometria exigida pelo mercado consumidor para a usina de beneficiamento.

A cava A é a principal frente de lavra da mineradora Armando Angelini. $\mathrm{Na}$ ocasião da elaboração do PRAD, em 2001, essa frente era compreendida entre a cota $814,4 \mathrm{~m}$ até a cota $866,5 \mathrm{~m}$. Em virtude dos aspectos geológicos locais, a exploração dessa lavra ocorre de forma descendente. Procura-se gerar bermas nos atuais taludes a fim de permitir o acesso de equipamentos e o abatimento do ângulo médio de inclinação.

O PRAD apresenta uma planta com a configuração final da lavra. Essa planta descreve a situação prevista para a área lavrada na principal ocorrência de quartzito quando da desativação da mina. Prevê-se uma área plana na cota $800 \mathrm{~m}$ que será circundada de taludes de $20 \mathrm{~m}$ com $60^{\circ}$ de inclinação. Esse talude será intercalado por bermas de quatro metros de largura. $O$ relatório propôs a aplicação das medidas finais de recuperação, quando a configuração lavra apresentar uma situação de estabilidade geotécnica. A Tabela 38 apresenta as reservas lavráveis da mineração. Destaca-se o volume de reserva lavrável da cava A, principal frente de lavra e onde se estabelecem os maiores impactos negativos na paisagem da Serra do Boturuna.

Não se estabelece a tipologia de uso futuro da área, o PRAD somente menciona que a área estará apta a uma utilização futura definida pelo proprietário, juntamente com o poder público. 
Tabela 38 - Mineração Armando Angelini: reservas laváveis medidas/indicadas In Situ*

\begin{tabular}{|c|c|c|}
\hline Setor & Substância Mineral & Volume $\left(\mathrm{m}^{3}\right)$ \\
\hline Cava A & Quartzito e Quartzito-Filito & 2.618 .554 \\
\hline Cava B & Quartzito-Filito e Filito & 831.049 \\
\hline Cava C & Quartzito e Quartzito-Filito & 67.255 \\
\hline Reserva A & Quartzito-Filito & 2.050 .541 \\
\hline Reserva B & Filito & 446.600 \\
\hline \multicolumn{2}{|c|}{ Reserva Total Medida/Indicada } & 6.013 .999 \\
\hline
\end{tabular}

Fonte: UMWELT (2001)

*Definidas segundo as configurações geométricas previstas no PRAD

O documento estimou um volume estimado de estéril de $49.702 \mathrm{~m}^{3}$, que corresponde uma relação estéril/minério de 1/121. Tais dados demonstram uma baixa relação. Entretanto, como premissa de cálculo, considerou-se que $50 \%$ das ocorrências já estavam decapeadas e que a espessura do capeamento é de apenas $0,5 \mathrm{~m}$. O PRAD também faz uma ressalva em relação ao aproveitamento do minério. De acordo com o Plano, em torno de $10 \%$ do minério explorado é formado por rochas e por material não aproveitável, o que eleva o volume total de estéril em, aproximadamente, $646.132 \mathrm{~m}^{3}$.

Com base na produção média mensal de $7.183 \mathrm{~m}^{3}$, o tempo para a exaustão das jazidas, em 2001, seria de, aproximadamente, 69,8 anos. Porém, - PRAD descreve que o potencial das reservas, dentro dos limites dos Decretos de Lavra, é superior ao apresentado no Plano de Lavra (PL).

O PRAD propôs que o total de material inerte (por volta de $650.000 \mathrm{~m}^{3}$ ) seja aproveitado na recuperação nas áreas degradas ou depositado na porção inferior da cava $A$ e na futura cava de mineração da reserva $B$.

A previsão de utilização da porção inferior da cava $A$, que será preenchida com material estéril, é de $689.513 \mathrm{~m}^{3}$, ou seja, a expectativa de material inerte gerado nas operações de desmonte é suficiente para o preenchimento da Cava A.

Os outros materiais gerados no processo produtivo, tais como os rejeitos da usina de beneficiamento, serão dispostos em bota-fora. Assim, prevê-se a criação de um aterro de $60.700 \mathrm{~m}^{3}$ e $45^{\circ}$ de inclinação com bermas intercaladas, de forma subhorizontal de cinco metros de largura. Nessas 
bermas serão instaladas canaletas longitudinais e escadas hidráulicas, juntamente com a plantação de gramíneas por hidrossemeadura.

O documento apresenta, para as cavas A, B e C, plantas de detalhe que propôs o aproveitamento da situação topográfica e o melhor potencial da jazida com uma situação final de encosta na forma de anfiteatros. Para o PRAD, tal procedimento reduz o impacto negativo na paisagem.

\subsubsection{Medidas mitigadoras}

As medidas mitigadoras adotadas ou propostas para suprimir ou minimizar os efeitos inerentes à atividade relacionam-se aos seguintes impactos: controle da emissão de particulados, que alteram a qualidade do ar no decorrer do processo minerário, emissão de gases por veículos automotores, geração de ruídos na execução de lavra e alteração da rede de drenagem, da alteração topográfica, supressão da cobertura vegetal, efeitos sobre a fauna, geração de resíduos sólidos, geração de fluentes líquidos e alteração no tráfego de veículos.

A atividade de exploração mineral, embora potencialmente agressiva ao meio ambiente, desempenha papel de fundamental importância sócio-econômica, à medida que é fornecedora de insumos básicos para a indústria de transformação e matérias primas para a construção civil, além de gerar empregos diretos e indiretos (UMWELT, 2001, p. 39).

O PRAD reconhece que a degradação ambiental é inerente à atividade. Todavia, apresenta algumas propostas generalistas para minimizar os efeitos negativos ao meio ambiente que envolve os aspectos relacionados à constituição da lavra.

As intervenções necessárias para a continuidade do presente empreendimento fazem com que a interferência ambiental seja um fator inerente a atividade, entretanto, seus efeitos ambientais podem ser minimizados ou evitados, através da previsão de técnicas adequadas no planejamento da atividade e na recuperação dos eventuais danos ambientais. (UMWELT, 2001, p. 39).

A alteração topográfica produz efeito direito nos objetivos de proteção da ANT da Serra do Boturuna. Porém, o PRAD pressupõe que a tal alteração é inevitável. "Os impactos ambientais decorrentes dos movimentos de terra e do perfil final do terreno deverão ser considerados permanentes e irreversíveis" (UMWELT, 2001, p. 44). 
A medida mitigadora refere-se à disposição final da topografia local por meio do confinamento da frente de lavra. $O$ documento sugere que tal confinamento faz com que o empreendimento não apresente impacto visual significativo ao seu entorno, logo, a disposição final do empreendimento absorverá as modificações permanentes na topografia ocasionadas pela atividade de mineração. Assim, a principal medida mitigadora relaciona-se a implantação de barreira vegetal com espécies de rápido crescimento, que atenuará, segundo o PRAD, o possível impacto visual junto à divisa da propriedade com o loteamento Paiol I e II.

Os impactos negativos na paisagem gerados pela frente de lavra e a conseqüente desconfiguração topográfica serão estabilizados por meio do retaludamento das cavas e o plantio de espécies vegetais. Entretanto, observou-se na visita de campo, que o emprego de tal procedimento é, extremamente, dificultado, em virtude do nível de degradação ambiental atual. A forma de execução da lavra em meia encosta, apresentadas na Figura 20, não permite o retaludamento completo da cava ${ }^{33}$. Juntam-se a isso, as altas declividades da Serra que dificultam o estabelecimento dos solos e da vegetação.

O documento afirmou que a supressão da cobertura vegetal não implicará em impactos significativos ao ambiente local, pois não há espécies arbóreas nas áreas de expansão da mineração, apenas gramíneas com reduzida diversidade de espécies. Logo, considerou-se o impacto ambiental como de pequenas proporções, permanente, mas reversível, ao relevar que as áreas serão recuperadas por meio de plantio heterogêneo de espécies nativas. Devido à baixa densidade de vegetação, o Plano concluiu que os efeitos sobre a fauna são de proporções mínimas, assim, o Plano sugere a interligação dos fragmentos florestais existentes na propriedade.

\footnotetext{
${ }^{33} \mathrm{~A}$ mineradora não permitiu a visita às frentes de lavra.
} 


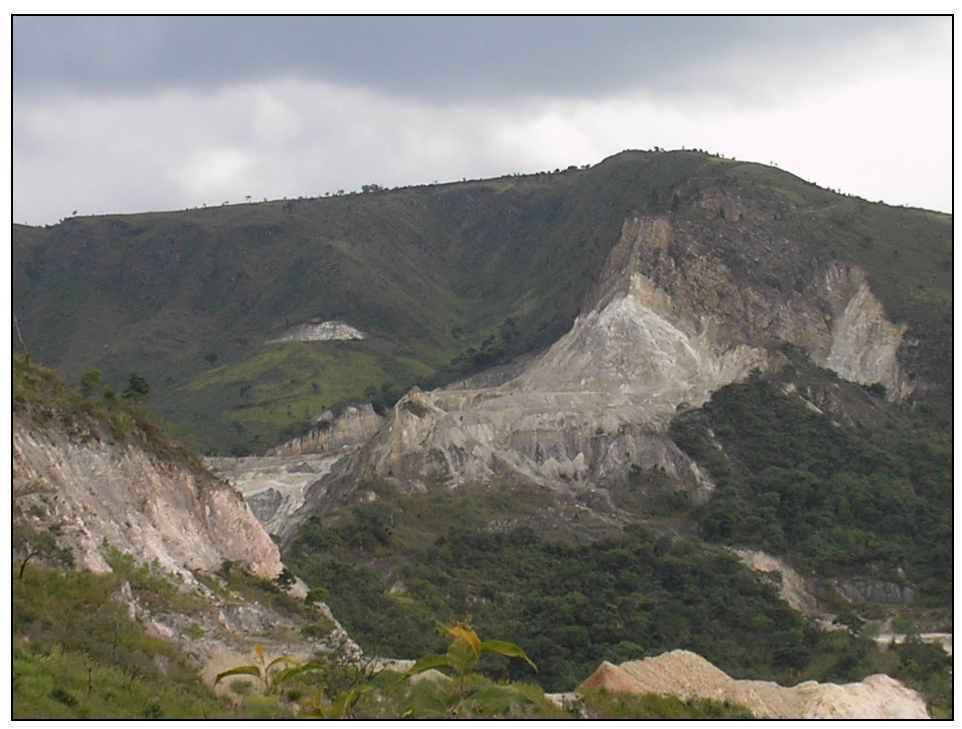

Figura 21 - Cava A da Mineração Armando Angelini (Sandro F. Detoni, maio de 2008)

O PRAD menciona que parte da área do Sítio Itaqueri foi englobada pelo tombamento da Serra do Boturuna e faz menção que, segundo o art. $6^{\circ}$. da resolução de tombamento, esse instrumento jurídico não interfere nas atividades de mineração. Entretanto, como parte dos procedimentos necessários de regularização ambiental, na ocasião da elaboração do PRAD e conforme as solicitações da SMA, a mineração procurou obter um manifesto específico formal do CONDEPHAAT sobre a localização do empreendimento no perímetro da ANT. Segundo o documento, além das consultas informais, encaminharam-se três ofícios ao órgão (em 29/10/1996, em 28/07/2008 e em 04/04/2001). Esses ofícios fazem parte dos anexos do PRAD e não consta nenhum pronunciamento formal deste egrégio Conselho em resposta as solicitações.

\subsubsection{Plano de recuperação da área}

O Plano tem como pressuposto estabelecer um novo equilíbrio dinâmico, sobretudo nas frentes de lavra. A equipe técnica efetuou um diagnóstico local dos impactos ambientais por meio da foto-interpretação e do trabalho de campo, que identificaram os principais processos de alteração das características naturais da área. Esse procedimento teve como base a proposição de medidas de caráter preventivo e corretivo para conter, 
sobretudo, as seguintes formas de degradação: erosão laminar, erosão em sulcos, ravinamentos, concentração de fluxo, solapamento, disposição de material terroso, supressão da vegetação e intervenção em APP.

A erosão laminar ocorre em superfícies expostas, sem cobertura vegetal. O Plano recomenda a proteção dessas superfícies por meio do plantio de gramíneas. Para a erosão em sulcos e ravinamento propôs-se a regularização do terreno mediante a utilização de técnicas de corte e recomposição com solo compactado e plantio de gramíneas. A concentração de fluxo decorre do desvio das águas superficiais das frentes de lavra, devido à alteração da topografia local e ao direcionamento do escoamento. As medidas de recuperação propostas envolveram a implantação de um sistema de drenagem superficial: canaleta, valeta e escadas d'água para conduzir o fluxo à drenagem natural. $\mathrm{O}$ solapamento relaciona-se ao movimento de materiais nas margens dos cursos d'água. O Plano indica a recomposição vegetal dessas áreas com gabiões ou enroncamento laçado, seguido da recuperação vegetal com o plantio de grama em placas na superfície do terreno a montante dos locais recuperados.

As medidas para conter o assoreamento da rede de drenagem natural referem-se ao tratamento das águas pluviais, que incluem a construção de caixas de retenção de finos, dissipadores de energia e recuperação das áreas sem cobertura vegetal, além de finalizar o sistema de bacias de decantação.

Com relação à disposição do material terroso, o PRAD estabelece que o material excedente seja disposto em bota-foras, seguido pelo processo de regularização do terreno e pela reconstituição da cobertura vegetal.

Segundo o PRAD e o PL da jazida, não haverá desmatamentos nas frentes de lavra. Entretanto, indicam-se algumas medidas relacionadas à supressão de vegetação ocorrida na propriedade, caracterizadas por serem medidas de caráter corretivo e preventivo. De forma geral, consistem em recobrir as superfícies com gramíneas, leguminosas arbustivas e ou essências nativas arbóreas, juntamente com o desenvolvimento de projetos de plantio heterogêneo nas áreas desativadas e que tiveram sua cobertura natural erradicada para a execução da lavra.

Áreas recobertas por campos antrópicos e com grande potencial de conectividade ente os fragmentos florestais mais avançados também deverão ser objeto de implantação de plantio heterogêneo. Tal medida apresente caráter compensatório às intervenções ocorridas ao longo do processo de implantação do empreendimento com 
apropriação de algumas áreas de preservação permanente (APP), principalmente na região da usina de beneficiamento. (UMWELT, 2001, p. 65).

As intervenções nas APPs serão compensadas por meio da implantação de um sistema de drenagem (galerias) de forma que a água (intermitente e perene) seja conduzida ao seu curso habitual. Nas margens dos cursos d'água será efetuado o plantio de gramíneas, leguminosas arbustivas e a revegetação com espécies nativas.

\subsubsection{Diretrizes para a recuperação da cobertura vegetal}

O Plano propõe que as espécies vegetais arbóreas utilizadas na revegetação sejam de ocorrência natural na região. Nesse tópico, destaca-se que a utilização futura pré-estabelecida para a propriedade será como reserva e abrigo da fauna silvestre.

Nos taludes existentes nas áreas recuperadas, que possuem alta instabilidade geotécnica, recomendou-se a utilização de gramíneas exóticas com alta rusticidade e rápido crescimento, para a contenção dos processos erosivos.

Espera-se, ainda, que os fragmentos de vegetação nativa, a médio e longo prazo, contribuam para a colonização de espécies nas áreas recuperadas. O documento também apresenta algumas especificações técnicas com relação ao plantio e a origem das mudas, assim como o preparo do solo.

\subsubsection{Medidas compensatórias}

As medidas compensatórias referem-se às interferências em APP e ou às supressões da cobertura vegetal que foram necessárias para 0 desenvolvimento das lavras. O Plano indica um projeto de plantio compensatório numa área de, aproximadamente, dois ha, distribuídos próximo ao limite da propriedade com a Mineradora Minarca.

Segundo o relatório, o objetivo principal dessa medida consiste no enriquecimento da cobertura vegetal da área do sítio e a recuperação das 
áreas desprovidas de cobertura vegetal nativa próximo aos fragmentos florestais. Tais fragmentos foram identificados, sobretudo, na porção sul do sítio, ou seja, na face norte da Serra do Boturuna e na própria área de recomposição ambiental contígua a cava C. Ao sul desse setor, segundo o Plano, a recomposição, além de recobrir e proteger o solo, em longo prazo, constituirá contínuos ecológicos de fragmentos florestais com o intuito de criar as condições vegetacionais pretéritas.

\subsubsection{Avaliação final}

Como avaliação final, o PRAD ressalta a existência de alguns impactos ambientais causados, sobretudo, pela falta de orientação técnica, pois se trata de um empreendimento antigo. Segundo o Plano, tais impactos não são causados pela indiscriminada forma de exploração do meio natural, prova disso são os fragmentos de vegetação de porte que, ainda, existem dentro das poligonais ativas. Assim, as medidas propostas são corretivas, mitigadoras e permitirão uma ordenação da lavra, bem como a recuperação de áreas desativadas. $\mathrm{O}$ documento sugere que as medidas contribuirão para a melhoria do cenário ambiental, principalmente, pela interligação dos fragmentos florestais existentes.

A proposição de um plantio compensatório na porção $S$ da propriedade permitirá a recomposição vegetal de parte da Serra do Boturuna, que aliado às ações de recuperação das áreas degradadas, totalizará grandes ganhos de superfície a ser recoberta com espécies vegetais nativas, dentro de área protegida por Tombamento do CONDEPHAAT, o que significa tratar-se de plantio definitivo sem possibilidades de corte, aumentando mais ainda sua importância. (UMWELT, 2001, p. 87).

O PRAD enfatiza que a degradação ambiental nas vertentes do setor norte da Serra do Boturuna ocorreu, principalmente, pela retirada da cobertura vegetal, num período anterior à atividade de mineração. Nesse sentido, justifica-se que a mineração constitui na solução para a recuperação ambiental da área. Apesar dos impactos ambientais negativos na paisagem local, relacionados à execução da lavra, as formas de recuperação prevêem, prioritariamente, medidas compensatórias que pautam no estabelecimento de 
cobertura vegetal em campos degradados e a interligação dos fragmentos florestais existentes.

A hipótese de que a mineração contribui para a recuperação ambiental da região fica clara na conclusão do PRAD, no qual, destaca-se que as medidas apresentadas no Plano e sua respectiva aplicação trarão ganhos para a cobertura vegetal, pois aumentará a superfície recoberta com espécies vegetais nativas, dentro de área protegida por tombamento pelo CONDEPHAAT. Tal hipótese possui, conforme o foco de análise, certo fundamento. Porém, o tombamento da Serra do Boturuna não ocorreu somente por suas características vegetacionais. O relevo, que possui destaque na paisagem regional, apresenta-se como um dos principais atributos do tombamento. Logo, a solução técnica apresentada pelo PRAD, ou seja, a construção das bermas e dos taludes, provavelmente, não contribuirá para a harmonia paisagística da região, sobretudo pelo método de execução da lavra. Tal característica compromete o cumprimento do art. $7^{\circ}$. da resolução de tombamento da Serra: "As explorações ilegais, assim como aquelas comprovadamente lesionantes e desfigurantes, serão proibidas e automaticamente desativadas."

Ressalta-se que a execução de uma lavra de quartzito, por si só, causa um sensível impacto negativo na paisagem. A empresa mineradora reconhece tal impacto ambiental, porém, conforme o método de lavra e o grau de exploração dos recursos minerais, o impacto pode ser potencializado.

A mineração executa a lavra em meia-encosta e de forma descendente. Esse aspecto relaciona-se, sobretudo, à segurança na frente de lavra. No entanto, se os trabalhos de lavra fossem concentrados somente no sopé da Serra ou em cotas altimétricas inferiores, possivelmente, o impacto visual na paisagem seria menor e preservaria, até certo ponto, o conjunto paisagístico da Serra. Entretanto, tais medidas dependem da segurança da frente de lavra e dos aspectos econômicos envolvidos na exploração.

A proposição de medidas de recuperação das áreas degradadas, referente à exploração em meia-encosta, possui seus condicionantes atrelados à alta declividade e à espessura do perfil de solo, pois dificultam o estabelecimento dos taludes e das bermas. Por isso, interpreta-se que o padrão paisagístico não se ajustará aos objetivos do tombamento. Deve-se 
destacar que tais interpretações necessitam de um maior embasamento técnico e de um estudo mais aprofundado das características litológicas na região.

No contexto geral, o plano de recuperação das áreas degradadas pela Mineração Armando Angelini, também reforça a idéia da importância secundária que o relevo possui na recuperação ambiental dos setores da Serra do Boturuna.

A degradação da paisagem nesse setor da ANT ainda será intensa, em virtude da exploração das reservas existentes que se encontram nas maiores altitudes da Serra. Contribui para isso, o estabelecimento de reservas fora da área das poligonais minerárias e a exploração que extrapolou o perímetro indicado nessas poligonais.

\section{CONSIDERAÇÕES FINAIS}

A região da Serra do Boturuna constitui-se numa importante área de remanescentes florestais da RMSP. Sua estrutura paisagística e seus aspectos paleogeográficos e paleoclimáticos fornecem importantes justificativas a sua preservação. Ao considerar os aspectos naturais da Serra, entende-se que o seu tombamento ocorreu de forma adequada. Os objetivos previstos na resolução de tombamento condizem com a importância em preservar dois atributos fundamentais: a vegetação e, sobretudo, a estrutura topográfica da Serra. Entretando, a fragilidade ambiental da Serra, em virtude de seus solos ácidos e pobres em nutrientes, também se constitui num argumento favorável ao ato de tombamento. Deve-se ressaltar que as propriedades físico-químicas dos solos influenciaram na distribuição da vegetação dentro do macrocompartimento geomorfológico no qual a Serra se inclui, logo, as

características geomorfológicas, pedológicas e litológicas dificultam o restabelecimento espontâneo da cobertura vegetal, quando suprimida.

Alguns setores da Serra do Boturuna passaram por um intenso processo de desmatamento, por isso, torna-se de suma importância criar determinados instrumentos de preservação e de conservação dos remanescentes florestais 
existentes, que cumprem distintos papéis no controle ambiental e no armazenamento de estoques biológicos.

A importância ambiental da Serra do Boturuna confronta com a exploração do seu potencial minerário. No âmbito jurídico, a atividade minerária contraria os dispositivos básicos para a manutenção da tipologia de espaço protegido que se insere a Serra. Contudo, os mineradores destacam a importância da mineração e apresentam os planos de recuperação das áreas degradadas como a alternativa viável para a melhoria da qualidade ambiental de uma região historicamente degradada por essa atividade.

Os aspectos históricos que envolveram a formação sócio-econômica de Pirapora do Bom Jesus e de Santana de Parnaíba influenciaram, de forma fundamental, sobre as particularidades referentes à preservação da Serra do Boturuna. A região, que se constituiu como um importante centro minerador, nunca possuiu um retorno econômico significativo por tal atributo. As substâncias exploradas nesses territórios possuem baixo valor de mercado, sendo empregadas, sobretudo, na construção civil. Essa característica também favoreceu a ilegalidade da atividade.

Santana de Parnaíba, com seu centro histórico, relativamente preservado, desenvolveu sua base econômica em distintos setores, entre os quais, o industrial, próximo à Rodovia Anhangüera. O condomínio Alphaville também contribuiu para o impulso econômico do setor de serviços no município. A diversidade econômica e as imposições de ordem técnica à exploração mineral, possivelmente, contribuíram para a preservação ambiental das vertentes da Serra do Boturuna na região.

O crescimento urbano de Santana de Parnaíba se orientou para outros núcleos e a principal atividade de exploração mineral do município encontra-se na Serra do Itaqui. Na região da Serra do Boturuna, localiza-se o condomínio Voturuna e algumas chácaras de lazer. Assim, a Serra nunca se constituiu, efetivamente, como um recurso mineral a ser explorado e as bases ambientais para a sua preservação se encontram bem consolidadas no município.

Pirapora do Bom Jesus, sem perspectivas no setor agropecuário, devido, principalmente, à configuração de seu relevo, desenvolveu o setor turístico e o minerário. O desenvolvimento do setor minerário, que já ocorrera desde meados do século XIX, apresentou um significativo crescimento a partir 
da metade do século XX. Na década de 1980, o município se tornou um dos principais produtores de quartzito da RMSP, logo, a exploração dessa substância se concentrou, sobretudo, na Serra do Boturuna.

O CONDEPHAAT ponderou o fato, na ocasião do tombamento da Serra, que a atividade de exploração mineral, possuía relativa importância para o município. A mineração era um dos principais geradores de empregos, tanto na etapa de extração como no beneficiamento. O IUM da época também era responsável por uma importante parcela da receita municipal.

Com o intuito de se evitar um confronto jurídico junto aos mineradores, o ato de tombamento permitiu a continuidade das explorações minerárias na Serra. Tal medida contrariou os dispositivos básicos das legislações de tombamento. No caso da Serra do Boturuna, o objetivo principal desse instrumento jurídico de proteção foi o de garantir a preservação dos atributos naturais da Serra, logo, a exploração mineral, possivelmente, não contribuiria para isso. Assim, a resolução, apesar de hábil em permitir a atividade mineral na região e evitar o conflito jurídico com os mineradores, apresentou-se contraditória aos seus objetivos. Para tentar amenizar os efeitos dessa disposição, o instrumento jurídico propôs um controle da atividade por meio da ação conjunta entre o DNPM e o CONDEPHAAT e, até mesmo, das prefeituras municipais. Verificou-se que tal controle nunca ocorreu, ora por falta de empenho e morosidade do DNPM, ora pelas dificuldades técnicas do CONDEPHAAT.

Para a recuperação da cobertura vegetal, o instrumento jurídico do tombamento apresentou bons resultados. Demonstra-se essa hipótese por meio dos dados sobre a evolução do uso e da ocupação do solo no período após o tombamento. Contudo, destaca-se que o aumento da cobertura vegetal foi maior em Santana de Parnaíba. Em Pirapora do Bom Jesus, esse aumento evidencia-se pela preservação de alguns remanescentes de vegetação e pelo aumento das matas ciliares.

Sem dúvida, o principal problema ambiental nessa ANT é a mineração, que resulta na desconfiguração topográfica da Serra e ocasiona um sensível impacto ambiental negativo. No entanto, somente o mercado de minerais pode indicar qual o limiar de exploração dos recursos minerais das frentes de lavra 
da região, enquanto as reservas não se exaurirem, pois a resolução de tombamento não impôs maiores restrições à atividade.

Após o estabelecimento da ANT, a significância econômica da exploração mineral na Serra do Boturuna para Pirapora do Bom Jesus diminuiu, mas não deixou de ser importante. O retorno financeiro, em termos de impostos, dessas explorações é inferior ao repasse de ICMS ecológico, referente à ANT da Serra do Boturuna e à ANT do Japi, para o município. Assim, a mudança para uma categoria de conservação mais restritiva poderia aumentar o repasse do ICMS para o município. Mesmo com pouca participação na receita municipal, o ICMS ecológico pode ser uma alternativa ao CFEM, imposto repassado aos municípios pela exploração dos recursos minerais em seu território. Com isso, a diminuição do setor minerário não refletiria num impacto negativo às receitas municipais.

Se, na ocasião do tombamento, a Serra possuía importante contribuição nas reservas e na produção de alguns bens minerais, observou-se que a busca por esses recursos minerais se diversificou espacialmente no Estado. Porém, a exploração da Serra do Boturuna, ainda contribui com parcelas significativas da produção de quartzito.

$\mathrm{Na}$ análise dos planos de recuperação das áreas degradadas pela atividade minerária, constatou-se que o enfoque principal desses relatórios estava na recuperação da vegetação pelo plantio direto nas frentes lavra ou nas medidas de compensação ambiental que incluíram, sobretudo, a recuperação da mata ciliar. A recuperação topográfica apresentou-se como uma medida secundária. Assim, os planos confirmaram a incompatibilidade de uma mineração com um dos objetivos do tombamento: a preservação da topografia. No contexto geral, a alteração topográfica resultante do tipo de minério explorado é inevitável, inclui-se também que as medidas técnicas de recuperação possuem alto custo e dependem de um planejamento inicial das explorações.

Destaca-se que apenas duas mineradoras propuseram o uso futuro das áreas de mineração: a Lolli e a Minarca. A proposta da Lolli encontra base legal na resolução de tombamento. Porém, sugere-se o aperfeiçoamento do projeto, pois há itens incompatíveis com os objetivos do tombamento. Já a Minarca, que possui grande parte das frentes de lavra na zona de amortecimento de 
$300 \mathrm{~m}$, com o intuito da obtenção de um retorno financeiro, estabeleceu o uso futuro como um loteamento residencial urbano. No entanto, verificou-se que a mineradora não cumpriu o cronograma de recuperação e a situação da área, atualmente, é de completo abandono com incidência de processos erosivos nas frentes de lavra abandonadas.

$\mathrm{Na}$ Serra do Boturuna, observa-se também o avanço de algumas frentes de lavra fora do limite das poligonais requeridas junto ao DNPM. Isso demonstra a falta de planejamento, de controle e de fiscalização do setor.

Com relação à aplicabilidade das medidas sugeridas pelos planos de recuperação, apesar de alguns resultados positivos, sobretudo, na recomposição da cobertura vegetal, estima-se que o tipo de exploração mineral empregada, dificilmente, permitirá um quadro paisagístico favorável, pois compromete um dos principais atributos do tombamento: a topografia da Serra.

No caso da Serra do Boturuna, qualquer plano de recuperação ou intervenção no ambiente deveria considerar os atributos fundamentais que justificaram o seu tombamento. Torna-se importante também ponderar sobre a presença da ANT no planejamento do uso e ocupação do solo do seu entorno.

A atividade de mineração numa ANT contraria os preceitos jurídicos desse instrumento de preservação. De certa forma, a resolução de tombamento tentou compatibilizar a atividade mineração com a preservação dos atributos ambientais da Serra. A questão envolve aspectos técnicos que uma resolução não consegue abranger. Por isso, torna-se muito importante que os instrumentos jurídicos de preservação ambiental sejam acompanhados de ações conjuntas de planejamento ambiental e setorial. Caso contrário continuará havendo meia mineração e meia Serra do Boturuna. 


\section{REFERÊNCIAS}

AB'SÁBER, A. N. Parecer do Projeto de Urbanização da Fazenda da llha, Municípios de Embu-Guaçu e São Paulo. São Paulo: EMPLASA, 1978. (Exigência EMPLASA 37/78).

Parecer Técnico Para o Tombamento da Serra do Boturuna. In: Estudo do Tombamento da Serra do Boturuna (habitualmente chamada de Voturuna) em Santana de Parnaíba. São Paulo: CONDEPHAAT, 1982.

. A Serra do Japi, Sua Origem Geomorfológica e a Teoria dos Refúgios. In: MORELLATO, P. C. (Org.). História Natural da Serra do Japi: Ecologia e Preservação de Uma Área Florestal do Sudeste do Brasil. Campinas, SP: Editora da UNICAMP/FAPESP, 1992. p.12-23.

Os Domínios de Natureza no Brasil: Potencialidades Paisagísticas. São Paulo: Ateliê Editorial, 2003. 159 p.

. São Paulo: Ensaios e Entreveros. São Paulo: Editora da Universidade de São Paulo/ Imprensa Oficial do Estado de São Paulo, 2004.

ALMEIDA, F. F. M.de Fundamentos Geológicos do Relevo Paulista. São Paulo: Instituto de Geografia da USP, 1974. 99 p. Série Teses e Monografias, 14

ALMEIDA, F. F. M de; HASUI, Y.; NEVES, B. B. B. The Upper Precambrian of South America. São Paulo: Instituto de Geociências da USP, 1976. Boletim IG, V.7: 45-80.

BERTRAND, G. Paisagem e Geografia Global: Esboço Metodológico. São Paulo: Instituto de Geografia da USP, 1971. 23 p. Caderno de Ciências da Terra, 43. Tradução: CRUZ, O. 
CAMARGO, MONS. P. F. da S. História de Santana de Parnaíba. São Paulo: Conselho Estadual de Cultura, 1971, 372 p.

CHRISTOFOLETTI, A. Análise de Sistemas em Geografia. São Paulo: HUCITEC/EDUSP, 1979.

CONDEPHAAT - Conselho de Defesa do Patrimônio Histórico, Arqueológico e Turístico do Estado de São Paulo. Estudo do Tombamento da Serra do Boturuna (habitualmente chamada de Voturuna) em Santana de Parnaíba. (Processo n. 22328/82). São Paulo: CONDEPHAAT, 1982.

COUTINHO, J. M. V. Petrologia do Pré-Cambriano de São Paulo e arredores. São Paulo: Instituto de Geociências da USP, 1972. Boletim IG, V.3: 5-99.

DNPM - Departamento Nacional de Produção Mineral. Anuário Mineral Brasileiro. Brasília: DNPM, 1972. V.1. (V.31 - 2002; V.32 - 2003; V.33 - 2004; V.35-2005; V.36-2006).

EMPLASA - Empresa Paulista de Planejamento Metropolitano. Plano Diretor de Mineração Para a Região Metropolitana de São Paulo: Diagnóstico e Diretrizes. São Paulo: DNPM/Secretaria de Estado dos Negócios Metropolitanoa (SNM)/EMPLASA, 1980.

Plano Diretor de Mineração Para o Município de Pirapora do Bom Jesus. São Paulo: Secretaria de Estado dos Negócios Metropolitanoa (SNM)/EMPLASA, 1982.

Plano Diretor de Mineração Para o Município de Santana de Parnaíba. São Paulo: Secretaria de Estado dos Negócios Metropolitanoa (SNM)/EMPLASA, 1985.

Mapa de Uso e Ocupação do Solo da Região Metropolitana de São

Paulo e Bacia do Alto Tietê (2002). São Paulo: EMPLASA, 2005. 
FERRI, M. G. Uma Década (1968-1977) de Trabalhos no Cerrado. In: GOODLAND, R.; FERRI, M. G. (Orgs.) Ecologia do Cerrado. Belo Horizonte, MG: Editora Itatiaia; São Paulo: EDUSP, 1979.

FRANÇA, M. C. Pirapora do Bom Jesus, Centro Religioso do Alto Tietê. Boletim Paulista de Geografia, São Paulo, n. 41, 1964.

- Pequenos Centros Paulistas de Função Religiosa. São Paulo: Instituto de Geografia da USP, 1975. 418 p., 2 v., Série Teses e Monografias, 12.

GOODLAND, R. Análise Ecológica da Vegetação do Cerrado. In: GOODLAND, R.; FERRI, M. G. (Orgs.) Ecologia do Cerrado. Belo Horizonte, MG: Editora Itatiaia; São Paulo: EDUSP, 1979.

HACKSPACHER, P. C.; GODOY, A.M.; OLIVEIRA, M.A.F. Evolução Crustal do Bloco São Roque, na Região Sudeste do Estado de São Paulo. Revista Brasileira de Geociências, São Paulo, v. 23, 1993.

HASUI, Y. Evolução Polifásica do Pré-Cambriano a Oeste de São Paulo. São Paulo: Instituto de Geociências da USP, 1975a. Boletim IG, V.6: 95-108.

. Geologia da Folha São Roque. São Paulo: Instituto de Geociências da USP, 1975b. Boletim IG, V.6: 157-183.

HASUI, Y; SADOWSKI, G. R.; CARNEIRO, C. D. R. Considerações Sobre a Estratigrafia do Pré-Cambriano na Região de São Paulo. São Paulo: Instituto de Geociências da USP, 1976. Boletim IG, V.7: 107-112.

HASUI, Y.; SOARES, A. A. T. L.; CSORDAS, S. M. Geologia e Tectônica da Serra do Japi. São Paulo: Instituto de Geociências da USP, 1978. Boletim IG, V.9: $17-24$. 
IBGE - Instituto Brasileiro de Geografia e Estatística. Mapa de Vegetação do Brasil. IBGE: 2004.

IPT - Instituto de Pesquisas Tecnológicas do Estado de São Paulo. Mapa Geomorfológico do Estado de São Paulo: Escala: 1: 500.000. São Paulo: Secretaria da Indústria, Comércio, Ciência e Tecnologia do Estado de São Paulo (SICCT)/ Programa de Desenvolvimento de Recursos Minerais (PróMinério)/ Companhia de Promoção de Pesquisa Científica e Tecnológica do Estado de São Paulo (PROMOCET), 1981.

. Geologia da Folha Santana de Parnaíba: Escala 1: 50.000 (SF-23-YC-III-3). São Paulo: Secretaria da Indústria, Comércio, Ciência e Tecnologia do Estado de São Paulo (SICCT)/ Programa de Desenvolvimento de Recursos Minerais (Pró-Minério), 1984. (Relatório Número 20767 - Volume 1)

JAAKKO Pöyry Engenharia Ltda. Relatório de Impacto Ambiental Lavra de Quartzito: Argamassas Quartzolit Ltda. São Paulo: Jaakko Pöyry Engenharia Ltda., 1989. V. I, II e III.

JULIANI, C. O Embasamento Pré-Cambriano da Bacia de São Paulo. Problemas Geológicos e Geotécnicos na Região Metropolitana de São Paulo. São Paulo: ABAS/ABGE/SBG-SP, 1992.

KNECHT, T. Ocorrências Minerais do Estado de São Paulo. São Paulo: Instituto Geográfico e Geológico (IGG)/Secretaria da Agricultura, 1950. Vol. I. Municípios de São Paulo, Santana de Parnaíba, Barueri, Franco da Rocha, Guarulhos, Mogi das Cruzes, Suzano e Poá.

LEINZ, V. AMARAL, S. E do. Geologia Geral São Paulo: Editora Nacional, 1998. 13 ed. rev. 399 p.

LEITÃO-FILHO, H. de F. A Flora Arbórea da Serra do Japi. In: MORELLATO, P. C. (Org.). História Natural da Serra do Japi: Ecologia e Preservação de 
Uma Área Florestal do Sudeste do Brasil. Campinas, SP: Editora da UNICAMP/FAPESP, 1992. p.40-63.

LOCATELLI, M. Publicação eletrônica [mensagem pessoal]. Mensagem $<$ recebida por mtlocatelli@terra.com.br> em 04 set. 2008.

LOLLI Extrativa de Minerais Ltda. Plano de Recuperação de Áreas Degradadas. São Paulo: Lolli Extrativa de Minerais, Ltda., 2004. (Processo CETESB n. 320573/94, Processo SMA n. 13.610/02)

MACHADO, P. A. L. Direito Ambiental Brasileiro. 12 ed. São Paulo: Malheiros Editores, 2004. 1.075 p.

MAGNANI, J. G. C. Santana do Parnaíba: Memória e Cotidiano. São Paulo: Cedac, 1984. 113 p.

MONTEIRO, C. A. de F. A Frente Polar Atlântica e as Chuvas de Inverno na Fachada Sul-Oriental do Brasil (Contribuição metodológica à análise rítmica dos tipos de tempo no Brasil). São Paulo, 1969. Instituto de Geografia da USP. Série Teses e Monografia Nº. 168 p.

A Dinâmica Climática e as Chuvas no Estado de São Paulo: Estudo Geográfico sob Forma de Atlas. São Paulo. Instituto de Geografia, Universidade de São Paulo, 1973. 130 p.

MORELLATO, P. C. Sazonalidade e Dinâmica de Ecossistemas Florestais na Serra do Japi. In: MORELLATO, P. C. (Org.). História Natural da Serra do Japi: Ecologia e Preservação de Uma Área Florestal do Sudeste do Brasil. Campinas, SP: Editora da UNICAMP/FAPESP, 1992. p.98-112.

OLIVEIRA, J. B. et at. Mapa Pedológico do Estado de São Paulo: Legenda Expandida - Escala 1:500.000. Campinas, SP: IAC/EMBRAPA, 1999. 
PINTO, H. S., ORTOLANI, AA. ALFONSI, RR. Estimativa das Temperaturas Médias Mensais do Estado de São Paulo Em Função da Altitude e Latitude. São Paulo, 1972. Instituto de Geografia da USP. Caderno Ciências da Terra, 23. 20 p.

POLETTO, C. A Exploração de Pedreiras na Região Metropolitana de São Paulo no Contexto do Planejamento e Gestão do Território. Tese (Doutorado em Geografia Humana). Departamento de Geografia, FFCH, USP. São Paulo, 2006. 276 p. Fig.

ROMARIZ, DORA de A. Reconhecimento de Alguns Padrões de Vegetação nas Áreas das Bacias Hidrográficas Referentes às Represas Billings e Guarapiranga. Boletim Paulista de Geografia, São Paulo, n. 22, 1956.

ROSS, J. L. S. ; MOROZ, I. C. Mapa Geomorfológico do Estado de São Paulo. Laboratório de Geomorfologia. São Paulo: Departamento de Geografia - FFLCH - USP/Laboratório de Cartografia Geotécnica - Geologia Aplicada - IPT/FAPESP (Fundação do Amparo à Pesquisa do Estado de São Paulo), 1997. (Mapas e Relatórios)

ROSS, J. L. S. Registro Cartográfico dos Fatos Geomórficos e a Questão da Taxonomia do Relevo. Revista do Departamento de Geografia da USP, São Paulo, n. 6, p. 17-29, 1992.

- Análise Empírica da Fragilidade dos Ambientes Naturais e Antropizados. Revista do Departamento de Geografia da USP, São Paulo, n. 8, p. 63-74, 1994.

- Superfícies de Erosão ou Erosão Química nos Processos de Esculturação dos Planaltos do Leste Paulista. Revista Geosul da UFSC, Florianópolis, SC, v.14, n.27, p. 688-691, 1998.

Geomorfologia: Ambiente e Planejamento. São Paulo: Ed. Contexto, 2001. 85 p. 
SAINT-HILAIRE, A. de. Viagem à Província de São Paulo. Belo Horizonte, MG: Editora Itatiaia; São Paulo: EDUSP, 1976. 229 p.

SAMPAIO, T. O Tupí na Geographia Nacional. 3 ed. Bahia: Escola de Aprendizes Artífices, 1928. 352 p.

SÃO PAULO, ESTADO. Secretaria de Estado do Meio Ambiente. Meio Ambiente: Instrumentos Econômicos e Financeiros. Série: Meio Ambiente. São Paulo: Secretaria do Meio Ambiente, 1998. 263 p.

. Secretaria de Estado do Meio Ambiente. Inventário Florestal da Vegetação Natural do Estado de São Paulo. São Paulo: Secretaria de Estado do Meio Ambiente/Instituto Florestal, 2005. 200 p.

- Secretaria da Indústria, Comércio, Ciência e Tecnologia. Mapa de Jazidas e Ocorrências Minerais do Estado de São Paulo. São Paulo: Secretaria da Indústria, Comércio, Ciência e Tecnologia/Programa de Desenvolvimento dos Recursos Minerais (Pró-Minério)/Companhia de Promoção de Pesquisa Científica e Tecnológica do Estado de São Paulo (PROMOCETI), 1981.

- Secretaria de Estado do Meio Ambiente. Relatório de Qualidade Ambiental no Estado de São Paulo. São Paulo: Secretaria de Estado do Meio Ambiente, 2007.

SILVA, J. B. ANDRADA e; ANDRADA, M. F. R. Viagem Mineralógica na Província de São Paulo (Primeira Parte). Boletim Paulista de Geografia, São Paulo, n. 16, 1954.

SILVA, M. A. R. Publicação eletrônica [mensagem pessoal]. Mensagem $<$ recebida por rezende@srnet.com.br> em 11 set. 2008. 
SONDA Serviços de Geotecnia S/C Ltda. Plano de Recuperação de Áreas Degradadas pela Minarca Indústria, Comércio e Mineração Ltda. São Paulo: Sonda Serviços de Geotecnia S/C Ltda., 2004. (Processo SMA n. 13.732/2004)

UMWELT Consultoria. Plano de Recuperação de Áreas Degradadas Pela Mineração Armando Angelini. São Paulo: UMWELT Consultoria, 2001. (Processo SMA n. 13.616/1999)

UNESCO - United Nations Educational, Scientific and Cultural Organization. Internation Classification, and Mapping of Vegetation. E. Trilingüe. Série "Ecology and Conservation" n. 6: Paris, 1973. 


\section{ANEXOS}

ANEXO A - Resolução da Secretaria de Cultura n. 17 de 04 de agosto de 1983 - Conforme Processo CONDEPHAAT n. 22328/82 (TRANSCRIÇÃO)

JOÃO PACHECO E CHAVES, SECRETÁRIO EXTRAORDINÁRIO DA CULTURA, no uso de suas atribuições legais e nos termos do Artigo $1^{\circ}$ do Decreto-Lei $n^{\circ}$. 149, de 15 de agosto de 1969 e do Artigo 143, § $1^{\circ}$., do Decreto $n^{\circ}$. 13.426, de 16 de março de 1979 ,

\section{RE S O L VE}

Artigo 1‥ - Fica Tombada a SERRA DO BOTURUNA, destacado monte quartzítico, parcialmente florestado, situado entre Santana de Parnaíba e Araçariguama (1.175-1.278m). O Tombamento se faz para proteger a pequena serra como acidente geológico e topográfico, dotado de solos pobres, densas florestas de encostas frágilmente implantadas, recursos hídricos representados por torrentes radiais, e, remanescentes representativos da flora e da fauna regional, que dão ao Boturuna o caráter de refúgio forçado da natureza tropical na região.

Artigo $2^{\circ}$. - A área de Tombamento envolve um pequeno polígono, grosso modo orientado de este para oeste, contendo um eixo maior de $6.900 \mathrm{~m}$ (comprimento), por um eixo menor de $2.300 \mathrm{~m}$ (largura, envolvendo terras dos Municípios de Santana de Parnaíba, Pirapóra do Bom Jesus e do Distrito de Araçariguama. Inclui-se simbolicamente ao Tombamento, como anexo importante, setor da linha do Trópico de Capricórnio que se estende desde a intersecção dessa coordenada com a Rodovia Castelo Branco até $6.000 \mathrm{~m}$ para leste. O polígono que delimita a área nuclear de Tombamento é delimitado por 10 pontos, cujas coordenadas, estabelecidas em cartas topográficas do antigo Instituto Geográfico e Geológico do Estado de São Paulo, na escala de 1:50.000, estão representadas na tabela e no mapa, anexos.

Artigo 3o. - O Tombamento da Serra do Boturuna se circunscreve ao acidente topográfico principal, sua cobertura vegetal e torrentes radiais, tendo em vista a necessidade de garantir a preservação de seus patrimônios 
ambientais, bióticos e paisagísticos. Os patamares e colinas que a partir da meia-serra baixa envolvem a Serra, ficam excluídos da área de Tombamento senso stricto, permanecendo numa faixa de $300 \mathrm{~m}$ sob um discreto critério de controle de organização espacial, por parte do CONDEPHAAT.

Artigo 4․ - Projetos turísticos bem elaborados vinculados ao Programa de "Áreas Especiais e Locais de Interesse Turístico" da Embratur, feitos com todas as precauções inerentes ao paisagismo ecológico, compatíveis com padrões corretos de preservação - a critério do CONDEPHAAT - poderão ser estudados para sítios paisagisticamente relevantes no interior e margens da área tombada, em setores não florestados, de declives mais suaves, e, sempre fora das áreas de cabeceiras de mananciais.

Artigo 5o. - Fica prevista a possibilidade de implantação de pequenas bases para pesquisa científicas, parques estaduais e ou municipais, de área restrita, em glebas localizadas em terras devolutas ou desapropriadas na Serra ou em seus arredores imediatos. Os estudos desenvolvidos pelos pesquisadores especializados (botânicos, zoólogos e ecologistas), nas bases de pesquisas previstas para o Boturuna e outros deverão contribuir para orientar o CONDEPHAAT na sua política de preservação da natureza regional.

Artigo 60. - Os mineradores que tenham autorização do D.N.P.M. para lavra de produtos minerais do subsolo, em suas respectivas - propriedades, e que tenham estabelecimentos tradicionais no ramo de mineração, e, sensibilidade comprovada ou comprovável na preservação dos espaços físicos e ecológicos da Serra do Boturuna e seu entorno imediato, poderão continuar a desenvolver tais atividades, normalmente.

Artigo 7ํ. - Fica estabelecido no Ato de Tombamento da Serra do Boturuna, que todos os casos de atividades de extração mineral, não abrangidos neste documento, serão resolvidos pro acordos diretos entre o D.N.P.M. e o CONDEPHAAT, através de um Grupo de Trabalho a ser organizado, ouvido os interessados, e com parecer terminal do Conselho. As explorações ilegais, assim como aquelas comprovadamente lesionantes e desfigurantes, serão proibidas e automaticamente desativadas.

Artigo 8․ - As áreas devolutas, por ventura existentes no interior do espaço do Tombamento, serão motivo de considerações especiais entre o 
CONDEPHAAT, a Procuradoria do Patrimônio Imobiliário Geral do Estado, e as respectivas Prefeituras Municipais da região.

Artigo 9․ - As áreas em disputa judicial ou objetos de processos de usucapião ficarão sob responsabilidade da Procuradoria Geral do Estado, reservando-se o CONDEPHAAT o direito de orientar o processo eventual de reciclagem de tais espaços para fins de lazer comunitário.

Artigo 10 - Não serão toleradas quaisquer instalações industriais na área de Tombamento e de seu entorno imediato (faixa de $300 \mathrm{~m}$ a partir dos limites da área tombada). Identicamente é vedado a instalação de qualquer núcleo de carvoaria nestas áreas. Madeiras retiradas de glebas de silvicultura, deverão ser trabalhadas fora do núcleo principal da área de Tombamento.

Artigo 11 - Nesse Ato de Tombamento fica prevista a criação de um "Conselho de Moradores" e de uma "Comissão" inter-órgãos-públicos para controle da organização do espaço, ordenação dos processos e revisão periódica da conjuntura da preservação da natureza, na região da Serra do Boturuna.

Artigo 12 - Fica o Conselho de Defesa do Patrimônio Histórico, Arqueológico, Artístico e Turístico do Estado de São Paulo autorizado a inscrever no Livro do Tombo competente a área em referência para os devidos efeitos legais.

Artigo 13 - Esta Resolução entrará em vigor na data de sua publicação.

Transcrito do Diário Oficial 
ANEXO B - Brasões Municipais que Representam a Serra do Boturuna
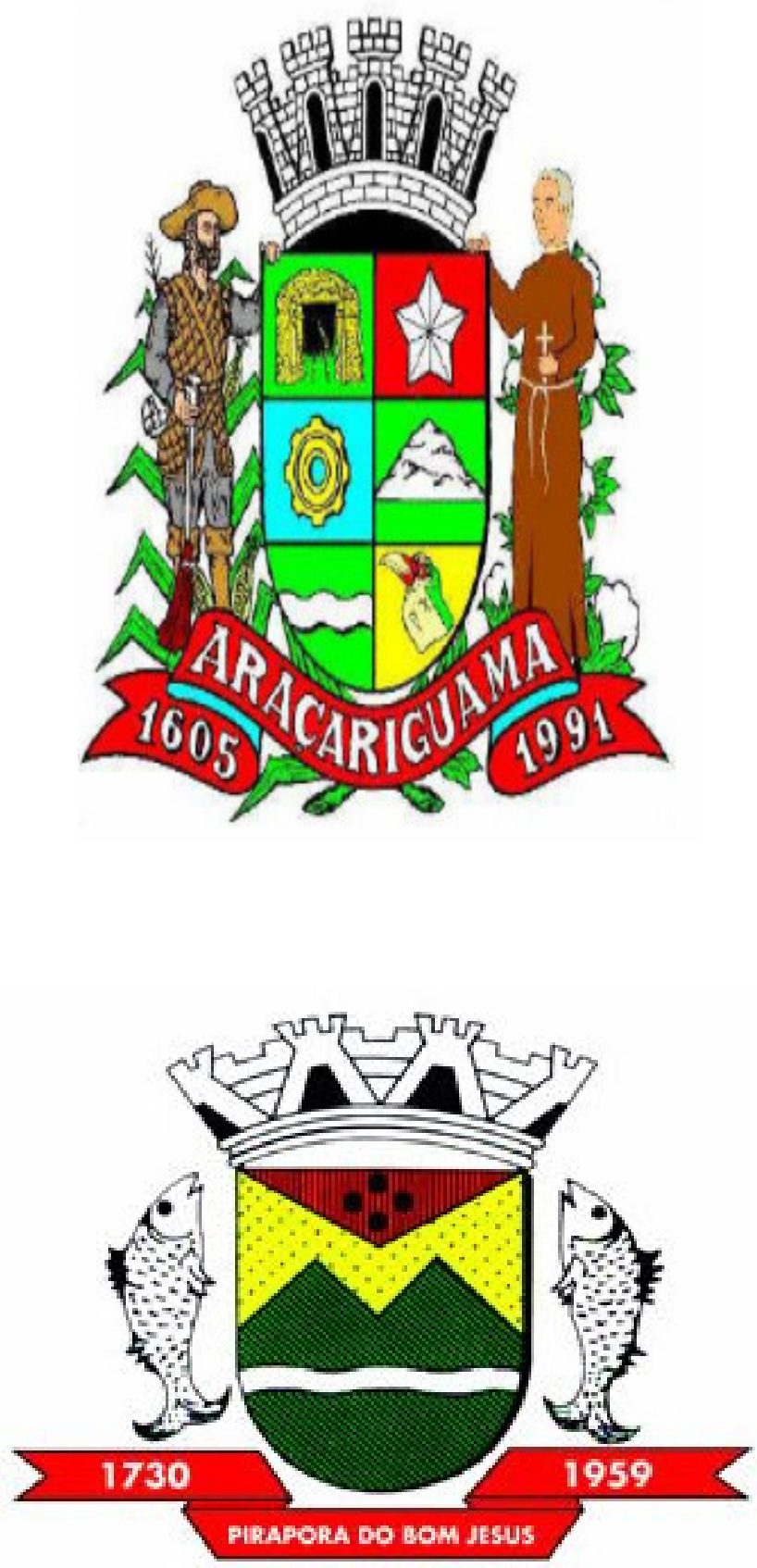